\title{
Supporting Information: Understanding the Reactivity and Decomposition of a Highly Active Iron Pincer Catalyst for Hydrogenation and Dehydrogenation Reactions
}

Julia B. Curley, ${ }^{\mathrm{a}, \mathrm{Il}}$ Nicholas E. Smith, ${ }^{\mathrm{a}, \mathrm{Il}}$ Wesley H. Bernskoetter, ${ }^{\mathrm{b}}$ Mehmed Z. Ertem, ${ }^{\mathrm{c}}$ Nilay Hazari, ${ }^{\mathrm{a}, *}$ Brandon Q. Mercado, ${ }^{\mathrm{a}}$ Tanya M. Townsend, ${ }^{\mathrm{a}}$ and Xiaoping Wang ${ }^{\mathrm{d}}$

${ }^{a}$ The Department of Chemistry, Yale University, P. O. Box 208107, New Haven, Connecticut, 06520, USA. E-mail: nilay.hazari@ yale.edu.

${ }^{b}$ The Department of Chemistry, The University of Missouri, Columbia, Missouri, 65211, USA. ${ }^{\mathrm{c} C h e m i s t r y ~ D i v i s i o n, ~ B r o o k h a v e n ~ N a t i o n a l ~ L a b o r a t o r y, ~ U p t o n, ~ N e w ~ Y o r k ~ 11973-5000, ~ U S A . ~}$

${ }^{\mathrm{d}}$ Neutron Scattering Division, Oak Ridge National Laboratory, Oak Ridge, Tennessee 37831, USA.

"Denotes that the authors made equal contribution.

I. General Methods

II. Synthesis of 6 and 7

III. Protonation of 1 with Acids Containing a BAr ${ }_{4}$ Counterion and Reactions of the Resulting Solution

IV. Synthesis of 8 in situ, $T_{1}$ Determination, and HD Adduct Spectrum

V. Synthesis of $\left({ }^{i P r} P N^{H} P\right) F e$ Dimers 11 and 12

VI. Reaction of 6 with 1

VII. Titration of 1 with 2,6-lutidinium $B A r^{F}{ }_{4}$ for $p K_{a}$ Determination

VIII. Experiments to Probe Phosphine Binding

IX. Formic Acid Dehydrogenation Details

$X$. NMR and IR Spectra for New Compounds

XI. Van't Hoff Plot for the Addition of $\mathrm{H}_{2}$ to 1

XII. X-ray Crystallographic Information

Details about the structure of 5- $\mathrm{N}_{2}$

Details about the structure of $5-\mathrm{H}_{2} \mathrm{O}$

Details about the structure of 7

Details about the structure of 8

Details about the structure of $\mathbf{1 1}$

Details about the structure of $\mathbf{1 2}$

XIII. Single Crystal Neutron Diffraction

$X I V$. Computational Details and Coordinates

$X V$. Discussion on Dissociative CO Loss from ${ }^{i P r} P N^{H} P$ Supported Fe complexes

$X V I$. References
S2

S3

S5

S12

S16

S18

S19

$\mathrm{S} 20$

S22

S27

S51

S53

S53

S55

S57

S59

S60

S61

S64

S66

S142

S153 


\section{General Methods}

Experiments were performed under a dinitrogen atmosphere in an M-Braun glovebox or using standard Schlenk techniques unless otherwise noted. Under typical operating conditions, the glovebox was not purged between uses of benzene, diethyl ether, pentane, THF, or toluene. As a consequence, each solvent should be assumed to contain trace amounts of the others. All moisture and air-sensitive liquids were either transferred inside the glovebox or using a stainless-steel cannula on a Schlenk line. Solvents were dried by passage through a column of activated alumina and stored under dinitrogen unless otherwise noted. Ethanol (200 proof) was purchased from Decon Laboratories, Inc., and degassed and stored under dinitrogen prior to use. All commercial chemicals were used as received except where noted. $\left.{ }^{\mathrm{iPr} P N P}\right) \mathrm{Fe}(\mathrm{H})(\mathrm{CO})(\mathbf{1})^{1}$ and $\left({ }^{\mathrm{iPr}} \mathrm{PN}^{\mathrm{H}} \mathrm{P}\right) \mathrm{Fe}(\mathrm{H})(\mathrm{CO})(\mathrm{OC}(\mathrm{O}) \mathrm{H})(\mathbf{1 0})^{1}$ were prepared according to literature procedures. 2,6-lutidinium hexafluorophosphate was prepared via salt metathesis from 2,6-lutidinium chloride and $\mathrm{KPF}_{6}$ in ethanol, ${ }^{2}$ and Brookhart's acid $\left(\mathrm{HBAr}_{4}{ }_{4}\right)$ was prepared via protonation of $\mathrm{NaBAr}_{4} \mathrm{~F}_{4}$ with commercially available ethereal $\mathrm{HCl}^{3}$ Tetrabutylammonium cyanide and anhydrous HD were purchased from Sigma Aldrich. Anhydrous $\mathrm{H}_{2}$ was purchased from Airgas, Inc. Anhydrous $\mathrm{D}_{2}$ was purchased from Cambridge Isotope Laboratories. $\mathrm{C}_{6} \mathrm{D}_{6}$, THF- $d_{8}$, and $\mathrm{C}_{6} \mathrm{D}_{5} \mathrm{CD}_{3}$ were purchased from Cambridge Isotope Laboratories and dried by passage through a plug of activated alumina. NMR spectra were recorded on Bruker AMX-400, AMX500 or AMX-600, spectrometers at ambient probe temperatures unless otherwise noted. Chemical shifts are reported in ppm ( $\delta$ ) with respect to residual internal protio solvent for ${ }^{1} \mathrm{H}$ and ${ }^{13} \mathrm{C}\left\{{ }^{1} \mathrm{H}\right\}$ NMR spectra. ${ }^{19} \mathrm{~F}$ and ${ }^{31} \mathrm{P}\left\{{ }^{1} \mathrm{H}\right\}$ NMR spectra are referenced via the ${ }^{1} \mathrm{H}$ resonances based on the relative gyromagnetic ratios. ${ }^{4}$ All $J$ coupling constant values are given in Hertz. Elemental analyses were performed by Robertson Microlit Laboratories, Inc. Solid state infrared data were obtained on a Bruker ALPHA FTIR spectrometer with a platinum ATR attachment inside a $\mathrm{N}_{2}$-filled glovebox. Solution state data were obtained using a PIKE solution cell $1 \mathrm{~mm}$ attachment. Gas Chromatography was performed on a ThermoFisher Trace 1300 GC apparatus equipped with a thermal conductivity detector and a Supelco fused silica capillary column (5 $\AA$ molecular sieves, $30 \mathrm{~m} \mathrm{x} 0.53 \mathrm{~mm}$ ). He carrier gas was used for determination of $\mathrm{CO}_{2}$ and $\mathrm{CO}$ at concentrations greater than $1 \mathrm{ppm}$. 


\section{Synthesis of 6 and 7}

Synthesis of ( $\left.{ }^{\left({ }^{P r} \mathbf{P N}\right.}{ }^{\mathrm{H}} \mathbf{P}\right) \mathbf{F e}(\mathbf{H})(\mathbf{C O})\left(\mathbf{P F}_{6}\right)(6)$ : In a vial, $\mathbf{1}$ (68.1 mg, $\left.0.175 \mathrm{mmols}\right)$ was dissolved in THF (5 $\mathrm{mL})$. To this, a solution of 2,6-lutidinium hexafluorophosphate (131.6 mg, 0.520 mmols) in THF (5 mL) was added, causing an immediate color change from dark red to orange. The volatiles were then removed in vacuo. The crude orange solid was extracted with benzene $(10 \mathrm{~mL})$ and pentane $(10 \mathrm{~mL})$ was added, causing the product to precipitate. The supernatant was decanted and the recrystallization procedure repeated to yield 6 as an orange solid (yield: $50.6 \mathrm{mg}, 54 \%) .{ }^{1} \mathrm{H}$ NMR $\left(500 \mathrm{MHz}, \mathrm{C}_{6} \mathrm{D}_{6}, \delta\right): 4.16$ (br, $1 \mathrm{H}$, $\mathrm{NH}$ ), 3.29 (br, 2H, $\mathrm{CH}_{2}$ ), 1.66-2.01 (br m, $\left.10 \mathrm{H}, \mathrm{CH}_{2}, \mathrm{CH}\left(\mathrm{CH}_{3}\right)_{2}\right), 0.72-1.15$ (br m, $24 \mathrm{H}$, $\left.\mathrm{CH}\left(\mathrm{CH}_{3}\right)_{2}\right),-16.45(\mathrm{br}, 1 \mathrm{H}, \mathrm{Fe} H) .{ }^{31} \mathrm{P}\left\{{ }^{1} \mathrm{H}\right\}$ NMR $\left(202 \mathrm{MHz}, \mathrm{C}_{6} \mathrm{D}_{6}, \delta\right): 91.8\left(\mathrm{~s},{ }^{\mathrm{i} P} P \mathrm{~N}^{\mathrm{H}} P\right),-135.8\left(\mathrm{br}, P \mathrm{~F}_{6}\right)$. ${ }^{19} \mathrm{~F}$ NMR $\left(471 \mathrm{MHz}, \mathrm{C}_{6} \mathrm{D}_{6}, \delta\right):-75.98$ (br). Solutions of $\mathbf{6}$ were not stable long enough to reliably acquire a ${ }^{13}$ C NMR spectrum. IR (solid-state, $\mathrm{cm}^{-1}$ ): $3274\left(\mathrm{U}_{\mathrm{NH}}\right), 1942\left(\mathrm{U}_{\mathrm{CO}}\right)$. Elemental analysis was not obtained due to the instability of the sample.

Synthesis of $\left[\left({ }^{\text {Prr }} \mathbf{P N}{ }^{\mathrm{H}} \mathbf{P}\right) \mathbf{F e}(\mathbf{H})(\mathbf{C O})\left(\mathbf{P M e}_{3}\right)\right]\left[\mathbf{P F}_{6}\right]$ (7): A Schlenk flask was charged with $\mathbf{1}$ (37.2 mg, 0.0956 mmols) and 2,6-lutidinium hexafluorophosphate (24.4 mg, $0.0964 \mathrm{mmols})$ and THF (10 mL), generating an orange solution of $\mathbf{6}$. To this, one equivalent of $\mathrm{PMe}_{3}(9.25 \mu \mathrm{L}, 0.0909$ mmols $)$ was added by syringe. Upon stirring, the solution immediately turned pale yellow. The reaction was allowed to stir for five minutes, after which the solution was concentrated to a volume of approximately $5 \mathrm{~mL}$. To this, $10 \mathrm{~mL}$ of pentane was added, causing a white solid to precipitate. The supernatant was filtered off, yielding $\mathbf{7}$ as a white powder (yield $38.8 \mathrm{mg}, 70 \%$ ). Single crystals were grown at room temperature in $\mathrm{C}_{6} \mathrm{D}_{6}$ in a J Young tube. The orientation of the $\mathrm{PMe}_{3}$ ligand relative to the N-H moiety was determined to be $s y n$ by $2 \mathrm{D}{ }^{1} \mathrm{H}$ NOESY NMR (500 ms mixing time). The spectra are included below. Anal. Found (calc'd) for $\mathrm{C}_{20} \mathrm{H}_{47} \mathrm{~F}_{6} \mathrm{FeNOP}_{4}$ : C, 39.40 (39.29); H, 7.91 (7.75); N 2.29 (2.29). ${ }^{1} \mathrm{H}$ NMR (400 MHz, THF-d8, $\delta$ ): 3.39 (br m, 3H, NH and $\left.\mathrm{CH}_{2}\right), 2.59\left(\mathrm{~m}, 2 \mathrm{H}, \mathrm{CH}_{2}\right), 2.38-2.52\left(\mathrm{~m}, 3 \mathrm{H}, \mathrm{CH}_{2}\right), 2.33\left(\mathrm{~m}, 2 \mathrm{H}, \mathrm{CH}_{2}\right), 1.94(\mathrm{~m}, 2 \mathrm{H}$, $\left.\mathrm{CH}_{2}\right), 1.78\left(\mathrm{~m}, 4 \mathrm{H}, \mathrm{CH}\left(\mathrm{CH}_{3}\right)_{2}\right), 1.51\left(\mathrm{~d}, 9 \mathrm{H}, \mathrm{P}\left(\mathrm{CH}_{3}\right)_{3}\right), 1.43\left(\mathrm{~m}, 7 \mathrm{H}, \mathrm{CH}\left(\mathrm{CH}_{3}\right)_{2}\right), 1.36\left(\mathrm{~m}, 7 \mathrm{H}, \mathrm{CH}\left(\mathrm{CH}_{3}\right)_{2}\right)$, $1.26\left(\mathrm{~m}, 7 \mathrm{H}, \mathrm{CH}\left(\mathrm{CH}_{3}\right)_{2}\right),-12.01\left(\mathrm{dt}, J^{2} \mathrm{H}-\mathrm{P}=35.1 \mathrm{~Hz}, 58.1 \mathrm{~Hz}, 1 \mathrm{H}, \mathrm{Fe}-H\right) .{ }^{31} \mathrm{P}\left\{{ }^{1} \mathrm{H}\right\}$ NMR $(161 \mathrm{MHz}, \mathrm{THF}-$ 
$\left.d_{8}, \delta\right): 91.5\left(\mathrm{~d}, J_{\mathrm{P}-\mathrm{P}}^{2}=20.6 \mathrm{~Hz}, 2 \mathrm{P},{ }^{\mathrm{iPr}} P \mathrm{~N}^{\mathrm{H}} P\right),-1.2\left(\mathrm{t}, J_{\mathrm{P}-\mathrm{P}}^{2}=20.6 \mathrm{~Hz}, 1 \mathrm{P}, P \mathrm{Me}_{3}\right),-144.0\left(\mathrm{~s}, P \mathrm{~F}_{6}\right) .{ }^{19} \mathrm{~F} \mathrm{NMR}$ (471 MHz, THF- $d_{8}, \delta$ ): -68.8 (br, $\left.\mathrm{P} F_{6}\right) .{ }^{13} \mathrm{C}\left\{{ }^{1} \mathrm{H}\right\} \mathrm{NMR}$ (151 MHz, THF- $\left.d_{8}, \delta\right): 55.3$ (s), $33.3(\mathrm{t}, J=8.1 \mathrm{~Hz}$ ), $31.5(\mathrm{t} J=9.0 \mathrm{~Hz}), 23.4(\mathrm{~s}), 21.8(\mathrm{~s}), 21.1(\mathrm{~s}), 20.3(\mathrm{~s}), 19.3(\mathrm{~s}), 18.3(\mathrm{t}, J=3.3 \mathrm{~Hz}), 15.9,14.6,1.6$, carbonyl carbon not observed. IR (solid-state, $\left.\mathrm{cm}^{-1}\right): 3290\left(\mathrm{v}_{\mathrm{NH}}\right), 1904\left(\mathrm{v}_{\mathrm{CO}}, \mathrm{v}_{\mathrm{FeH}}\right), 1887\left(\mathrm{v}_{\mathrm{CO}}, \mathrm{v}_{\mathrm{FeH}}\right)$.
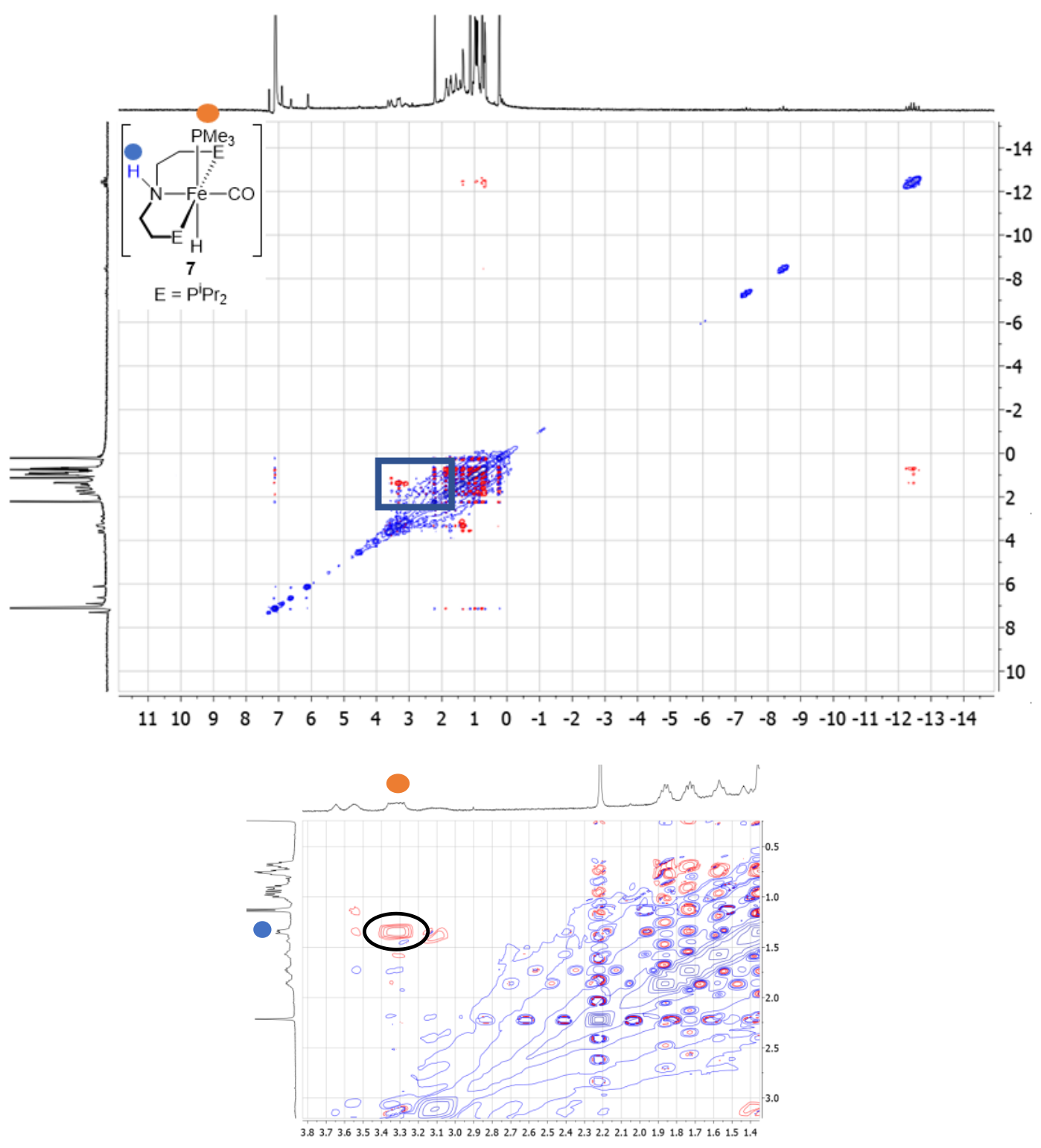

Figure S1. ${ }^{1} \mathrm{H}$ NOESY NMR spectrum of 7 (top), and inset (bottom), to determine the isomer present in solution. 
III. Protonation of 1 with Acids Containing a BAr ${ }_{4}{ }_{4}$ Counterion and Reactions of the Resulting Solution

Protonation of 1 with Brookhart's Acid or 2,6-Lutidinium BAr $^{\mathrm{F}_{4}}$ : A scintillation vial was charged with 1 (31.5 mg, $0.0809 \mathrm{mmols})$ and diethyl ether $(5 \mathrm{~mL})$ and cooled in the cold well of a glovebox to $-78{ }^{\circ} \mathrm{C}$. In a separate vial, a solution of Brookhart's acid $\left(\operatorname{HBAr}_{4}{ }_{4}, 81.6 \mathrm{mg}, 0.0806\right.$ mmols $)$ or 2,6-lutidinium $\mathrm{BAr}_{4}$ $(157 \mathrm{mg}, 0.162 \mathrm{mmols})$ in diethyl ether $(10 \mathrm{~mL})$ was prepared and cooled to $-78{ }^{\circ} \mathrm{C}$. The solution of the acid was added dropwise to the solution of $\mathbf{1}$, swirling the solution every 2-3 drops, while keeping the solutions cold inside the cold well. After the addition was complete, the solution was allowed to stand at $78{ }^{\circ} \mathrm{C}$ for 5 minutes. The solution was either used as generated or for some experiments the volatiles were removed in vacuo to yield a crude yellow solid. Purification could also be performed by reducing the reaction volume by $50 \%$ in vacuo, then adding $15 \mathrm{~mL}$ pentane (cooled to $-78{ }^{\circ} \mathrm{C}$ ) and allowing a yellow crystalline solid to precipitate over approximately 3 hours in the glovebox cold well. Single crystals were grown through slow diffusion of pentane into a concentrated $\mathrm{Et}_{2} \mathrm{O}$ solution at $-30{ }^{\circ} \mathrm{C}$. Selected NMR data for the mixture, which predominantly consists of $\left({ }^{\mathrm{iPr}} \mathrm{PN}{ }^{\mathrm{H}} \mathrm{P}\right) \mathrm{Fe}(\mathrm{H})(\mathrm{CO})\left(\mathrm{N}_{2}\right)\left(\mathbf{5}-\mathrm{N}_{2}\right):{ }^{1} \mathrm{H}$ NMR at $25{ }^{\circ} \mathrm{C}(500$ MHz, diethyl ether, $\delta): 7.64\left(\mathrm{~s}, \mathrm{~B} A r^{\mathrm{F}} 4\right), 7.43\left(\mathrm{~s}, \mathrm{~B} A r^{\mathrm{F}} 4\right),-15.64(\mathrm{br}, \mathrm{Fe} H) .{ }^{1} \mathrm{H}$ NMR at $-60{ }^{\circ} \mathrm{C}(500 \mathrm{MHz}$, diethyl ether, $\delta): 7.80\left(\mathrm{~s}, \mathrm{~B} A r_{4}^{\mathrm{F}}\right), 7.61\left(\mathrm{~s}, \mathrm{~B} A r_{4}^{\mathrm{F}}\right),-15.05\left(\mathrm{t}, J_{\mathrm{HP}}=50.9 \mathrm{~Hz}, \mathrm{Fe} H_{\mathrm{A}}\right),-15.29\left(\mathrm{t}, J_{\mathrm{HP}}=49.7 \mathrm{~Hz}\right.$, $\left.\mathrm{Fe} H_{\mathrm{B}}\right)$, Ratio $\mathrm{H}_{\mathrm{A}}: \mathrm{H}_{\mathrm{B}}: 3: 1 .{ }^{31} \mathrm{P} \mathrm{NMR}$ at $25{ }^{\circ} \mathrm{C}\left(202 \mathrm{MHz}\right.$, diethyl ether, $\delta$, referenced to a $\left(\mathrm{PPh}_{3}\right)_{3} \mathrm{PO}$ internal standard): 90.1 (br), 92.4 (br). ${ }^{31} \mathrm{P}\left\{{ }^{1} \mathrm{H}\right\}$ NMR at $-60{ }^{\circ} \mathrm{C}\left(202 \mathrm{MHz}\right.$, diethyl ether, $\delta$, referenced to a $\left(\mathrm{PPh}_{3}\right)_{3} \mathrm{PO}$ internal standard): $91.3(\mathrm{~s}), 92.9(\mathrm{~s}), 97.4(\mathrm{~s})$.

A ${ }^{31} \mathrm{P}\left\{{ }^{1} \mathrm{H}\right\} \mathrm{NMR}$ spectrum was recorded for a sample of $\mathbf{5 - \mathbf { N } _ { 2 }}$ in $\mathrm{Et}_{2} \mathrm{O}$. The sample was then subjected to three freeze-pump-thaw cycles and sealed under vacuum. $A{ }^{31} \mathrm{P}\left\{{ }^{1} \mathrm{H}\right\} \mathrm{NMR}$ spectrum was obtained under vacuum, and then another spectrum obtained after the sample had been exposed to a $\mathrm{N}_{2}$ atmosphere. The signals corresponding to $\mathbf{5 - \mathbf { N } _ { 2 }}$ drastically decreased in intensity upon removal of the $\mathrm{N}_{2}$ atmosphere and regained intensity upon subsequent $\mathrm{N}_{2}$ exposure, 
indicating $\mathrm{N}_{2}$ coordination. A corresponding color change from yellow to green and back was also observed. Data for this experiment is shown in Figures S2-S3, below.

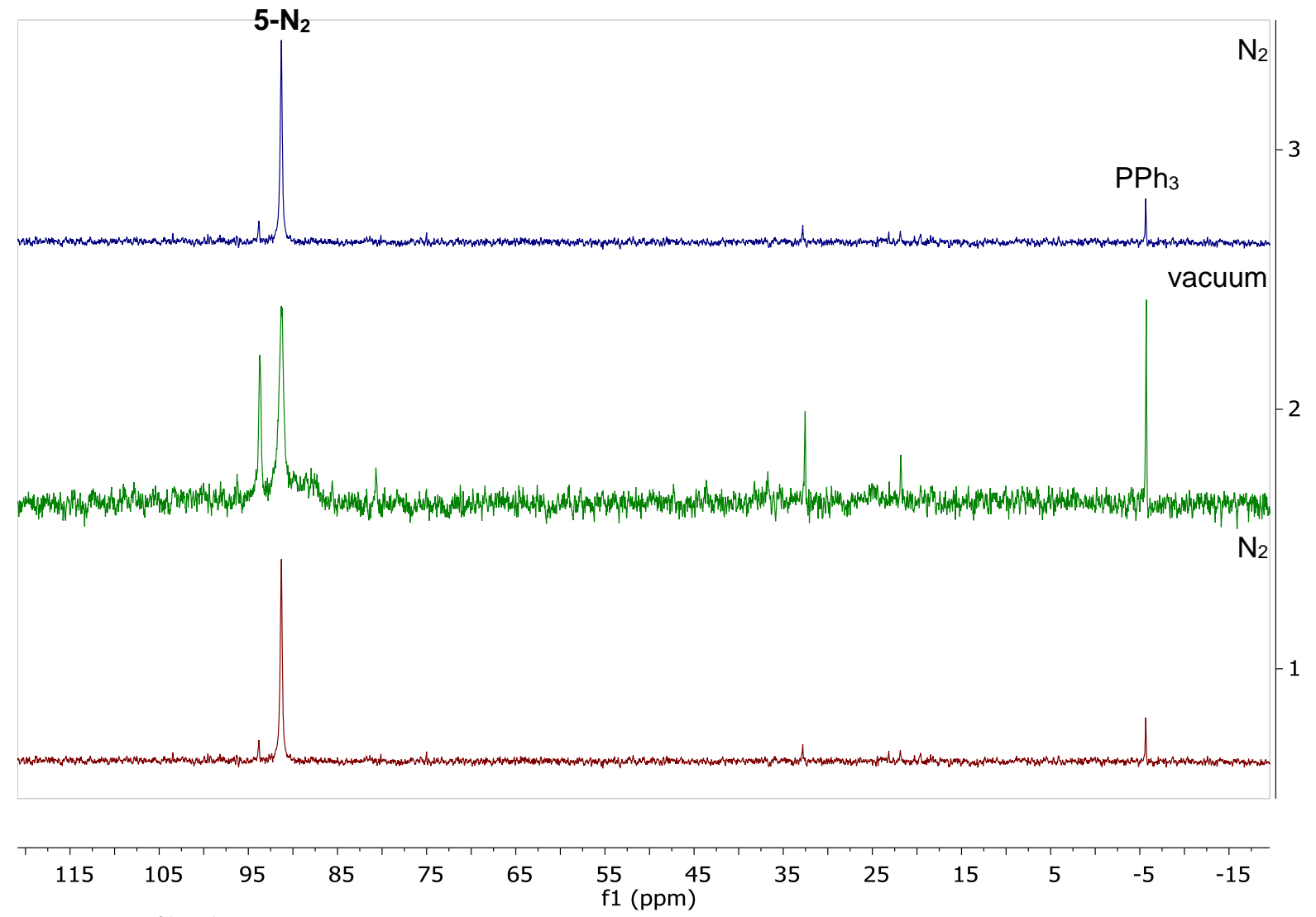

Figure $\mathrm{S} 2 .{ }^{31} \mathrm{P}\left\{{ }^{1} \mathrm{H}\right\}$ NMR spectra of $\mathbf{5}-\mathbf{N}_{2}$ under an $\mathrm{N}_{2}$ atmosphere, under vacuum, and then under $\mathrm{N}_{2}$ again, showing loss and then recovery of signal. Internal $\mathrm{PPh}_{3}$ capillary used.
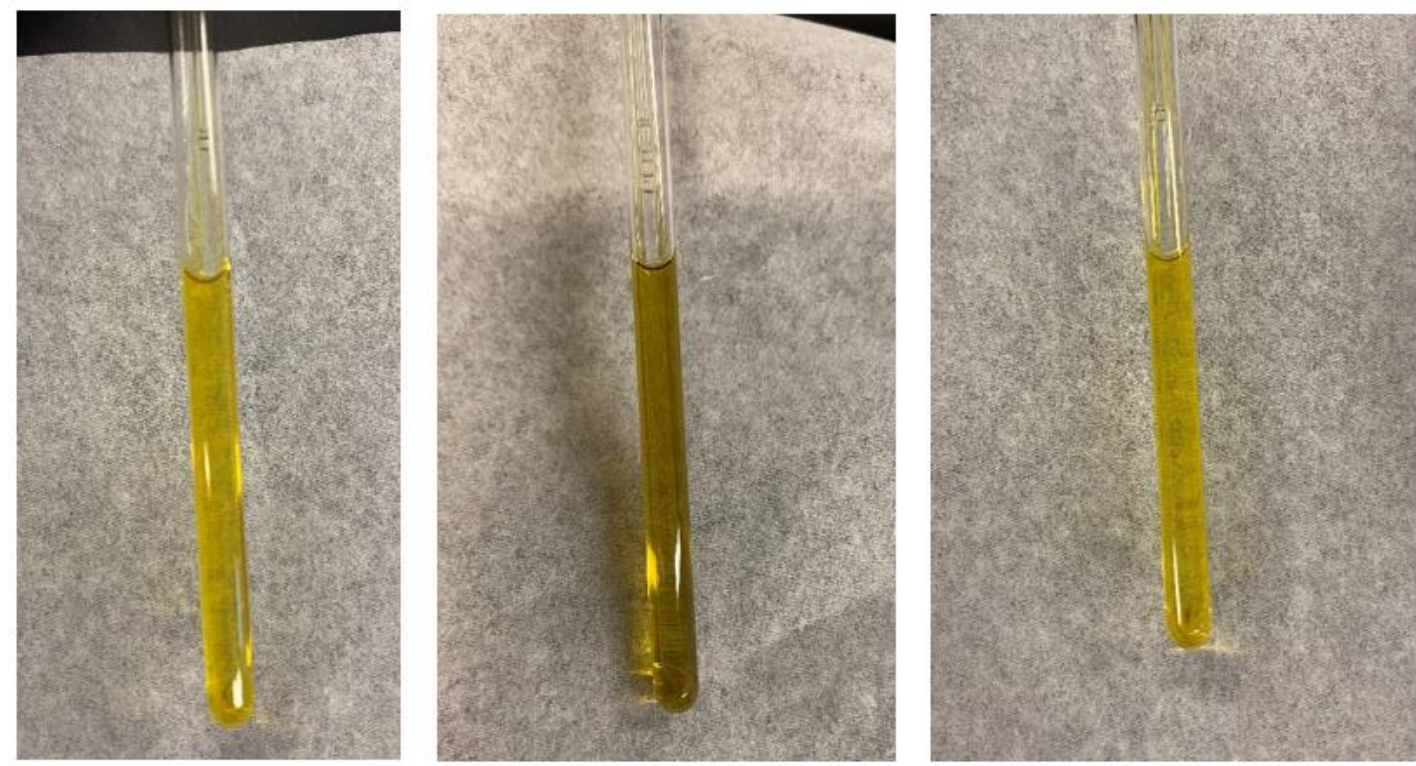

Figure $\mathrm{S} 3$. Photos of a sample of $\mathbf{5}-\mathbf{N}_{2}$ under $\mathrm{N}_{2}$ (left), vacuum (middle), and $\mathrm{N}_{2}$ again (right). 
To probe the observation of a water adduct in one of the solid-state samples of $\mathbf{5 - \mathbf { N } _ { 2 }}$, an NMR sample of 5- $\mathbf{N}_{2}$ in $\mathrm{Et}_{2} \mathrm{O}$ was reacted with $1 \mu \mathrm{L} \mathrm{H}_{2} \mathrm{O}$ ( 2-4 equiv.) at room temperature to form what are proposed as two isomers (4:1 ratio) of the water-bound species $\left({ }^{\mathrm{iPr}} \mathrm{PN}^{\mathrm{H}} \mathrm{P}\right) \mathrm{Fe}(\mathrm{H})(\mathrm{CO})\left(\mathrm{OH}_{2}\right)(\mathbf{5}-$ $\left.\mathbf{H}_{2} \mathbf{O}\right) .{ }^{1} \mathrm{H}$ and ${ }^{31} \mathrm{P}\left\{{ }^{1} \mathrm{H}\right\}$ NMR spectra are included in Figures S4 and S5 below. Two isomers are proposed based on the similarity of chemical shifts in NMR spectra and by comparison to similar complexes. This species is not observed by NMR in the protonation of $\mathbf{1}$ with $\mathrm{HLutBAr}_{4} \mathrm{~F}_{4}$ in $\mathrm{Et}_{2} \mathrm{O}$, as shown above. This supports our hypothesis that the co-crystallization of $\mathbf{5}-\mathbf{N}_{2}$ with $\mathbf{5}-\mathbf{H}_{2} \mathrm{O}$ is the result of adventitious water, and $\mathbf{5}-\mathbf{H}_{2} \mathrm{O}$ is not a common byproduct.
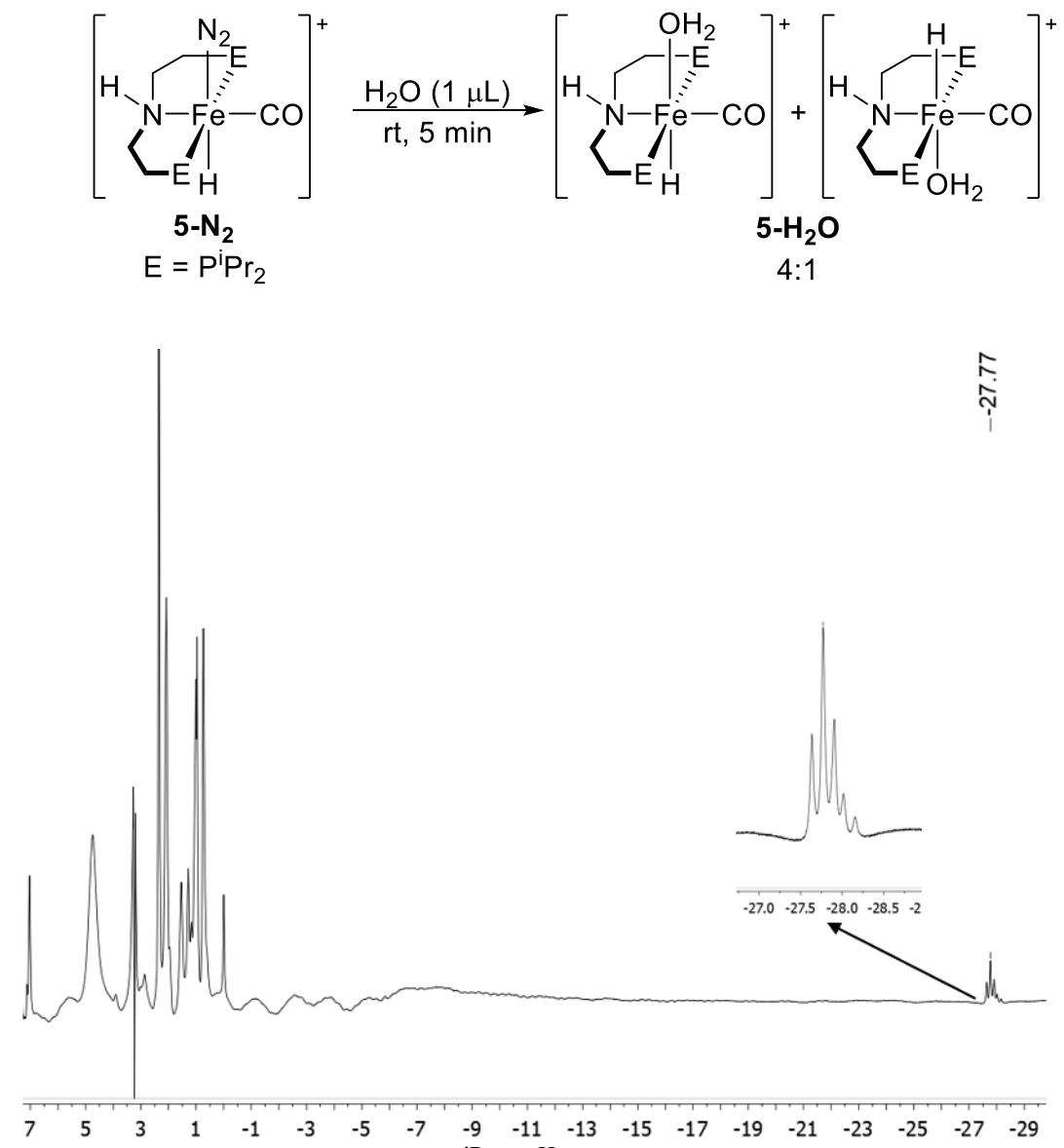

Figure S4. ${ }^{1} \mathrm{H}$ NMR of two isomers of $\left({ }^{\mathrm{iP}}{ }^{\mathrm{P} N}{ }^{\mathrm{H}} \mathrm{P}\right) \mathrm{Fe}(\mathrm{H})(\mathrm{CO})\left(\mathrm{OH}_{2}\right)\left(\mathbf{5}-\mathrm{H}_{2} \mathrm{O}\right)$ in $\mathrm{Et}_{2} \mathrm{O}$ at room temperature. Inset of hydride region included for clarity. Solvent suppression leads to fluctuation in baseline. 


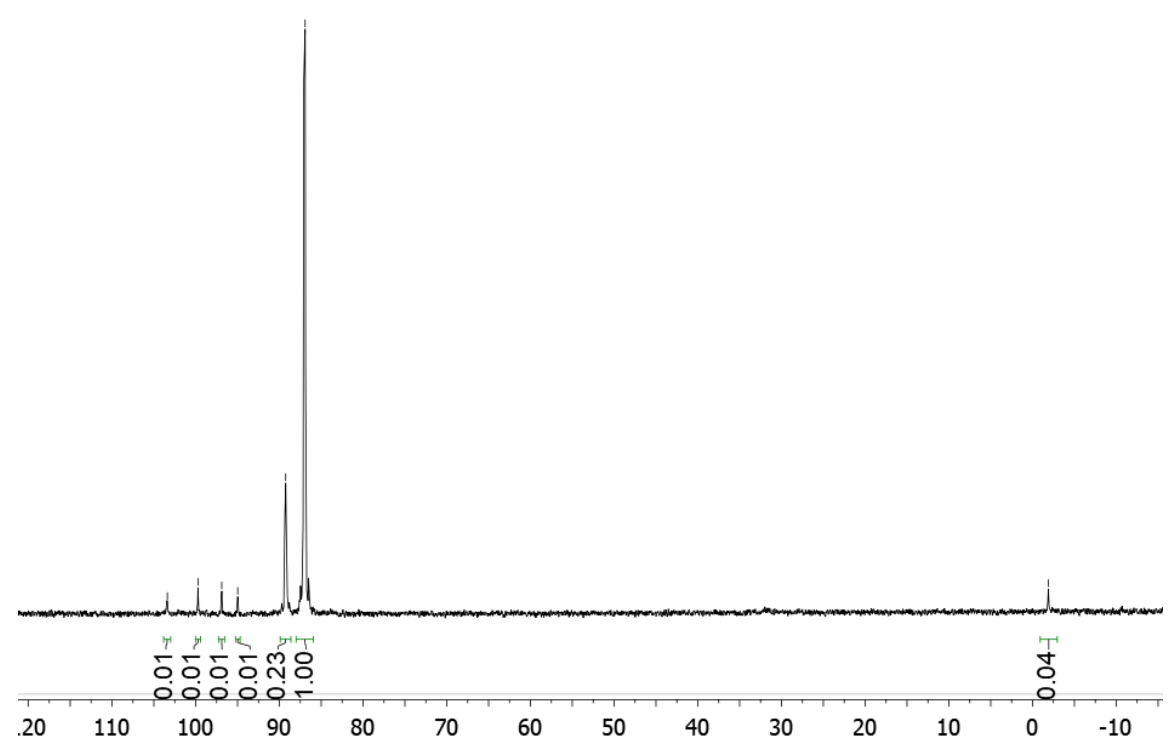

Figure S5. ${ }^{31} \mathrm{P}\left\{{ }^{1} \mathrm{H}\right\}$ NMR of $\left({ }^{\mathrm{iPr}} \mathrm{PN}{ }^{\mathrm{H}} \mathrm{P}\right) \mathrm{Fe}(\mathrm{H})(\mathrm{CO})\left(\mathrm{OH}_{2}\right)\left(\mathbf{5}-\mathbf{H}_{2} \mathrm{O}\right)$ in $\mathrm{Et}_{2} \mathrm{O}$ at room temperature. Two isomers proposed at 86.9 and $89.3 \mathrm{ppm}$. Small amount of ${ }^{\mathrm{iPr}} \mathrm{PN}^{\mathrm{H}} \mathrm{P}$ present at $-1.89 \mathrm{ppm}$.

To further support the assignment of $\mathbf{5 - H _ { 2 }} \mathbf{O}$ as a water adduct, a reaction was performed between 6 and $\mathrm{H}_{2} \mathrm{O}$. As shown in the spectra below (Figures S6-S8), there is a close resemblance between the spectra for $\mathbf{5}-\mathrm{H}_{2} \mathrm{O}$ and those generated through the reaction of $\mathbf{6}$ with $\mathrm{H}_{2} \mathrm{O}$. This supports our assignment of $\mathbf{5}-\mathrm{H}_{2} \mathrm{O}$.

Procedure for the reaction of 6 with $\mathrm{H}_{2} \mathrm{O}$ : A sample of 6 (5.0 mg, 0.00936 mmols) was dissolved in $\mathrm{C}_{6} \mathrm{D}_{6}(0.50 \mathrm{~mL}) . \mathrm{H}_{2} \mathrm{O}(1.0 \mu \mathrm{L}, 0.055 \mathrm{mmols})$ was added, and ${ }^{1} \mathrm{H},{ }^{31} \mathrm{P}\left\{{ }^{1} \mathrm{H}\right\}$ and ${ }^{19} \mathrm{~F}$ NMR spectra were taken (Figures S6-S8). The large changes in chemical shifts, along with the sharpness of the peaks, indicate that a species distinct from $\mathbf{6}$ is formed. Additionally, these spectra closely match that of 5-H2O (see Figures S4-S5). 


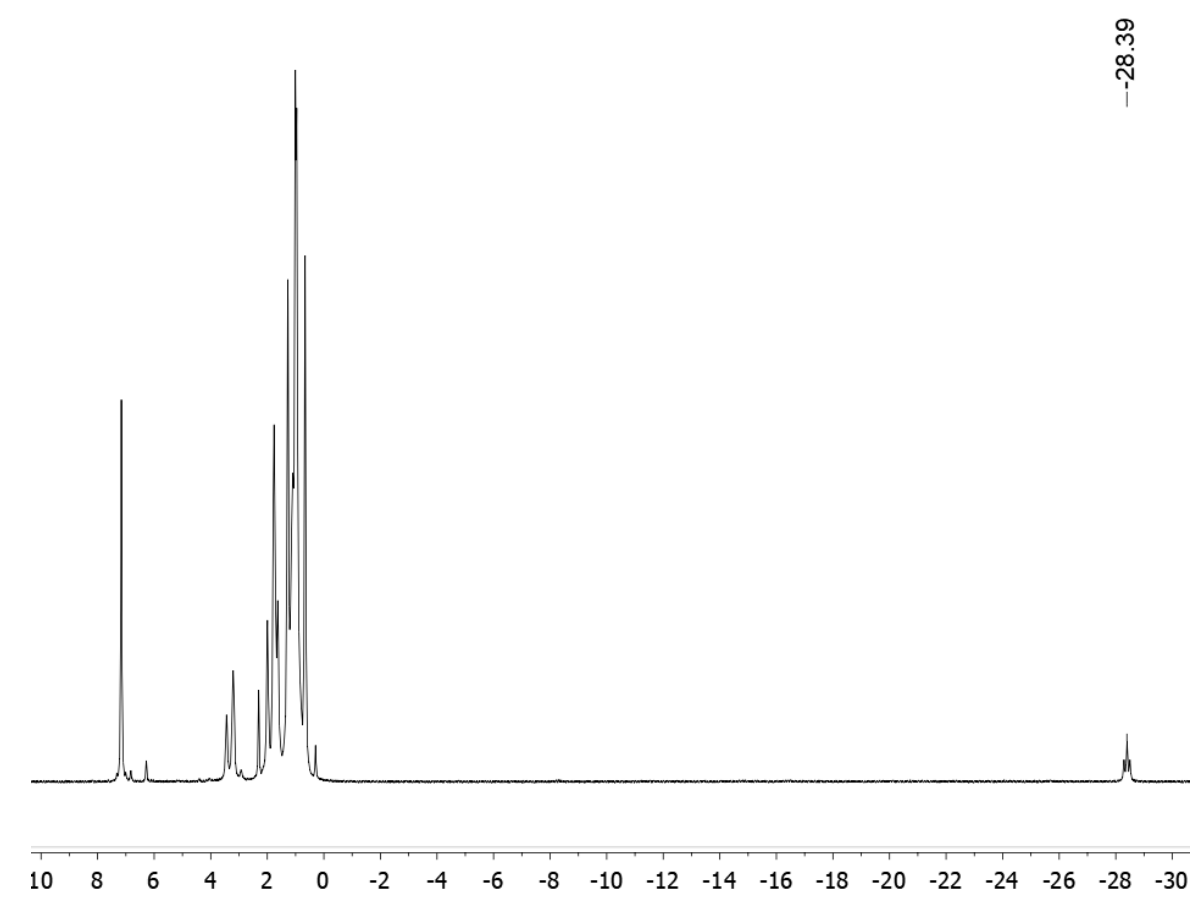

Figure S6. ${ }^{1} \mathrm{H}$ NMR spectrum of the reaction of 6 with $\mathrm{H}_{2} \mathrm{O}$.

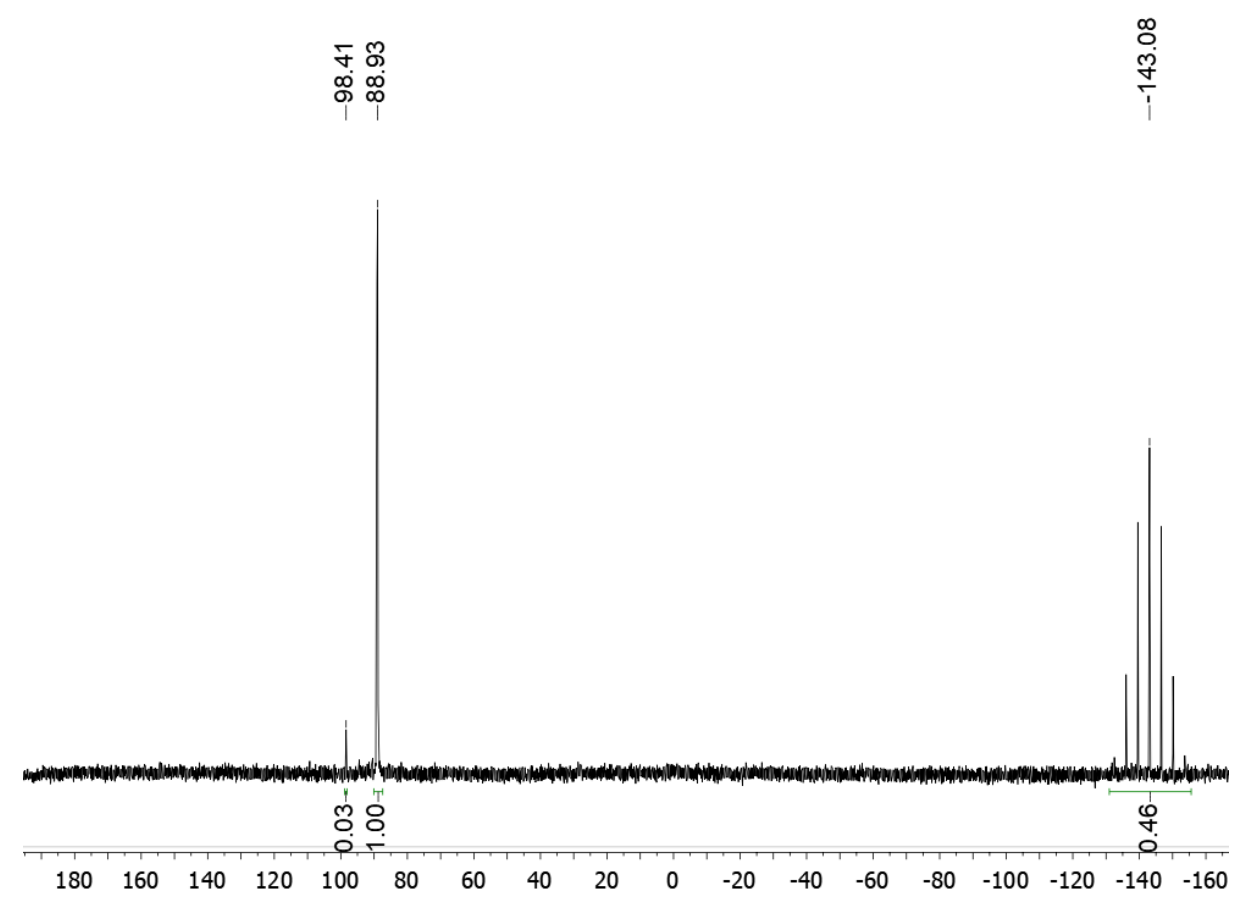

Figure S7. ${ }^{31} \mathrm{P}\left\{{ }^{1} \mathrm{H}\right\}$ NMR spectrum of the reaction of 6 with $\mathrm{H}_{2} \mathrm{O}$. Small amount of 4 present at 98.41 ppm. 


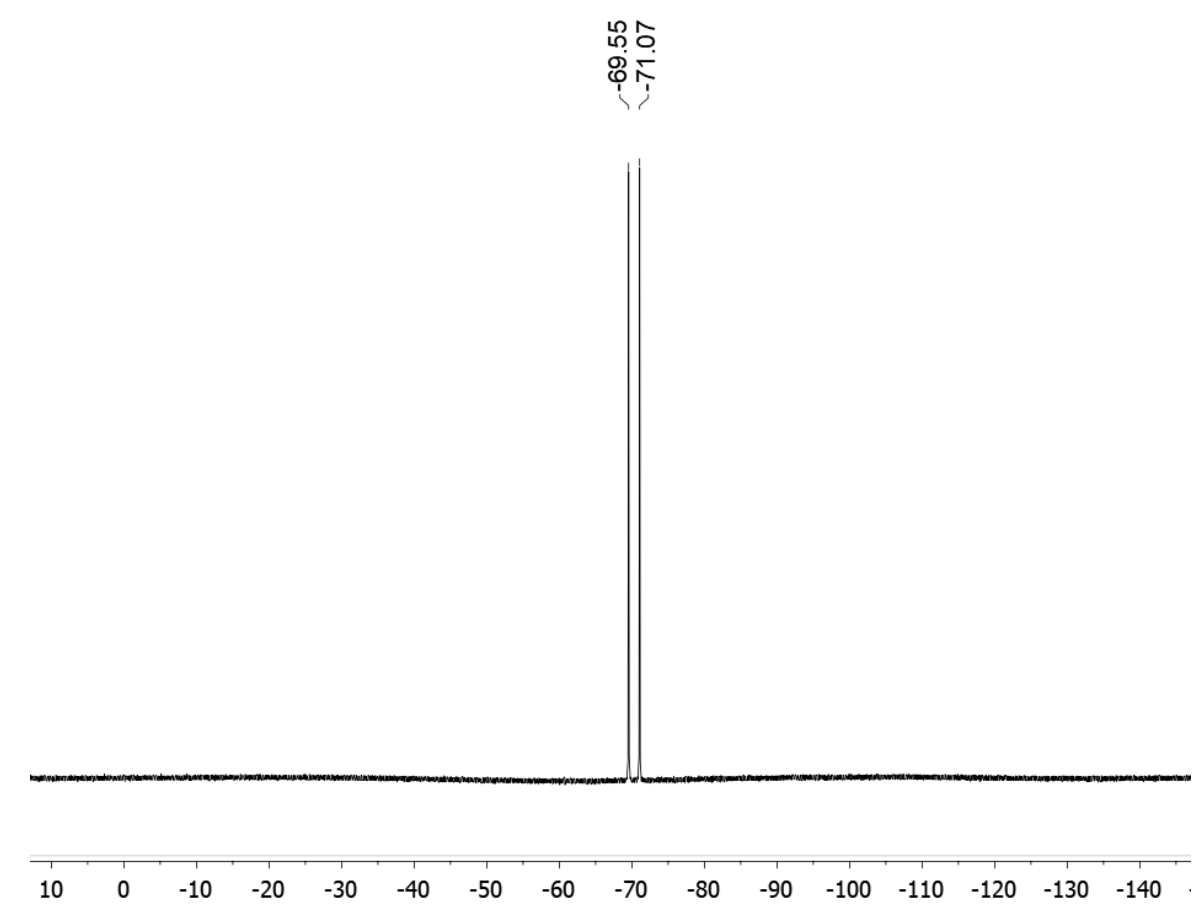

Figure S8. ${ }^{19} \mathrm{~F}$ NMR spectrum of the reaction of 6 with $\mathrm{H}_{2} \mathrm{O}$.

Reaction of Protonated 1 with ${ }^{{ }^{n}} \mathbf{B u}_{4} \mathbf{N P F}_{6}$ to Generate 6: A solution of protonated $\mathbf{1}$ (2.8 $\mathrm{mg}, 0.0070$ mmols) was formed and the solvent removed in vacuo. The solid was then dissolved in $500 \mu \mathrm{L}$ of THF and 2 equiv. of ${ }^{\mathrm{n}} \mathrm{Bu}_{4} \mathrm{NPF}_{6}$ were added (5.3 mg, $\left.0.014 \mathrm{mmols}\right)$. Then ${ }^{31} \mathrm{P}\left\{{ }^{1} \mathrm{H}\right\}$ and ${ }^{1} \mathrm{H}$ NMR spectra with solvent suppression were recorded. The spectra observed matched those reported above for $\mathbf{6}$.

Reaction of Protonated 1 with CO to Generate 4: A solution of protonated 1 ( $c a .5 \mathrm{mg}$ ) was formed and the solvent removed in vacuo. The solid was then dissolved in $500 \mu \mathrm{L}$ of THF, transferred to a J Young NMR tube, and subjected to three freeze-pump-thaw cycles before being filled with 1 atm of CO. The orange solution was inverted and the solution immediately became colorless. Then ${ }^{31} \mathrm{P}\left\{{ }^{1} \mathrm{H}\right\}$ and ${ }^{1} \mathrm{H}$ NMR spectra with solvent suppression were recorded. The spectra observed matched those reported in the literature for $4 .^{5}$ 
Reaction of Protonated 1 with $\mathrm{PMe}_{3}$ to Generate 7: A solution of protonated 1 was formed and the solvent removed in vacuo. Approximately $5 \mathrm{mg}$ of the resultant solid was then dissolved in $500 \mu \mathrm{L}$ of THF and a drop of $\mathrm{PMe}_{3}(c a .50 \mu \mathrm{L})$ added. Then ${ }^{31} \mathrm{P}\left\{{ }^{1} \mathrm{H}\right\}$ and ${ }^{1} \mathrm{H}$ NMR spectra with solvent suppression were recorded. The spectra observed matched those reported above for 7 .

Reaction of Protonated 1 with THF: A solution of protonated 1 ( $c a .5 \mathrm{mg}$ ) was formed and the solvent removed in vacuo. The solid was then dissolved in $500 \mu \mathrm{L}$ of THF-d $\mathrm{d}_{8}$ and transferred to a J Young NMR tube. Selected ${ }^{1} \mathrm{H}$ NMR at $25{ }^{\circ} \mathrm{C}(500 \mathrm{MHz}$, tetrahydrofuran, $\delta):-29.1$ (br), $7.75\left(\mathrm{~s}, 4 \mathrm{H}, \mathrm{BAr}{ }_{4}\right), 7.76(\mathrm{~s}, 8 \mathrm{H}$, $\left.\mathrm{B} A r^{\mathrm{F}} 4\right) .{ }^{31} \mathrm{P}\left\{{ }^{1} \mathrm{H}\right\} \mathrm{NMR}$ at $25{ }^{\circ} \mathrm{C}(202 \mathrm{MHz}$, tetrahydrofuran, $\delta): 85.7$ (br). ${ }^{31} \mathrm{P}\left\{{ }^{1} \mathrm{H}\right\} \mathrm{NMR}$ at $0{ }^{\circ} \mathrm{C}(202 \mathrm{MHz}$, tetrahydrofuran, $\delta): 85.9(\mathrm{~s}), 92.0\left(\mathbf{5}-\mathbf{N}_{\mathbf{2}}, \mathrm{s}\right), 99.0(\mathbf{4}, \mathrm{s})$.

Monitoring Decomposition of 6 or a Solution of Protonated 1: A sample of 6 (5.0 mg, $0.00936 \mathrm{mmols}$ ) or in situ protonated 1 (5.2 mg, $0.0134 \mathrm{mmols}$, of 1, diethyl ether removed in vacuo) was dissolved in THF $(500 \mu \mathrm{L})$ and transferred to a $\mathrm{J}$ Young NMR tube containing a capillary filled with $\mathrm{PPh}_{3}$ in $\mathrm{C}_{6} \mathrm{D}_{6}$. The integration of the ${ }^{31} \mathrm{P}$ NMR peak of the starting material relative to the standard was monitored until it could not be observed (ca. 8-12 hours). 


\section{Synthesis of 8 in situ, $T_{1}$ Determination, and HD Adduct Spectrum}

A sample of 6 or the mixture from protonation of 1 with $\mathrm{HBAr}^{\mathrm{F}}{ }_{4}$ was dissolved in $c a .450 \mu \mathrm{L}$ of THF- $d_{8}$ and transferred to a J. Young NMR tube. The J. Young was sealed and subjected to 3 freeze-pump-thaw cycles. Then, the tube was filled with 1 atm $\mathrm{H}_{2}$ and NMR spectra were recorded. Single crystals suitable for X-ray diffraction were obtained by repeating this identical procedure but using $\mathbf{6}$ and benzene as the solvent and allowing the mixture to stand after $\mathrm{H}_{2}$ addition for one week. Larger crystals could be obtained by repeating this procedure in the presence of 2 or 3 seed crystals. Selected ${ }^{1} \mathrm{H}$ NMR data $(500 \mathrm{MHz}$, THF$\left.d_{8}, \delta\right): 7.77\left(\mathrm{~s}, \mathrm{~B} A r^{\mathrm{F}}\right), 7.55\left(\mathrm{~s}, \mathrm{~B} A r^{\mathrm{F}}\right),-5.55\left(\mathrm{br}, \mathrm{Fe} H_{2}\right),-11.82\left(\mathrm{t}, J_{\mathrm{HP}}=49.3 \mathrm{~Hz}, \mathrm{Fe} H\right),-11.97\left(\mathrm{t}, J_{\mathrm{HP}}=51.4\right.$ $\mathrm{Hz}, \mathrm{Fe} H$ ). The major isomer in solution was determined by $2 \mathrm{D}{ }^{1} \mathrm{H}$ NOESY NMR (500 ms mixing time) to have the $\mathrm{H}_{2}$ ligand syn to the N-H moiety, as shown in Figure S9 below. Selected ${ }^{31} \mathrm{P}\left\{{ }^{1} \mathrm{H}\right\}$ NMR data (202 MHz, THF- $\left.d_{8}, \delta\right): 105.3(\mathrm{~s}), 104.0(\mathrm{~s})$. The $\mathrm{H}_{2}$-bound complex 8 is in equilibrium with the THF-bound complex 5-THF at room temperature in THF. This equilibrium precludes the definitive assignment of ${ }^{1} \mathrm{H}$ NMR peaks derived from the ${ }^{\mathrm{iPr}} \mathrm{PN}^{\mathrm{H}} \mathrm{P}$ ligand. Selected ${ }^{19} \mathrm{~F}$ NMR data (376 MHz, THF- $\left.d_{8}, \delta\right):-65.2$ (br).

The $T_{1}$ of the $\mathrm{H}_{2}$ ligand was measured using a selective spin-inversion recovery experiment of the peak at $-5.55 \mathrm{ppm}$. This measurement was repeated at multiple temperatures to estimate the temperature at which the minimum value of $T_{1}$ would be obtained. A plot of $1 / \mathrm{T}$ vs. $\ln \left(T_{1}\right)$ can be found in Figure $\mathrm{S} 10$. The value of $T_{1}(\mathrm{~min})$ obtained by this method was then used in Morris' corrected equations ${ }^{6}$ to determine the range of possible $\mathrm{H}-\mathrm{H}$ distances, depending on whether the $\mathrm{H}_{2}$ ligand exists in the slow- or fast-rotating regime (Equations S1-S3), where $v$ is the spectrometer frequency. 


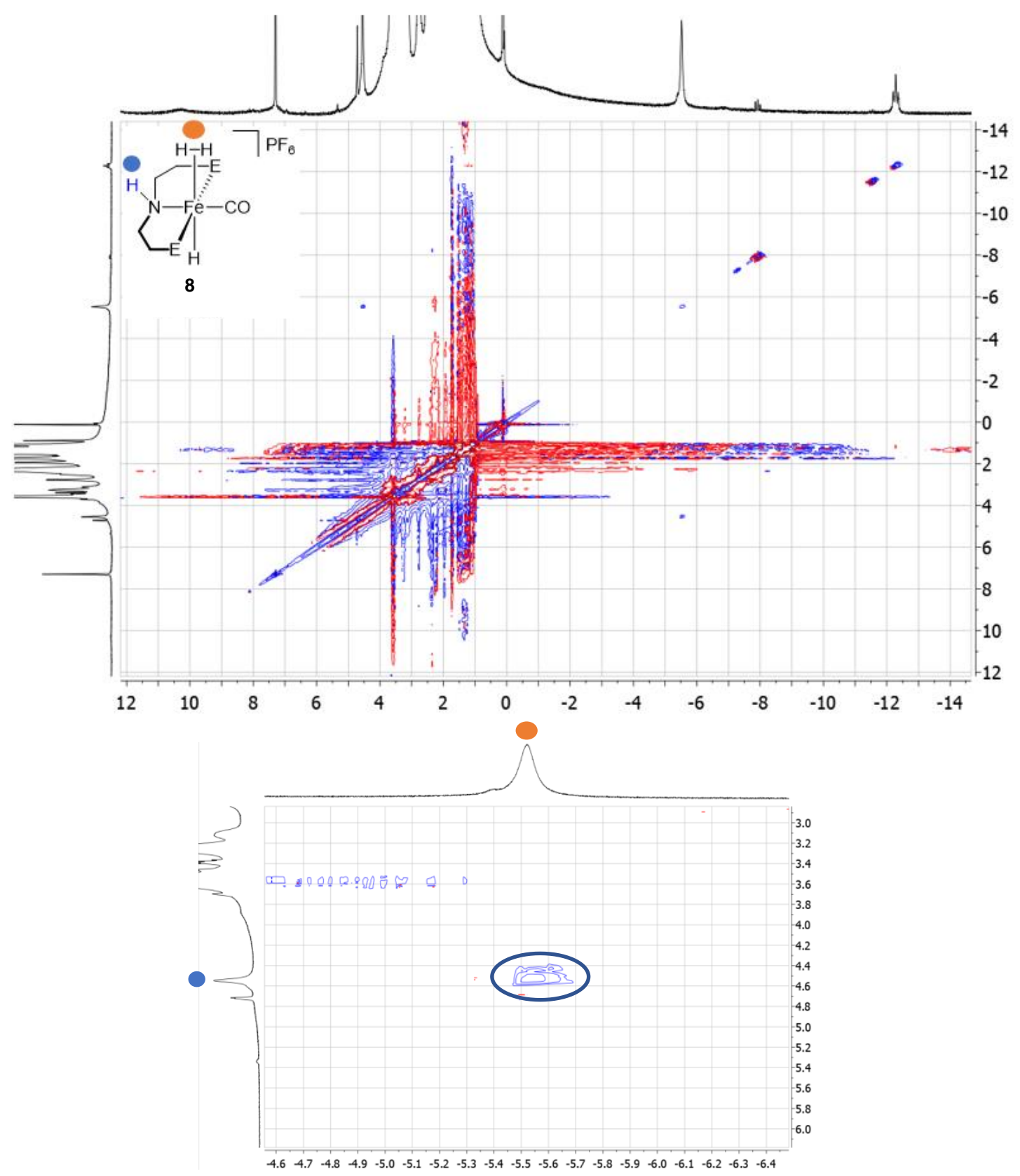

Figure S9. ${ }^{1} \mathrm{H}$ NOESY NMR spectrum of $\mathbf{8}$ (top), and inset (bottom), to determine the major isomer present in solution. 


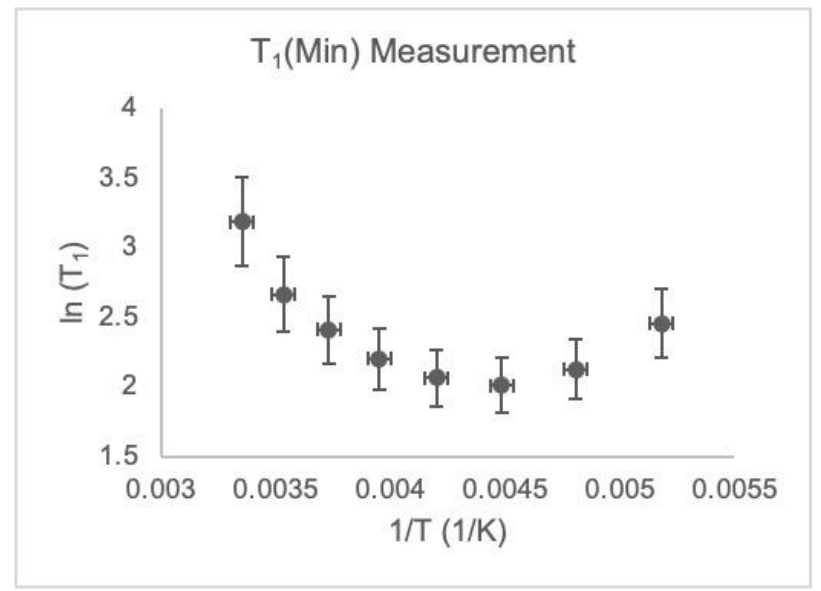

Figure S10. Graph of $T_{1}(\mathrm{~min})$ at various temperatures used to determine the minimum value for use in Eq.

$$
\begin{gathered}
2 \text { and Eq. S3. } \\
d_{H H}=147-1.75 J_{H D}(\text { Eq. S1) } \\
d_{H H}^{\text {slow }}=58.15 \sqrt[6]{\frac{T_{1}^{\text {min }}}{v}} \text { (Eq. S2) } \\
d_{H H}^{\text {fast }}=461 \sqrt[6]{\frac{T_{1}^{\text {min }}}{v}}(\text { Eq. S3) }
\end{gathered}
$$

The synthesis of $\mathbf{8}$ was performed as described above with one atmosphere of HD gas in an attempt to measure the HD coupling constant and extrapolate the H-H bond length. However, the overlapping peaks of the two isomers made this impossible to do accurately, even with line fitting. The spectra are shown in Figures S11-S12 below. 


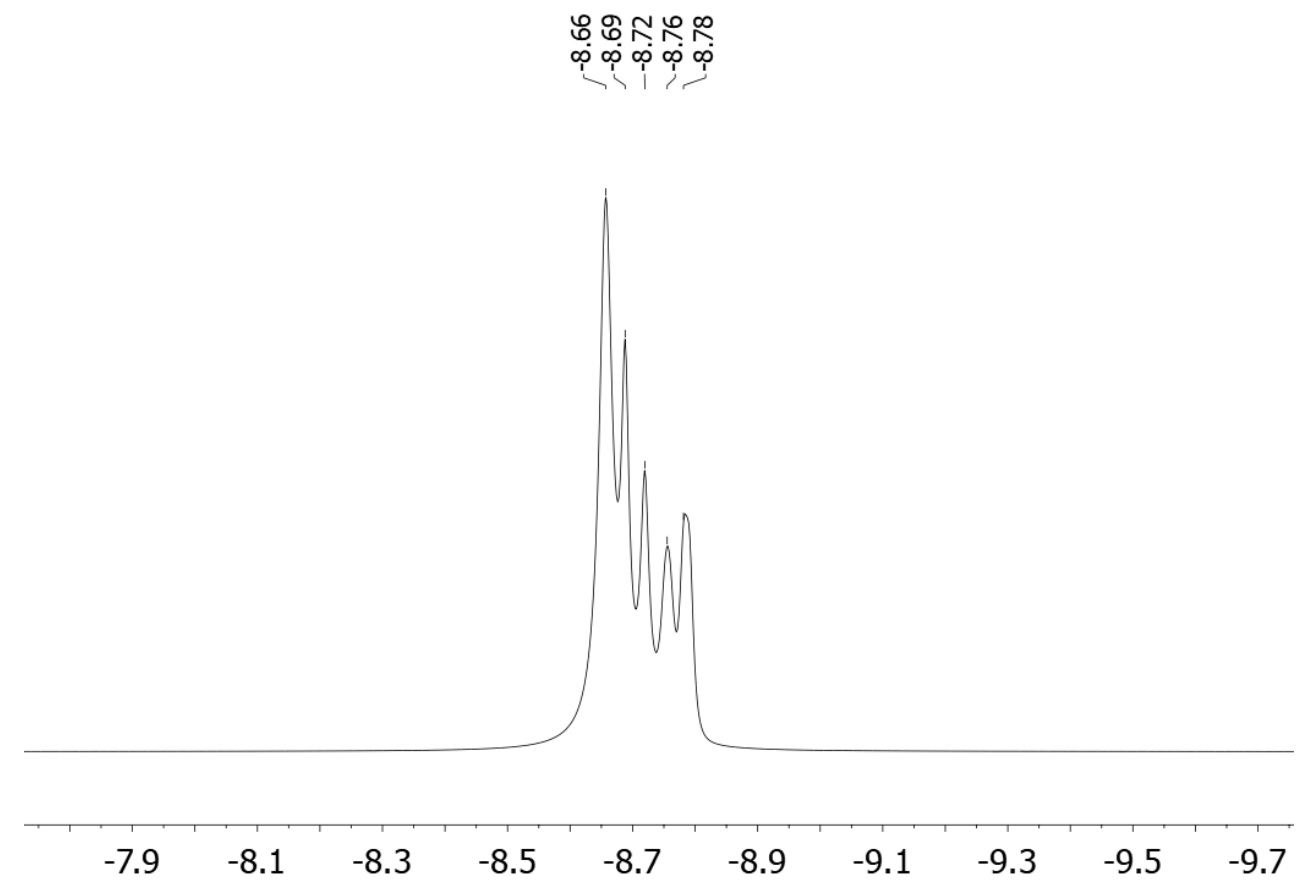

Figure S11. ${ }^{1} \mathrm{H}$ NMR of 8 synthesized using HD gas. The HD peaks for the two isomers are overlapping.

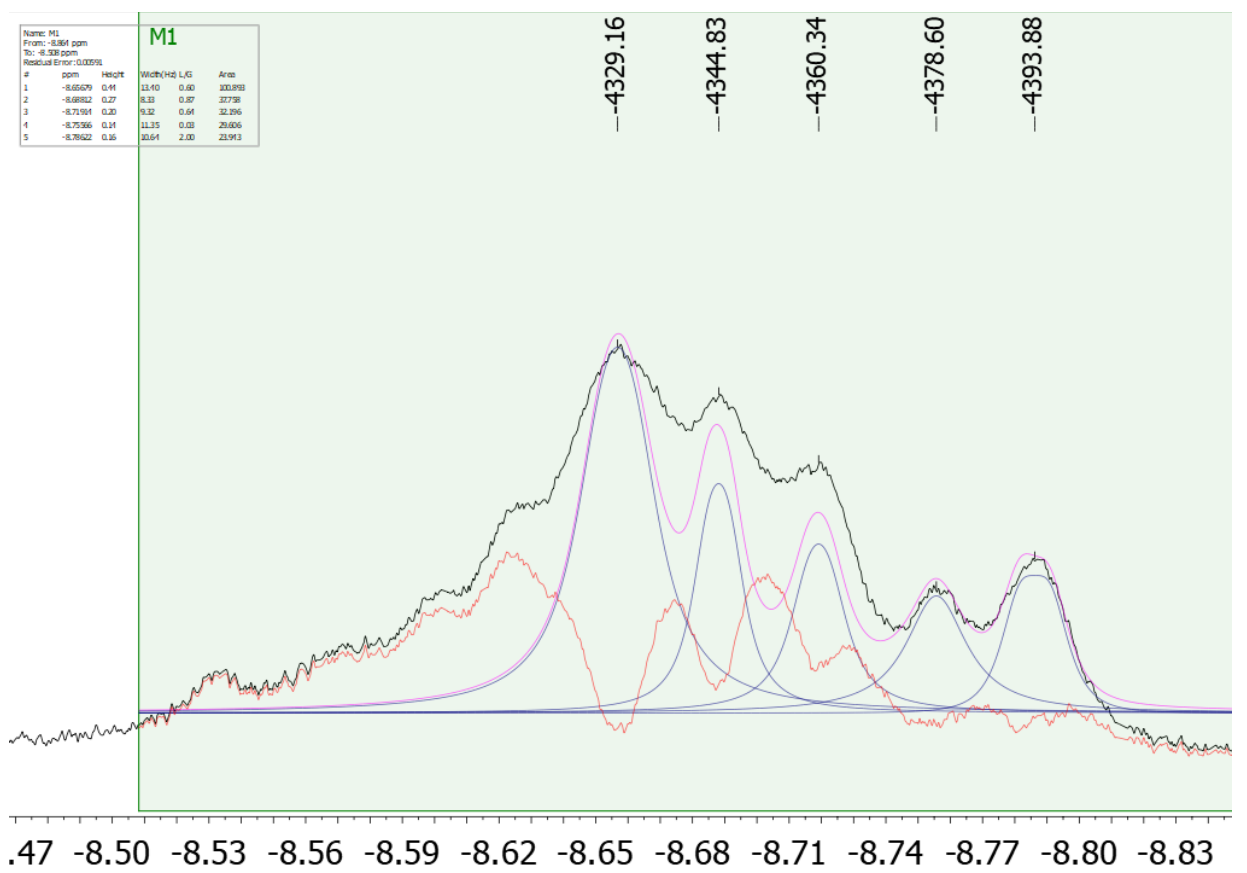

Figure S12. ${ }^{1} \mathrm{H}$ NMR of 8 synthesized using HD gas. Line fitting was used in an attempt to find the HD coupling constant, but the peak overlap precluded this from being done accurately. 


\section{Synthesis of $\left({ }^{i P r} P N^{H} P\right) F e$ Dimers 11 and 12}

Synthesis of $\left[\left\{\left({ }^{\mathrm{iPr}} \mathbf{P N}{ }^{\mathrm{H}} \mathbf{P}\right) \mathbf{F e}(\mathbf{H})(\mathbf{C O})\right\}_{2}\{\mu-\mathbf{C N}\}\right]\left[\mathbf{P F}_{6}\right](11)$ : In a vial, 1 (51.5 mg, $\left.0.132 \mathrm{mmols}\right)$ was dissolved in THF ( $5 \mathrm{~mL})$. To this, a solution of 2,6-lutidinium hexafluorophosphate ( $34.2 \mathrm{mg}, 0.135 \mathrm{mmols})$ in THF ( $5 \mathrm{~mL}$ ) was added, causing an immediate color change from dark red to orange, indicating in situ formation of $\mathbf{6}$. (It is also possible to use an isolated sample of $\mathbf{6}$, however this is challenging because of the instability of 6). A solution of tetrabutylammonium cyanide (17.6 mg, $0.0656 \mathrm{mmols})$ in THF (3 mL) was added, causing the color to change upon swirling to bright yellow over the course of less than 5 minutes. The volatiles were removed in vacuo and the product was extracted in benzene $(3 \times 2 \mathrm{~mL})$ and lyophilized. This extraction was repeated two more times, and the product was recrystallized by slow diffusion of pentane into toluene. Yield: $47.2 \mathrm{mg}(77 \%)$. Despite repeated attempts, analytical purity could not be established via elemental analysis. The ${ }^{1} \mathrm{H},{ }^{13} \mathrm{C}$, and ${ }^{31} \mathrm{P}$ NMR of $\mathbf{1 1}$ are included below to establish purity and identity. ${ }^{1} \mathrm{H}$ NMR (500 MHz, $\left.\mathrm{C}_{6} \mathrm{D}_{6}, \delta\right): 3.14\left(\mathrm{~m}, 2 \mathrm{H}, \mathrm{CH}_{2}\right), 3.06\left(\mathrm{~m}, 2 \mathrm{H}, \mathrm{CH}_{2}\right), 2.84$ (br, $\left.1 \mathrm{H}, \mathrm{NH}\right), 2.68$ (br, $1 \mathrm{H}, \mathrm{NH}), 1.96\left(\mathrm{~m}, 5 \mathrm{H}, \mathrm{CH}\left(\mathrm{CH}_{3}\right)_{2}\right.$ and $\left.\mathrm{CH}_{2}\right), 1.84\left(\mathrm{~m}, 3 \mathrm{H}, \mathrm{CH} \mathrm{H}_{2}\right), 1.62-1.71\left(\mathrm{~m}, 4 \mathrm{H}, \mathrm{CH}\left(\mathrm{CH}_{3}\right)_{2}\right)$, $1.45-1.56\left(\mathrm{~m}, 13 \mathrm{H}, \mathrm{CH}_{2}\right.$ and $\left.\mathrm{CH}\left(\mathrm{CH}_{3}\right)_{2}\right), 1.10-1.25\left(\mathrm{~m}, 23 \mathrm{H}, \mathrm{CH}\left(\mathrm{CH}_{3}\right)_{2}\right), 0.81-0.90\left(\mathrm{~m}, 13 \mathrm{H}, \mathrm{CH}\left(\mathrm{CH}_{3}\right)_{2}\right)$, $-13.76\left(\mathrm{t}, J_{\mathrm{H}-\mathrm{P}}^{2}=55.3 \mathrm{~Hz}, \mathrm{Fe} H\right),-20.83\left(\mathrm{t}, J_{\mathrm{H}-\mathrm{P}}^{2}=54.1 \mathrm{~Hz}, \mathrm{Fe} H\right) .{ }^{31} \mathrm{P}\left\{{ }^{1} \mathrm{H}\right\} \mathrm{NMR}\left(202 \mathrm{MHz}, \mathrm{C}_{6} \mathrm{D}_{6}, \delta\right): 97.8$ (s, $\left.{ }^{\mathrm{iPr}} P \mathrm{~N}^{\mathrm{H}} \mathrm{P}\right), 92.2\left(\mathrm{~s},{ }^{\mathrm{iPr}} P \mathrm{~N}^{\mathrm{H}} \mathrm{P}\right),-143.1$ (septet, $\left.J_{\mathrm{P}-\mathrm{F}}=712 \mathrm{~Hz}, P \mathrm{~F}_{6}\right) .{ }^{19} \mathrm{~F} \mathrm{NMR}\left(471 \mathrm{MHz}, \mathrm{C}_{6} \mathrm{D}_{6}, \delta\right):-71.45(\mathrm{~d}$, $\left.J_{\mathrm{P}-\mathrm{F}}=712 \mathrm{~Hz}, \mathrm{P} F_{6}\right) .{ }^{13} \mathrm{C}\left\{{ }^{1} \mathrm{H}\right\} \mathrm{NMR}\left(151 \mathrm{MHz}, \mathrm{C}_{6} \mathrm{D}_{6}, \delta\right): 58.6(\mathrm{~s}), 54.4(\mathrm{t}, J=4.6 \mathrm{~Hz}), 54.1(\mathrm{t}, J=4.6 \mathrm{~Hz})$, $31.2(\mathrm{t}, J=4.2 \mathrm{~Hz}), 28.8(\mathrm{q}, J=9.0 \mathrm{~Hz}), 28.6(\mathrm{t}, J=7.1 \mathrm{~Hz}), 25.2(\mathrm{t}, J=14.2 \mathrm{~Hz}), 24.7(\mathrm{t}, J=16.2 \mathrm{~Hz})$, 23.9 (s), 21.1 (d, J = 6.4 Hz), 20.7 (s), 20.5 (s), 20.0 (s), 19.1 (s), 19.0 (s), 18.7 (s), 18.4 (s), 14.0 (s), carbonyl and cyano carbons not observed. IR (solid-state, $\left.\mathrm{cm}^{-1}\right)$ : $3260\left(\mathrm{U}_{\mathrm{NH}}\right), 2071\left(\mathrm{U}_{\mathrm{CN}}\right) 1897\left(\mathrm{U}_{\mathrm{CO}}, \mathrm{U}_{\mathrm{FeH}}\right)$.

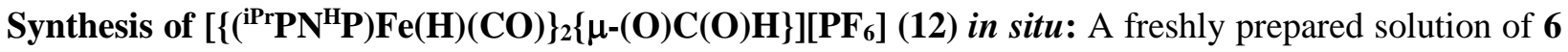
(8.3 mg, 0.016 mmols) in $\mathrm{C}_{6} \mathrm{D}_{6}(250 \mu \mathrm{L})$ was added to a J. Young NMR tube. To this, a freshly prepared solution of $\mathbf{1 0}(6.0 \mathrm{mg}, 0.014 \mathrm{mmols})$ in $\mathrm{C}_{6} \mathrm{D}_{6}(250 \mu \mathrm{L})$ was added. The J. Young was immediately capped. Crystals suitable for $\mathrm{x}$-ray diffraction were grown by vacuum transferring $c a .500 \mu \mathrm{L}$ of degassed pentane 
to this sample while frozen and thawing the sample while undisturbed, allowing for slow diffusion of pentane into the $\mathrm{C}_{6} \mathrm{D}_{6}$ solution. Selected NMR peaks: ${ }^{1} \mathrm{H}$ NMR $\left(500 \mathrm{MHz}, \mathrm{C}_{6} \mathrm{D}_{6}, \delta\right): 8.23(\mathrm{~s}, 1 \mathrm{H}, \mathrm{OC}(\mathrm{O}) H)$, $-25.66\left(\mathrm{t}, J^{2}{ }_{\mathrm{H}-\mathrm{P}}=53.8 \mathrm{~Hz}, 2 \mathrm{H}, \mathrm{Fe} H\right) .{ }^{31} \mathrm{P}\left\{{ }^{1} \mathrm{H}\right\} \mathrm{NMR}\left(202 \mathrm{MHz}, \mathrm{C}_{6} \mathrm{D}_{6}, \delta\right): 90.8$ (s). IR (solution state in $\mathrm{C}_{6} \mathrm{D}_{6}$,

$\left.\mathrm{cm}^{-1}\right): 1900\left(\mathrm{U}_{\mathrm{CO}, \text { carbonyl }}\right), 1588$ ( $\mathrm{U}_{\mathrm{CO}}$, formate). Opening the J. Young to an $\mathrm{N}_{2}$ atmosphere in a glovebox or exposing the solution to vacuum resulted in rapid conversion of the sample to an intractable mixture of products, precluding isolation.

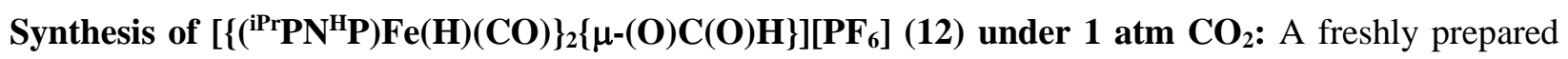
solution of 6 (5.0 mg, $0.0093 \mathrm{mmols})$ in $\mathrm{C}_{6} \mathrm{D}_{6}(250 \mu \mathrm{L})$ was added to a J. Young NMR tube and frozen in the cold well of a glovebox. To this, a freshly prepared solution of $\mathbf{1 0}(3.6 \mathrm{mg}, 0.0083 \mathrm{mmols})$ in $\mathrm{C}_{6} \mathrm{D}_{6}(200$ $\mu \mathrm{L}$ ) was added and the second layer of solvent allowed to freeze. The J. Young was immediately capped, removed from the glovebox, and placed in a cold bath at $-78{ }^{\circ} \mathrm{C}$. While kept in the cold bath, the J. Young tube was attached to a Schlenk line and the $\mathrm{N}_{2}$ headspace was removed. The J. Young was removed from the cold bath and the headspace immediately filled with 1 atm of $\mathrm{CO}_{2}$. The sample was then allowed to thaw and the solution was inverted several times to ensure adequate liquid-gas mixing before spectral acquisition. Performing this reaction under a $\mathrm{CO}_{2}$ atmosphere drastically decreases the rate of decomposition. After 96 hours in solution, only $8 \%$ decomposition to 4 and free ${ }^{{ }^{\mathrm{Pr}} \mathrm{PN}}{ }^{\mathrm{H}} \mathrm{P}$ ligand was observed. When the same reaction is performed in an $\mathrm{N}_{2}$ atmosphere, full decomposition occurs on this time frame. 


\section{Reaction of 6 with 1}

Reaction of 1 with 6: A sample of 6 ( $7.2 \mathrm{mg}, 0.013 \mathrm{mmols})$ was dissolved in $250 \mu \mathrm{L}$ of $\mathrm{C}_{6} \mathrm{D}_{6}$ and transferred to a J Young NMR tube. Then, a solution of $\mathbf{1}\left(5.4 \mathrm{mg}, 0.014\right.$ mmols) was prepared with $250 \mu \mathrm{L}$ of $\mathrm{C}_{6} \mathrm{D}_{6}$ and subsequently transferred to the J Young NMR tube containing the solution of $\mathbf{6}$. No visible color change was observed, and the tube was immediately capped. ${ }^{1} \mathrm{H}$ and ${ }^{31} \mathrm{P}$ NMR spectra indicated the presence of both 6 and 1 in solution, with minor growth (13\%) of peaks in both spectra corresponding to 4 over $c a .4$ hours. 


\section{Titration of 1 with 2,6-lutidinium $B A r^{F}$ for $p K_{a}$ Determination}

A stock solution of 1 in THF $(1.00 \mathrm{mM}, 3.00 \mathrm{~mL})$ was prepared and transferred to a cuvette. The top of the cuvette was sealed with a red rubber septum and removed from the glovebox. An additional stock solution of 2,6-lutidium $\mathrm{BAr}_{4} \mathrm{in}_{\mathrm{THF}}(3.00 \mathrm{mM}, 500 \mu \mathrm{L})$ was prepared and transferred to a Hamilton SampleLock gas-tight locking syringe. After taking an initial UV-Vis absorption spectrum of the solution in the cuvette, the syringe was pierced through the septum. The stock solution of 2,6-lutidium $\mathrm{BAr}_{4}{ }_{4}$ was added to the cuvette in $25.0 \mu \mathrm{L}$ aliquots ( 0.25 equiv. relative to $\mathbf{1})$, with the cuvette being shaken and another spectrum taken after each aliquot. The disappearance of the absorbance at $522 \mathrm{~nm}$ was monitored to determine the concentration of $\mathbf{1}\left(\varepsilon=900 \mathrm{M}^{-1} \mathrm{~cm}^{-1}\right)^{7}$ and the concentration of all other reagents was assumed on the basis of mass balance, providing a measure of $\mathrm{K}_{\mathrm{eq}}$ of the reaction. The difference in $\mathrm{pK}_{\mathrm{a}}$ of the resultant complex relative to 2,6-lutidinium $\mathrm{BAr}_{4}{ }_{4}$ was calculated to be $0.48 \mathrm{pK}_{\mathrm{a}}$ units, corresponding to a $\mathrm{pK}_{\mathrm{a}}$ of $\mathbf{5 - T H F}$ of 8.2. ${ }^{8}$
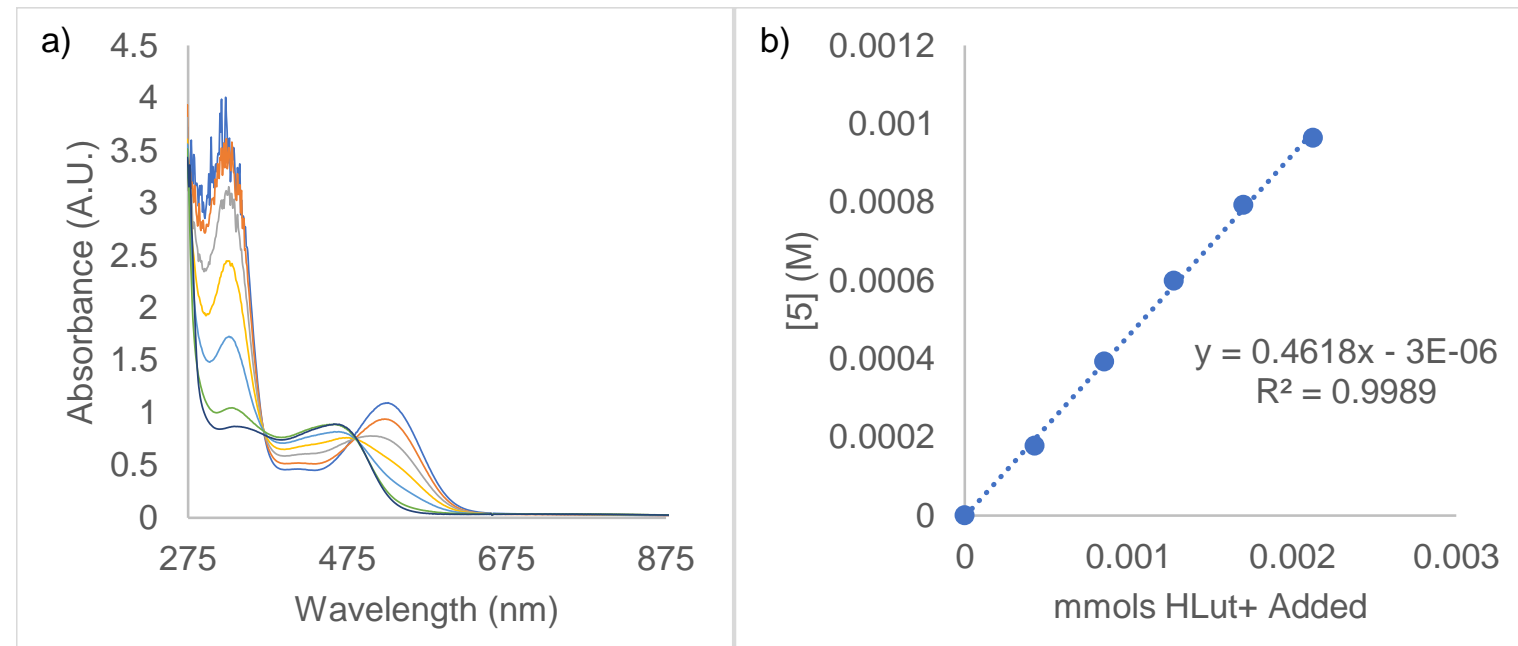

Figure S13: Titration data for the determination of the $\mathrm{pK}_{\mathrm{a}}$ difference between lutidinium and $\mathbf{5}$ including a) UV-Vis spectra used for determination of $\mathrm{K}_{\mathrm{eq}}$ and b) plot of concentration of $\mathbf{5}$ and amount of HLut ${ }^{+}$. 


\section{Experiments to Probe Phosphine Bonding}

General Procedure: A sample of $6(5 \mathrm{mg}, 0.009$ mmols $)$ was dissolved in $\mathrm{C}_{6} \mathrm{D}_{6}(c a .450 \mu \mathrm{L})$. To this sample, 1 equiv. of the ligand (0.009 mmols) was added. Upon addition of the phosphine, samples that exhibited binding were observed to change in color from orange to yellow. Samples that did not give spectroscopic evidence of binding remained orange. Whether or not a phosphine ligand bound was assessed using the ${ }^{31} \mathrm{P}\left\{{ }^{1} \mathrm{H}\right\}$ NMR and the splitting of the hydride peak in the ${ }^{1} \mathrm{H}$ NMR spectrum, which upon binding becomes a doublet of triplets. A plot of the ${ }^{1} \mathrm{H}$ NMR spectra from reactions with different phosphines is shown in Figure S14.
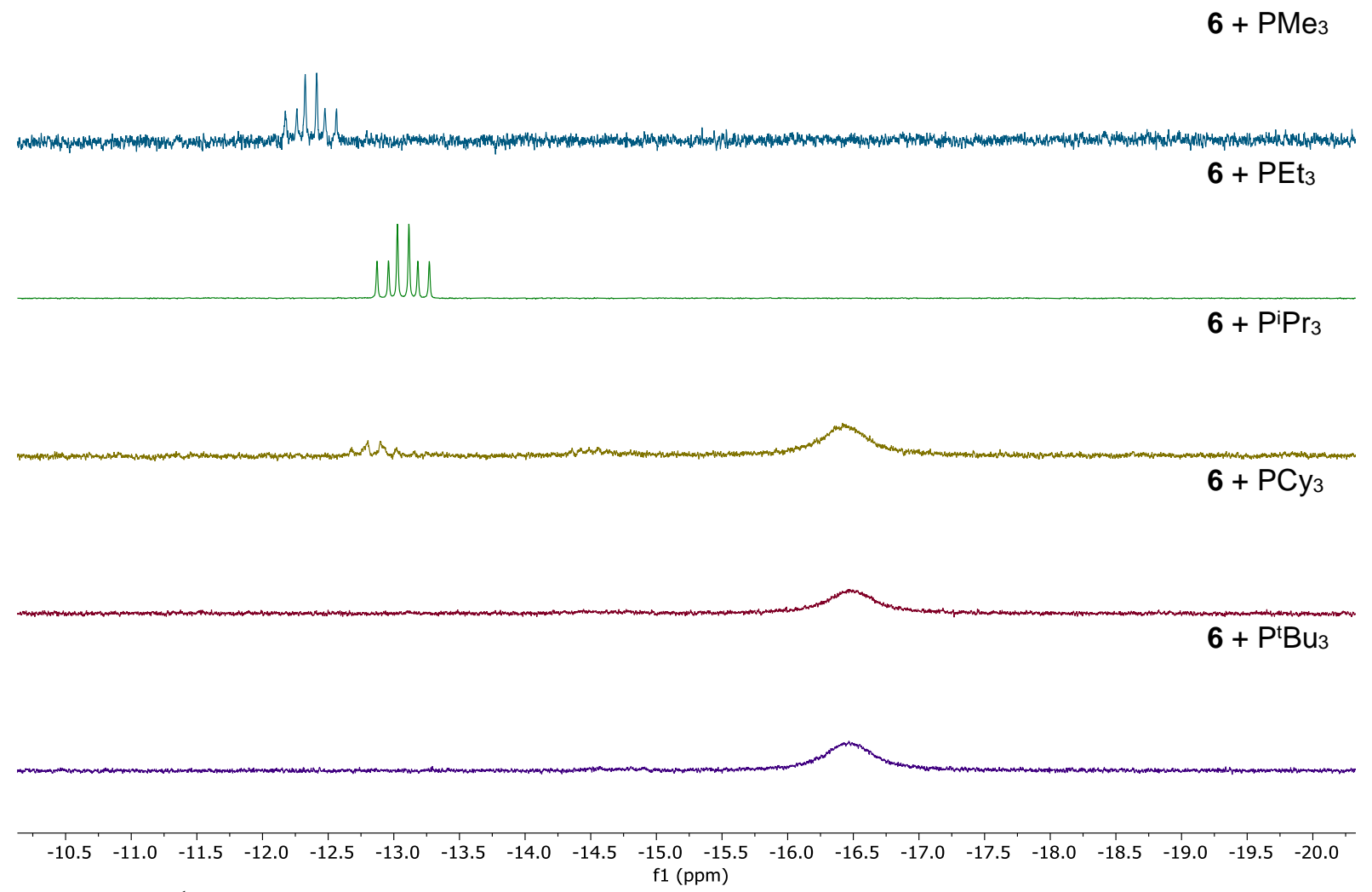

Figure S14. ${ }^{1} \mathrm{H}$ NMR of 6 and various phosphine ligands $\left(\mathrm{PR}_{3}\right)$ in $\mathrm{C}_{6} \mathrm{D}_{6}$ to evaluate phosphine binding on the basis of the hydride shift and splitting pattern. $\mathrm{PMe}_{3}$ and $\mathrm{PEt}_{3}$ bind fully to $6 . \mathrm{P}^{\mathrm{i}} \mathrm{Pr}_{3}$ binds transiently. Within the error of the $\mathrm{NMR}$ experiment $\mathrm{PCy}_{3}$ and $\mathrm{P}^{t} \mathrm{Bu}_{3}$ do not appear to bind to 6 . Hydride peak for unreacted $\mathbf{6}$ is observed at $-16.5 \mathrm{ppm}$.

Synthesis of $\left[\left({ }^{\mathrm{iPr}} \mathbf{P N}{ }^{\mathrm{H}} \mathbf{P}\right) \mathbf{F e}(\mathbf{H})(\mathbf{C O})\left(\mathbf{P E t}_{3}\right)\right]\left[\mathbf{P F}_{6}\right]$ : A sample of $\mathbf{1}$ (20 mg, $\left.0.050 \mathrm{mmols}\right)$ and 2,6-lutidinium hexafluorophosphate $(13 \mathrm{mg}, 0.050 \mathrm{mmols})$ were dissolved in THF (ca. $5 \mathrm{~mL})$, generating an orange 
solution indicating the formation of $\mathbf{6}$. To this solution, triethylphosphine ( $8.0 \mu \mathrm{L}, 0.050 \mathrm{mmols})$ was added via syringe. The solution gradually turned yellow over a few minutes and was allowed to sit at room temperature for 30 minutes. The solvent was removed in vacuo and the product extracted in $4 \mathrm{~mL}$ benzene. This solution was concentrated to $\sim 2 \mathrm{~mL}$, layered with $2 \mathrm{~mL}$ pentane, and left at room temperature for 24 h. The solvent was decanted and the solid dried in vacuo to afford the product as pale yellow block crystals (yield: $27.7 \mathrm{mg}, 83 \%) .{ }^{1} \mathrm{H}$ NMR (400 MHz, $\mathrm{C}_{6} \mathrm{D}_{6}, \delta$ ): 3.56 (br m, 3H, $\mathrm{NH}$ and $\left.\mathrm{CH}_{2}\right), 1.88\left(\mathrm{~m}, 4 \mathrm{H}, \mathrm{CH}_{2}\right.$ ), $1.72\left(\mathrm{~m}, 2 \mathrm{H}, \mathrm{CH}_{2}\right), 1.45-1.62\left(\mathrm{~m}, 10 \mathrm{H}, \mathrm{P}\left(\mathrm{CH}_{2} \mathrm{CH}_{3}\right)\right.$ and $\left.\mathrm{CH}\left(\mathrm{CH}_{3}\right)_{2}\right), 0.90-1.10\left(\mathrm{~m}, 21 \mathrm{H}, \mathrm{P}\left(\mathrm{CH}_{2} \mathrm{CH}_{3}\right)_{3}\right.$ and $\left.\mathrm{CH}\left(\mathrm{CH}_{3}\right)_{2}\right), 0.83\left(\mathrm{~m}, 6 \mathrm{H}, \mathrm{CH}\left(\mathrm{CH}_{3}\right)_{2}\right), 0.76\left(\mathrm{~m}, 6 \mathrm{H}, \mathrm{CH}\left(\mathrm{CH}_{3}\right)_{2}\right),-13.23 \mathrm{z}\left(\mathrm{dt}, J_{\text {H-P }}^{2}=34.9 \mathrm{~Hz}, 62.2 \mathrm{~Hz}, 1 \mathrm{H}\right.$, $\mathrm{Fe}-H) .{ }^{31} \mathrm{P}\left\{{ }^{1} \mathrm{H}\right\}$ NMR $\left(161 \mathrm{MHz}, \mathrm{C}_{6} \mathrm{D}_{6}, \delta\right): 88.2\left(\mathrm{~d}, J^{2}{ }_{\mathrm{P}-\mathrm{P}}=20.6 \mathrm{~Hz}, 2 \mathrm{P},{ }^{\mathrm{iPr}} P \mathrm{~N}^{\mathrm{H}} P\right), 19.3\left(\mathrm{t}, J^{2}{ }_{\mathrm{P}-\mathrm{P}}=20.6 \mathrm{~Hz}\right.$, 1P, $\left.P \mathrm{Et}_{3}\right),-143.4\left(\mathrm{sept}, J^{l}{ }_{\mathrm{P}-\mathrm{F}}=712.4 \mathrm{~Hz}, P \mathrm{~F}_{6}\right) .{ }^{19} \mathrm{~F}$ NMR $\left(471 \mathrm{MHz}, \mathrm{C}_{6} \mathrm{D}_{6}, \delta\right):-72.0\left(\mathrm{~d}, J_{\mathrm{P}-\mathrm{F}}^{l}=712.4 \mathrm{~Hz}\right.$, P $\left.F_{6}\right) .{ }^{13} \mathrm{C}\left\{{ }^{1} \mathrm{H}\right\}$ NMR $\left(151 \mathrm{MHz}, \mathrm{C}_{6} \mathrm{D}_{6}, \delta\right): 54.3(\mathrm{~s}), 31.6(\mathrm{t}, J=13.8 \mathrm{~Hz}), 30.5(\mathrm{t}, J=13.8 \mathrm{~Hz}), 25.0(\mathrm{td}, J$ = 27.3, 9.9 Hz), $20.9(\mathrm{~s}), 19.8(\mathrm{~s}), 19.4(\mathrm{~s}), 19.2(\mathrm{~s}), 18.4(\mathrm{~s}), 17.4(\mathrm{t}, J=6.9 \mathrm{~Hz}), 7.8(\mathrm{~d}, J=6.9 \mathrm{~Hz})$, carbonyl carbon not observed. IR (solid-state, $\left.\mathrm{cm}^{-1}\right): 3296\left(\mathrm{U}_{\mathrm{NH}}\right), 1902\left(\mathrm{U}_{\mathrm{CN}}, \mathrm{U}_{\mathrm{FeH}}\right) 1867\left(\mathrm{U}_{\mathrm{CO}}, \mathrm{U}_{\mathrm{FeH}}\right)$. 


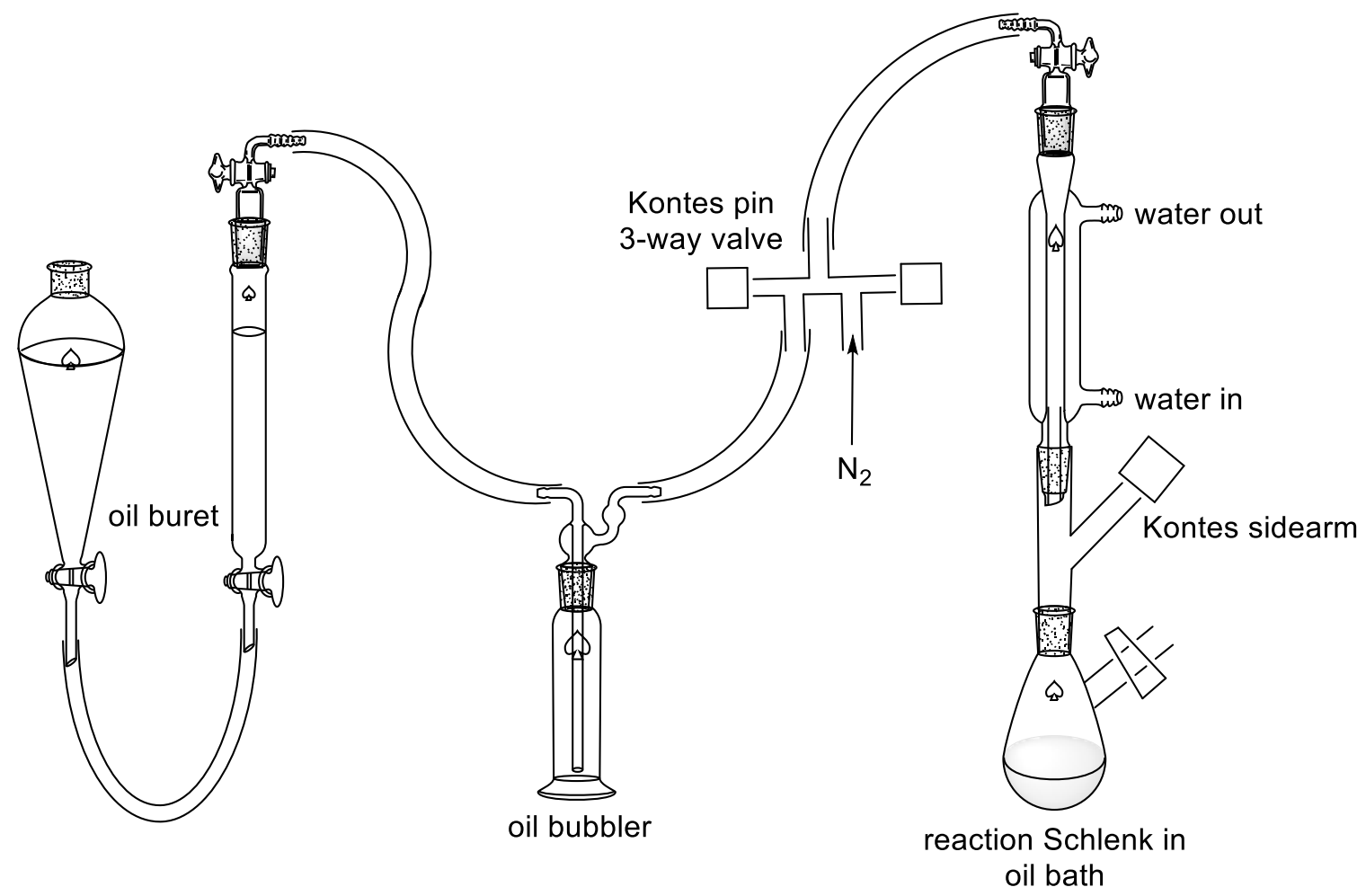

Figure S15. Diagram of experimental setup for formic acid dehydrogenation.

Representative Procedure for Formic Acid Dehydrogenation:

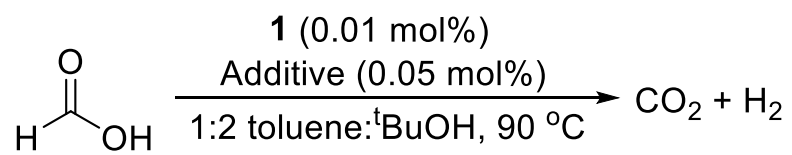

In the glovebox, to a $25 \mathrm{~mL}$ Schlenk flask equipped with a magnetic stir bar were added toluene (1.37 $\mathrm{mL})$ and $1(291 \mu \mathrm{L}$ of a $1.0 \mathrm{mM}$ stock solution in toluene). The flask was sealed, removed from the glovebox, and put under $\mathrm{N}_{2}$ on a Schlenk line. A reflux condenser with a Kontes sidearm for addition of reagents was attached to a Kontes pin 3-way valve via Tygon tubing, thoroughly purged with $\mathrm{N}_{2}$, then attached to the reaction flask. Anhydrous ${ }^{\mathrm{t}} \mathrm{BuOH}(3.33 \mathrm{~mL})$ was added to the reaction flask through a rubber septum placed on the condenser sidearm. The phosphine additive being tested $(0.145 \mathrm{mmol}$, added as a $1 \%$ solution in toluene) was added to the reaction flask in the same way. The Tygon tubing leading from the 3-way valve 
to the oil bubbler was purged with $\mathrm{N}_{2}$, then the bubbler was attached to a gas buret filled with mineral oil to prevent gas dissolution. The reaction flask was lowered into an oil bath preheated to $90{ }^{\circ} \mathrm{C}$ and allowed to equilibrate. Formic acid $(110 \mu \mathrm{L}, 2.91 \mathrm{mmol})$ was added through a rubber septum placed on the condenser sidearm, then the sidearm was rapidly resealed with a Kontes pin, the system was cut off from active $\mathrm{N}_{2}$ flow, and the reaction flask was opened to the gas buret via the 3-way valve. As gas evolution lowered the level of the oil in the buret, the separatory funnel was lowered to keep the oil levels approximately even and maintain roughly atmospheric pressure in the reaction. A second catalytic reaction was always run in parallel and the numbers reported are the average of at least two experiments. Uncertainty is given as $\pm 10 \%$ of the measured turnover number.

\section{TON Quantification:}

Before running a catalytic reaction, a blank reaction was performed in which no catalyst was added to the reaction solution. The volume of gas obtained from this reaction (trace solvent and FA) was recorded as $\mathrm{V}_{\text {blank. }}$ The corrected volume of gas produced from a catalytic reaction was then calculated using the following expression:

$$
V_{\text {corr }}=V_{\text {obs }}-V_{\text {blank }}
$$

Where $\mathrm{V}_{\mathrm{obs}}$ is the observed change in oil level in the gas buret during catalysis. For kinetics experiments, blank reactions were performed where $\mathrm{V}_{\text {blank }}$ was measured at each desired timepoint. It was assumed that a 1:1 mixture of $\mathrm{H}_{2}$ and $\mathrm{CO}_{2}$ was produced in the catalytic reaction. The number of moles of gas produced $\left(\mathrm{n}_{\text {prod }}\right)$ in the reaction was determined using the following expression that utilizes the ideal gas law:

$$
n_{\text {prod }}=\frac{V_{\text {corr }}}{2\left(22.4 \frac{\mathrm{L}}{\mathrm{mol}}\right)}
$$

The TON was then determined using the following expression:

$$
\text { TON }=\frac{n_{\text {prod }}}{n_{\text {cat }}}
$$

Where $\mathrm{n}_{\text {cat }}$ is the molar quantity of the catalyst. 
The TOF was determined to be the TON that occurred in the first hour.

\section{Gas Volume Determination}

The volume/height ratio of each gas buret was determined before using them in catalysis. To do this, water was placed in the buret, and the meniscus was marked. Some water was drained from the column into a tared flask, and the new water level was marked again. The weight of the water drained from the flask was used to determine its volume, and this was divided by the change in height in the buret to determine the $\mathrm{mL} / \mathrm{cm}$ calibration of the buret.

\section{GC Detection of Gaseous Reaction Products}

GC was performed to confirm the products of formic acid dehydrogenation using $\mathbf{1}$ and $\mathrm{PMe}_{3}$ as a 1:1 ratio of $\mathrm{CO}_{2}$ and $\mathrm{H}_{2}$ with no observable $\mathrm{CO}$ generation. A standard catalytic reaction was run in order to ensure the desired gaseous products were being formed. GC samples were taken from the headspace of the gas buret. The GC trace is shown in Figure S16. No CO formation was observed (retention time 7 minutes).

$$
\mathrm{H}_{\mathrm{OH}} \frac{\begin{array}{c}
1(0.1 \mathrm{~mol} \%) \\
\mathrm{PMe}_{3}(0.5 \mathrm{~mol} \%)
\end{array}}{1: 2 \text { toluene: }{ }^{\mathrm{B}} \mathrm{BuOH}, 90^{\circ} \mathrm{C}} \mathrm{CO}_{2}+\mathrm{H}_{2}
$$

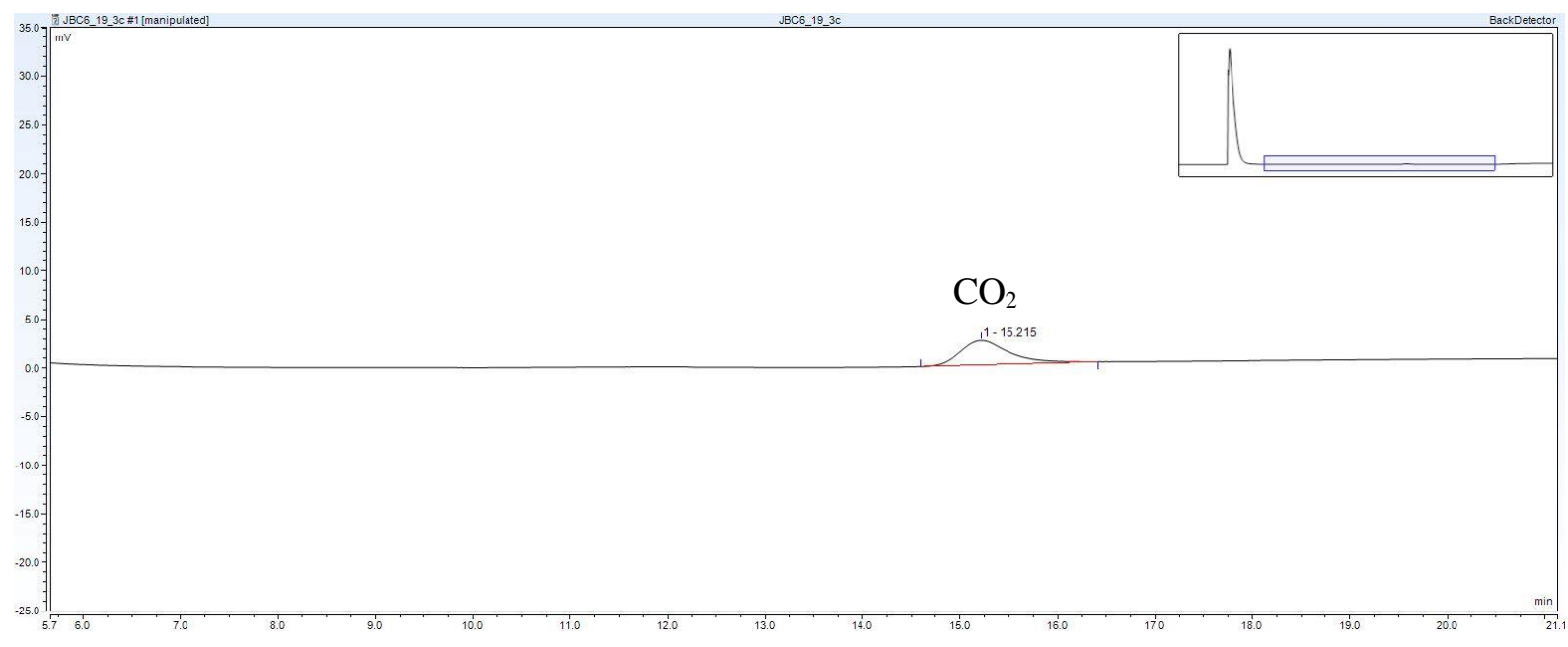

Figure S16. GC trace of $\mathrm{CO}_{2}$ detection using He carrier gas; no $\mathrm{CO}$ peak observed. Large peak in inset spectrum is $\mathrm{N}_{2} /$ solvent vapor. 


\section{Determination of Catalysis Decomposition Product}

Without PMe 3 : In a glovebox, to a J. Young NMR tube were added 1 (1.4 mg, $3.6 \mu$ mol $)$, toluene-d $\mathrm{d}_{8}(0.200$ $\mathrm{mL}),{ }^{\mathrm{t}} \mathrm{BuOH}(0.400 \mathrm{~mL})$ and formic acid $(14 \mu \mathrm{L}, 0.36 \mathrm{mmol})$. The reaction color turned bright yellow upon addition of formic acid, and gas formation was observed. The reaction mixture was frozen in liquid $\mathrm{N}_{2}$, degassed, and sealed under vacuum, then heated to $90{ }^{\circ} \mathrm{C}$. The solution color slowly bleached to colorless and an off-white precipitate formed. Spectroscopic data taken after one hour is shown in Figure S17. Only decomposition products ( 4 and free $\left.{ }^{\mathrm{iPr}} \mathrm{PN}{ }^{\mathrm{H}} \mathrm{P}\right)$ are observed.

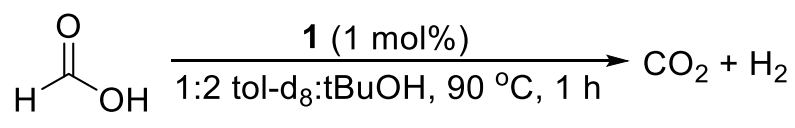

$$
\text { ํㅜ용 }
$$

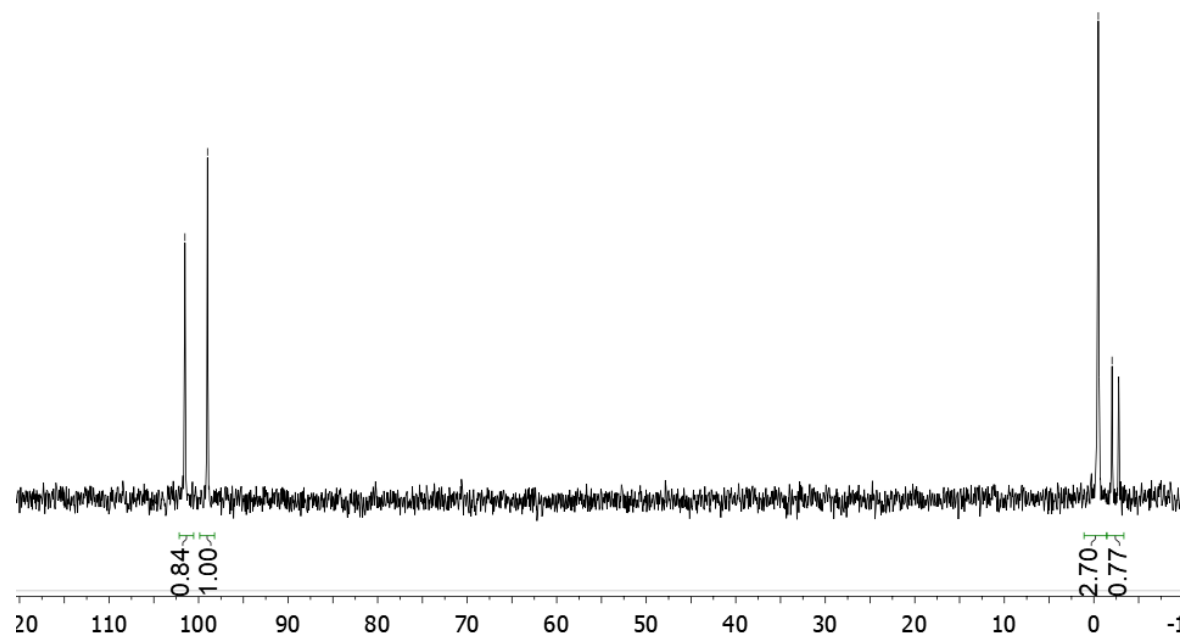

Figure S17. In situ ${ }^{31} \mathrm{P}\left\{{ }^{1} \mathrm{H}\right\}$ NMR of formic acid dehydrogenation using 1 after 1 hour. 4 present as two isomers at 99.00 and $101.53 \mathrm{ppm},{ }^{\mathrm{i} P} \mathrm{PN}^{\mathrm{H}} \mathrm{P}$ observed at $-0.50 \mathrm{ppm}$.

With PMe PM $_{3}$ In a glovebox, to a J Young NMR tube were added $1(1.4 \mathrm{mg}, 3.6 \mu \mathrm{mol}), \mathrm{PMe}_{3}(1.8 \mu \mathrm{L}, 18$ $\mu \mathrm{mol})$ toluene- $\mathrm{d}_{8}(0.200 \mathrm{~mL}), \mathrm{tBuOH}(0.400 \mathrm{~mL})$ and formic acid $(14 \mu \mathrm{L}, 0.36 \mathrm{mmol})$. The reaction color turned bright yellow upon addition of formic acid, and vigorous gas formation was observed. The reaction mixture was frozen in liquid $\mathrm{N}_{2}$, degassed, and sealed under vacuum, then heated to $90{ }^{\circ} \mathrm{C}$. The solution color very slowly lightened. Spectroscopic data taken after one hour is shown in Figure S18. Decomposition 
products $\left(4\right.$ and free $\left.{ }^{i \mathrm{Pr}} \mathrm{PN}{ }^{\mathrm{H}} \mathrm{P}\right)$ account for $56 \%$ of the ${ }^{31} \mathrm{P}$-containing species (discounting free $\mathrm{PMe}_{3}$ ). The remainder of the Fe species is $\mathbf{7}$. Along with confirming the catalyst decomposition product, this experiment also supports our hypothesis that $\mathrm{PMe}_{3}$ decreases the rate of catalyst decomposition.
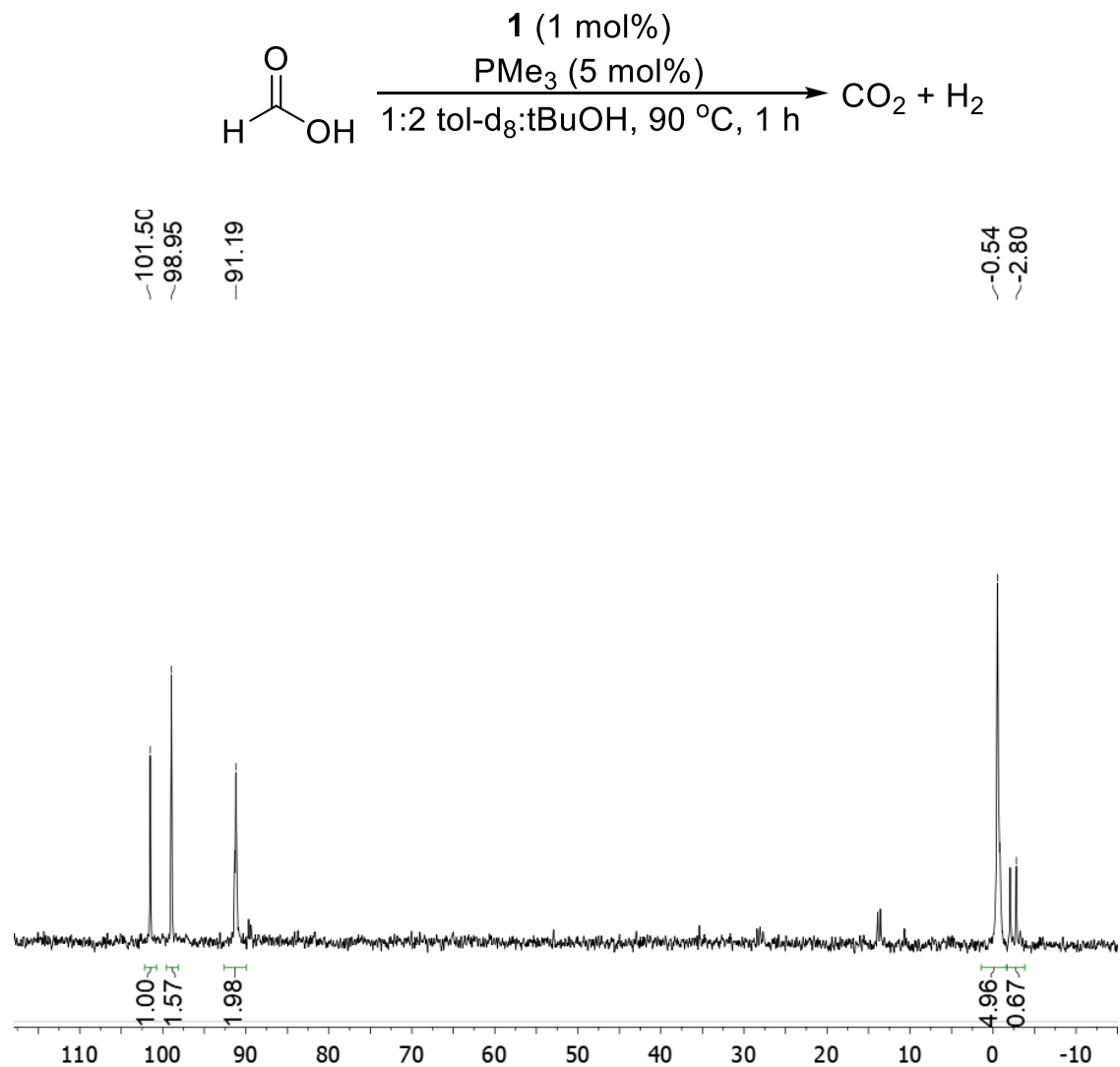

Figure S18. In situ ${ }^{31} \mathrm{P}\left\{{ }^{1} \mathrm{H}\right\}$ NMR of formic acid dehydrogenation using 1 and $\mathrm{PMe}_{3}$ after 1 hour. 4 present as two isomers at 98.95 and $101.50 \mathrm{ppm}$, ${ }^{\mathrm{iPr}} \mathrm{PN}^{\mathrm{H}} \mathrm{P}$ observed at $-0.54 \mathrm{ppm}$, overlapping with free $\mathrm{PMe}_{3} .7$ observed at $91.19 \mathrm{ppm}$ and accounts for $44 \%$ of Fe present. 


\section{NMR and IR Spectra for New Compounds}

\section{Compound 5- $\mathrm{N}_{2}$}

${ }^{1} \mathrm{H}$ and ${ }^{31} \mathrm{P}\left\{{ }^{1} \mathrm{H}\right\}$ NMR spectra at 25 and $-60{ }^{\circ} \mathrm{C}$ and the solution state IR spectrum of the protonation of 1 with HLutBAr $\mathrm{F}_{4}$ in $\mathrm{Et}_{2} \mathrm{O}$ are shown in Figures S19-S21. Protonation using Brookhart's Acid yields the same mixture of products. The room temperature spectra show a mixture of products including peaks corresponding to two isomers of $\left({ }^{\mathrm{iPr}} \mathrm{PN}{ }^{\mathrm{H}} \mathrm{P}\right) \mathrm{Fe}(\mathrm{H})(\mathrm{CO})\left(\mathrm{N}_{2}\right)\left(\mathbf{5}-\mathrm{N}_{2}\right)$ and a few minor unidentified products. DFT calculations (see main paper), the X-ray structure of 5-N2 and the similarity of the hydride chemical shifts indicate that these two isomers correspond to the $\mathrm{N}_{2}$ ligand oriented trans to the hydride and either syn (major isomer) or anti (minor isomer) to the $\mathrm{N}-\mathrm{H}$ moiety. Upon cooling to $-60{ }^{\circ} \mathrm{C}$, the spectra of $\mathbf{5 - N _ { 2 }}$ sharpen, and the other species decrease in intensity, indicating stronger $\mathrm{N}_{2}$ binding.

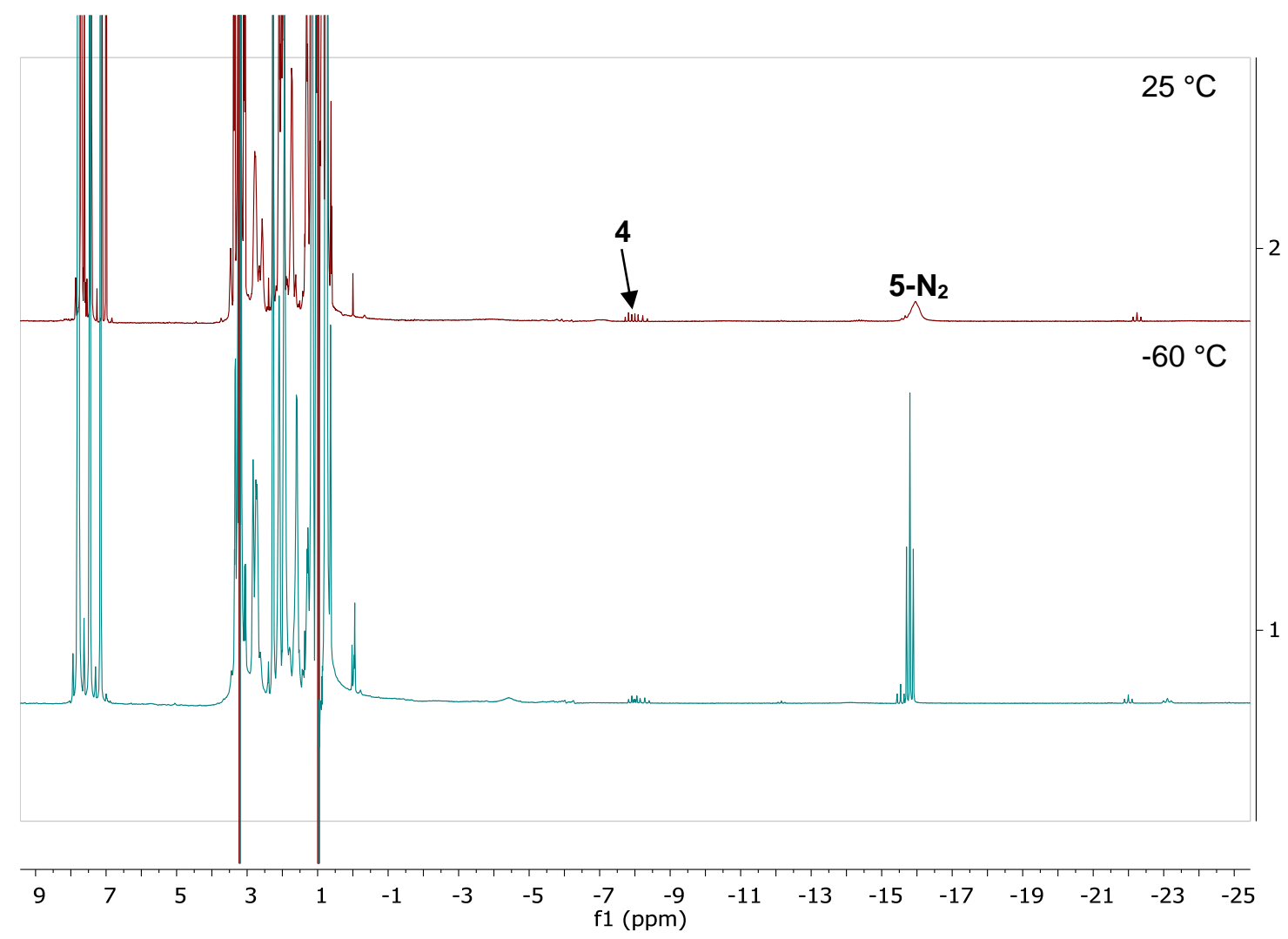

Figure S19. ${ }^{1} \mathrm{H}$ NMR spectra from the protonation of $\mathbf{1}$ with $\mathrm{HLutBAr}{ }_{4}$ to generate $\mathbf{5}-\mathbf{N}_{\mathbf{2}}, \mathbf{4}$, and some minor unidentified complexes in $\mathrm{Et}_{2} \mathrm{O}$ at 25 and $-60{ }^{\circ} \mathrm{C}$. 

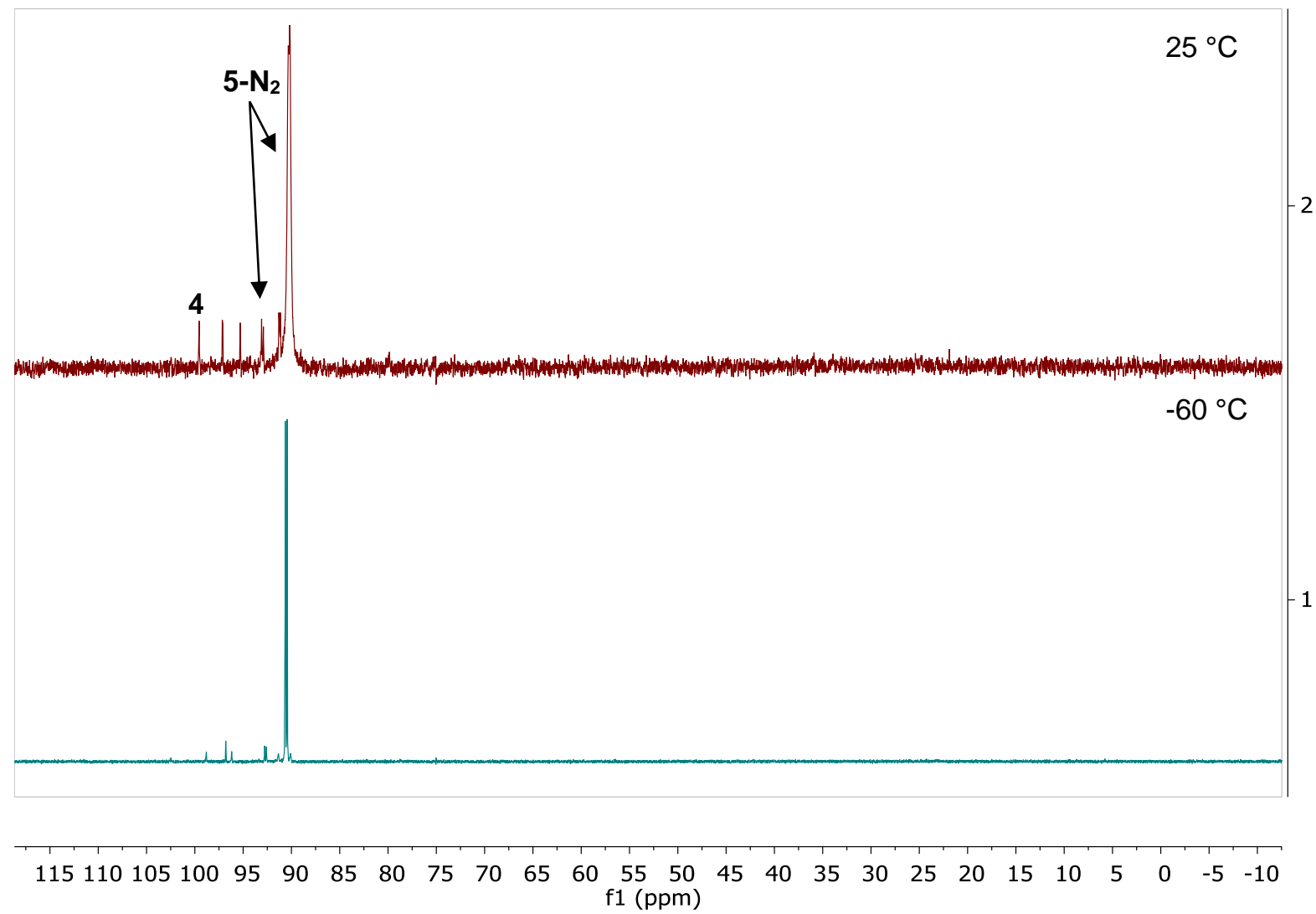

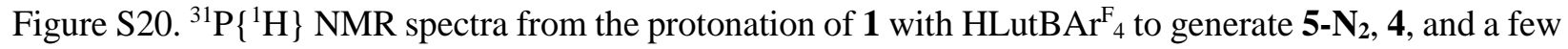
minor unidentified complexes in $\mathrm{Et}_{2} \mathrm{O}$ at 25 and $-60{ }^{\circ} \mathrm{C}$. 


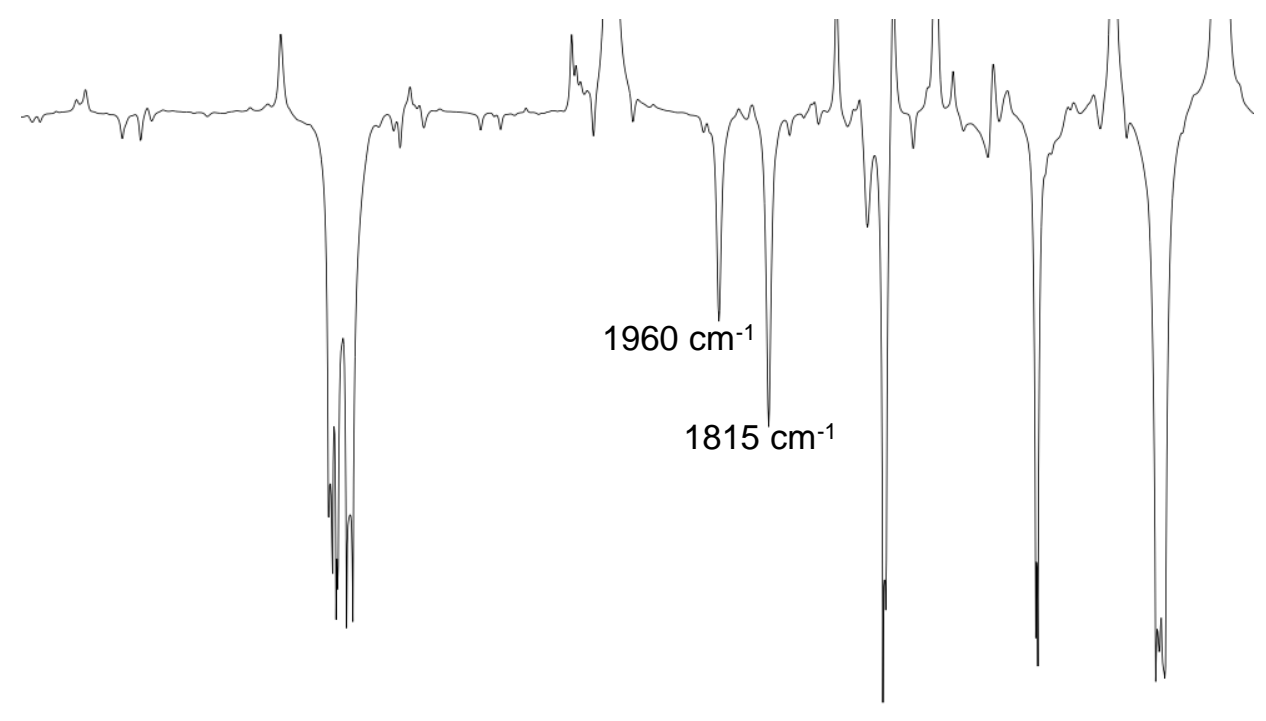

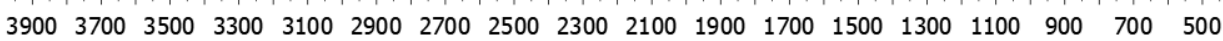

Figure S21. Solution-state IR spectrum of $\left({ }^{\mathrm{iPr} P N} \mathrm{HP}\right) \mathrm{Fe}(\mathrm{H})(\mathrm{CO})\left(\mathrm{N}_{2}\right) \quad\left(\mathbf{5}-\mathrm{N}_{2}\right)$. Background spectrum taken of $\mathrm{C}_{6} \mathrm{D}_{6}$ solvent and subtracted from sample spectrum, leading to negative peaks in baseline. 1960 (UCO), 1815 (UNN). 


\section{Compound 5-THF}

${ }^{1} \mathrm{H}$ and ${ }^{31} \mathrm{P}\left\{{ }^{1} \mathrm{H}\right\}$ NMR spectra at 0,25 , and $50{ }^{\circ} \mathrm{C}$ of 5-THF are shown below in Figures S22-S23. These spectra contain small amounts of $\mathbf{5}-\mathbf{N}_{2}$ at lower temperatures (none observed at $50{ }^{\circ} \mathrm{C}$ ), and several other small impurities. The peaks corresponding to 5-THF sharpen at lower temperatures, indicating tighter binding of THF. Only one isomer of 5-THF is observed at all temperatures, which agrees with the energies calculated for these complexes (see main paper). We propose based on these calculations that the THF ligand is oriented trans to the hydride and syn to the N-H moiety.

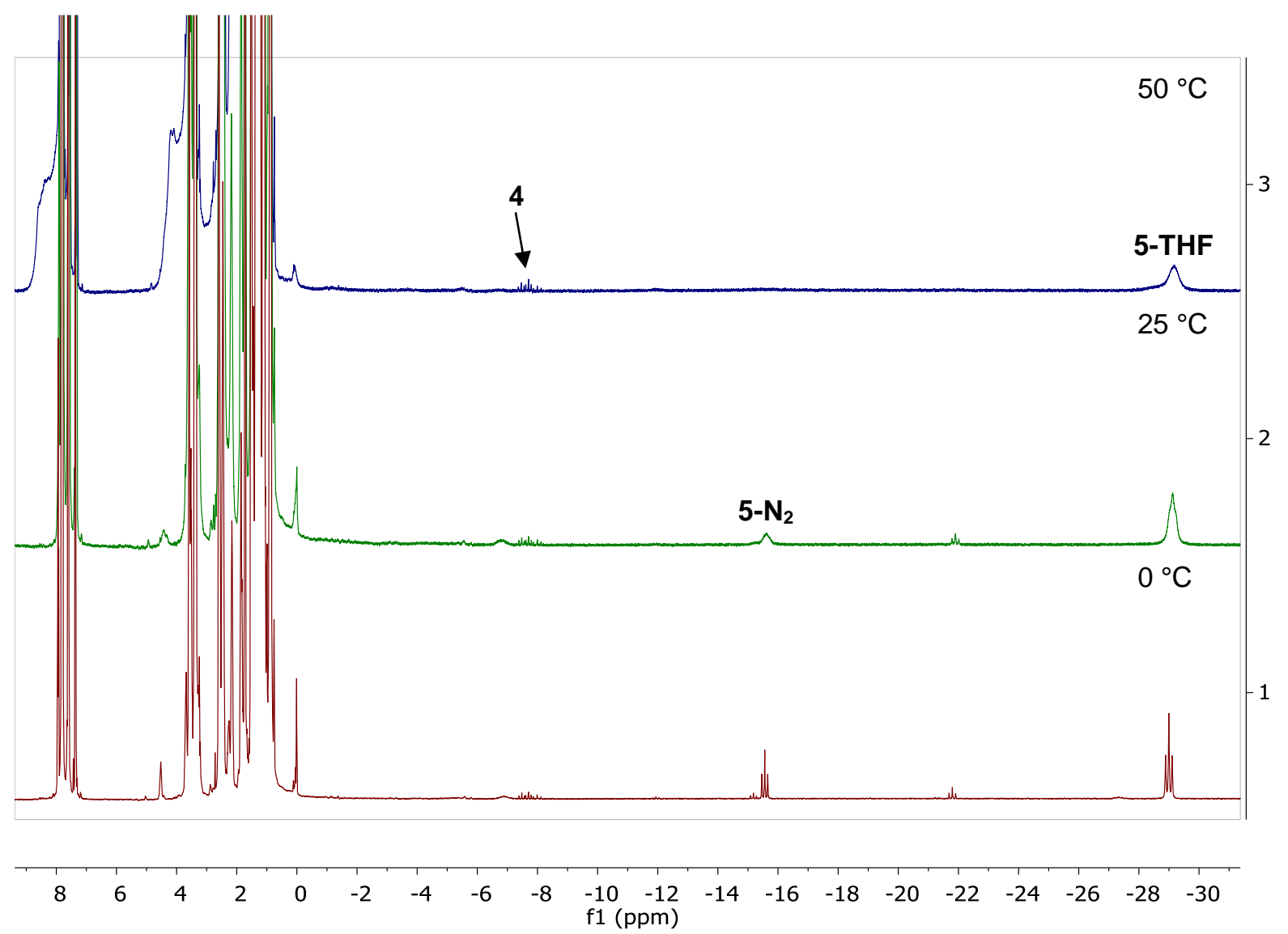

Figure S22. ${ }^{1} \mathrm{H}$ NMR spectra of 5-THF, 5-N2, 4, and other minor unidentified complexes in THF- $\mathrm{d}_{8}$ at 50, 25 , and $0{ }^{\circ} \mathrm{C}$. 


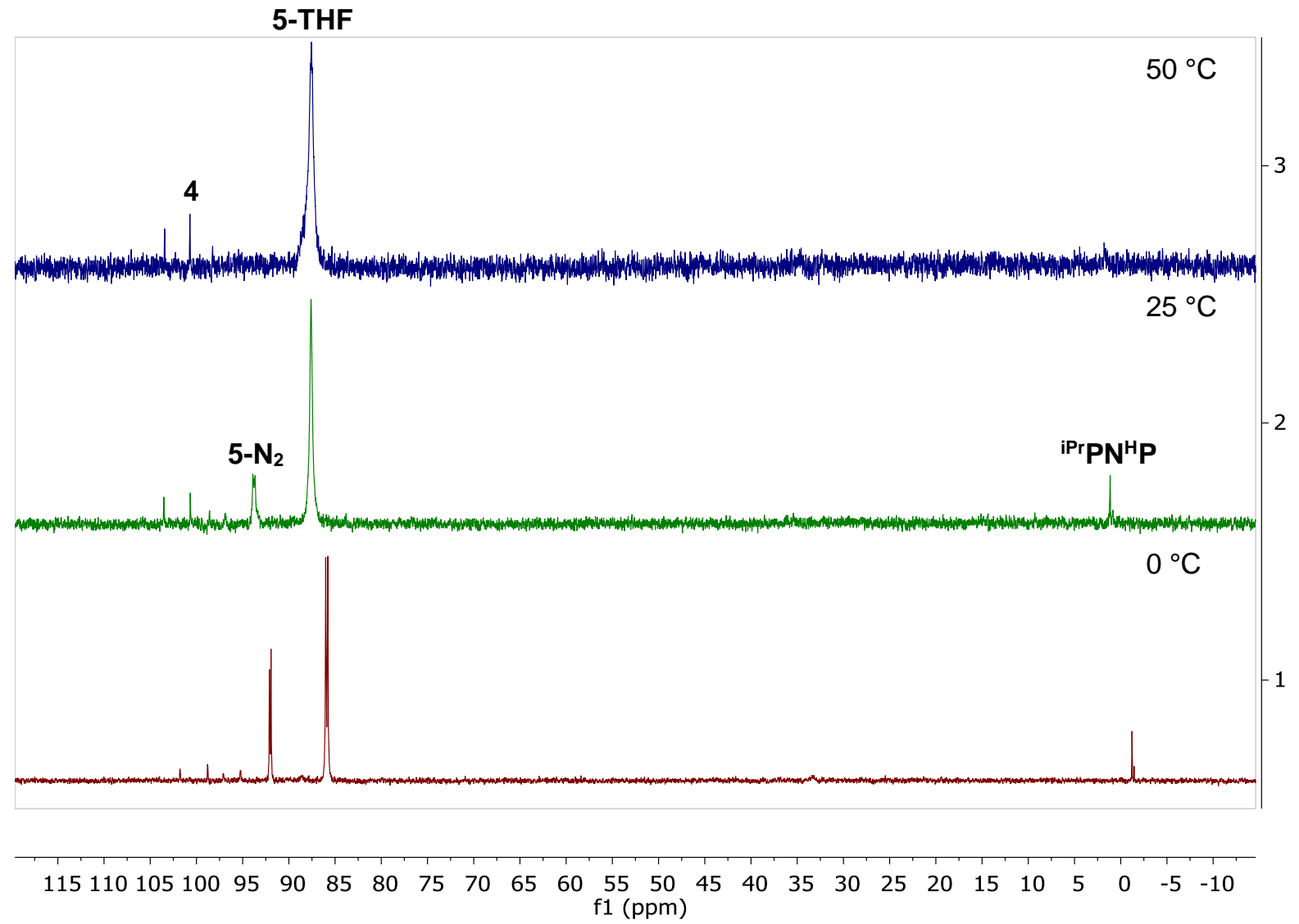

Figure S23. ${ }^{31} \mathrm{P}\left\{{ }^{1} \mathrm{H}\right\}$ NMR spectra of $\mathbf{5 - T H F}, \mathbf{5}-\mathbf{N}_{\mathbf{2}}, \mathbf{4}$, and other minor unidentified complexes in THF-d 8 at 50,25 , and $0{ }^{\circ} \mathrm{C}$. 


\section{Compound 6}

Characterizing data for 6 are shown in Figures S24-S29, including ${ }^{1} \mathrm{H},{ }^{31} \mathrm{P}\left\{{ }^{1} \mathrm{H}\right\}$, and ${ }^{19} \mathrm{~F}$ spectra at room temperature, variable temperature ${ }^{1} \mathrm{H}$ and ${ }^{31} \mathrm{P}\left\{{ }^{1} \mathrm{H}\right\}$ NMR data, and the solid-state $\mathrm{IR}$ spectrum. In some spectra a small amount of $\mathbf{4}(<5 \%)$ is present due to the solution instability of this complex. This decomposition product was commonly (but not always) observed in small quantities even after multiple crystallizations of the desired product but did not appear to impact the reactivity of $\mathbf{6}$. The variable temperature NMR spectra of $\mathbf{6}$ show that $\mathrm{PF}_{6}$ binding is fluxional at room temperature, but the increased sharpness of the ${ }^{1} \mathrm{H}$ and ${ }^{31} \mathrm{P}$ NMR peaks below $0{ }^{\circ} \mathrm{C}$ suggests tighter $\mathrm{PF}_{6}$ binding with hindered free rotation between the $\mathrm{F}$ atom bound to iron.

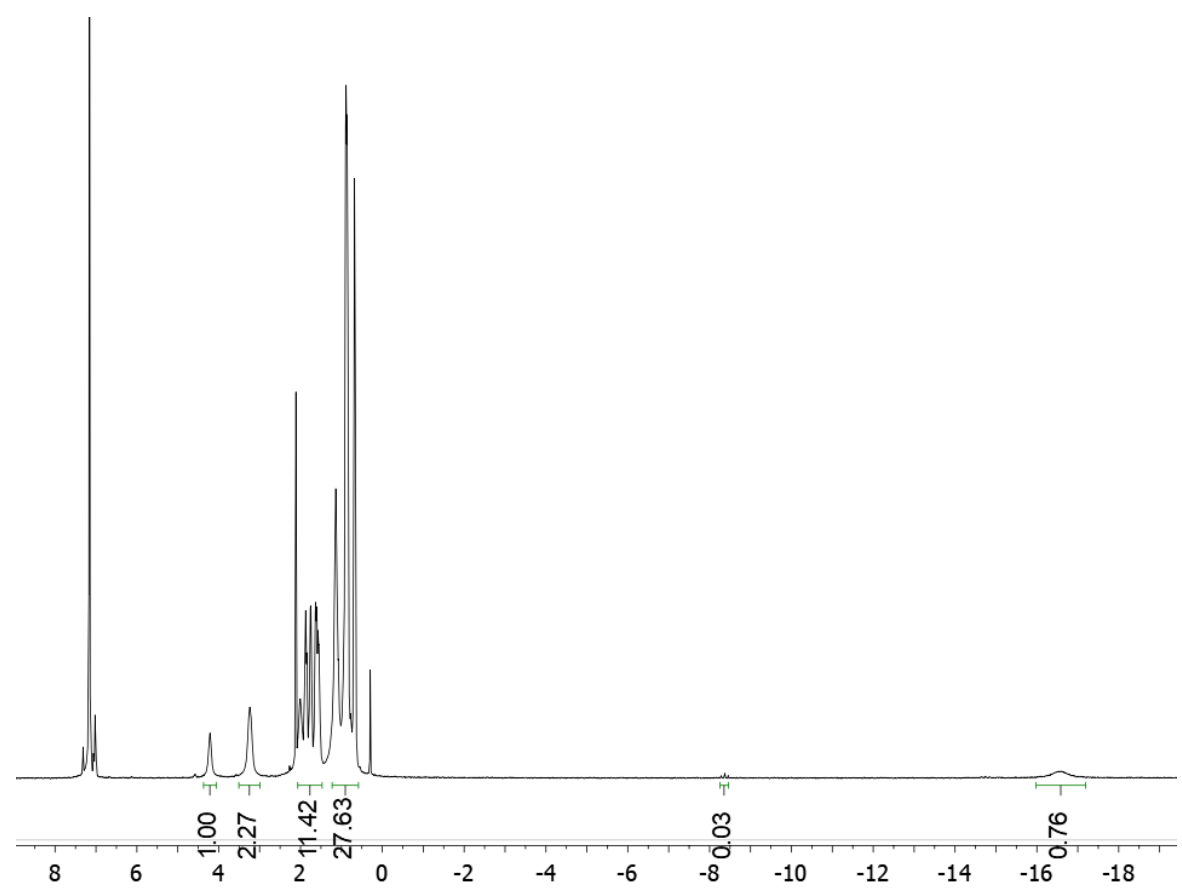

Figure S24. ${ }^{1} \mathrm{H}$ NMR of $\left({ }^{\mathrm{iPr}} \mathrm{PN}{ }^{\mathrm{H}} \mathrm{P}\right) \mathrm{Fe}(\mathrm{H})(\mathrm{CO})\left(\mathrm{PF}_{6}\right)(\mathbf{6})$ in $\mathrm{C}_{6} \mathrm{D}_{6}$ at room temperature, with a $3 \%$ impurity of $\mathbf{4}$ at approximately $-8.0 \mathrm{ppm}$. 


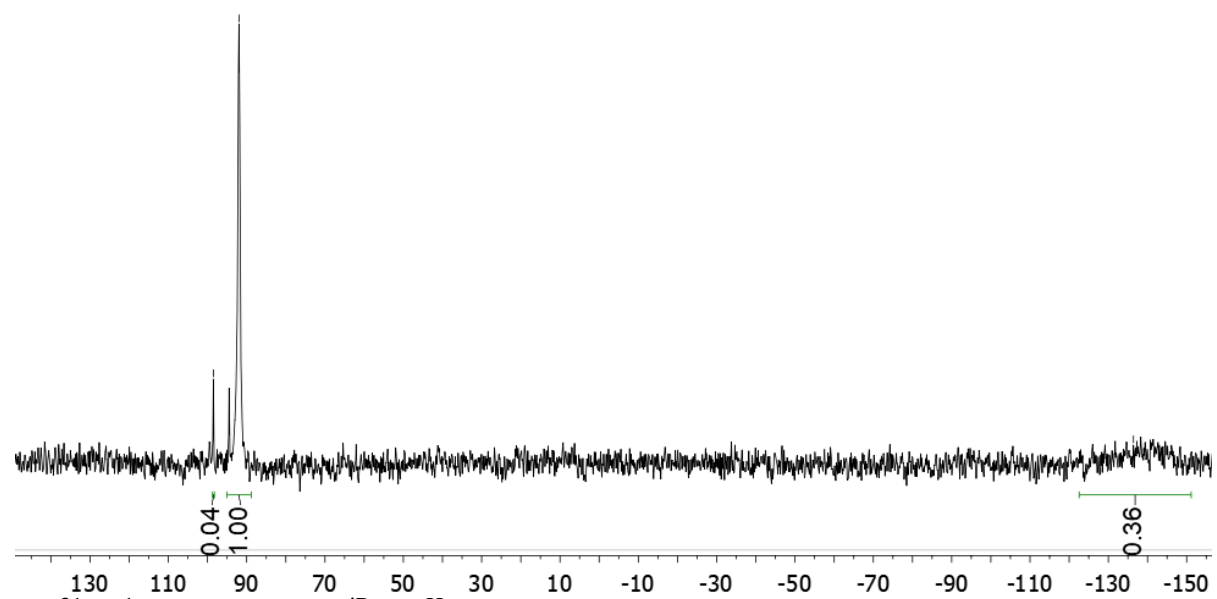

Figure S25. ${ }^{31} \mathrm{P}\left\{{ }^{1} \mathrm{H}\right\}$ NMR of $\left({ }^{i \mathrm{Pr}} \mathrm{PN}^{\mathrm{H}} \mathrm{P}\right) \mathrm{Fe}(\mathrm{H})(\mathrm{CO})\left(\mathrm{PF}_{6}\right)(6)$ in $\mathrm{C}_{6} \mathrm{D}_{6}$ at room temperature, with a $4 \%$ impurity of $\mathbf{4}$ at 98.49 ppm.

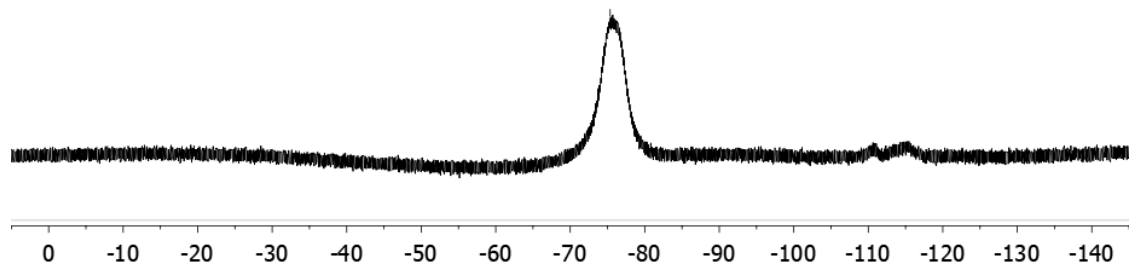

Figure S26. ${ }^{19} \mathrm{~F}$ NMR of $\left({ }^{\mathrm{iPr}} \mathrm{PN}{ }^{\mathrm{H}} \mathrm{P}\right) \mathrm{Fe}(\mathrm{H})(\mathrm{CO})\left(\mathrm{PF}_{6}\right)(6)$ in $\mathrm{C}_{6} \mathrm{D}_{6}$ at room temperature. 

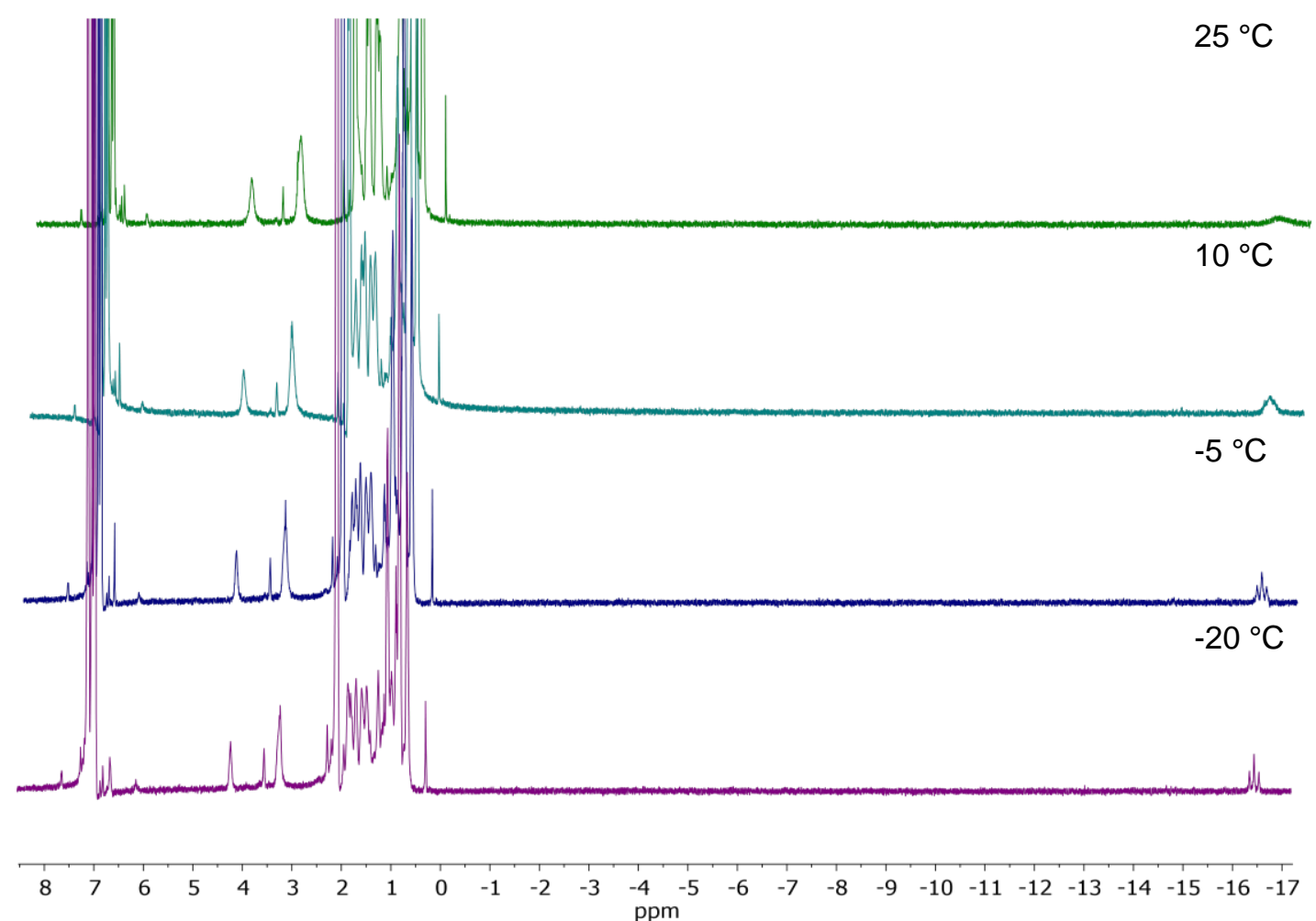

Figure S27. Variable-temperature ${ }^{1} \mathrm{H}$ NMR spectra of $\left({ }^{\mathrm{iPr}} \mathrm{PN}{ }^{\mathrm{H}} \mathrm{P}\right) \mathrm{Fe}(\mathrm{H})(\mathrm{CO})\left(\mathrm{PF}_{6}\right)(6)$ in $\mathrm{d}_{8}$ toluene.

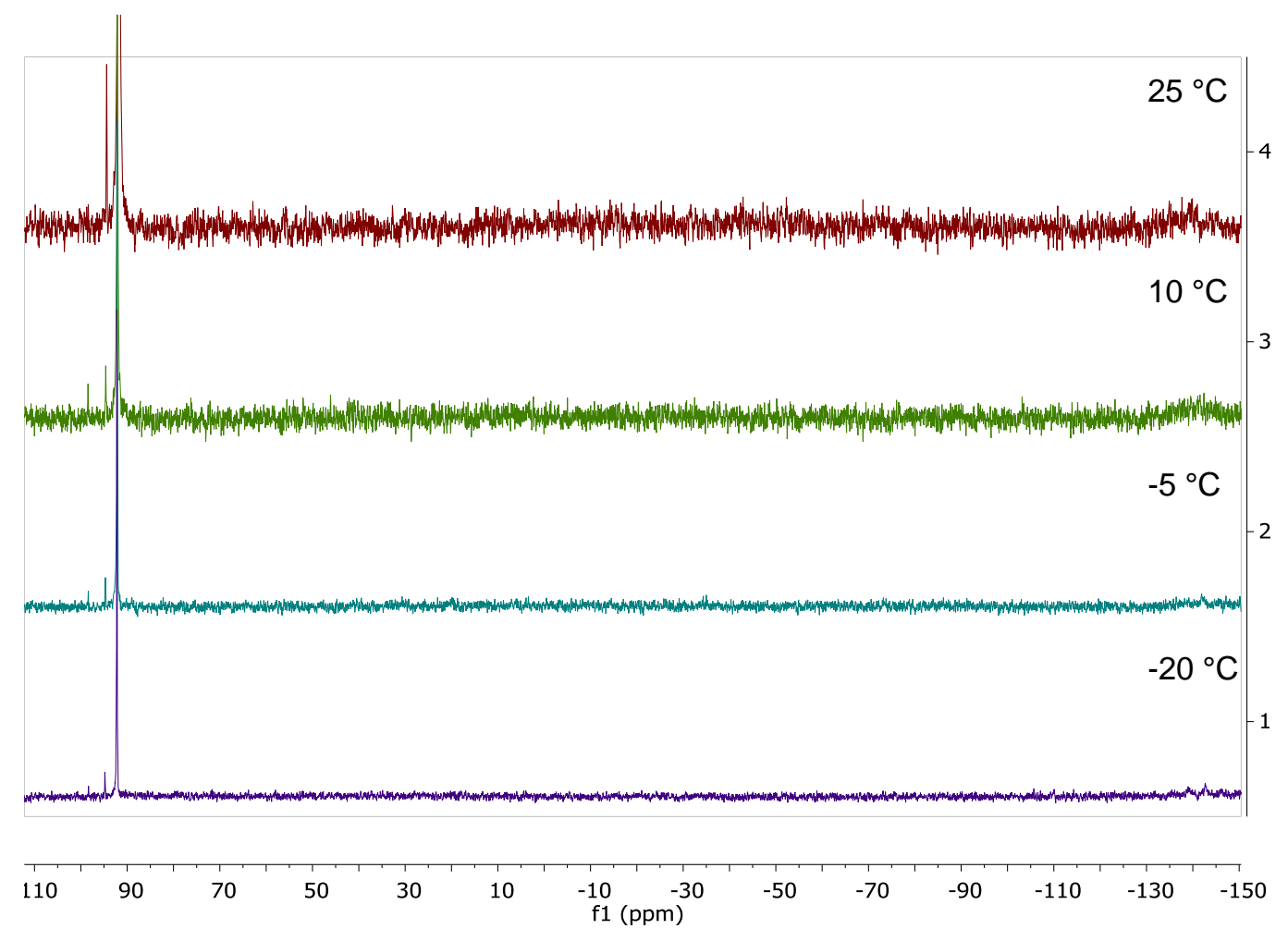

Figure S28. Variable-temperature ${ }^{31} \mathrm{P}\left\{{ }^{1} \mathrm{H}\right\}$ NMR spectra of $\left({ }^{i \mathrm{Pr}} \mathrm{PN}^{\mathrm{H}} \mathrm{P}\right) \mathrm{Fe}(\mathrm{H})(\mathrm{CO})\left(\mathrm{PF}_{6}\right)(6)$ in toluene$\mathrm{d}_{8}$. 


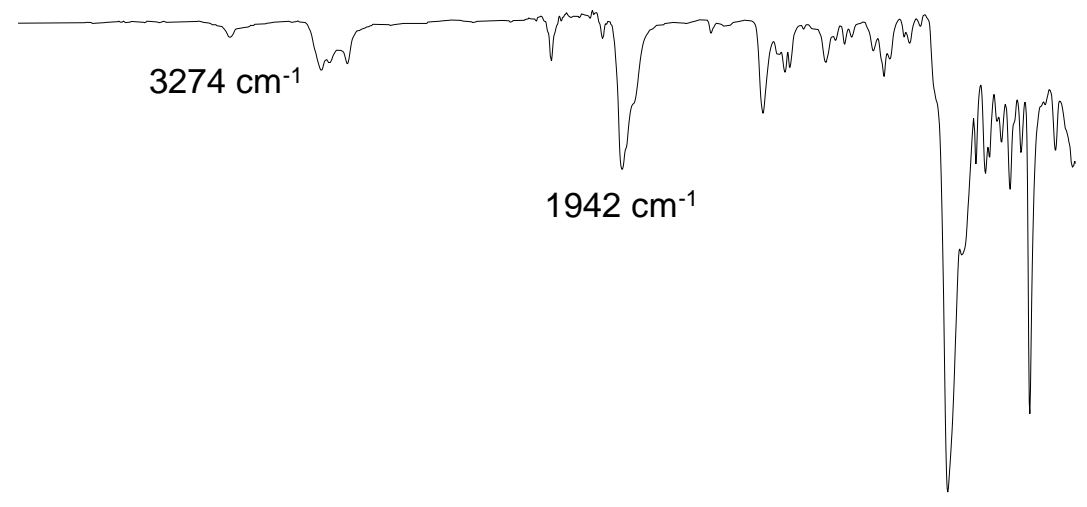

Figure S29. Solid-state IR spectrum of $\left({ }^{\mathrm{iPr}} \mathrm{PN}{ }^{\mathrm{H}} \mathrm{P}\right) \mathrm{Fe}(\mathrm{H})(\mathrm{CO})\left(\mathrm{PF}_{6}\right)(\boldsymbol{6})$ at room temperature: 3274 ( $\mathrm{UNH}_{\mathrm{NH}}$, 1942 (vco). 


\section{Compound 7}

NMR characterization data for $\mathbf{7}$ in THF- $\mathrm{d}_{8}$ are shown in Figures S30-S33.

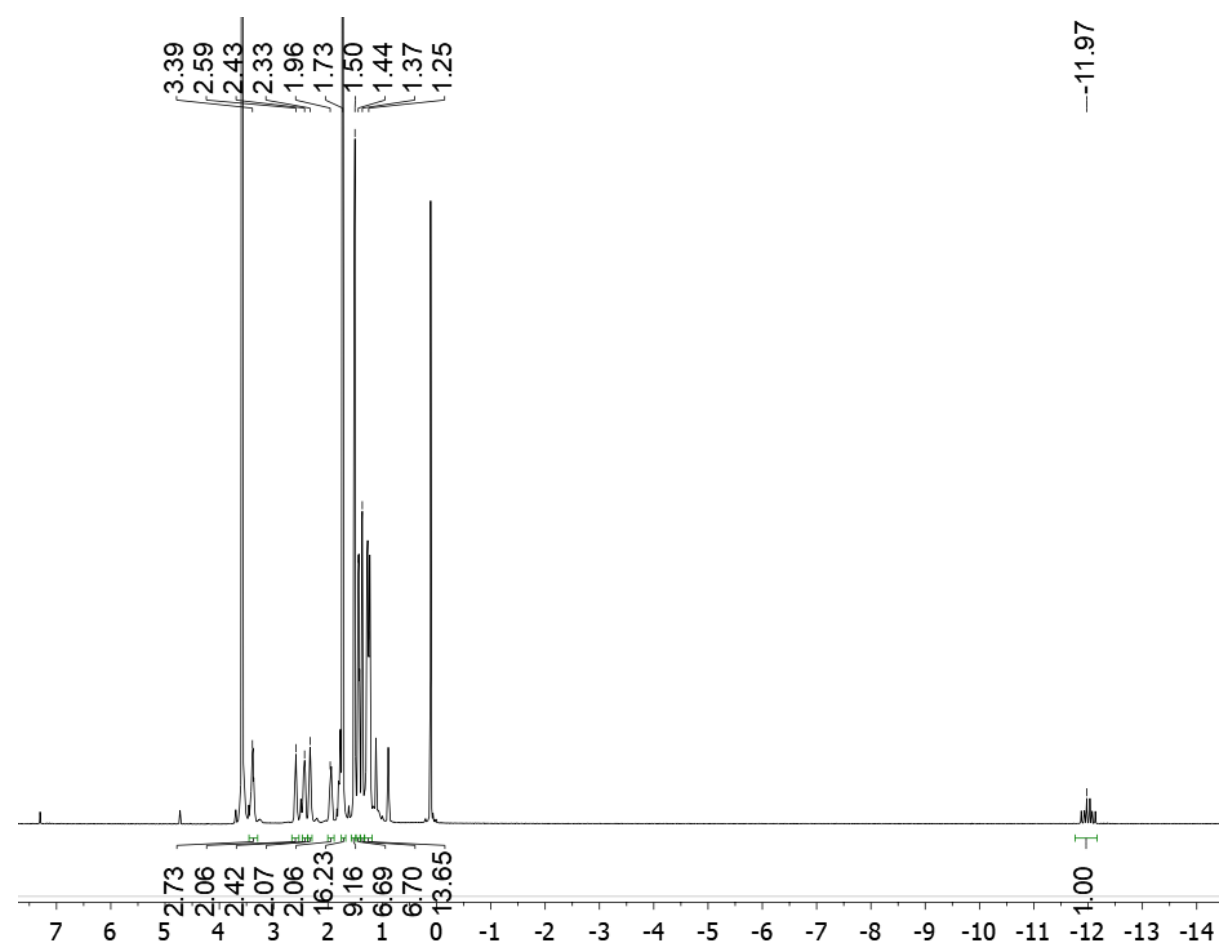

Figure S30. ${ }^{1} \mathrm{H}$ NMR spectrum of 7 in THF-d $\mathrm{d}_{8}$ at room temperature.

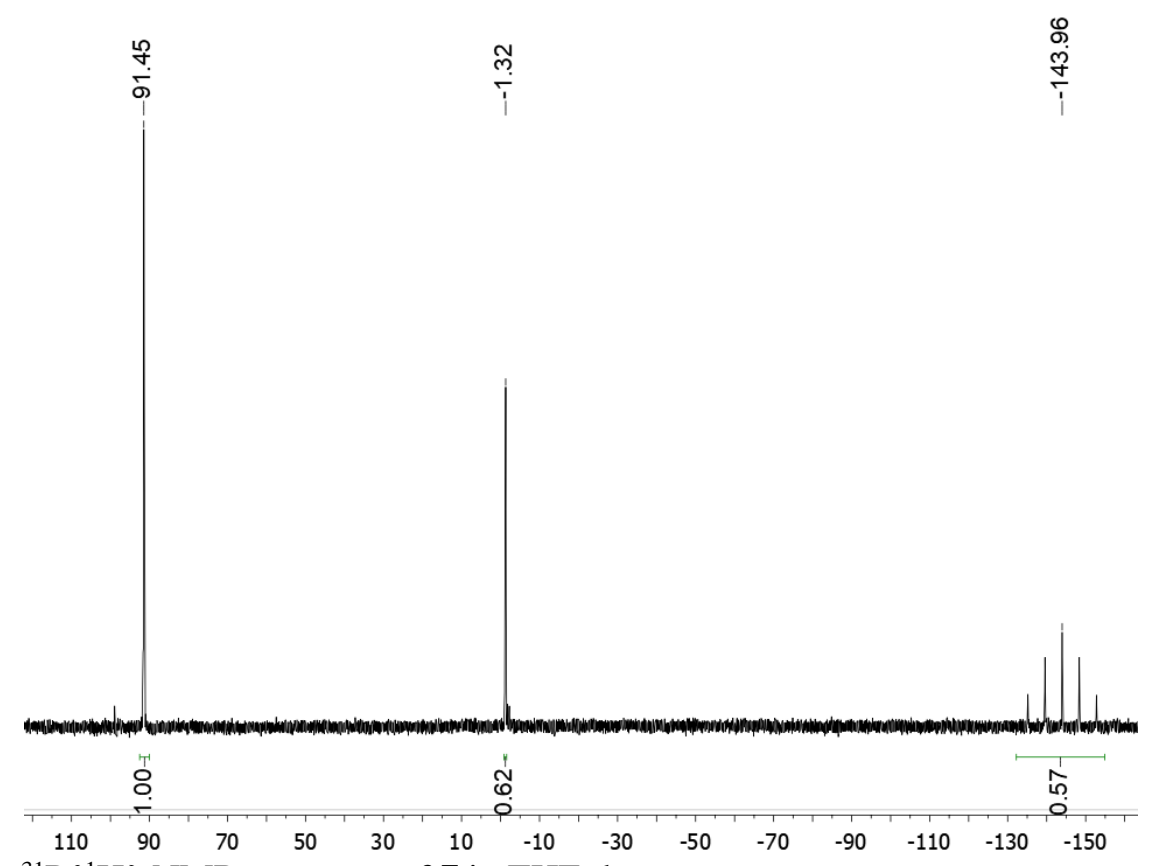

Figure $\mathrm{S} 31 .{ }^{31} \mathrm{P}\left\{{ }^{1} \mathrm{H}\right\}$ NMR spectrum of $\mathbf{7}$ in $\mathrm{THF}-\mathrm{d}_{8}$ at room temperature. 


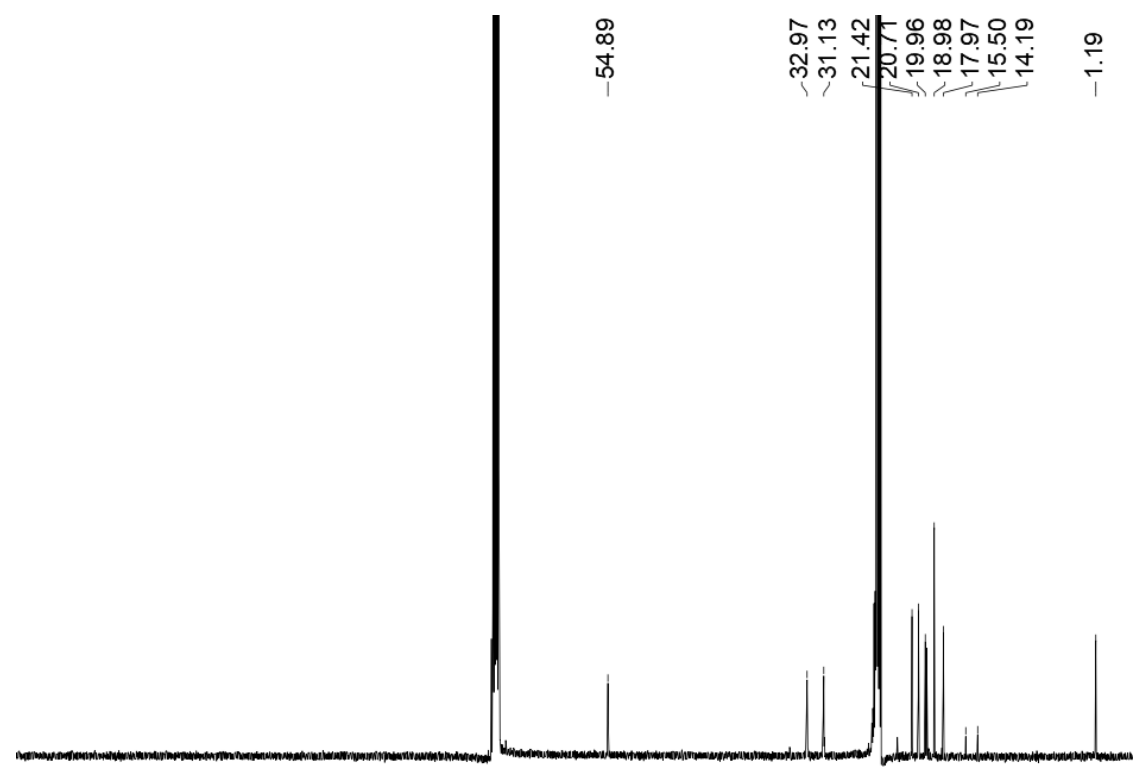

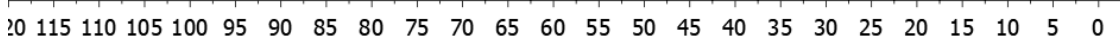

Figure S32. ${ }^{13} \mathrm{C}\left\{{ }^{1} \mathrm{H}\right\}$ NMR spectrum of 7 in $\mathrm{THF}_{8} \mathrm{~d}_{8}$ at room temperature.
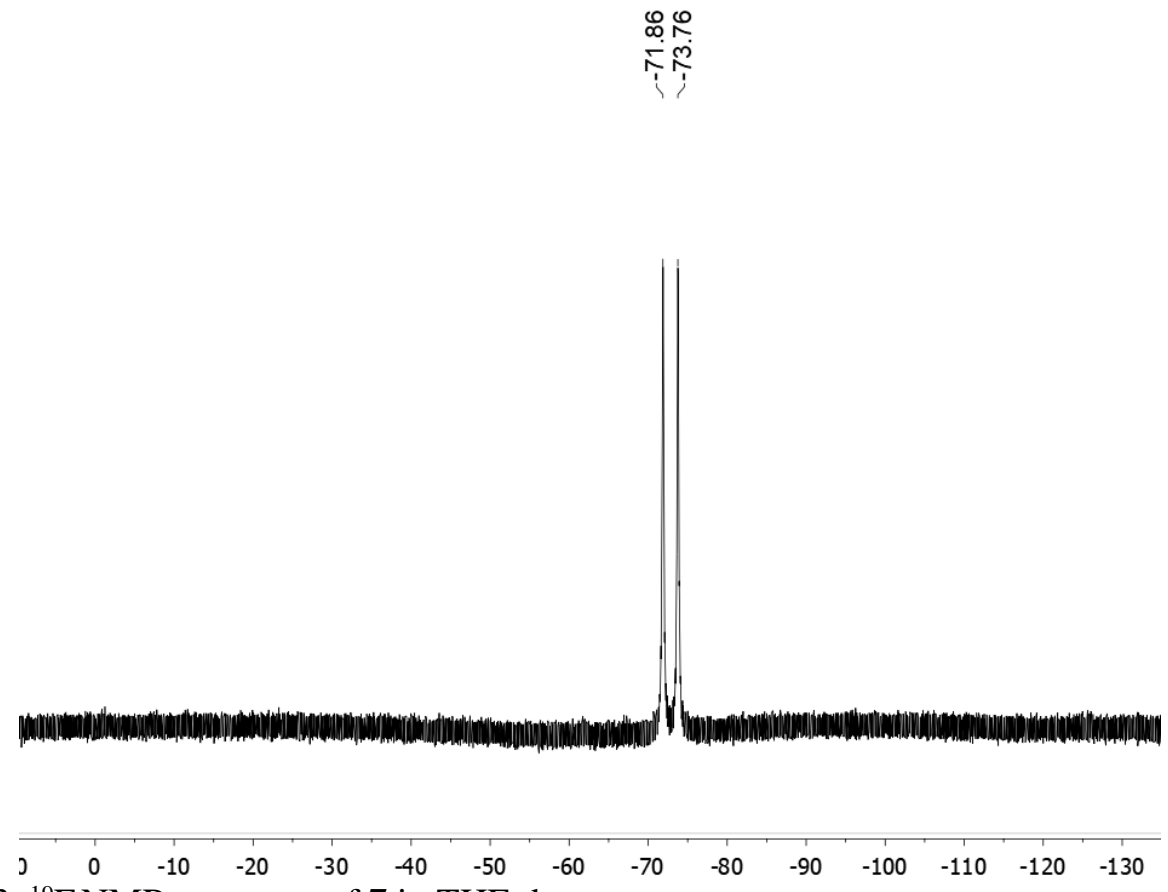

Figure $\mathrm{S} 33 .{ }^{19} \mathrm{~F}$ NMR spectrum of 7 in THF- $\mathrm{d}_{8}$ at room temperature. 


\section{Compound 8}

${ }^{1} \mathrm{H},{ }^{31} \mathrm{P}\left\{{ }^{1} \mathrm{H}\right\}$, and ${ }^{19} \mathrm{~F}$ NMR spectra in $\mathrm{d}_{8}$-THF of $\left[\left({ }^{\mathrm{iPr}} \mathrm{PN}^{\mathrm{H}} \mathrm{P}\right) \mathrm{Fe}(\mathrm{H})\left(\mathrm{H}_{2}\right)(\mathrm{CO})\right]\left[\mathrm{PF}_{6}\right](\mathbf{8})$, as well as the same complex with a $\mathrm{BAr}_{4}^{\mathrm{F}}$ counterion, are shown in Figures S34-S39. At room temperature in THF with 1 atm $\mathrm{H}_{2}, \mathbf{8}$ is the major species in equilibrium with 5-THF (roughly 2:1 ratio for both anions). Small amounts of $\mathbf{4}$ are present even in freshly synthesized solutions of $\mathbf{8}$.

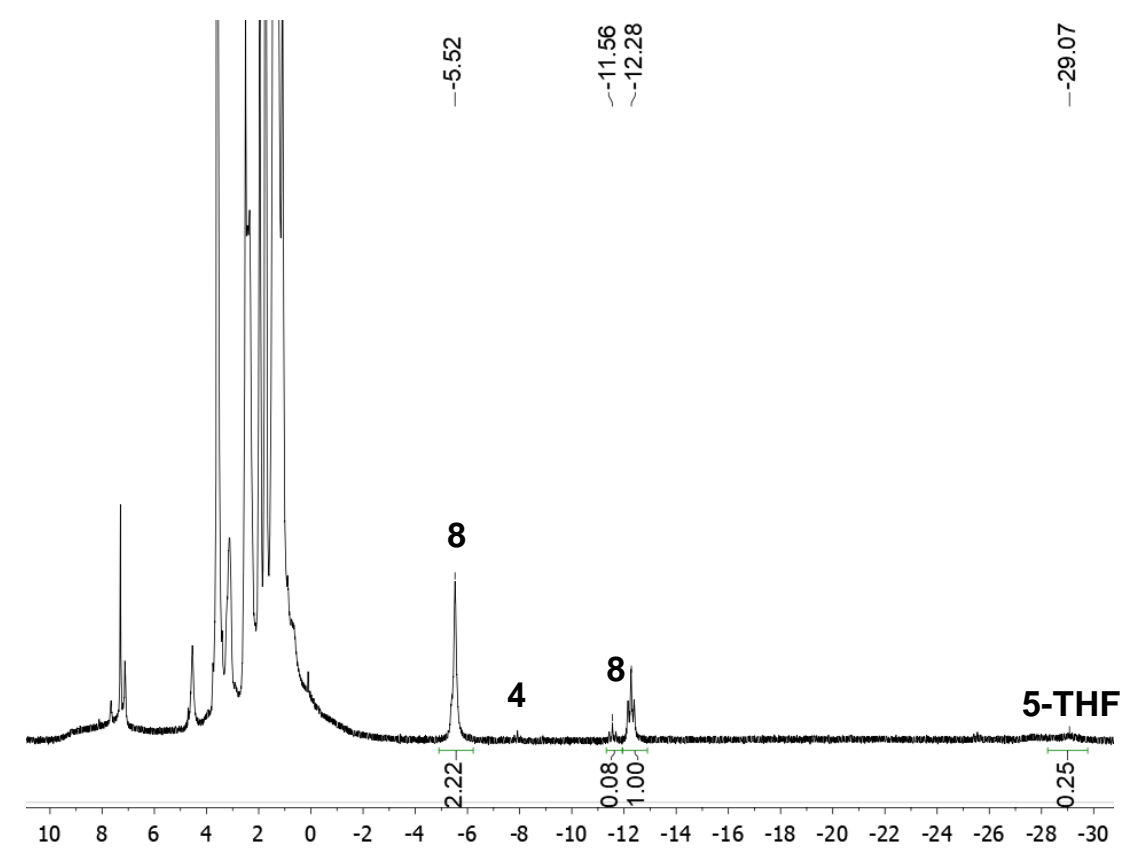

Figure S34. ${ }^{1} \mathrm{H}$ NMR spectrum of two isomers of $\left[\left({ }^{\mathrm{iPr} P N}{ }^{\mathrm{H}} \mathrm{P}\right) \mathrm{Fe}(\mathrm{H})\left(\mathrm{H}_{2}\right)(\mathrm{CO})\right]\left[\mathrm{PF}_{6}\right](\mathbf{8})$ and 5-THF with a small amount of $\mathbf{4}$ in $\mathrm{d}_{8}$-THF at room temperature. 


$$
\begin{aligned}
& \text { ํํㅇㅇㅛ } \\
& \text { ํํ잉 }
\end{aligned}
$$

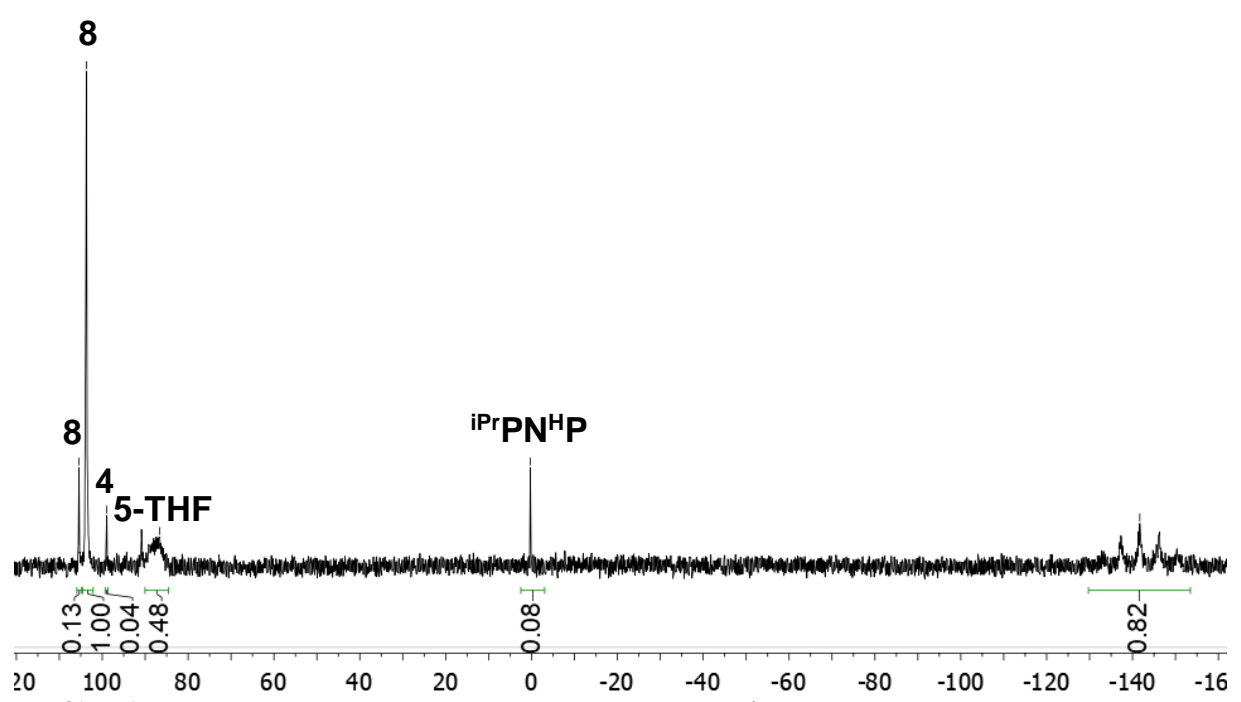

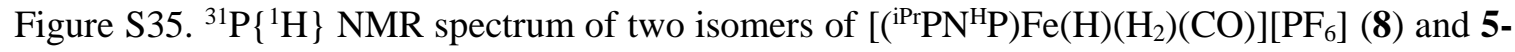
THF with a small amount of $\mathbf{4}$ and free ligand in $\mathrm{d}_{8}$-THF at room temperature.

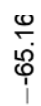

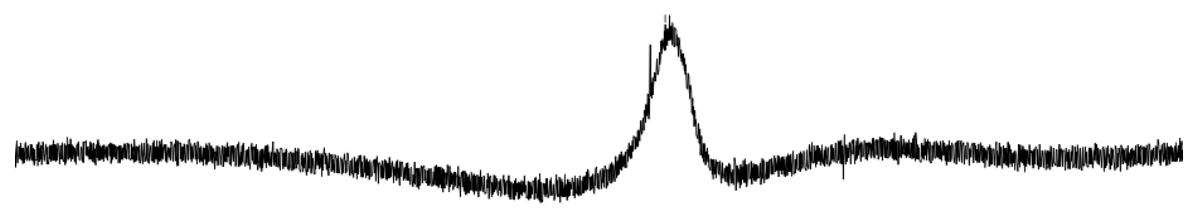

\begin{tabular}{llllllllllllll}
\hline 0 & -10 & -20 & -30 & -40 & -50 & -60 & -70 & -80 & -90 & -100 & -110 & -120
\end{tabular}

Figure S36. ${ }^{19} \mathrm{~F}$ NMR spectrum of two isomers of $\left[\left({ }^{\mathrm{iPr}} \mathrm{PN}{ }^{\mathrm{H}} \mathrm{P}\right) \mathrm{Fe}(\mathrm{H})\left(\mathrm{H}_{2}\right)(\mathrm{CO})\right]\left[\mathrm{PF}_{6}\right](\mathbf{8})$ and $\mathbf{5 - T H F}$ in $\mathrm{d}_{8}$-THF at room temperature. 


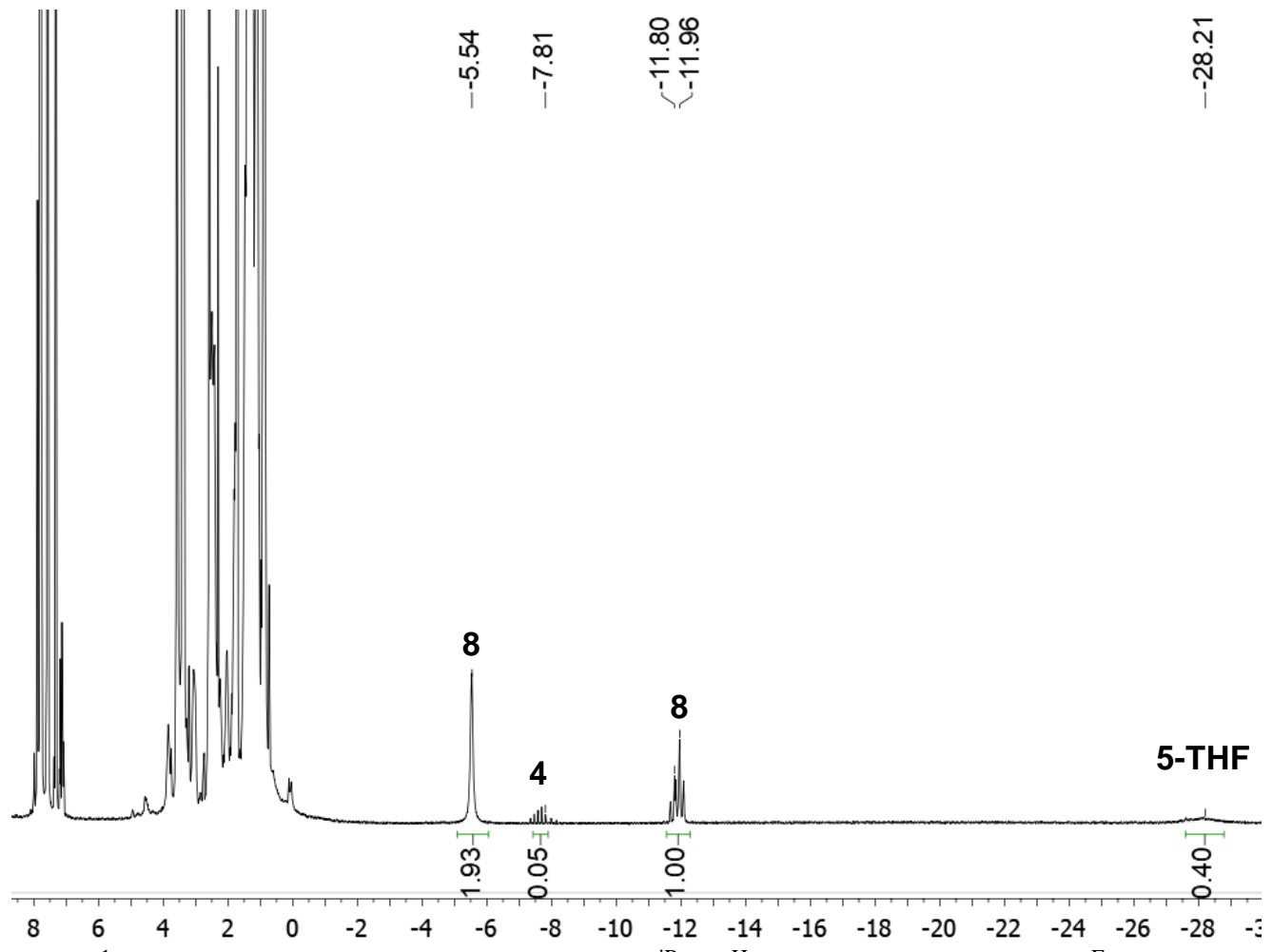

Figure S37. ${ }^{1} \mathrm{H}$ NMR spectrum of two isomers of $\left[\left({ }^{\left({ }^{P r}\right.} \mathrm{PN}{ }^{\mathrm{H}} \mathrm{P}\right) \mathrm{Fe}(\mathrm{H})\left(\mathrm{H}_{2}\right)(\mathrm{CO})\right]\left[\mathrm{BAr}{ }^{\mathrm{F}}{ }_{4}\right](\mathbf{8})$ and 5-THF in THF- $\mathrm{d}_{8}$ at room temperature. A small quantity of $\mathbf{4}$ is also observed. 


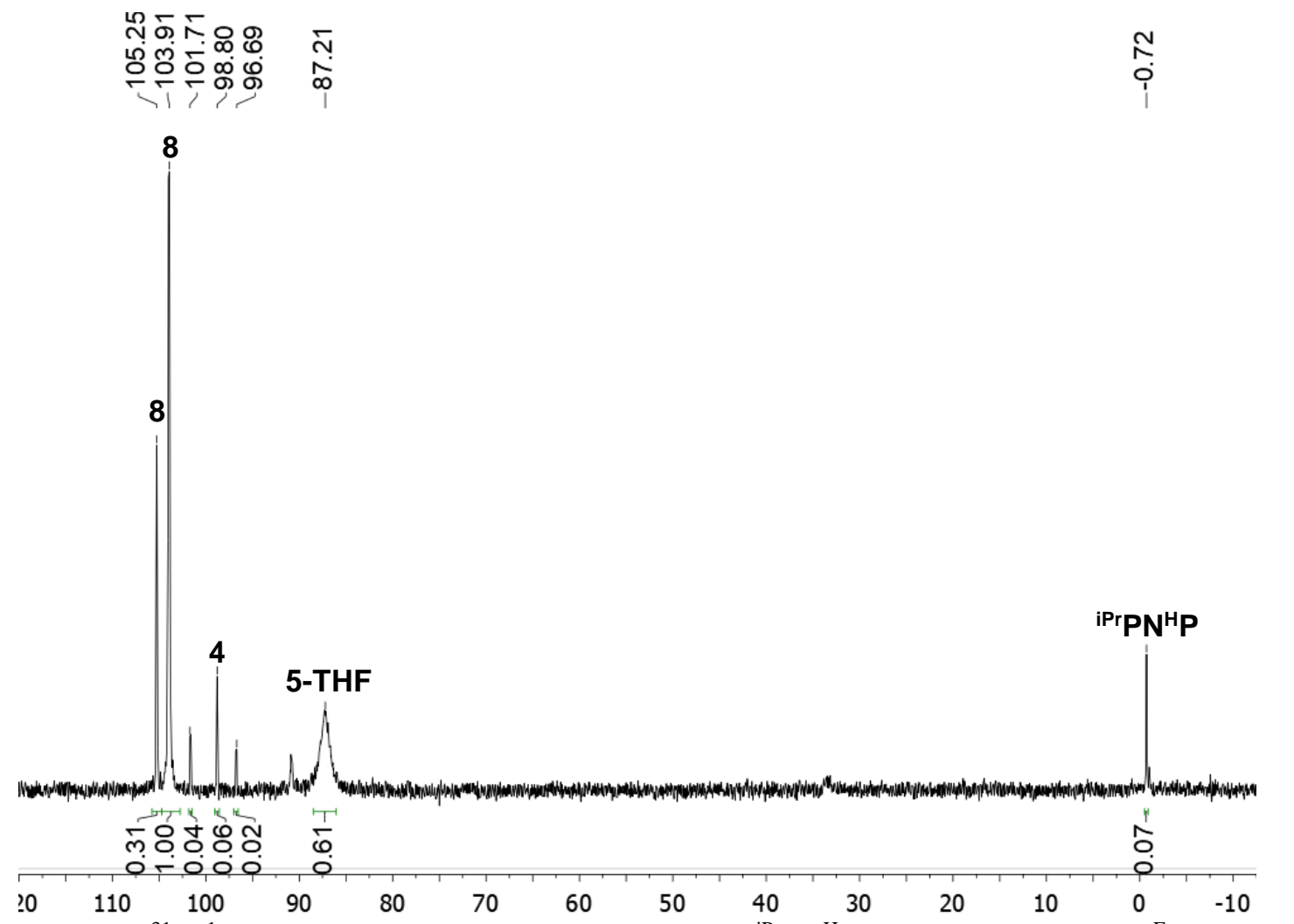

Figure S38. ${ }^{31} \mathrm{P}\left\{{ }^{1} \mathrm{H}\right\}$ NMR spectrum of two isomers of $\left[\left({ }^{\left({ }^{P r}\right.} \mathrm{PN}^{\mathrm{H}} \mathrm{P}\right) \mathrm{Fe}(\mathrm{H})\left(\mathrm{H}_{2}\right)(\mathrm{CO})\right]\left[\mathrm{BAr}^{\mathrm{F}}{ }_{4}\right](\mathbf{8})$ and 5-THF in THF- $\mathrm{d}_{8}$ at room temperature. Small quantities of $\mathbf{4}$ and free ligand are also observed.

ֻัণ

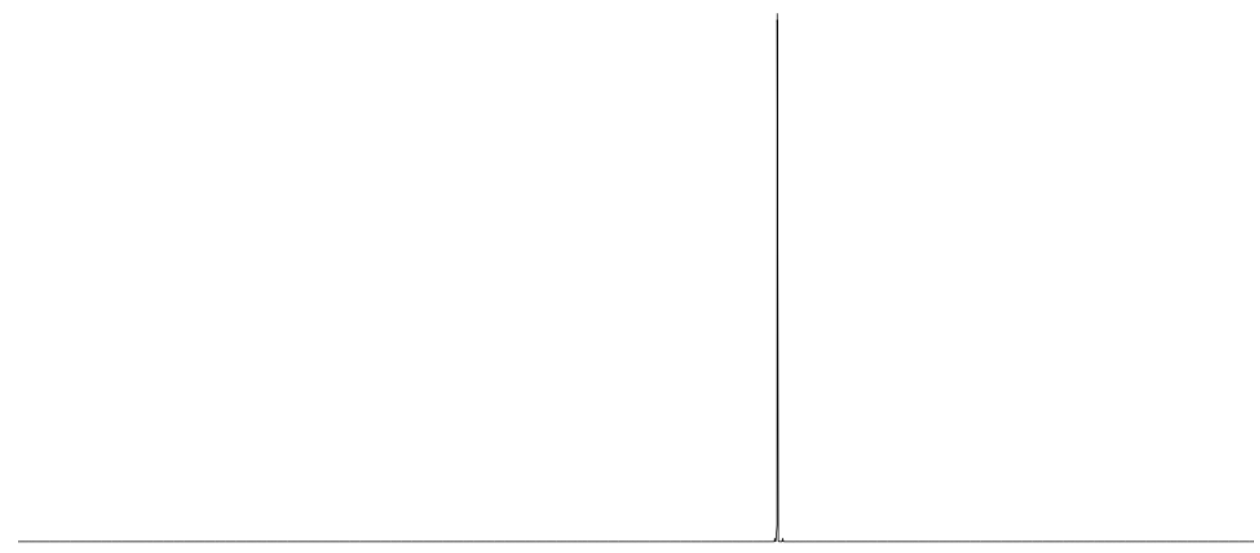

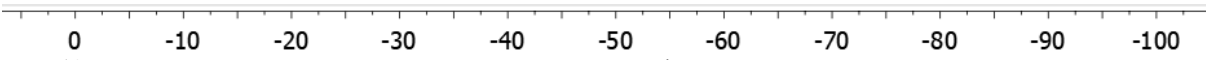

Figure S39. ${ }^{19} \mathrm{~F}$ NMR spectrum of two isomers of $\left[\left({ }^{\mathrm{iPr}}{ }^{\mathrm{PN}}{ }^{\mathrm{H}} \mathrm{P}\right) \mathrm{Fe}(\mathrm{H})\left(\mathrm{H}_{2}\right)(\mathrm{CO})\right]\left[\mathrm{BAr}{ }^{\mathrm{F}}\right](\mathbf{8})$ in $\mathrm{THF}$ at room temperature. 


\section{Compound 11}

NMR and IR data for the CN bridging dimer complex 11 is shown in Figures S40-S44.

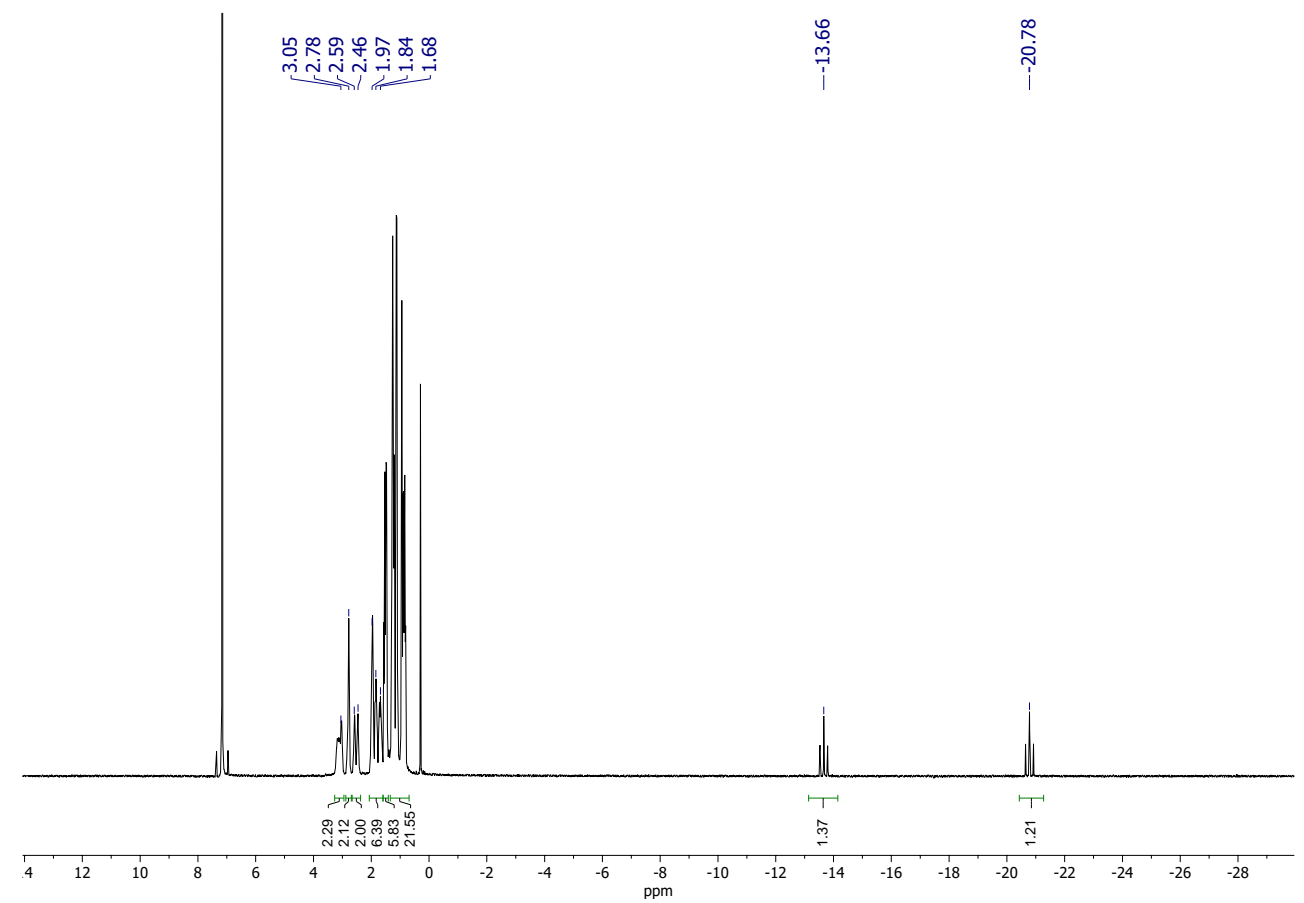

Figure S40. ${ }^{1} \mathrm{H}$ NMR of $\left[\left\{\left({ }^{\left({ }^{P r}\right.} \mathrm{PN}^{\mathrm{H}} \mathrm{P}\right) \mathrm{Fe}(\mathrm{H})(\mathrm{CO})\right\}_{2}\{\mu-\mathrm{CN}\}\right]\left[\mathrm{PF}_{6}\right](\mathbf{1 1})$ in $\mathrm{C}_{6} \mathrm{D}_{6}$.

$$
\text { mֻ }
$$

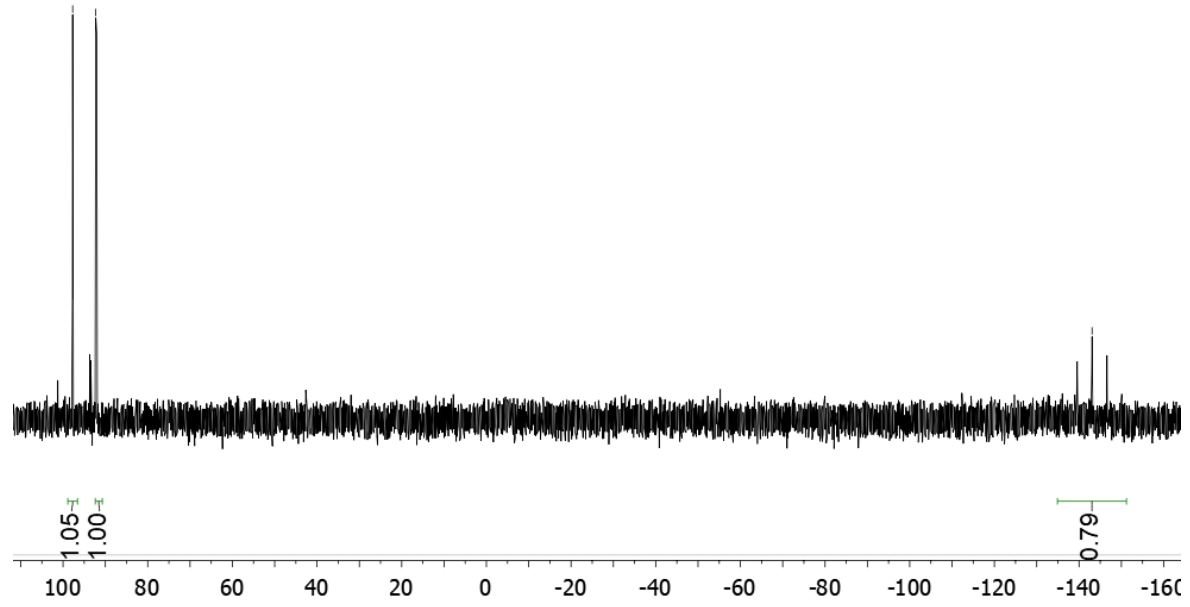

Figure $\mathrm{S} 41 .{ }^{31} \mathrm{P}\left\{{ }^{1} \mathrm{H}\right\} \mathrm{NMR}$ of $\left[\left\{\left({ }^{\left({ }^{\mathrm{Pr}} \mathrm{PN}\right.}{ }^{\mathrm{H}} \mathrm{P}\right) \mathrm{Fe}(\mathrm{H})(\mathrm{CO})\right\}_{2}\{\mu-\mathrm{CN}\}\right]\left[\mathrm{PF}_{6}\right](\mathbf{1 1})$ in $\mathrm{C}_{6} \mathrm{D}_{6}$. 


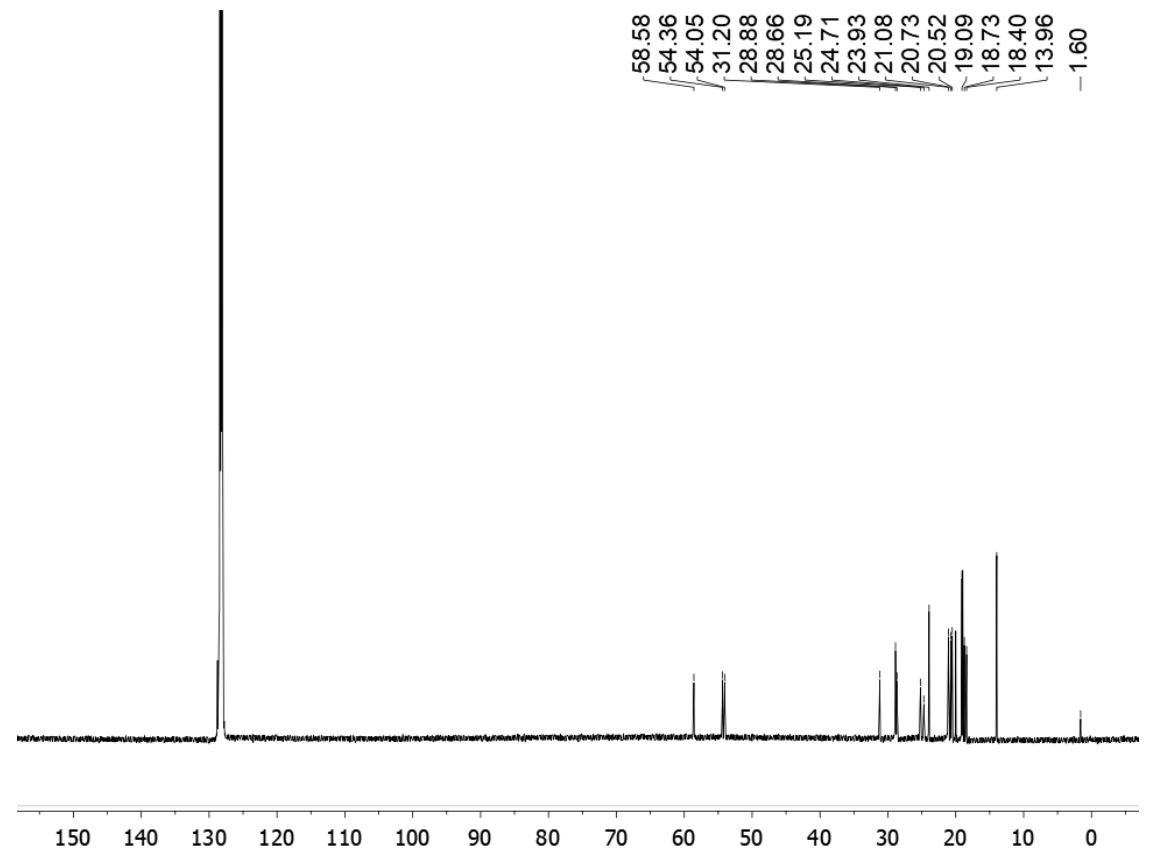

Figure S42. ${ }^{13} \mathrm{C}\left\{{ }^{1} \mathrm{H}\right\}$ NMR of $\left[\left\{\left({ }^{\mathrm{iPr}} \mathrm{PN}{ }^{\mathrm{H}} \mathrm{P}\right) \mathrm{Fe}(\mathrm{H})(\mathrm{CO})\right\}_{2}\{\mu-\mathrm{CN}\}\right]\left[\mathrm{PF}_{6}\right](\mathbf{1 1})$ in $\mathrm{C}_{6} \mathrm{D}_{6}$.

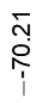

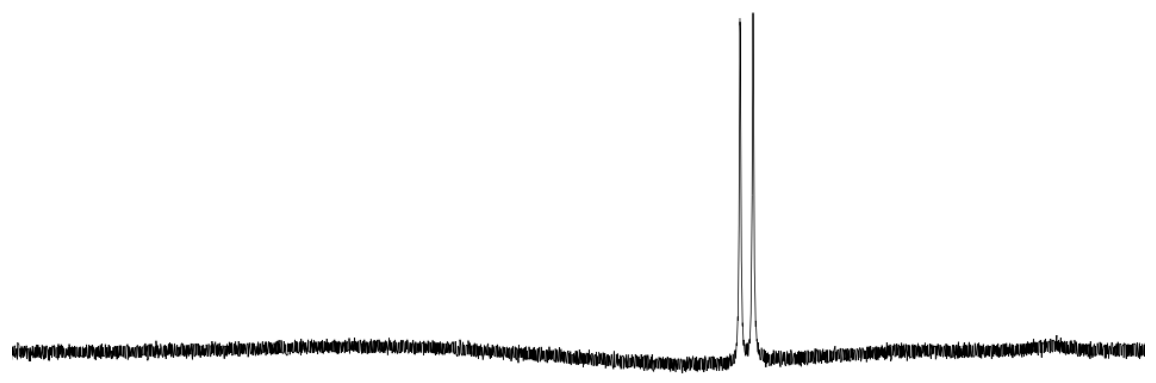

$\begin{array}{lllllllllllll}10 & 0 & -10 & -20 & -30 & -40 & -50 & -60 & -70 & -80 & -90 & -100 & -110\end{array}$

Figure S43. ${ }^{19} \mathrm{~F}$ NMR of $\left[\left\{\left({ }^{\left({ }^{P}\right.}{ }^{2} N^{H} \mathrm{P}\right) \mathrm{Fe}(\mathrm{H})(\mathrm{CO})\right\}_{2}\{\mu-\mathrm{CN}\}\right]\left[\mathrm{PF}_{6}\right](\mathbf{1 1})$ in $\mathrm{C}_{6} \mathrm{D}_{6}$. 


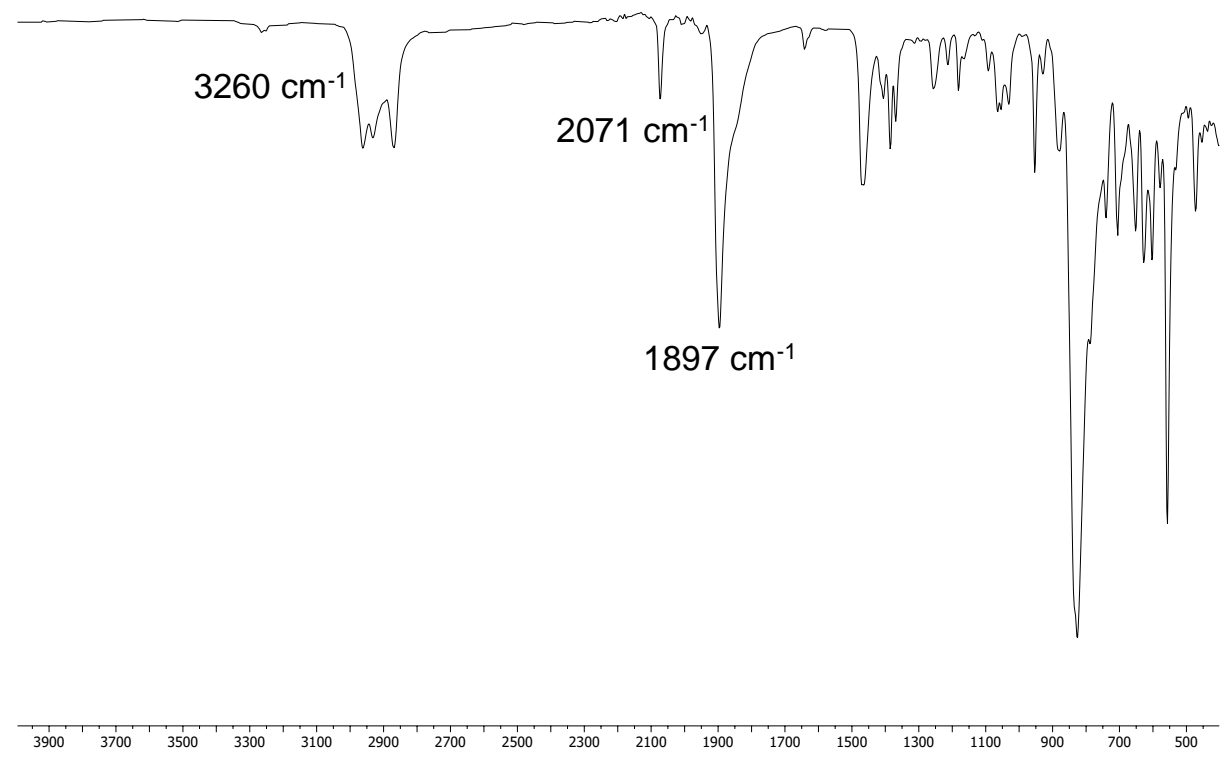

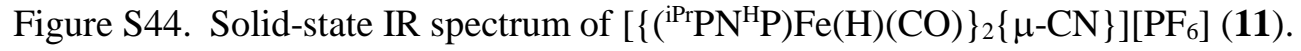




\section{Compound 12}

NMR and solution state IR data for the formate bridging dimer $\mathbf{1 2}$ are shown in Figures S45-S48.

This complex decomposes rapidly under a dinitrogen atmosphere, but is far more stable under an atmosphere of $\mathrm{CO}_{2}$, indicating decarboxylation is involved in the decomposition mechanism.

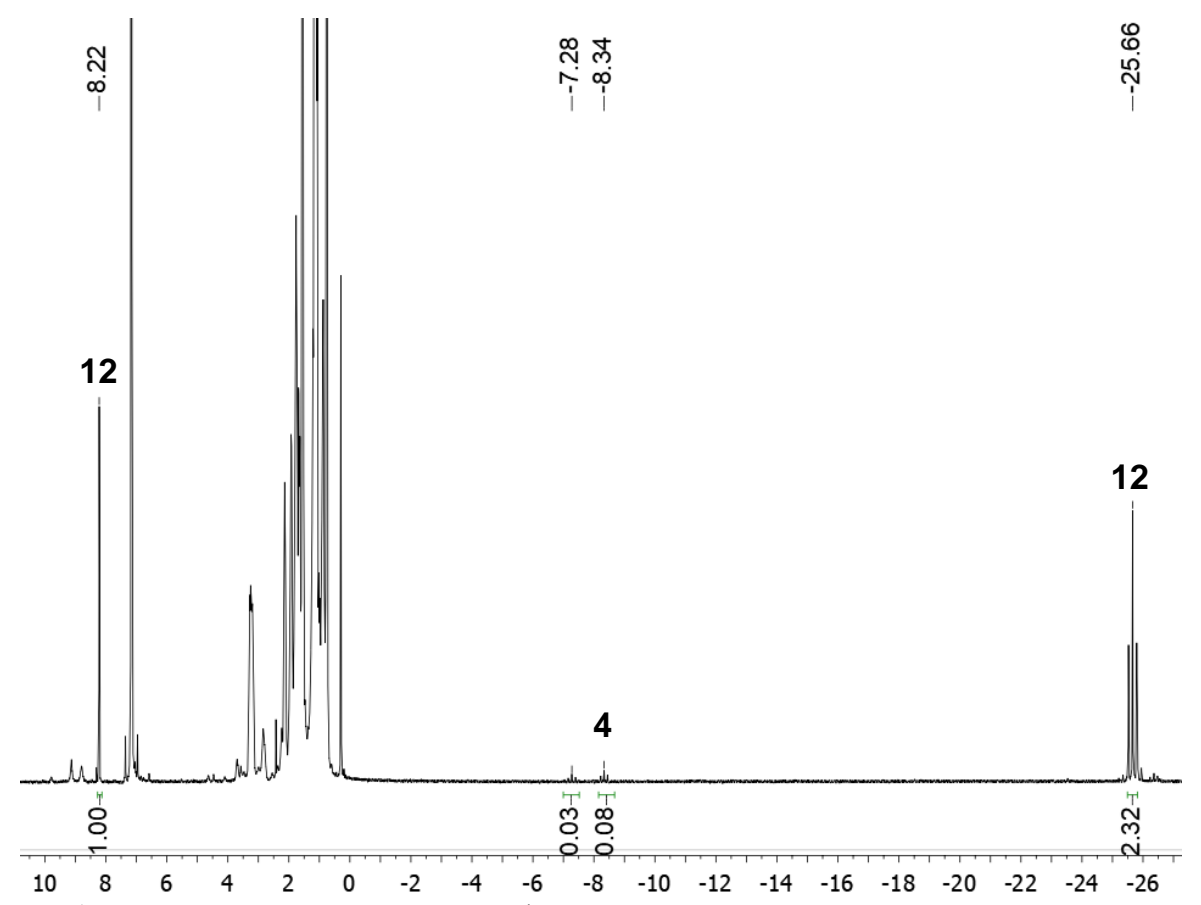

Figure S45. ${ }^{1} \mathrm{H}$ NMR spectrum of $\left[\left\{\left({ }^{\left({ }^{\mathrm{PP}}{ }^{2} \mathrm{PN}\right.}{ }^{\mathrm{H}} \mathrm{P}\right) \mathrm{Fe}(\mathrm{H})(\mathrm{CO})\right\}_{2}\{\mu-(\mathrm{O}) \mathrm{C}(\mathrm{O}) \mathrm{H}\}\right]\left[\mathrm{PF}_{6}\right] \quad(\mathbf{1 2})$ and decomposition products. The hydride peak at $-8.34 \mathrm{ppm}$ corresponds to $\mathbf{4}$. A small excess of $\mathbf{1 0}$ is present which causes the hydride of $\mathbf{1 2}$ to over integrate because the hydride peaks are overlapping. 


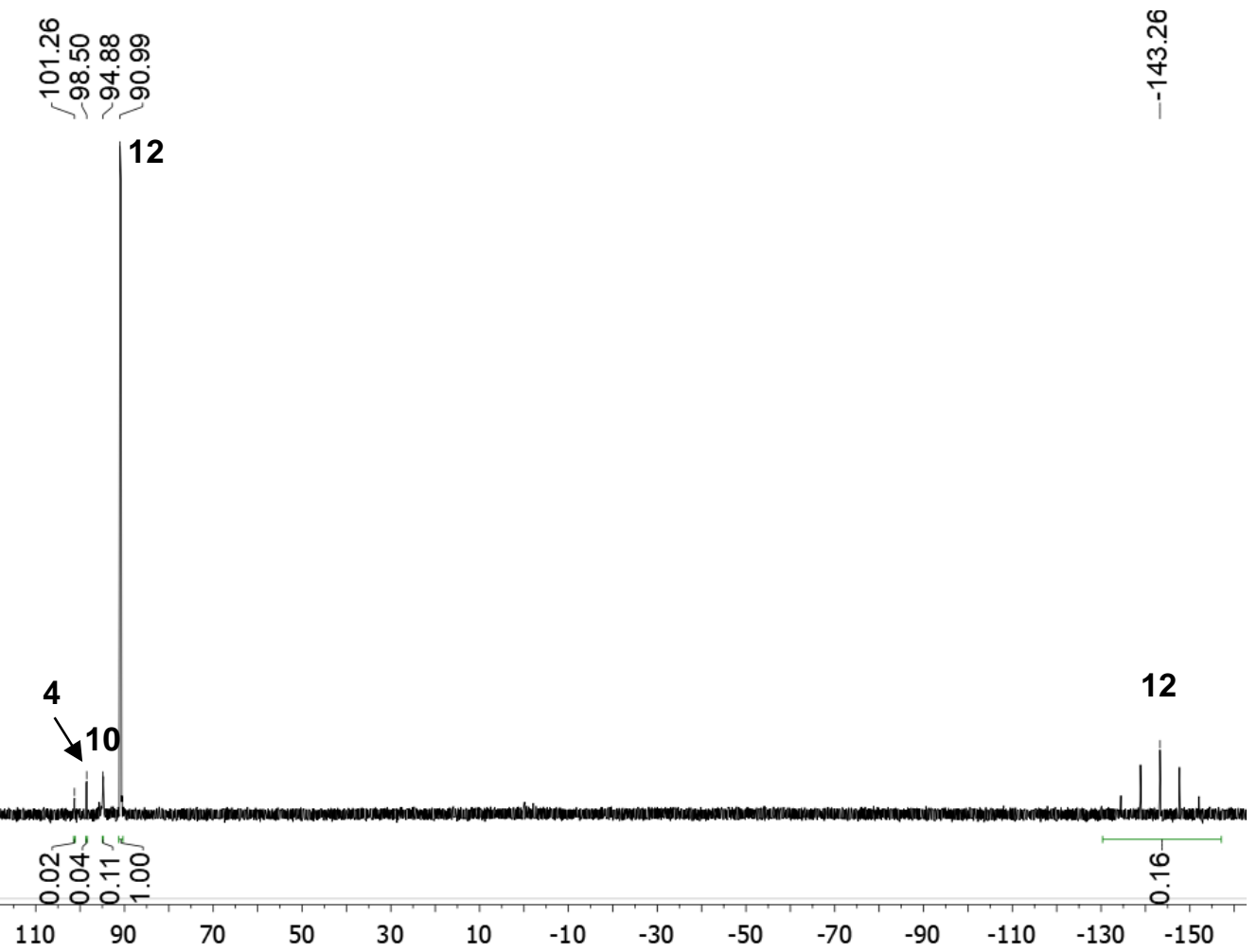

Figure S46. ${ }^{31} \mathrm{P}\left\{{ }^{1} \mathrm{H}\right\}$ NMR spectrum of $\left[\left\{\left({ }^{\mathrm{iPr} P N}{ }^{\mathrm{H} P}\right) \mathrm{Fe}(\mathrm{H})(\mathrm{CO})\right\}_{2}\{\mu-(\mathrm{O}) \mathrm{C}(\mathrm{O}) \mathrm{H}\}\right]\left[\mathrm{PF}_{6}\right](\mathbf{1 2})$ and decomposition products. The peak at $98.5 \mathrm{ppm}$ corresponds to $\mathbf{4}$. A small excess of $\mathbf{1 0}$ is present. 


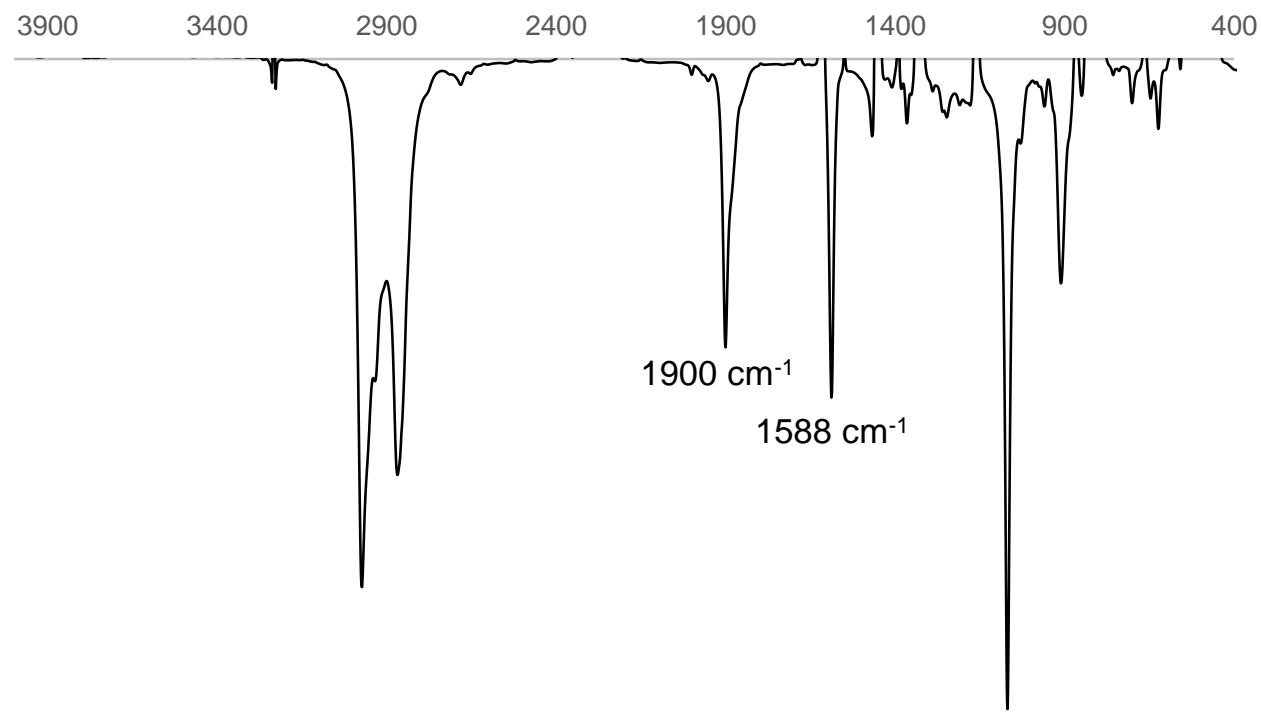

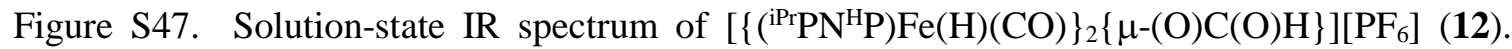
Background spectrum taken of $\mathrm{C}_{6} \mathrm{D}_{6}$ solvent and subtracted from sample spectrum. $v_{\mathrm{CO}}$, carbonyl $=1900 \mathrm{~cm}^{-1}, v_{\mathrm{CO}}$, formate $=1588 \mathrm{~cm}^{-1}$.

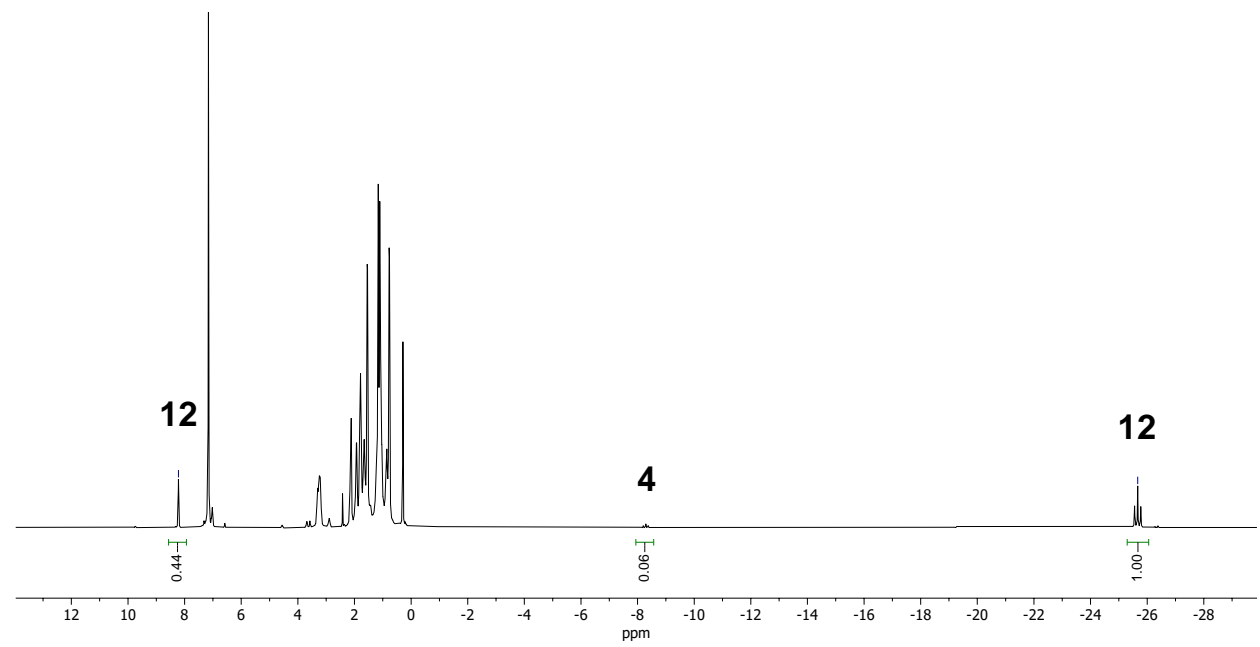

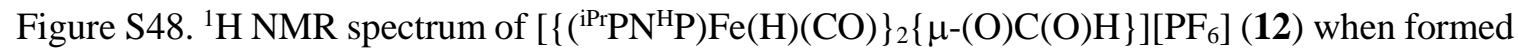
under 1 atm of $\mathrm{CO}_{2}$ after 96 hours, showing dramatically less formation of $\mathbf{4}$ and other decomposition species. 


\section{$\left[\left({ }^{\mathrm{iPr}} \mathrm{PN}^{\mathrm{H}} \mathrm{P}\right) \mathrm{Fe}(\mathrm{H})(\mathrm{CO})\left(\mathrm{PEt}_{3}\right)\right]\left[\mathrm{PF}_{6}\right]$}

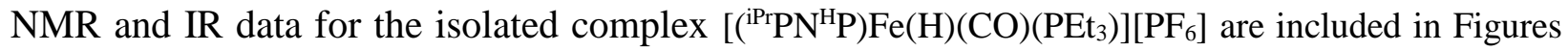

S49-S53 below.

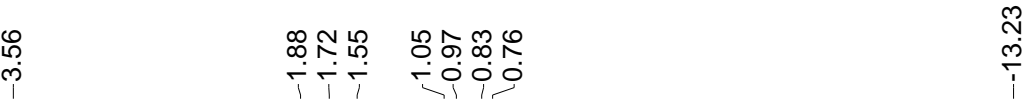

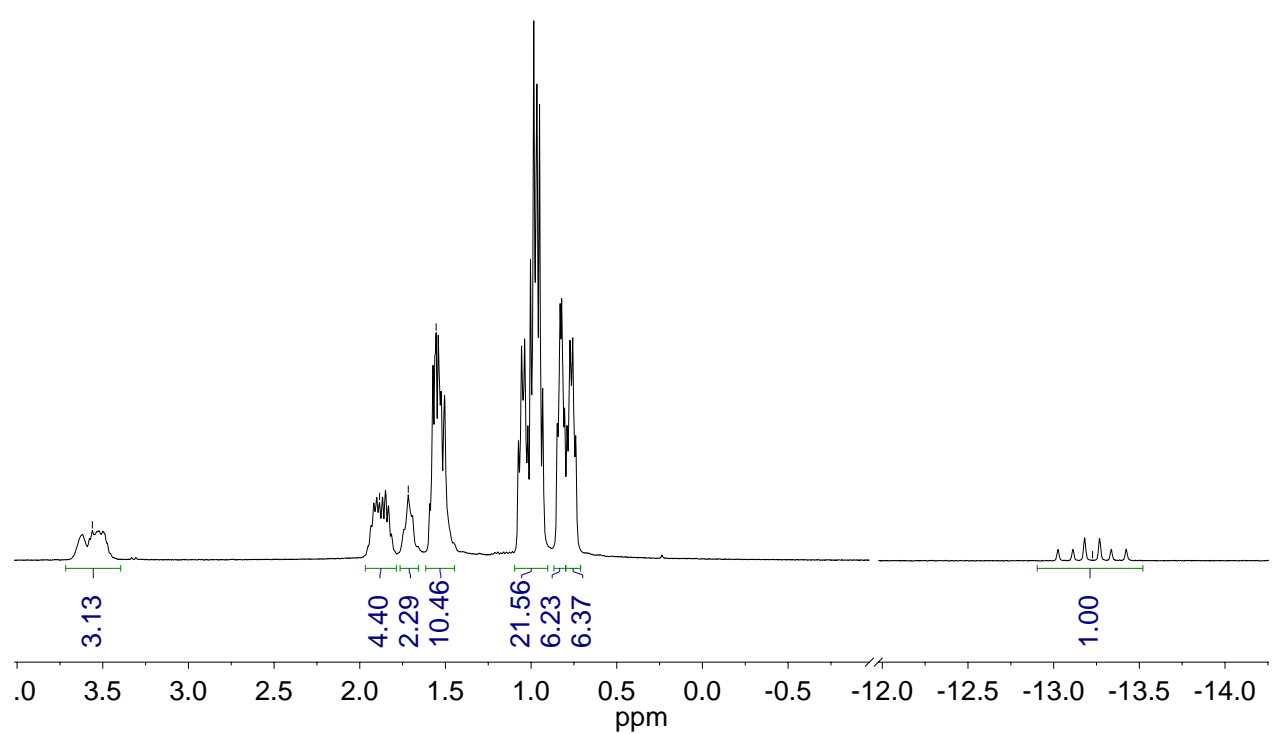

Figure S49. ${ }^{1} \mathrm{H}$ NMR of $\left[\left({ }^{\mathrm{iPr}} \mathrm{PN}{ }^{\mathrm{H}} \mathrm{P}\right) \mathrm{Fe}(\mathrm{H})(\mathrm{CO})\left(\mathrm{PEt}_{3}\right)\right]\left[\mathrm{PF}_{6}\right]$ in $\mathrm{C}_{6} \mathrm{D}_{6}$. 


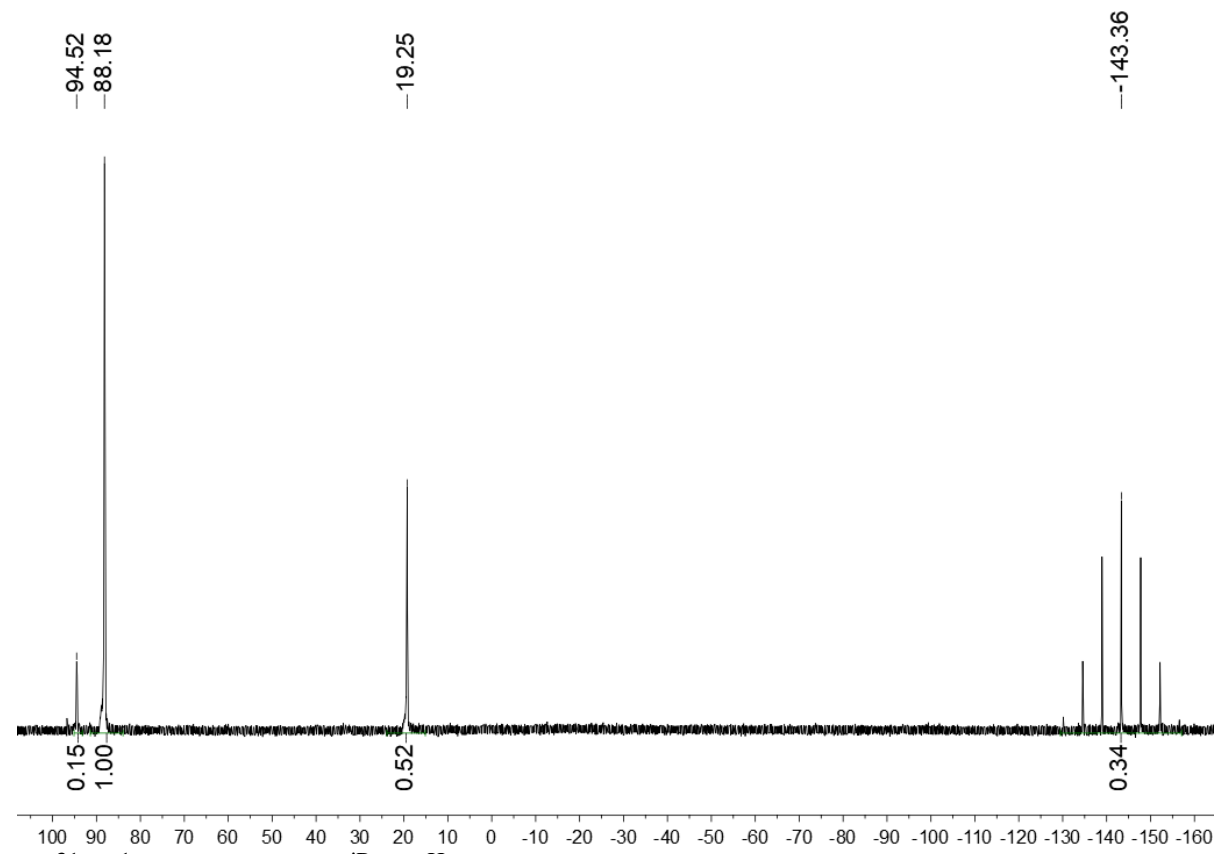

Figure S50. ${ }^{31} \mathrm{P}\left\{{ }^{1} \mathrm{H}\right\}$ NMR of $\left[\left({ }^{i} \mathrm{Pr} \mathrm{PN}^{\mathrm{H}} \mathrm{P}\right) \mathrm{Fe}(\mathrm{H})(\mathrm{CO})\left(\mathrm{PEt}_{3}\right)\right]\left[\mathrm{PF}_{6}\right]$ in $\mathrm{C}_{6} \mathrm{D}_{6}$. A small impurity is present at $94.5 \mathrm{ppm}$.

şֻ

ำi
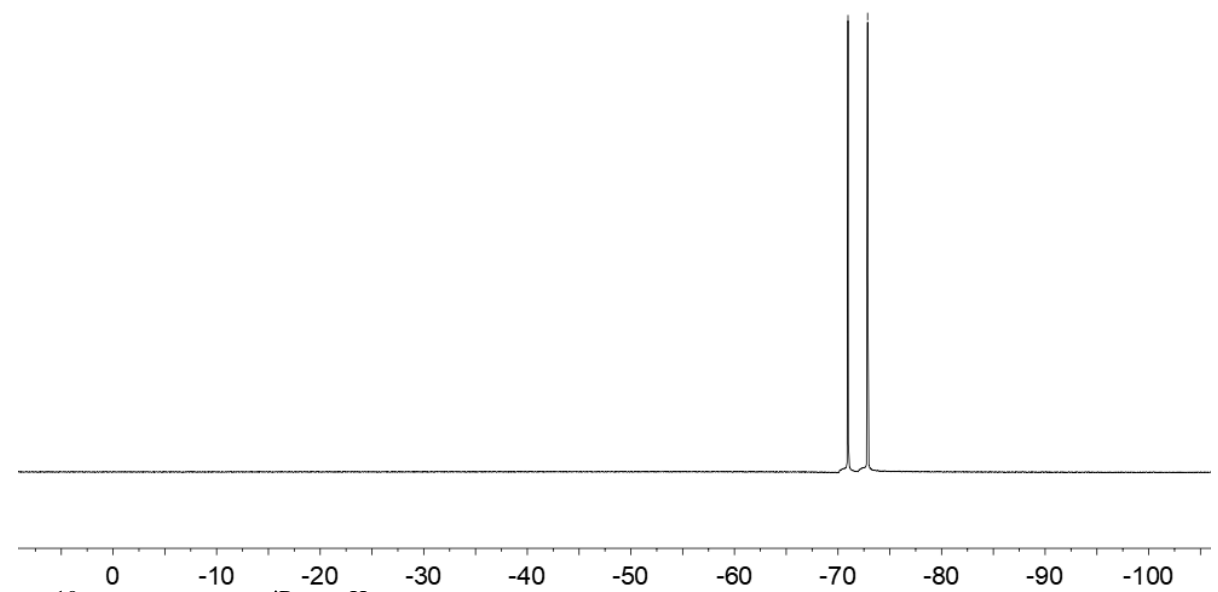

Figure S51. ${ }^{19} \mathrm{~F}$ NMR of $\left[\left({ }^{\mathrm{iPr} P N}{ }^{\mathrm{H}} \mathrm{P}\right) \mathrm{Fe}(\mathrm{H})(\mathrm{CO})\left(\mathrm{PEt}_{3}\right)\right]\left[\mathrm{PF}_{6}\right]$ in $\mathrm{C}_{6} \mathrm{D}_{6}$. 


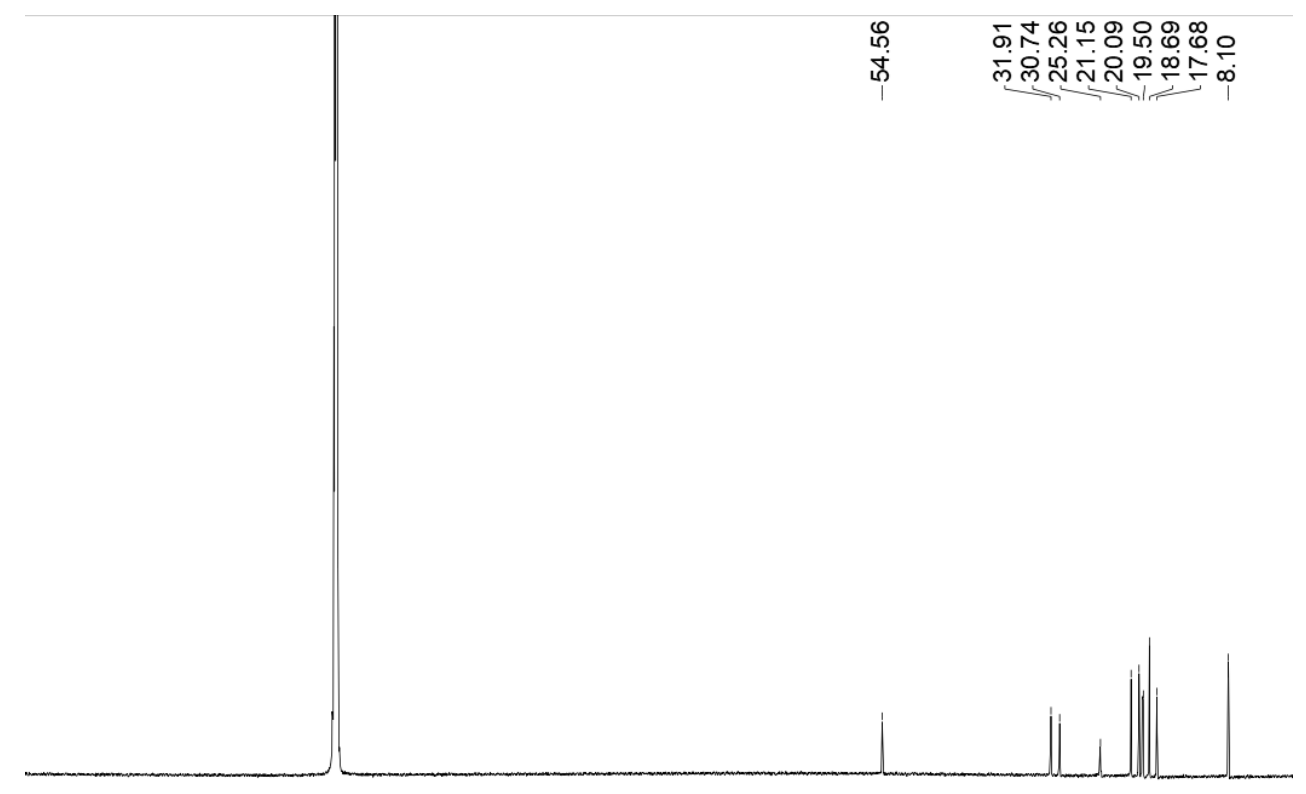

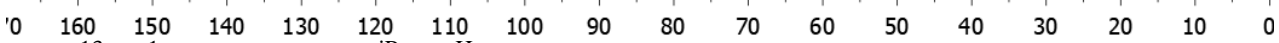
Figure S52. ${ }^{13} \mathrm{C}\left\{{ }^{1} \mathrm{H}\right\}$ NMR of $\left[\left({ }^{\mathrm{iPr}} \mathrm{PN}{ }^{\mathrm{H}} \mathrm{P}\right) \mathrm{Fe}(\mathrm{H})(\mathrm{CO})\left(\mathrm{PEt}_{3}\right)\right]\left[\mathrm{PF}_{6}\right]$ in $\mathrm{C}_{6} \mathrm{D}_{6}$.

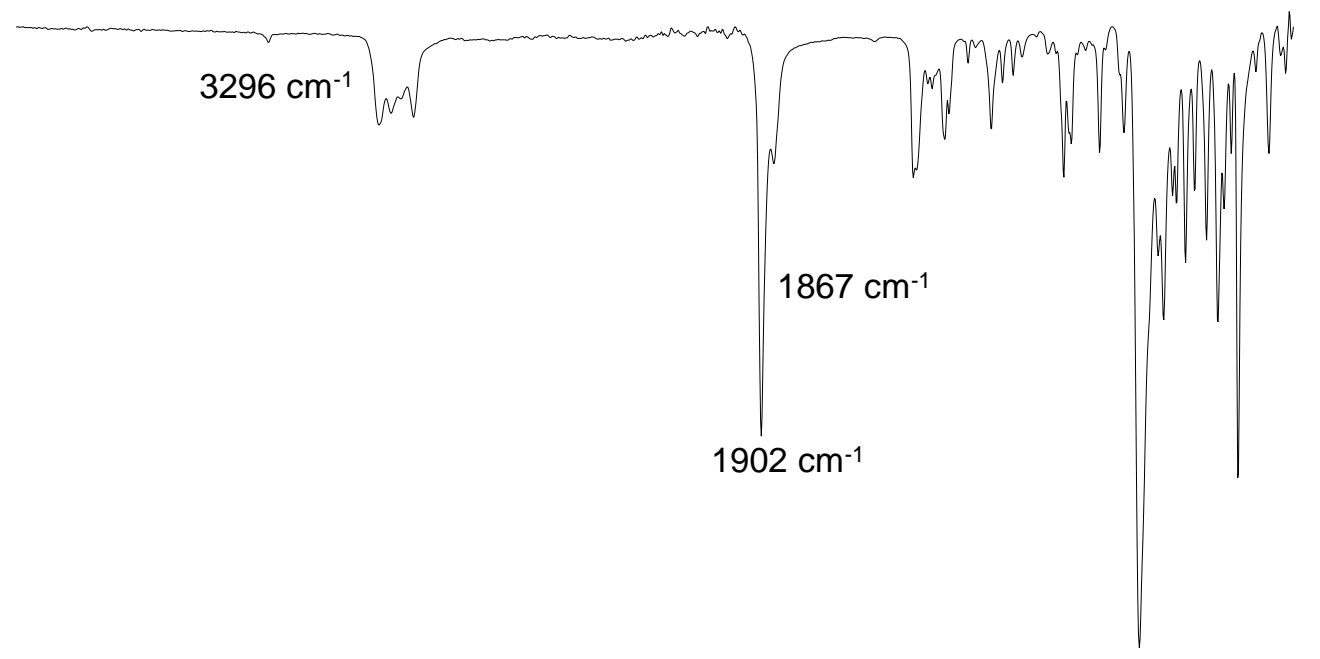

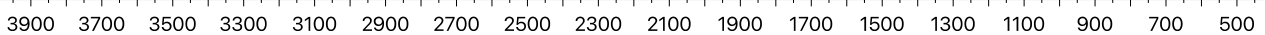

Figure S53. Solid-state IR spectrum of $\left[\left({ }^{\mathrm{iPr}} \mathrm{PN}^{\mathrm{H}} \mathrm{P}\right) \mathrm{Fe}(\mathrm{H})(\mathrm{CO})\left(\mathrm{PEt}_{3}\right)\right]\left[\mathrm{PF}_{6}\right]$. 
XI. Van't Hoff Plot for the Addition of $\mathrm{H}_{2}$ to $\mathbf{1}$ :

In a glovebox, a solution of 1 (6 mg, 0.02 mmols) was made in THF- $d_{8}(450 \mu \mathrm{L})$. To this was added naphthalene (10 mg) as an internal standard. The solution was subsequently transferred into a J Young NMR tube, sealed, and removed from the glovebox. Using a Schlenk manifold filled with $\mathrm{H}_{2}$, the solution was subjected to three freeze-pump-thaw cycles and the headspace of the NMR tube filled with $\mathrm{H}_{2}$. The tube was resealed and removed from the Schlenk manifold. The solution was shaken vigorously and allowed to settle for 10 minutes. After insertion into the NMR probe, the temperature was regulated and the sample allowed to equilibrate for 10 minutes in between spectra. ${ }^{1} \mathrm{H}$ NMR spectra were taken with 16 scans, a delay time of $10 \mathrm{~s}$, and an acquisition time of 3.000 s. ${ }^{31} \mathrm{P}$ NMR spectra were taken in order to monitor the sample for decomposition. The results are shown in Figure S54.

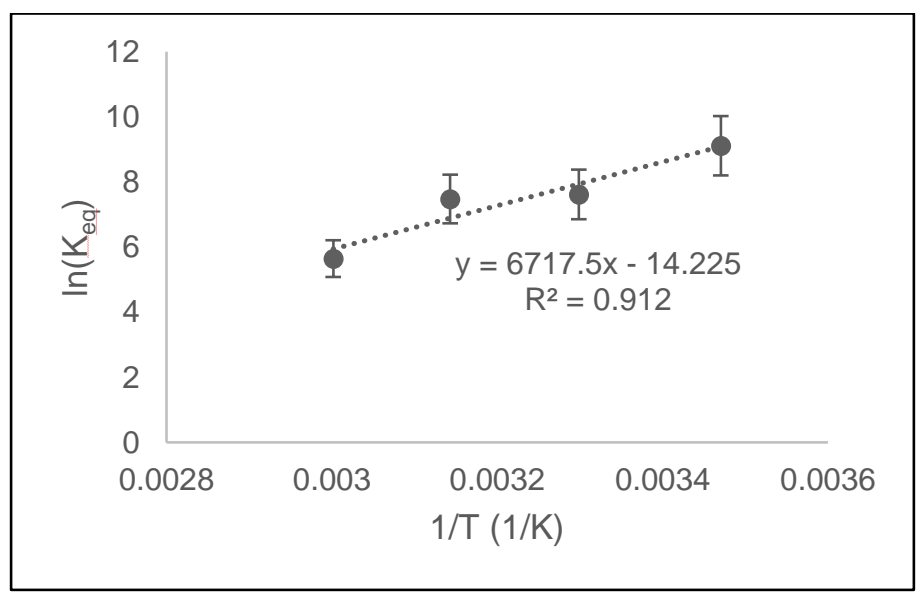

Figure S54. van't Hoff plot for the determination of thermodynamic parameters for 1,2-addition of $\mathrm{H}_{2}$ to 1 to form 2 in THF- $d_{8}$. Data acquired using ${ }^{1} \mathrm{H}$ NMR spectroscopy. 


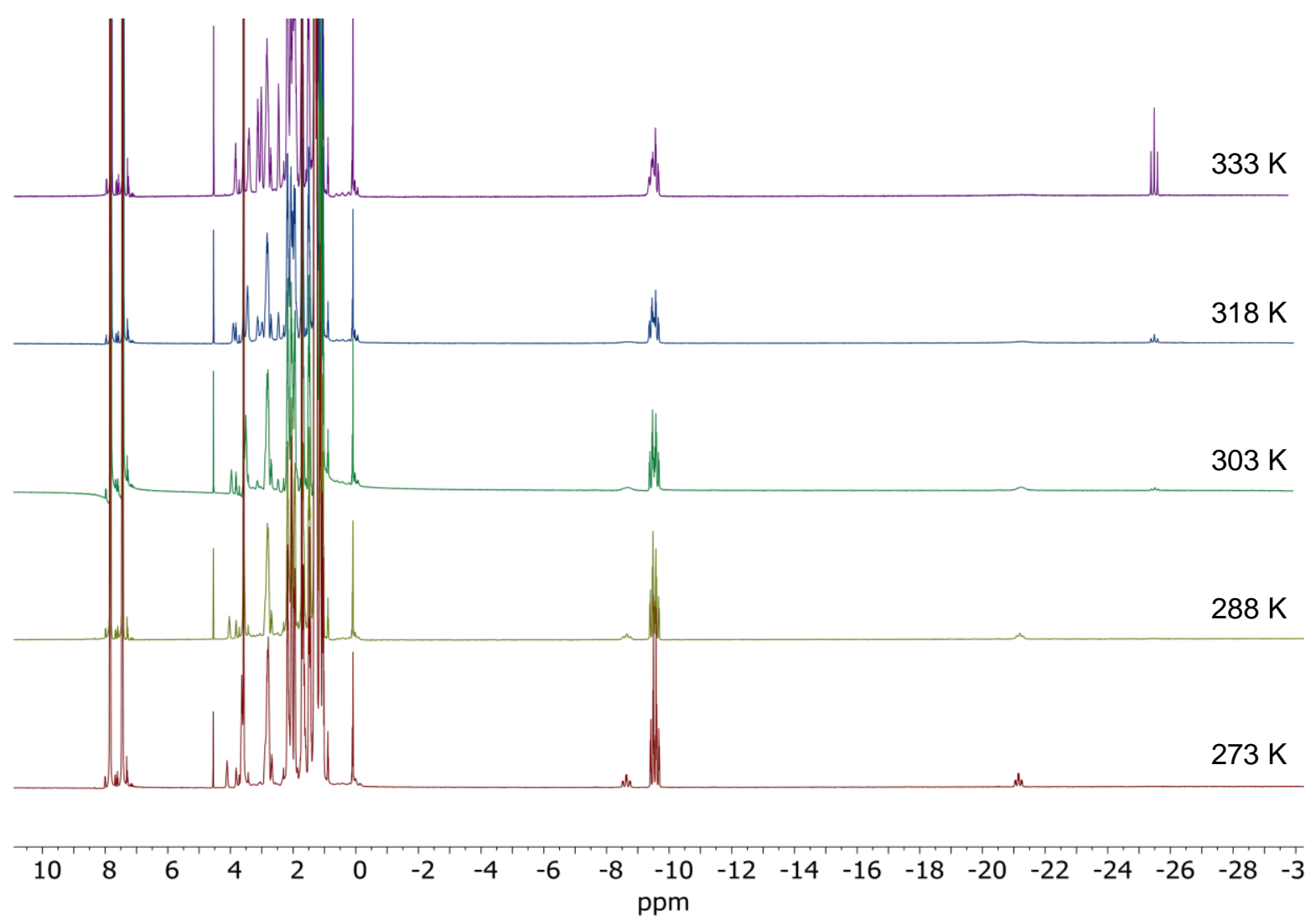

Figure S55: ${ }^{1} \mathrm{H}$ NMR spectra taken at variable temperatures, from $273 \mathrm{~K}$ to $333 \mathrm{~K}$ at $15 \mathrm{~K}$ increments, of the equilibrium between $\mathbf{1}$ and $\mathrm{H}_{2}$ and $\mathbf{2}$ to create the van't Hoff plot in Figure S54. At $273 \mathrm{~K}$ and below, $\mathbf{1}$ is not observable. The diagnostic chemical shift of $\mathbf{1}$ is at $\sim-26 \mathrm{ppm}$, while $\mathbf{2}$ and isomers are at $\sim-8-10$ and $-21.5 \mathrm{ppm}$.

\begin{tabular}{|c|c|c|c|c|c|c|c|c|}
\hline $\begin{array}{c}\text { Temp } \\
\left({ }^{\circ} \mathrm{C}\right)\end{array}$ & $\begin{array}{c}\text { Temp } \\
(\mathrm{K})\end{array}$ & $\begin{array}{c}1 / \mathrm{T} \\
(1 / \mathrm{K})\end{array}$ & $\begin{array}{c}{\left[\mathrm{H}_{2}\right]} \\
(\mathrm{M})^{\mathrm{a}}\end{array}$ & {$[\mathbf{2}](\mathrm{M})$} & {$[\mathbf{1}](\mathrm{M})$} & $\mathrm{K}_{\mathrm{eq}}$ & $\ln \left(\mathrm{K}_{\mathrm{eq}}\right)$ \\
\hline 0 & 273.15 & & 0.0037 & 0.0056 & 0.0443 & 0.0000 & N/A & N/A \\
\hline 15 & 288.15 & & 0.0035 & 0.0058 & 0.0452 & 0.0009 & 9055.4 & 9.111 \\
\hline 30 & 303.15 & & 0.0033 & 0.0061 & 0.0411 & 0.0033 & 2030.7 & 7.616 \\
\hline 45 & 318.15 & & 0.0031 & 0.0063 & 0.0369 & 0.0033 & 1764.9 & 7.476 \\
\hline 60 & 333.15 & & 0.0030 & 0.0065 & 0.0239 & 0.0130 & 282.8 & 5.645 \\
\hline
\end{tabular}

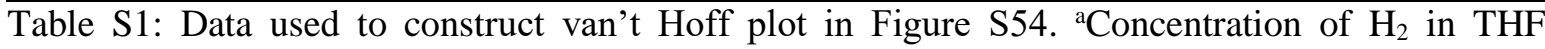
determined by the equation given in Solubility Data Series: Hydrogen and Deuterium, Vol. 5, 1981, Ed. A.S. Kertes, Pergamon Press, Elmsford, NY, pp. 213-220.

$$
K_{e q}=\frac{[2]}{[1]\left[H_{2}\right]}(\text { Eq. S4) }
$$


XII. X-ray Crystallographic Information

$\left[\left({ }^{\mathrm{Pr} P N}{ }^{\mathrm{H}} \mathrm{P}\right) \mathrm{Fe}(\mathrm{H})(\mathrm{CO})\left(\mathrm{N}_{2}\right)\right]\left[\mathrm{BAr}_{4}\right]\left(\mathbf{5}-\mathbf{N}_{2}\right)(\mathrm{CCDC} 2089317)$ :

Low-temperature diffraction data ( $\omega$-scans) were collected on a Rigaku MicroMax-007HF diffractometer coupled to a Saturn994+CCD detector with $\mathrm{Cu} \mathrm{K} \alpha(\lambda=1.54178 \AA)$ for the structure of $\mathbf{5}-\mathbf{N}_{2}$. The diffraction images were processed and scaled using Rigaku Oxford Diffraction software. ${ }^{9}$ The structure was solved with SHELXT and was refined against $\mathrm{F}^{2}$ on all data by full-matrix least squares with SHELXL. ${ }^{10}$ All nonhydrogen atoms were refined anisotropically. Hydrogen atoms were included in the model at geometrically calculated positions and refined using a riding model. The isotropic displacement parameters of all hydrogen atoms were fixed to 1.2 times the $\mathrm{U}$ value of the atoms to which they are linked (1.5 times for methyl groups). There are numerous sites of disorder in the model. The general strategy for modeling these sites was to define two site which model one atom. These sites were grouped into chemically reasonable moieties. The site occupancies for their groups were set with a linked free variable, so no atom's site occupancy totaled to a value more than 1.0. The thermal parameters in the disordered atoms were restrained to be similar and all disordered bond lengths were restrained to be similar to their chemically equivalent counterparts. The full numbering scheme of compound $\mathbf{5 - \mathbf { N } _ { 2 }}$ can be found in the full details of the X-ray structure determination (CIF), which is included as Supporting Information. CCDC number 2089317 contains the supplementary crystallographic data for this paper. These data can be obtained free of charge from The Cambridge Crystallographic Data Center via www.ccdc.cam.ac.uk/data_request/cif.

Table S2. Crystal data and structure refinement for $\mathbf{5}-\mathbf{N}_{\mathbf{2}}$.

Empirical formula

Formula weight

Temperature

Wavelength

Crystal system

Space group

Unit cell dimensions

\section{C53 H60 B F24 Fe N3 O2 P2}

1355.64

93(2) K

\section{$1.54184 \AA$}

Triclinic

P-1

$\mathrm{a}=18.5341(9) \AA \quad \alpha=68.499(4)^{\circ}$

$\mathrm{b}=18.7986(8) \AA \quad \beta=84.050(4)^{\circ}$

$\mathrm{c}=19.1562(9) \AA \quad \gamma=78.947(4)^{\circ}$ 
Volume

$\mathrm{Z}$

Density (calculated)

Absorption coefficient

$\mathrm{F}(000)$

Crystal size

Crystal color and habit

Diffractometer

Theta range for data collection

Index ranges

Reflections collected

Independent reflections

Observed reflections (I > 2sigma(I))

Completeness to theta $=66.601^{\circ}$

Absorption correction

Max. and min. transmission

Solution method

Refinement method

Data / restraints / parameters

Goodness-of-fit on $\mathrm{F}^{2}$

Final $\mathrm{R}$ indices [I $>2 \operatorname{sigma}(\mathrm{I})]$

$\mathrm{R}$ indices (all data)

Extinction coefficient

Largest diff. peak and hole
6090.6(5) $\AA^{3}$

4

$1.478 \mathrm{Mg} / \mathrm{m}^{3}$

$3.526 \mathrm{~mm}^{-1}$

2768

$0.200 \times 0.200 \times 0.050 \mathrm{~mm}^{3}$

Yellow Plate

Rigaku Saturn 944+ CCD

2.431 to $66.601^{\circ}$.

$-22<=\mathrm{h}<=22,-22<=\mathrm{k}<=22,-22<=\mathrm{l}<=22$

200062

$21202[\mathrm{R}(\mathrm{int})=0.2688]$

11046

$98.5 \%$

Semi-empirical from equivalents

1.00000 and 0.32339

SHELXT-2014/5 (Sheldrick, 2014)

SHELXL-2014/7 (Sheldrick, 2014)

21202 / $540 / 1763$

1.015

$\mathrm{R} 1=0.0998, \mathrm{wR} 2=0.2560$

$\mathrm{R} 1=0.1707, \mathrm{wR} 2=0.3116$

$\mathrm{n} / \mathrm{a}$

0.823 and -0.652 e. $\AA^{-3}$ 


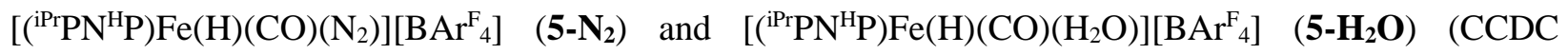
2078925):

Low-temperature diffraction data ( $\omega$-scans) were collected on a Rigaku MicroMax-007HF diffractometer coupled to a Saturn994+CCD detector with $\mathrm{Cu} \operatorname{K} \alpha(\lambda=1.54178 \AA$ ), The diffraction images were processed and scaled using Rigaku Oxford Diffraction software. ${ }^{9}$ The structure was solved with SHELXT and was refined against $\mathrm{F}^{2}$ on all data by full-matrix least squares with SHELXL. ${ }^{10}$ All non-hydrogen atoms were refined anisotropically. Hydrogen atoms were included in the model at geometrically calculated positions and refined using a riding model. The isotropic displacement parameters of all hydrogen atoms were fixed to 1.2 times the $\mathrm{U}$ value of the atoms to which they are linked (1.5 times for methyl and water groups). One $\mathrm{CF}_{3}$ group is disordered over two positions. The chemically equivalent 1,2 C-F and 1,3 F-F distances were restrained to be similar. Their site occupancies were freely refined to converged values of $0.54 / 0.46$. The ether molecules required additional restraints; the thermal parameters were restrained to be similar within each solvent model. The 1,3 distance between carbon atoms C37-C36 were restrained to 2.23. A similar approach was used for the 1,3 distance of H37A-H36A. Without these restraints, the model was unstable in refinement. There are two distinct molecules in the asymmetric unit: $\mathbf{5}-\mathbf{N}_{2}$ and the water adduct $\mathbf{5}-\mathbf{H}_{2} \mathbf{O}$ (Figure S56). 


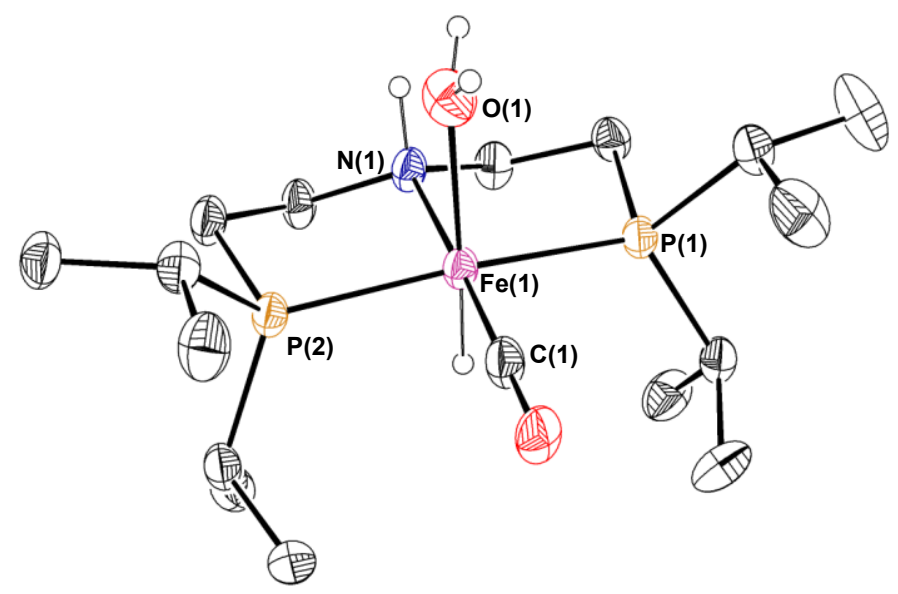

Figure S56. ORTEP of 5-H $\mathbf{H}_{2} \mathrm{O}$. The $\mathrm{BAr}_{4}{ }_{4}$ anion, hydrogen atoms not bound to Fe or N, solvent, and co-crystallized 5- $\mathbf{N}_{2}$ excluded for clarity. Bond distances $(\AA)$ and angles $\left({ }^{\circ}\right)$ : $\mathrm{Fe}(1)-\mathrm{O}(1)$ 2.129(6), $\mathrm{Fe}(1)-\mathrm{C}(1)$ 1.714(7), $\mathrm{Fe}(1)-\mathrm{P}(1)$ 2.219(2), $\mathrm{Fe}(1)-\mathrm{P}(2)$ 2.216(2), $\mathrm{Fe}(1)-\mathrm{N}(1)$ 2.076(6), $\mathrm{N}(2)-\mathrm{N}(3)$ 1.098(11); P(1)-Fe(1)-P(2) 165.59(8).

Table S3. Crystal data and structure refinement for $\mathbf{5}-\mathbf{N}_{2} / \mathbf{5}-\mathbf{H}_{2} \mathbf{O}$.

Empirical formula

Formula weight

Temperature

Wavelength

Crystal system

Space group

Unit cell dimensions

Volume

$\mathrm{Z}$

Density (calculated)

Absorption coefficient

$\mathrm{F}(000)$

Crystal size

Crystal color and habit

Diffractometer

Theta range for data collection

Index ranges

Reflections collected
C110 H132 B2 F48 Fe2 N4 O6 P4

2775.39

93(2) K

$1.54184 \AA$

Orthorhombic

Pna $2_{1}$

$\mathrm{a}=28.9789(2) \AA \quad \alpha=90^{\circ}$

$\mathrm{b}=24.5841(2) \AA \quad \beta=90^{\circ}$

$\mathrm{c}=17.98411(14) \AA \quad \gamma=90^{\circ}$

12812.23(18) $\AA^{3}$

4

$1.439 \mathrm{Mg} / \mathrm{m}^{3}$

$3.372 \mathrm{~mm}^{-1}$

5688

$0.1 \times 0.1 \times 0.1 \mathrm{~mm}^{3}$

Yellow Block

Rigaku Saturn 944+ CCD

2.357 to $66.598^{\circ}$.

$-34<=\mathrm{h}<=34,-29<=\mathrm{k}<=29,-21<=1<=21$

458363 
Independent reflections

Observed reflections (I > 2sigma(I))

Completeness to theta $=25.242^{\circ}$

Absorption correction

Max. and min. transmission

Solution method

Refinement method

Data / restraints / parameters

Goodness-of-fit on $\mathrm{F}^{2}$

Final $\mathrm{R}$ indices [I $>2 \operatorname{sigma}(\mathrm{I})]$

$\mathrm{R}$ indices (all data)

Largest diff. peak and hole
$22642[\mathrm{R}(\mathrm{int})=0.1544]$

19439

$100.0 \%$

Semi-empirical from equivalents

1.00000 and 0.43177

SHELXT-2014/5 (Sheldrick, 2014)

SHELXL-2014/7 (Sheldrick, 2014)

22642 / 95 / 1646

1.021

$\mathrm{R} 1=0.0625, \mathrm{wR} 2=0.1644$

$\mathrm{R} 1=0.0737, \mathrm{wR} 2=0.1744$

0.819 and -0.716 e. $\AA^{-3}$

\section{$\left[\left({ }^{\left({ }^{P r}\right.}{ }^{P N}{ }^{\mathrm{H}} \mathrm{P}\right) \mathrm{Fe}(\mathrm{H})(\mathrm{CO})\left(\mathrm{PMe}_{3}\right)\right]\left[\mathrm{PF}_{6}\right](7)\left(\mathrm{CCDC}_{2078923):}\right.$}

Low-temperature diffraction data ( $\omega$-scans) were collected on a Rigaku MicroMax-007HF diffractometer coupled to a Dectris Pilatus3R detector with Mo $\mathrm{K} \alpha(\lambda=0.71073 \AA)$ for the structure of 7 . The diffraction images were processed and scaled using Rigaku Oxford Diffraction software. ${ }^{9}$ The structure was solved with SHELXT and was refined against $\mathrm{F}^{2}$ on all data by full-matrix least squares with SHELXL. ${ }^{10}$ All nonhydrogen atoms were refined anisotropically. Hydrogen atoms were included in the model at geometrically calculated positions and refined using a riding model. The isotropic displacement parameters of all hydrogen atoms were fixed to 1.2 times the $\mathrm{U}$ value of the atoms to which they are linked (1.5 times for methyl groups). The only exception is $\mathrm{H} 1$, which was found in the difference map and freely refined.

Table S4. Crystal data and structure refinement for 7.

Empirical formula

Formula weight

Temperature

Wavelength

Crystal system

Space group

Unit cell dimensions
C20 H46 F6 Fe N O P4

610.31

93(2) K

$0.71073 \AA$

Monoclinic

$\mathrm{P} 21 / \mathrm{c}$

$\mathrm{a}=13.6020(3) \AA \quad \alpha=90^{\circ}$

$\mathrm{b}=14.9134(3) \AA$ 
Volume

$\mathrm{Z}$

Density (calculated)

Absorption coefficient

$\mathrm{F}(000)$

Crystal size

Crystal color and habit

Diffractometer

Theta range for data collection

Index ranges

Reflections collected

Independent reflections

Observed reflections (I > 2sigma(I))

Completeness to theta $=25.242^{\circ}$

Absorption correction

Max. and min. transmission

Solution method

Refinement method

Data / restraints / parameters

Goodness-of-fit on $\mathrm{F}^{2}$

Final R indices [I $>2 \operatorname{sigma}(\mathrm{I})]$

$\mathrm{R}$ indices (all data)

Largest diff. peak and hole $\mathrm{c}=14.1726(3) \AA \quad \gamma=90^{\circ}$

2865.91(11) $\AA^{3}$

4

$1.414 \mathrm{Mg} / \mathrm{m}^{3}$

$0.803 \mathrm{~mm}^{-1}$

1284

$0.200 \times 0.120 \times 0.090 \mathrm{~mm}^{3}$

Orange Block

Dectris Pilatus 3R

2.884 to $27.482^{\circ}$.

$-17<=\mathrm{h}<=17,-19<=\mathrm{k}<=19,-18<=1<=18$

71581

$6566[\mathrm{R}(\mathrm{int})=0.0403]$

6083

$99.8 \%$

Semi-empirical from equivalents

1.00000 and 0.77657

SHELXT-2014/5 (Sheldrick, 2014)

SHELXL-2014/7 (Sheldrick, 2014)

6566 / 0 / 313

1.200

$\mathrm{R} 1=0.0403, \mathrm{wR} 2=0.0890$

$\mathrm{R} 1=0.0427, \mathrm{wR} 2=0.0896$

0.852 and -0.401 e. $\AA^{-3}$ 
$\left.\left[{ }^{\mathrm{iPr} P N}{ }^{\mathrm{H}} \mathrm{P}\right) \mathrm{Fe}(\mathrm{H})(\mathrm{CO})\left(\mathrm{H}_{2}\right)\right]\left[\mathrm{PF}_{6}\right](\mathbf{8})(\mathrm{CCDC} 2078922)$ :

Low-temperature diffraction data ( $\omega$-scans) were collected on a Rigaku MicroMax-007HF diffractometer coupled to a Saturn994+ CCD detector with $\mathrm{Cu} \operatorname{K} \alpha(\lambda=1.54178 \AA)$ for the structure of $\mathbf{8}$. The diffraction images were processed and scaled using Rigaku Oxford Diffraction software. ${ }^{9}$ The structure was solved with SHELXT and was refined against $\mathrm{F}^{2}$ on all data by full-matrix least squares with SHELXL. ${ }^{10}$ All nonhydrogen atoms were refined anisotropically. Hydrogen atoms were included in the model at geometrically calculated positions and refined using a riding model. The isotropic displacement parameters of all hydrogen atoms were fixed to 1.2 times the $\mathrm{U}$ value of the atoms to which they are linked (1.5 times for methyl groups).

Table S5. Crystal data and structure refinement for $\mathbf{8}$.

Empirical formula

Formula weight

Temperature

Wavelength

Crystal system

Space group

Unit cell dimensions

Volume

Z

Density (calculated)

Absorption coefficient

$\mathrm{F}(000)$

Crystal size

Crystal color and habit

Diffractometer

Theta range for data collection

ndex ranges

Reflections collected

Independent reflections

Observed reflections $(\mathrm{I}>2 \operatorname{sigma}(\mathrm{I})$ )
C23 H43 F6 Fe N O P3

612.34

93(2) K

$1.54184 \AA$

Monoclinic

$\mathrm{P} 21 / \mathrm{m}$

$\mathrm{a}=8.8485(3) \AA$ $\alpha=90^{\circ}$

$\mathrm{b}=13.6148(3) \AA$

$\beta=106.246(4)^{\circ}$

$\mathrm{c}=12.6583(4) \AA$

$\gamma=90^{\circ}$

1464.06(8) $\AA^{3}$

2

$1.389 \mathrm{Mg} / \mathrm{m}^{3}$

$6.175 \mathrm{~mm}^{-1}$

642

$0.130 \times 0.080 \times 0.040 \mathrm{~mm}^{3}$

Colorless Plate

Rigaku Saturn 944+ CCD

3.637 to $66.582^{\circ}$.

$-10<=\mathrm{h}<=10,-16<=\mathrm{k}<=16,-15<=\mathrm{l}<=15$

44504

$2706[\mathrm{R}(\mathrm{int})=0.0653]$

2372 
Completeness to theta $=25.242^{\circ}$

Absorption correction

Max. and min. transmission

Solution method

Refinement method

Data / restraints / parameters

Goodness-of-fit on F2

Final R indices [I>2sigma(I)]

$\mathrm{R}$ indices (all data)

Largest diff. peak and hole
$100.0 \%$

Semi-empirical from equivalents

1.00000 and 0.62845

SHELXT-2014/5 (Sheldrick, 2014)

SHELXL-2014/7 (Sheldrick, 2014)

2706 / 0 / 183

1.107

$\mathrm{R} 1=0.0631, \mathrm{wR} 2=0.1756$

$\mathrm{R} 1=0.0693, \mathrm{wR} 2=0.1837$

2.434 and -0.923 e. $\AA^{-3}$

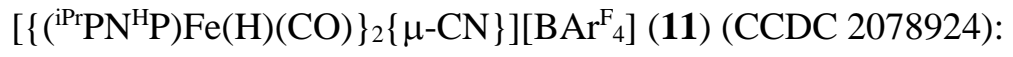

Low-temperature diffraction data ( $\omega$-scans) were collected on a Rigaku MicroMax-007HF diffractometer coupled to a Saturn994+ CCD detector with $\mathrm{Cu} \mathrm{K \alpha}(\lambda=1.54178 \AA)$ for the structure of 11 . The diffraction images were processed and scaled using Rigaku Oxford Diffraction software. ${ }^{9}$ The structure was solved with SHELXT and was refined against $\mathrm{F}^{2}$ on all data by full-matrix least squares with SHELXL. ${ }^{10}$ All nonhydrogen atoms were refined anisotropically. Hydrogen atoms were included in the model at geometrically calculated positions and refined using a riding model. The isotropic displacement parameters of all hydrogen atoms were fixed to 1.2 times the $\mathrm{U}$ value of the atoms to which they are linked (1.5 times for methyl groups). The $\mathrm{CN}$ group is disordered by $180^{\circ}$. The site occupancy for this group was freely refined to converged values of $0.64(7) / 0.36(7)$. The overlapping atoms were restrained to have identical thermal and positional parameters. Several $\mathrm{CF}_{3}$ groups show signs of disorder. Those $\mathrm{CF}_{3}$ groups that were modeled as disordered were restrained to have similar thermal parameters as their neighbors.

Table S6. Crystal data and structure refinement for $\mathbf{1 1 .}$

Empirical formula

Formula weight

Temperature

Wavelength

Crystal system

Space group

Unit cell dimensions
C67 H88 B F24 Fe2 N3 O2 P4

1669.79

93(2) K

$1.54184 \AA$

Orthorhombic

$\mathrm{P} 22_{1} 2_{1}$

$\mathrm{a}=12.8761(2) \AA \quad \alpha=90^{\circ}$. 
Volume

$\mathrm{Z}$

Density (calculated)

Absorption coefficient

$\mathrm{F}(000)$

Crystal size

Crystal color and habit

Diffractometer

Theta range for data collection

Index ranges

Reflections collected

Independent reflections

Observed reflections (I > 2sigma(I))

Completeness to theta $=66.599^{\circ}$

Absorption correction

Max. and min. transmission

Solution method

Refinement method

Data / restraints / parameters

Goodness-of-fit on $\mathrm{F}^{2}$

Final $\mathrm{R}$ indices [I $>2 \operatorname{sigma}(\mathrm{I})]$

$\mathrm{R}$ indices (all data)

Absolute structure parameter

Extinction coefficient

Largest diff. peak and hole $\mathrm{b}=22.7105(3) \AA$

$\mathrm{c}=26.9609(4) \AA$

7884.0(2) $\AA^{3}$

4

$1.407 \mathrm{Mg} / \mathrm{m}^{3}$

$4.603 \mathrm{~mm}^{-1}$

3440

$0.200 \times 0.200 \times 0.140 \mathrm{~mm}^{3}$

Orange Block

Rigaku Saturn 944+ CCD

2.544 to $66.599^{\circ}$.

$-15<=\mathrm{h}<=15,-27<=\mathrm{k}<=27,-32<=\mathrm{l}<=32$

263073

$13911[\mathrm{R}(\mathrm{int})=0.1881]$

11765

$99.9 \%$

Semi-empirical from equivalents

1.00000 and 0.65730

SHELXT-2014/5 (Sheldrick, 2014)

SHELXL-2014/7 (Sheldrick, 2014)

13911 / 36 / 982

1.041

$\mathrm{R} 1=0.0638, \mathrm{wR} 2=0.1701$

$\mathrm{R} 1=0.0746, \mathrm{w} \mathrm{R} 2=0.1823$

$-0.027(3)$

$0.00077(13)$

0.554 and -0.651 e. $\AA^{-3}$

\section{$\left[\left\{\left({ }^{\left({ }^{\mathrm{Pr}} \mathrm{PN}\right.}{ }^{\mathrm{H}} \mathrm{P}\right) \mathrm{Fe}(\mathrm{H})(\mathrm{CO})\right\}_{2}\{\mu-(\mathrm{O}) \mathrm{C}(\mathrm{O}) \mathrm{H}\}\right]\left[\mathrm{PF}_{6}\right](\mathbf{1 2})(\mathrm{CCDC} 2078921)$ :}

Low-temperature diffraction data ( $\omega$-scans) were collected on a Rigaku MicroMax-007HF diffractometer coupled to a Dectris Pilatus3R detector with $\operatorname{Mo} K \alpha(\lambda=0.71073 \AA)$ for the structure of 12 . The diffraction images were processed and scaled using Rigaku Oxford Diffraction software. ${ }^{9}$ The structure was solved with SHELXT and was refined against $\mathrm{F}^{2}$ on all data by full-matrix least squares with SHELXL. ${ }^{10}$ All non- 
hydrogen atoms were refined anisotropically. Hydrogen atoms were included in the model at geometrically calculated positions and refined using a riding model. The isotropic displacement parameters of all hydrogen atoms were fixed to 1.2 times the $\mathrm{U}$ value of the atoms to which they are linked (1.5 times for methyl groups). The $\mathrm{PF}_{6}$ group is disordered over two positions. The site occupancies were freely refined to converged values of $0.763(3) / 0.237(3)$. The major and minor components were distinguished with the suffixes "A" and "B", respectively. All chemically 1,2 P-F distances were restrained to be similar. Some chemically equivalent 1,3 P-F distances were also restrained to be similar. All atoms in the $\mathrm{PF}_{6}$ groups were restrained to have similar atomic displacement parameters. Due to the small amount of electron density in the minor component, the atomic displacement parameter of P5B was constrained to be identical to P5A.

Table S7. Crystal data and structure refinement for $\mathbf{1 2 .}$

Empirical formula

Formula weight

Temperature

Wavelength

Crystal system

Space group

Unit cell dimensions

Volume

Z

Density (calculated)

Absorption coefficient

$\mathrm{F}(000)$

Crystal size

Crystal color and habit

Diffractometer

Theta range for data collection

Index ranges

Reflections collected

Independent reflections

Observed reflections (I > 2sigma(I))
C38 H76 F6 Fe2 N2 O4 P5

1005.55

93(2) K

$0.71073 \AA$

Triclinic

$\mathrm{P}-1$

$\mathrm{a}=10.6141(3) \AA \quad \alpha=67.014(2)^{\circ}$.

$\mathrm{b}=14.8251(4) \AA$

$\beta=85.003(2)^{\circ}$.

$\mathrm{c}=18.0644(5) \AA$

$\gamma=71.737(2)^{\circ}$.
2

$1.345 \mathrm{Mg} / \mathrm{m}^{3}$

$0.805 \mathrm{~mm}^{-1}$

1062

$0.200 \times 0.100 \times 0.050 \mathrm{~mm}^{3}$

Orange Plate

Dectris Pilatus 3R

2.882 to $27.484^{\circ}$.

$-13<=\mathrm{h}<=13,-19<=\mathrm{k}<=19,-23<=\mathrm{l}<=23$

48814

$11351[\mathrm{R}(\mathrm{int})=0.0301]$

9945 
Completeness to theta $=25.242^{\circ}$

Absorption correction

Max. and min. transmission

Solution method

Refinement method

Data / restraints / parameters

Goodness-of-fit on $\mathrm{F}^{2}$

Final $\mathrm{R}$ indices [I $>2 \operatorname{sigma}(\mathrm{I})]$

$\mathrm{R}$ indices (all data)

Largest diff. peak and hole
$99.8 \%$

Semi-empirical from equivalents

1.00000 and 0.72993

SHELXT-2014/5 (Sheldrick, 2014)

SHELXL-2014/7 (Sheldrick, 2014)

$11351 / 235 / 588$

1.060

$\mathrm{R} 1=0.0297, \mathrm{wR} 2=0.0785$

$\mathrm{R} 1=0.0356, \mathrm{wR} 2=0.0811$

0.918 and -0.406 e. $\AA^{-3}$ 


\section{Single Crystal Neutron Diffraction}

Neutron diffraction data for $\mathbf{8}$ were measured on the TOPAZ single-crystal time-of-flight Laue diffractometer at the Spallation Neutron Source (SNS), Oak Ridge National Laboratory. ${ }^{11}$ A plate-shaped crystal of $\mathbf{8}$, with dimensions of $0.4 \times 0.8 \times 1.3 \mathrm{~mm}$ was mounted on the tip of a MiTeGen loop using fluorinated grease and transferred to the TOPAZ goniometer for data collection at $100 \mathrm{~K}$. To ensure good coverage and redundancy, data were collected using 27 crystal orientations optimized with CrystalPlan ${ }^{12}$ software for optimal coverage of symmetry- equivalent reflections of the triclinic cell. Each orientation was measured for approximately $5 \mathrm{hrs}$ with $20 \mathrm{C}$ of proton charge at the beam power of $1.4 \mathrm{MW}$. The integrated raw Bragg intensities were obtained using the 3-D ellipsoidal Q-space integration in accordance with previously reported methods. ${ }^{13}$ Data reduction, including neutron TOF spectrum, Lorentz, and detector efficiency corrections, was carried out with the ANVRED3 program. ${ }^{14}$ Spherical absorption correction was applied with $\mu=0.2912+0.2256 \lambda \mathrm{mm}^{-1}$. The reduced data were saved as SHELX HKLF2 format, in which the wavelength is recorded separately for each reflection, and data were not merged. Starting with the Xray structure at $100 \mathrm{~K}$ as an input model, the neutron crystal structure was refined using the SHELXL2018/3 program. ${ }^{15}$ Owing to the negative neutron scattering length for hydrogen $(-3.74 \mathrm{fm})$ atoms, the nuclear positions dominated by the three missing hydrides appear as strong negative peaks $(-3.83,-3.98$ and $-4.14 f m \AA^{-3}$ ) in the difference Fourier map as shown in Figure S57. The hydrides atoms located from difference Fourier map were included in the refinement of the neutron structure and refined anisotropically to convergence. The data is deposited in the CCDC as 2078926. 


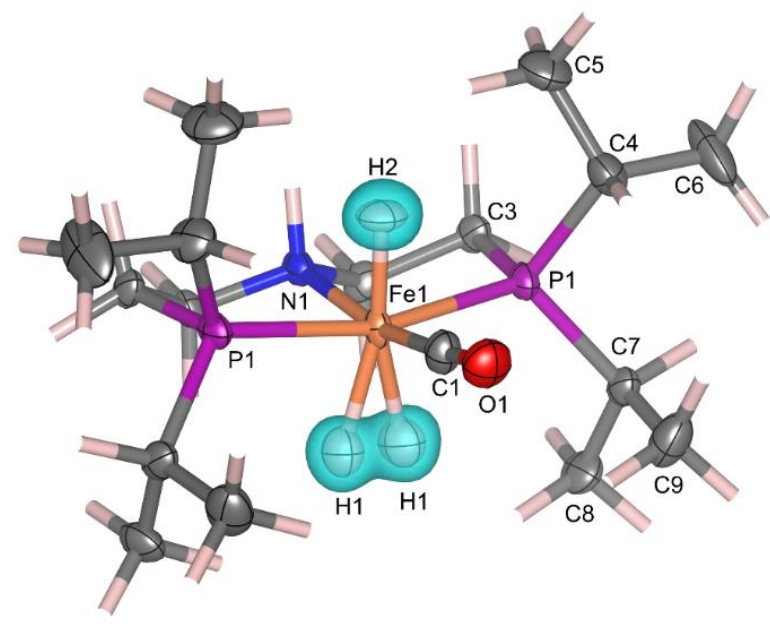

Figure S57. Overlay of the difference Fourier map showing the negative nuclear densities (holes) of the missing hydride atoms $\mathrm{H} 1$ and $\mathrm{H} 2$ (omit map) in 8. Atom displacement ellipsoid is shown at the $30 \%$ probability level. The nuclear densities are plotted with an isosurface level of $-1.2 \mathrm{fm} \AA-3$. Hydrogen atoms on carbon and nitrogen are shown as sticks for clarity. 


\section{Computational Details}

DFT studies were performed to probe the thermodynamics of ligand binding to the cation $\mathbf{5}$ as well as for intermediates along proposed decomposition pathways. The calculations were carried out with the Gaussian16 software package. ${ }^{16}$ The hybrid meta-GGA M06 functional ${ }^{17}$ was selected on the basis of previous geometry and energy benchmarking. ${ }^{18}$ Structures were fully optimized without any geometry or symmetry constraints, using the double-z LANL2DZ for iron, including pseudopotentials, ${ }^{19}$ and $6-31+\mathrm{G}^{* *}$ for all other elements ${ }^{20}$ basis sets. Vibrational frequencies were computed at the same level of theory to classify all stationary points as either saddle points (transition states with a single imaginary frequency) or energy minima (reactants, products, and intermediates with only real frequencies). These calculations were also used to obtain the thermochemistry corrections (zero-point, thermal, and entropy energies). The energies reported in the text were obtained by adding the thermochemistry corrections at $298.15 \mathrm{~K}$ to the refined potential energies. Solvation effects of THF were included using the continuum CPCM model.

\section{Selected Structures of Key Intermediates:}

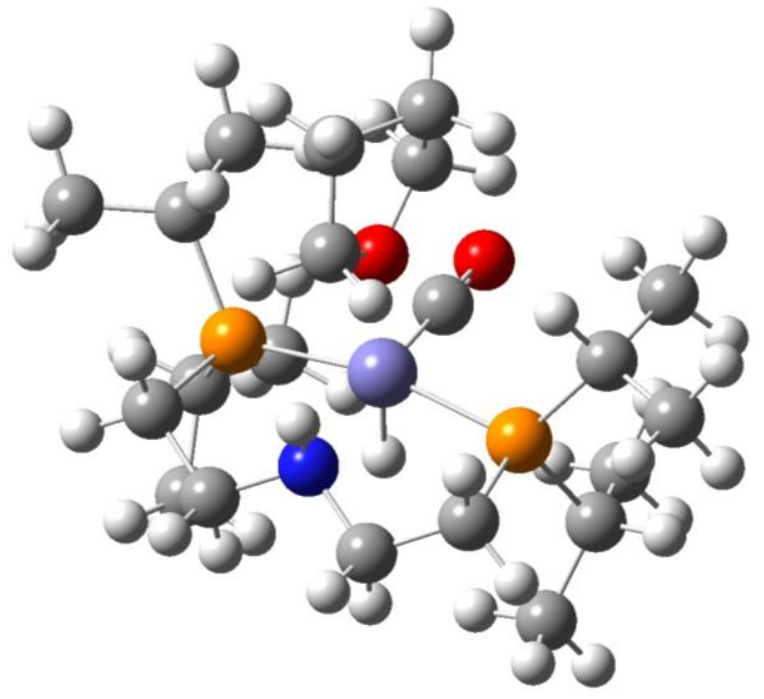

Figure S58. DFT-optimized structure of 5-THF. 


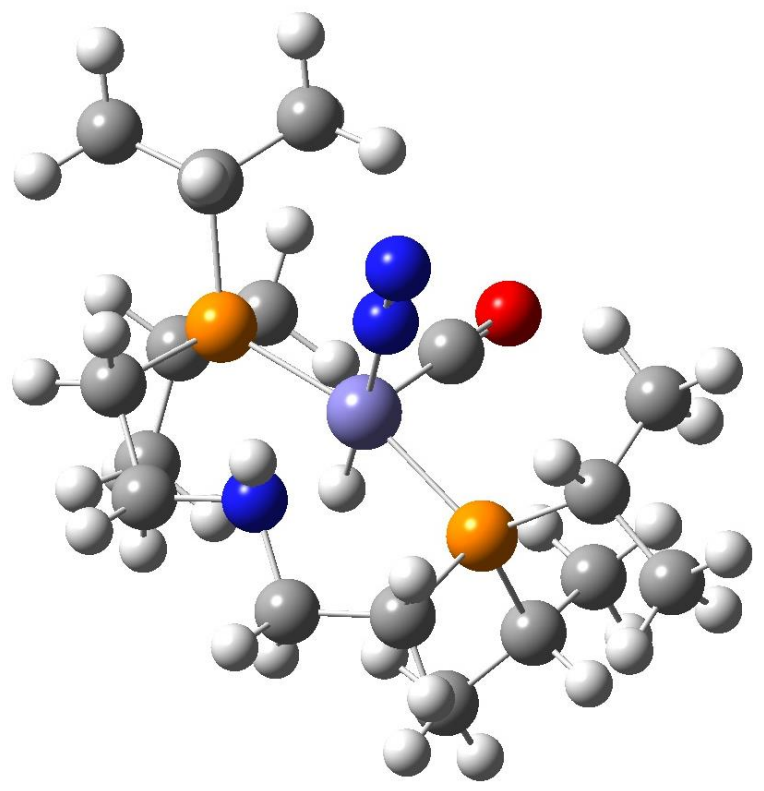

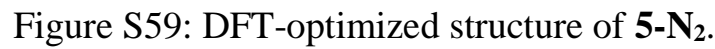

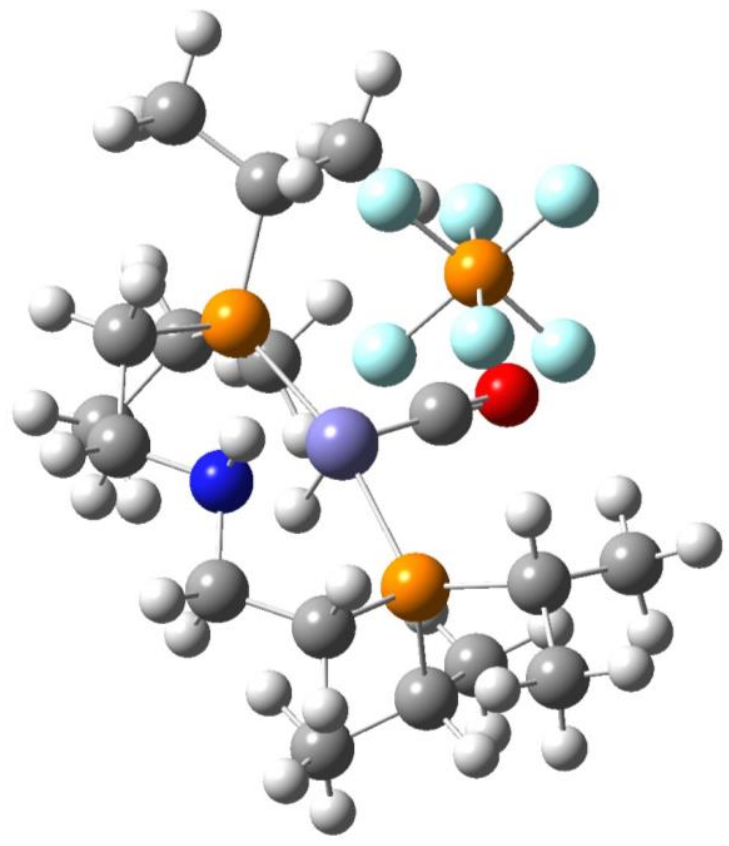

Figure S60: DFT-optimized structure of 6. 


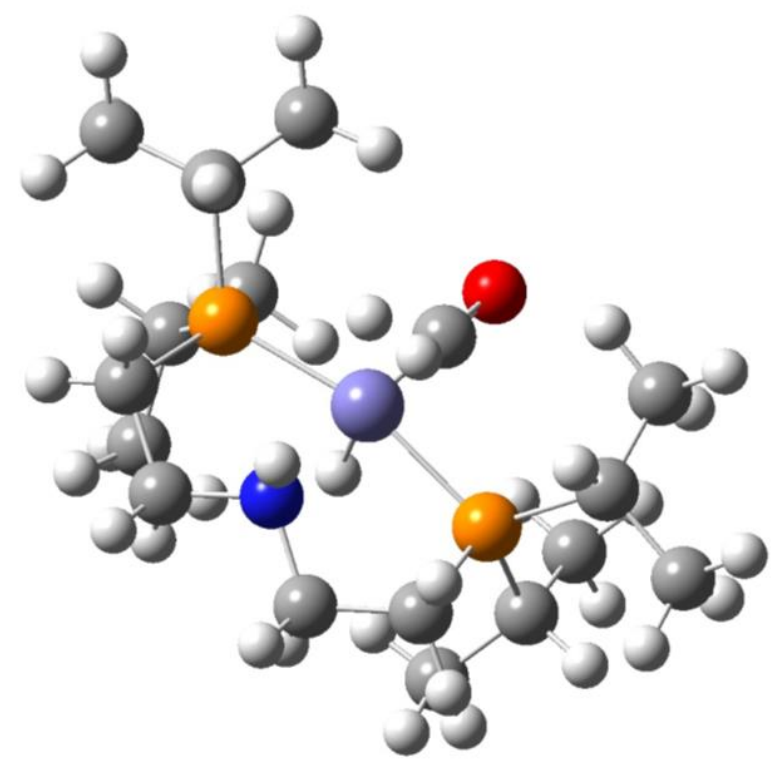

Figure S61: DFT-optimized structure of 8.

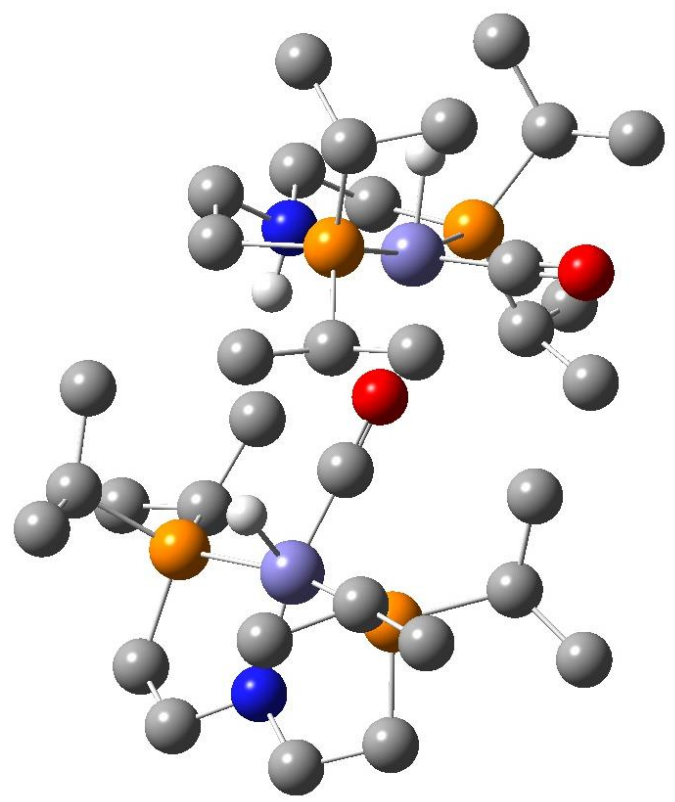

Figure S62: DFT-optimized structure of dimerization of 5 and 1. Hydrogens not bound to Fe or $\mathrm{N}$ omitted for clarity. 


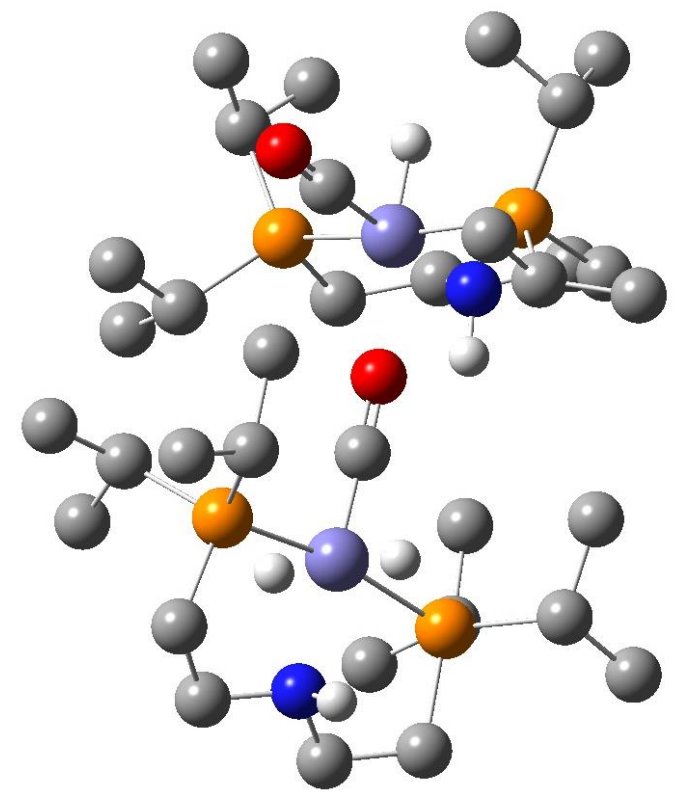

Figure S63: DFT-optimized structure of dimerization of 5 and 2. Hydrogens not bound to Fe or $\mathrm{N}$ omitted for clarity.

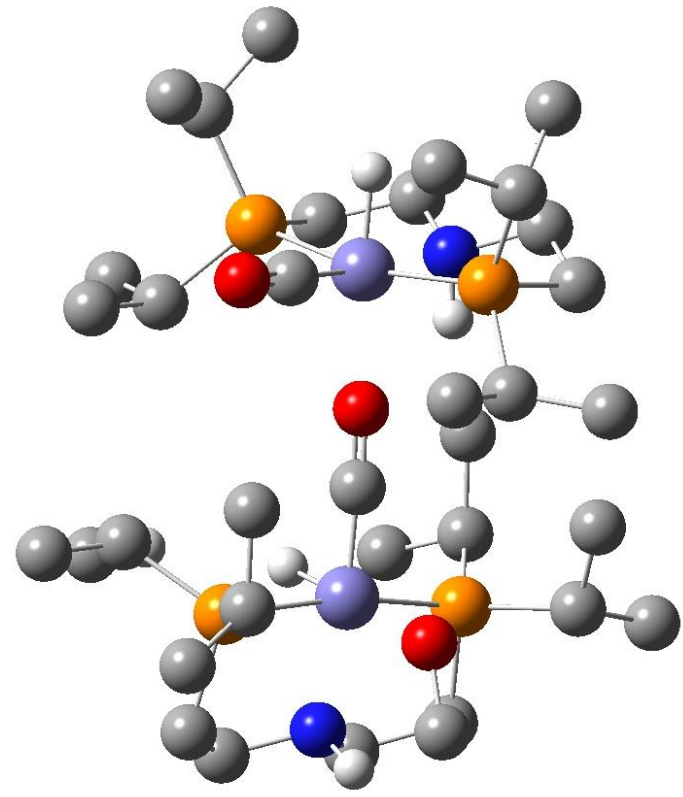

Figure S64: DFT-optimized structure of dimerization of 5 and 9. Hydrogens not bound to Fe or $\mathrm{N}$ omitted for clarity. 


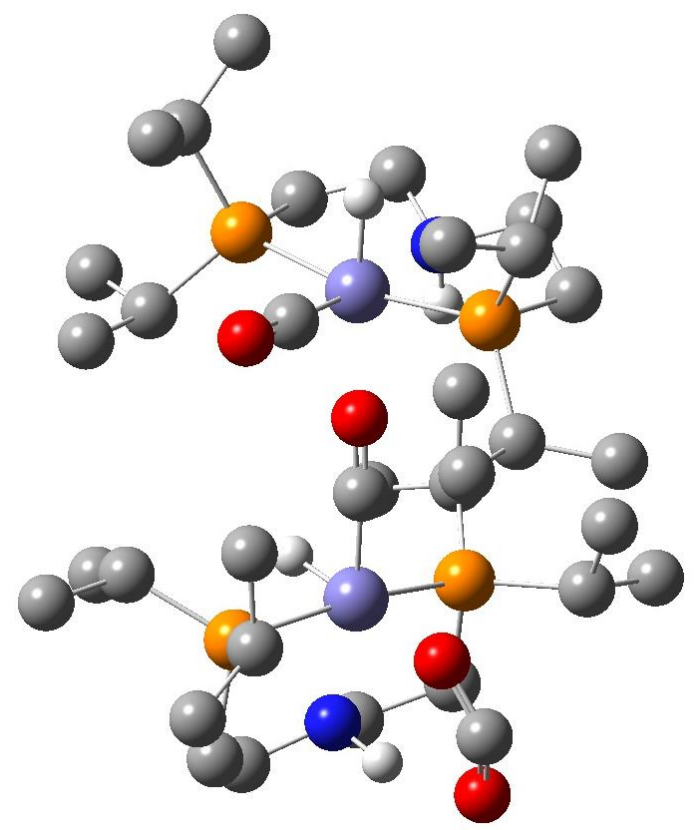

Figure S65 DFT-optimized structure of dimerization of $\mathbf{5}$ and $\mathbf{1 0}$ via the carbonyl group. Hydrogens not bound to Fe or $\mathrm{N}$ omitted for clarity.

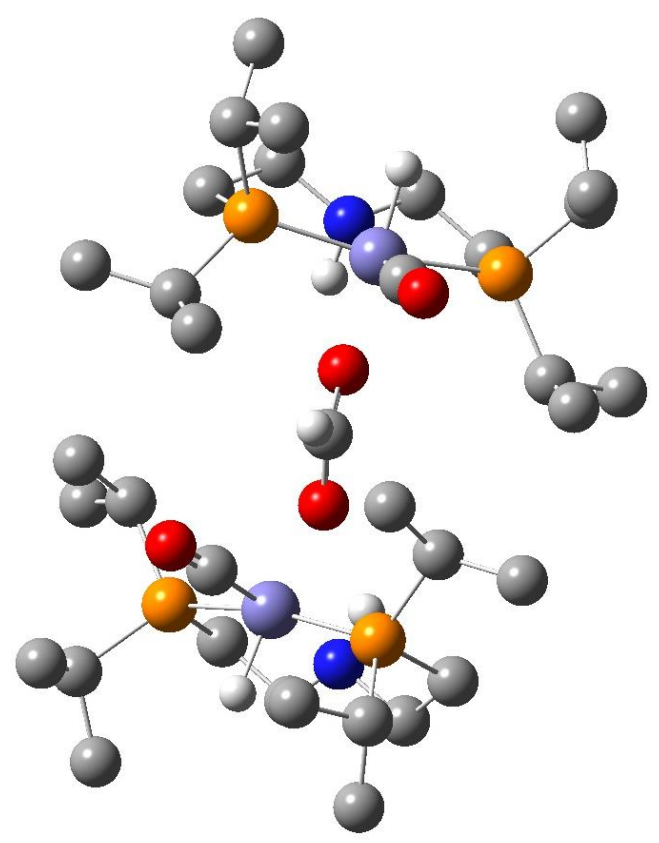

Figure S66: DFT-optimized structure of dimerization of $\mathbf{5}$ and $\mathbf{1 0}$ to form $\mathbf{1 2}$. Hydrogens not bound to $\mathrm{Fe}$, part of the formate anion, or $\mathrm{N}$ omitted for clarity. 
Optimized Coordinates and DFT Energies (Using M06 unless otherwise noted)

$\begin{array}{lrrr}\mathrm{N}_{2} & \mathrm{G}_{\mathrm{THF}}=-68694.74306 \mathrm{kcal} / \mathrm{mol} & \\ \mathrm{N} & 0.00000000 & 0.00000000 & 0.55249500 \\ \mathrm{~N} & 0.00000000 & 0.00000000 & -0.55249500 \\ & & & \\ \mathrm{CO} & \mathrm{G}_{\mathrm{THF}}=-71075.75631 \mathrm{kcal} / \mathrm{mol} & \\ \mathrm{O} & 0.00000000 & 0.00000000 & 0.48748900 \\ \mathrm{C} & 0.00000000 & 0.00000000 & -0.64998500 \\ & & & \\ \mathrm{THF} & \mathrm{G}_{\mathrm{THF}}=-145709.5018 \mathrm{kcal} / \mathrm{mol} & \\ \mathrm{C} & 1.17587200 & -0.44821900 & 0.00000000 \\ \mathrm{O} & 0.00083200 & -1.26384200 & 0.00000000 \\ \mathrm{C} & -1.17529500 & -0.44978700 & 0.00000000 \\ \mathrm{C} & -0.76197000 & 1.01809200 & 0.00000100 \\ \mathrm{C} & 0.76059000 & 1.01910600 & 0.00000100 \\ \mathrm{H} & 1.76090800 & -0.72257400 & 0.91513200 \\ \mathrm{H} & 1.76090800 & -0.72257400 & -0.91513200 \\ \mathrm{H} & -1.75975200 & -0.72461500 & -0.91536000 \\ \mathrm{H} & -1.75975200 & -0.72461500 & 0.91536000 \\ \mathrm{H} & -1.16363700 & 1.54171600 & -0.90190200 \\ \mathrm{H} & -1.16363800 & 1.54171400 & 0.90190500 \\ \mathrm{H} & 1.16155900 & 1.54326600 & -0.90190200 \\ \mathrm{H} & 1.16156000 & 1.54326500 & 0.90190500\end{array}$

$\begin{array}{cccc}\left({ }^{\mathrm{iPr}} \mathrm{PNP}\right) \mathrm{Fe}(\mathrm{H})(\mathrm{CO})(\mathbf{1}) & \mathrm{G}_{\mathrm{THF}}=-1007261.718 \mathrm{kcal} / \mathrm{mol} \\ \mathrm{Fe} & -0.00226800 & -0.02190100 & -0.07776400 \\ \mathrm{O} & 0.10883100 & -1.08396800 & -2.76052600 \\ \mathrm{P} & -2.18111100 & -0.01280200 & 0.08940300 \\ \mathrm{~N} & -0.00476400 & -0.26157100 & 1.74628900 \\ \mathrm{C} & -1.18800800 & -0.37058000 & 2.60251800 \\ \mathrm{H} & -1.29578900 & 0.55479400 & 3.20097800 \\ \mathrm{H} & -1.03909000 & -1.17840200 & 3.34194000 \\ \mathrm{C} & -2.45891200 & -0.63165500 & 1.80816200 \\ \mathrm{H} & -3.34518000 & -0.18462300 & 2.27706900 \\ \mathrm{H} & -2.63860700 & -1.71133800 & 1.72809500 \\ \mathrm{P} & 2.16874200 & 0.12640700 & 0.10321800 \\ \mathrm{C} & -3.21423300 & -1.11612500 & -0.99927700 \\ \mathrm{H} & -3.02909500 & -0.73211400 & -2.01546100 \\ \mathrm{C} & -2.70867400 & -2.55437100 & -0.94217500 \\ \mathrm{H} & -2.93457300 & -3.01839600 & 0.02689700 \\ \mathrm{H} & -1.62658800 & -2.62118200 & -1.10345400 \\ \mathrm{H} & -3.20671800 & -3.15774300 & -1.71085900 \\ \mathrm{C} & -4.70774200 & -1.05544300 & -0.70126600 \\ \mathrm{H} & -5.24986300 & -1.76002800 & -1.34463700 \\ \mathrm{H} & -5.13472100 & -0.06115000 & -0.87127600 \\ \mathrm{H} & -4.91504400 & -1.33933300 & 0.33944000 \\ \mathrm{C} & -3.05390200 & 1.62768700 & 0.02601800 \\ \mathrm{H} & -4.08480500 & 1.44612600 & 0.36937900 \\ \mathrm{C} & -3.07810200 & 2.17746500 & -1.39401900 \\ \mathrm{H} & -3.63396000 & 1.53514700 & -2.08723400\end{array}$




\begin{tabular}{|c|c|c|c|}
\hline $\mathrm{H}$ & -2.05529200 & 2.28754300 & -1.77923200 \\
\hline $\mathrm{H}$ & -3.55003000 & 3.16782900 & -1.41014500 \\
\hline $\mathrm{C}$ & -2.38622800 & 2.61130600 & 0.97910900 \\
\hline $\mathrm{H}$ & -2.37898800 & 2.24856800 & 2.01420500 \\
\hline $\mathrm{H}$ & -2.91820100 & 3.57098600 & 0.96645500 \\
\hline $\mathrm{H}$ & -1.34649800 & 2.79446400 & 0.67684800 \\
\hline $\mathrm{C}$ & 1.18041800 & -0.32141100 & 2.60731200 \\
\hline $\mathrm{H}$ & 1.35264900 & -1.36855000 & 2.92009300 \\
\hline $\mathrm{H}$ & 0.99318800 & 0.23652000 & 3.54261100 \\
\hline $\mathrm{C}$ & 2.42200300 & 0.23931500 & 1.92935400 \\
\hline $\mathrm{H}$ & 3.34241600 & -0.25784400 & 2.26051900 \\
\hline $\mathrm{H}$ & 2.52975300 & 1.30580400 & 2.16279500 \\
\hline $\mathrm{C}$ & 3.08450700 & 1.58371400 & -0.60028900 \\
\hline $\mathrm{H}$ & 4.10585300 & 1.54259300 & -0.18881800 \\
\hline $\mathrm{C}$ & 2.43515800 & 2.89696200 & -0.18094400 \\
\hline $\mathrm{H}$ & 1.41561900 & 2.96502800 & -0.58174000 \\
\hline $\mathrm{H}$ & 3.01389000 & 3.74261900 & -0.57305800 \\
\hline $\mathrm{H}$ & 2.37400300 & 3.01566300 & 0.90720600 \\
\hline $\mathrm{H}$ & -0.05223900 & 1.26161700 & -0.84712000 \\
\hline $\mathrm{C}$ & 3.13736600 & 1.48243500 & -2.12090000 \\
\hline $\mathrm{H}$ & 3.68393600 & 0.59950900 & -2.47158200 \\
\hline $\mathrm{H}$ & 3.63062000 & 2.36629700 & -2.54381400 \\
\hline $\mathrm{H}$ & 2.12131200 & 1.43800400 & -2.53603700 \\
\hline $\mathrm{C}$ & 3.16231500 & -1.34770100 & -0.45410300 \\
\hline $\mathrm{H}$ & 2.96332600 & -1.41566600 & -1.53560000 \\
\hline $\mathrm{C}$ & 2.60908400 & -2.60492300 & 0.20890500 \\
\hline $\mathrm{H}$ & 1.53117600 & -2.71344700 & 0.03693500 \\
\hline $\mathrm{H}$ & 2.77936400 & -2.58641100 & 1.29411600 \\
\hline $\mathrm{H}$ & 3.11284500 & -3.49628400 & -0.18483700 \\
\hline $\mathrm{C}$ & 4.66341700 & -1.22328100 & -0.22711900 \\
\hline $\mathrm{H}$ & 4.89660800 & -1.08200900 & 0.83670400 \\
\hline $\mathrm{H}$ & 5.11048400 & -0.39113500 & -0.78176900 \\
\hline $\mathrm{H}$ & 5.16936100 & -2.14238600 & -0.54898400 \\
\hline $\mathrm{C}$ & 0.05421600 & -0.64222500 & -1.67360300 \\
\hline \multicolumn{2}{|c|}{ 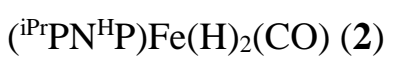 } & \multicolumn{2}{|c|}{$\mathrm{G}_{\mathrm{THF}}=-1008011.947 \mathrm{kcal} / \mathrm{mol}$} \\
\hline $\mathrm{Fe}$ & 0.00167500 & -0.00603800 & -0.05534200 \\
\hline $\mathrm{C}$ & 0.00902800 & -1.59112000 & 0.55569600 \\
\hline $\mathrm{O}$ & 0.01207700 & -2.68667200 & 0.98833300 \\
\hline $\mathrm{N}$ & -0.00592800 & 1.96615000 & -0.78268200 \\
\hline $\mathrm{C}$ & 1.19452800 & 2.72932300 & -0.39675800 \\
\hline $\mathrm{H}$ & 1.19570000 & 3.71863100 & -0.88237300 \\
\hline $\mathrm{C}$ & 2.43327700 & 1.93522900 & -0.75767600 \\
\hline $\mathrm{P}$ & 2.18327200 & 0.20396100 & -0.12410100 \\
\hline $\mathrm{C}$ & 3.26167000 & -0.82052400 & -1.25567900 \\
\hline $\mathrm{C}$ & 2.80496400 & -0.74194000 & -2.70774500 \\
\hline $\mathrm{C}$ & 3.28164600 & -2.27668900 & -0.80057800 \\
\hline $\mathrm{C}$ & 3.12016600 & 0.28340800 & 1.49625700 \\
\hline $\mathrm{C}$ & 4.63631700 & 0.36601000 & 1.35761100 \\
\hline $\mathrm{C}$ & 2.71174300 & -0.80710500 & 2.47902800 \\
\hline $\mathrm{C}$ & -1.24017500 & 2.71043000 & -0.47277700 \\
\hline
\end{tabular}




$\begin{array}{lrrr}\mathrm{C} & -2.44759900 & 1.86831200 & -0.83245800 \\ \mathrm{H} & -3.37911000 & 2.32921700 & -0.47941900 \\ \mathrm{P} & -2.17885300 & 0.16319200 & -0.13666700 \\ \mathrm{C} & -2.76834400 & -2.36525500 & -1.29466700 \\ \mathrm{C} & -4.62504400 & -0.66548100 & -1.37599400 \\ \mathrm{C} & -3.24351700 & 0.16485800 & 1.40023100 \\ \mathrm{C} & -3.15022400 & -1.16763000 & 2.13489400 \\ \mathrm{C} & -2.87761300 & 1.30910400 & 2.33796100 \\ \mathrm{H} & -4.89925500 & 0.39619400 & -1.42084700 \\ \mathrm{H} & -5.09556500 & -1.09903100 & -0.48339700 \\ \mathrm{H} & -5.07288600 & -1.16023900 & -2.24780100 \\ \mathrm{H} & -3.23302700 & -2.90150700 & -2.13265500 \\ \mathrm{H} & -3.13723700 & -2.82842000 & -0.37047500 \\ \mathrm{H} & -1.68544700 & -2.52179700 & -1.34487500 \\ \mathrm{H} & -4.27777200 & 0.31779500 & 1.05399100 \\ \mathrm{H} & -3.46676700 & -2.01698900 & 1.51859000 \\ \mathrm{H} & -3.78851500 & -1.15238800 & 3.02802900 \\ \mathrm{H} & -2.12054200 & -1.35795900 & 2.46511600 \\ \mathrm{H} & -3.49228700 & 1.25520500 & 3.24609700 \\ \mathrm{H} & -1.82212000 & 1.24608300 & 2.63455600 \\ \mathrm{H} & -3.04709600 & 2.29465900 & 1.88760300 \\ \mathrm{H} & 1.62500000 & -0.82776600 & 2.61458600 \\ \mathrm{H} & 3.03151000 & -1.80238300 & 2.14389500 \\ \mathrm{H} & 3.18010100 & -0.62656900 & 3.45563000 \\ \mathrm{H} & 2.75318700 & 1.24193000 & 1.90105200 \\ \mathrm{H} & 5.06359300 & -0.59066600 & 1.02941700 \\ \mathrm{H} & 4.96011100 & 1.13881600 & 0.64915700 \\ \mathrm{H} & 5.08754700 & 0.60270400 & 2.33003700 \\ \mathrm{H} & 0.05230200 & 0.63483700 & 1.38076900 \\ \mathrm{H} & -1.21901800 & 2.92425900 & 0.60401200 \\ \mathrm{H} & -2.52569000 & 1.76911800 & -1.92514400 \\ \mathrm{H} & -1.24952200 & 3.67517900 & -1.00505100 \\ \mathrm{H} & 0.02654400 & 1.81760200 & -1.79272900 \\ \mathrm{H} & 2.26895900 & -2.70150400 & -0.82311900 \\ \mathrm{H} & 3.67653500 & -2.40364200 & 0.21385400 \\ \mathrm{H} & 3.90749900 & -2.87556300 & -1.47490200 \\ \mathrm{H} & -2.11651500 & -0.88381100 & -1.37180900 \\ \mathrm{H} & -0.05677900 & -0.48371700 & -1.55794300\end{array}$

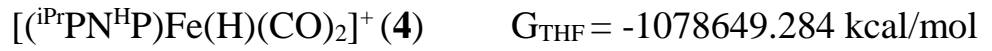
$\begin{array}{cccc}\mathrm{Fe} & 0.00084400 & 0.20569500 & -0.08132300 \\ \mathrm{H} & 0.01247200 & -1.20462900 & 0.48375300 \\ \mathrm{P} & -2.22016700 & -0.10310200 & -0.08289900\end{array}$ 


$\begin{array}{lrrr}\mathrm{N} & -0.06772900 & -0.73407700 & -1.94211600 \\ \mathrm{O} & -0.06236900 & 0.88417300 & 2.73021800 \\ \mathrm{C} & -1.20980300 & -1.67471700 & -2.06960900 \\ \mathrm{H} & -0.99441600 & -2.51969100 & -1.40414700 \\ \mathrm{H} & -1.25948700 & -2.05970000 & -3.09793200 \\ \mathrm{P} & 2.20082100 & -0.12034400 & -0.17490100 \\ \mathrm{C} & -2.50182600 & -0.99245500 & -1.67787600 \\ \mathrm{H} & -3.32812700 & -1.70942700 & -1.60749700 \\ \mathrm{H} & -2.78298300 & -0.24970200 & -2.43418600 \\ \mathrm{C} & 1.18496400 & -1.42378700 & -2.34708100 \\ \mathrm{H} & 1.17007200 & -1.60730700 & -3.42965500 \\ \mathrm{H} & 1.18015200 & -2.40039400 & -1.85075400 \\ \mathrm{C} & 2.40492000 & -0.62871700 & -1.93857000 \\ \mathrm{H} & 2.48406300 & 0.29431800 & -2.52980600 \\ \mathrm{H} & 3.32349100 & -1.20554200 & -2.10278300 \\ \mathrm{C} & -2.89879600 & -1.20275500 & 1.26438100 \\ \mathrm{H} & -2.52516300 & -0.74961400 & 2.19584400 \\ \mathrm{C} & -2.34396400 & -2.62058500 & 1.16990200 \\ \mathrm{H} & -1.24898100 & -2.64734500 & 1.15935700 \\ \mathrm{H} & -2.71453400 & -3.13644100 & 0.27423100 \\ \mathrm{H} & -2.68276800 & -3.19973800 & 2.03629400 \\ \mathrm{C} & -4.42399200 & -1.24125400 & 1.30303500 \\ \mathrm{H} & -4.74879500 & -1.96954900 & 2.05516200 \\ \mathrm{H} & -4.84519400 & -1.56149500 & 0.34058500 \\ \mathrm{H} & -4.87150200 & -0.27899800 & 1.56933700 \\ \mathrm{C} & 2.98012900 & -1.46341300 & 0.84643000 \\ \mathrm{H} & 4.05844100 & -1.37835900 & 0.64325300 \\ \mathrm{C} & -3.17509200 & 2.17500000 & 1.16756100 \\ \mathrm{H} & -3.29881200 & 1.58252600 & 2.08192700 \\ \mathrm{H} & -3.90564000 & 2.99115600 & 1.20256200 \\ \mathrm{H} & -2.17530600 & 2.62872000 & 1.19061800 \\ \mathrm{H} & -3.21199600 & 2.23512900 & -1.34093300 \\ \mathrm{H} & -2.20813000 & 2.66585200 & -1.41728200 \\ \mathrm{H} & 2.00431000 & 2.48959900 & 1.32567300 \\ \mathrm{H} & & & \end{array}$




$\begin{array}{lrrr}\mathrm{H} & 3.63263600 & 3.14774600 & 1.12805900 \\ \mathrm{C} & 4.78378900 & 1.04465500 & -0.20292100 \\ \mathrm{H} & 5.35507300 & 1.97308000 & -0.31845700 \\ \mathrm{H} & 4.99113200 & 0.41790600 & -1.07796700 \\ \mathrm{H} & 5.17421600 & 0.53451500 & 0.68647000 \\ \mathrm{C} & -0.02085400 & 0.64759100 & 1.59849900 \\ \mathrm{C} & 0.12245000 & 1.87192000 & -0.72773900 \\ \mathrm{O} & 0.27745800 & 2.96088600 & -1.08202600\end{array}$

$\left[\left({ }^{\mathrm{PPr} P N}{ }^{\mathrm{H}} \mathrm{P}\right) \mathrm{Fe}(\mathrm{H})(\mathrm{CO})\left(\mathrm{N}_{2}\right)\right]^{+}\left(\mathbf{5}-\mathbf{N}_{\mathbf{2}}\right) \quad \mathrm{G}_{\mathrm{THF}}=-1076248.454 \mathrm{kcal} / \mathrm{mol}$

$\mathrm{Fe}$

$\begin{array}{lllll}\mathrm{P} & 2.21385000 & 0.14168800 & -0.15063700\end{array}$

$\mathrm{P} \quad-2.21377300 \quad 0.14244100 \quad-0.15017800$

$\begin{array}{llll}\mathrm{O} & -0.00044500 & -1.68223500 & 2.29428400\end{array}$

$\mathrm{N} \quad-0.00005700 \quad 1.20016000 \quad-1.75699300$

$\mathrm{H} \quad-0.00185600 \quad 0.61765300 \quad-2.59796000$

$\mathrm{N} \quad \begin{array}{llll}0.00018300 & -1.57170800 & -1.39865200\end{array}$

$\begin{array}{llll}\mathrm{C} & 3.01196500 & 1.07117400 & 1.24659700\end{array}$

$\begin{array}{llll}\text { C } & -2.53586400 & 2.51448100 & 1.33186200\end{array}$

$\begin{array}{llll}\mathrm{H} & -1.45039000 & 2.56916300 & 1.49195400\end{array}$

$\begin{array}{llll}\mathrm{H} & -3.01845400 & 3.00364100 & 2.18630900\end{array}$

$\begin{array}{llll}\mathrm{H} & -2.78798100 & 3.09876700 & 0.44036900\end{array}$

C $\quad 3.28436000 \quad-1.33861500 \quad-0.51423300$

$\begin{array}{llll}\mathrm{C} & -3.28457300 & -1.33679700 & -0.51732800\end{array}$

$\mathrm{H} \quad-2.98796100 \quad-1.57409500 \quad-1.55215900$

$\begin{array}{llll}\mathrm{N} & 0.00048300 & -2.40545600 & -2.14242200\end{array}$

C $\quad-1.21424000 \quad 2.05042800 \quad-1.82767200$

$\begin{array}{lllr}\mathrm{C} & 2.53667300 & 2.51685800 & 1.32655300\end{array}$

$\begin{array}{llll}\text { C } & -0.00019600 & -1.09481400 & 1.29569800\end{array}$

C $\quad-4.77559400 \quad-1.02027900 \quad-0.50167600$

$\mathrm{H} \quad-5.02821200 \quad-0.13778300 \quad-1.10126600$

C $\quad 4.77551000 \quad-1.02263300 \quad-0.49818400$

$\begin{array}{llll}\mathrm{C} & 2.79399300 & 0.36975700 & 2.58150000\end{array}$

$\begin{array}{llll}\text { C } & -3.01195900 & 1.06923900 & 1.24881600\end{array}$

$\begin{array}{llll}\mathrm{H} & -4.08597200 & 1.07314600 & 1.00731100\end{array}$

$\begin{array}{llll}\text { C } & -2.96307400 & -2.55040700 & 0.34736700\end{array}$

$\begin{array}{llll}\text { C } & 2.96181600 & -2.55048300 & 0.35251500\end{array}$

$\begin{array}{llll}\mathrm{C} & 1.21574400 & 2.04789600 & -1.83092800\end{array}$

$\begin{array}{llll}\text { C } & 2.45805100 & 1.20409800 & -1.64482900\end{array}$

$\begin{array}{llll}\text { C } & -2.79506900 & 0.36508000 & 2.58243400\end{array}$

$\begin{array}{llll}\mathrm{C} & -2.45775700 & 1.20837900 & -1.64193900\end{array}$

$\begin{array}{llll}\mathrm{H} & 0.00035400 & 1.03333100 & 0.74544700\end{array}$

$\mathrm{H} \quad-1.90478800 \quad-2.82895100 \quad 0.30085600$

$\mathrm{H} \quad-3.54824200 \quad-3.41048800 \quad 0.00124300$

$\mathrm{H} \quad-3.22346500 \quad-2.38621000 \quad 1.39977100$

$\mathrm{H} \quad-5.33707500 \quad-1.86932700 \quad-0.90881500$

$\mathrm{H} \quad-5.13633000 \quad-0.85477400 \quad 0.52126200$

$\mathrm{H} \quad-3.13343000 \quad-0.67672900 \quad 2.58021200$

$\mathrm{H} \quad-2.59775800 \quad 0.53660700 \quad-2.50086900$

$\mathrm{H} \quad-3.35554300 \quad 1.83390800 \quad-1.56617300$

$\mathrm{H} \quad-1.23491200 \quad 2.59056200 \quad-2.78444300$ 


$\begin{array}{lrrr}\mathrm{H} & -1.12264100 & 2.79550700 & -1.02867800 \\ \mathrm{H} & 1.23625500 & 2.58598100 & -2.78884700 \\ \mathrm{H} & 1.12653700 & 2.79487100 & -1.03346400 \\ \mathrm{H} & 2.59594300 & 0.53021500 & -2.50246000 \\ \mathrm{H} & 3.35695900 & 1.82830900 & -1.57142600 \\ \mathrm{H} & 2.79002200 & 3.09933400 & 0.43423400 \\ \mathrm{H} & 1.45108100 & 2.57257400 & 1.48553300 \\ \mathrm{H} & 3.01879100 & 3.00726600 & 2.18053800 \\ \mathrm{H} & 3.34736500 & 0.89535500 & 3.36839200 \\ \mathrm{H} & 4.08608100 & 1.07397200 & 1.00558800 \\ \mathrm{H} & 1.73261400 & 0.38448000 & 2.86013700 \\ \mathrm{H} & 3.13208400 & -0.67215000 & 2.58159900 \\ \mathrm{H} & 5.02885800 & -0.14139600 & -1.09930000 \\ \mathrm{H} & 5.13567900 & -0.85531700 & 0.52465500 \\ \mathrm{H} & 3.22064400 & -2.38408300 & 1.40496000 \\ \mathrm{H} & 5.33689700 & -1.87268400 & -0.90334900 \\ \mathrm{H} & 3.54758800 & -3.41117300 & 0.00895100 \\ \mathrm{H} & 1.90362900 & -2.82923300 & 0.30500900 \\ \mathrm{H} & 2.98847300 & -1.57784800 & -1.54881400 \\ \mathrm{H} & -3.34883900 & 0.88925400 & 3.36999500 \\ \mathrm{H} & -1.73388900 & 0.37891100 & 2.86182400\end{array}$

$\begin{array}{crrr}\left.\left[{ }^{\mathrm{iPr} P N}{ }^{\mathrm{H}} \mathrm{P}\right) \mathrm{Fe}(\mathrm{H})(\mathrm{CO})\left(\mathrm{N}_{2}\right)\right]^{+}\left(\mathbf{5}-\mathbf{N}_{2}-\mathbf{a n t i}\right) & \mathrm{G}_{\mathrm{THF}}=-1076244.992 \mathrm{kcal} / \mathrm{mol} \\ \mathrm{Fe} & 0.00002100 & -0.07909100 & 0.06224200 \\ \mathrm{P} & -2.21227300 & 0.06881200 & -0.31063700 \\ \mathrm{P} & 2.21239700 & 0.06829200 & -0.31065500 \\ \mathrm{O} & 0.00039700 & 1.80517900 & 2.26650000 \\ \mathrm{~N} & 0.00007700 & -1.15833500 & -1.70393800 \\ \mathrm{H} & 0.00067300 & -0.42898500 & -2.42041400 \\ \mathrm{C} & -3.46781200 & -0.55618100 & 0.91320100 \\ \mathrm{C} & 3.44093600 & -2.07176700 & 1.06903000 \\ \mathrm{H} & 2.51029100 & -2.41693100 & 1.53152700 \\ \mathrm{H} & 4.25967600 & -2.37745600 & 1.73106300 \\ \mathrm{H} & 3.57534600 & -2.60658100 & 0.12275500 \\ \mathrm{C} & -2.82631100 & 1.72159300 & -0.91255800 \\ \mathrm{C} & 2.82617600 & 1.72059000 & -0.91411900 \\ \mathrm{H} & 2.26746600 & 1.82200600 & -1.85872000 \\ \mathrm{C} & 1.23727200 & -1.94573800 & -1.90077600 \\ \mathrm{C} & -3.44142800 & -2.07273000 & 1.06642000 \\ \mathrm{C} & 0.00024300 & 1.03210500 & 1.40491400 \\ \mathrm{C} & 4.31978700 & 1.72550400 & -1.21834500 \\ \mathrm{H} & 4.63628700 & 0.86901300 & -1.82557100 \\ \mathrm{C} & -4.31980200 & 1.72641200 & -1.21738200 \\ \mathrm{C} & -3.28141300 & 0.12074500 & 2.26580300 \\ \mathrm{C} & 3.46797600 & -0.55542500 & 0.91373400 \\ \mathrm{H} & 4.44449200 & -0.27205800 & 0.49293300 \\ \mathrm{C} & 2.44020100 & 2.89408600 & -0.02367800 \\ \mathrm{C} & -2.44101700 & 2.89430000 & -0.02079700 \\ \mathrm{C} & -1.23765200 & -1.94466100 & -1.90170000 \\ \mathrm{C} & -2.42211000 & -1.00197500 & -1.81450800 \\ \mathrm{C} & 3.28224400 & 0.12333800 & 2.26548100\end{array}$




$\begin{array}{lrrr}\mathrm{C} & 2.42241900 & -1.00390300 & -1.81353100 \\ \mathrm{H} & 1.35778900 & 2.95810200 & 0.12654400 \\ \mathrm{H} & 2.76723200 & 3.82883000 & -0.49424100 \\ \mathrm{H} & 2.92284600 & 2.84356800 & 0.95983700 \\ \mathrm{H} & 4.57885200 & 2.63642400 & -1.77040400 \\ \mathrm{H} & 4.91287900 & 1.72918700 & -0.29516800 \\ \mathrm{H} & 3.34948500 & 1.21540800 & 2.20831600 \\ \mathrm{H} & 2.44086000 & -0.34357900 & -2.69154100 \\ \mathrm{H} & 3.37344200 & -1.54728400 & -1.80192200 \\ \mathrm{H} & 1.20595400 & -2.46004200 & -2.87150100 \\ \mathrm{H} & 1.27212000 & -2.71634500 & -1.11977200 \\ \mathrm{H} & -1.20629600 & -2.45851100 & -2.87266400 \\ \mathrm{H} & -1.27340100 & -2.71563400 & -1.12108900 \\ \mathrm{H} & -2.43943900 & -0.34091600 & -2.69199000 \\ \mathrm{H} & -3.37356600 & -1.54463200 & -1.80397200 \\ \mathrm{H} & -3.57683300 & -2.60613500 & 0.11949300 \\ \mathrm{H} & -2.51064800 & -2.41909100 & 1.52775300 \\ \mathrm{H} & -4.25985600 & -2.37890000 & 1.72861900 \\ \mathrm{H} & -4.05343100 & -0.22197700 & 2.96460300 \\ \mathrm{H} & -4.44432700 & -0.27182700 & 0.49307300 \\ \mathrm{H} & -2.30621200 & -0.13804000 & 2.69936600 \\ \mathrm{H} & -3.34845900 & 1.21290500 & 2.21011800 \\ \mathrm{H} & -4.63588200 & 0.87038700 & -1.82547300 \\ \mathrm{H} & -4.91327700 & 1.72920000 & -0.29445400 \\ \mathrm{H} & -2.92394000 & 2.84262000 & 0.96251900 \\ \mathrm{H} & -4.57881800 & 2.63775100 & -1.76877700 \\ \mathrm{H} & -2.76824300 & 3.82940600 & -0.49050300 \\ \mathrm{H} & -1.35867600 & 2.95857400 & 0.12981200 \\ \mathrm{H} & -2.26727100 & 1.82414400 & -1.85684300 \\ \mathrm{H} & 4.05445200 & -0.21863600 & 2.96443700 \\ \mathrm{H} & 2.30715300 & -0.13471200 & 2.69973600 \\ \mathrm{~N} & -0.00012700 & -1.64651900 & 1.08013900 \\ \mathrm{~N} & -0.00030000 & -2.57000200 & 1.70958800 \\ \mathrm{H} & -0.00009400 & 1.15535500 & -0.79605800\end{array}$

$\begin{array}{cccc}{\left[\left({ }^{\mathrm{iPr} P N}{ }^{\mathrm{H}} \mathrm{P}\right) \mathrm{Fe}(\mathrm{H})(\mathrm{CO})(\mathrm{THF})\right]^{+}(\mathbf{5}-\mathbf{T H F})} & \mathrm{G}_{\mathrm{THF}}=-1153264.122 \mathrm{kcal} / \mathrm{mol} \\ \mathrm{Fe} & -0.00426300 & -0.25490500 & -0.02786500 \\ \mathrm{P} & 2.20969500 & -0.44661600 & 0.15346500 \\ \mathrm{P} & -2.21609500 & -0.43213200 & 0.13489400 \\ \mathrm{O} & -0.00667500 & -0.23281200 & -2.91451900 \\ \mathrm{~N} & -0.01116200 & -0.48524900 & 2.04666800 \\ \mathrm{H} & 0.00530800 & 0.47059200 & 2.40916300 \\ \mathrm{C} & 3.05590700 & -1.96089600 & -0.52721100 \\ \mathrm{C} & -2.79497600 & -3.18210700 & 0.31347200 \\ \mathrm{H} & -1.71998200 & -3.40753400 & 0.34610600 \\ \mathrm{H} & -3.29649900 & -4.04939100 & -0.13249700 \\ \mathrm{H} & -3.16370500 & -3.08598500 & 1.34022500 \\ \mathrm{C} & 3.28124900 & 1.00286300 & -0.31699700 \\ \mathrm{C} & -3.26426400 & 1.02360700 & -0.36658800 \\ \mathrm{H} & -2.69881600 & 1.86897200 & 0.06233700 \\ \mathrm{C} & -1.23576600 & -1.12311100 & 2.58773700\end{array}$




\begin{tabular}{|c|c|c|c|}
\hline $\mathrm{C}$ & 2.77163300 & -3.20265100 & 0.31046100 \\
\hline $\mathrm{C}$ & -0.00431300 & -0.22646300 & -1.74844500 \\
\hline $\mathrm{C}$ & -4.66798900 & 1.01313500 & 0.22782500 \\
\hline $\mathrm{H}$ & -4.66919700 & 0.97444600 & 1.32200200 \\
\hline $\mathrm{C}$ & 4.66417000 & 0.98676100 & 0.32494300 \\
\hline $\mathrm{C}$ & 2.64687700 & -2.21937900 & -1.97397400 \\
\hline $\mathrm{C}$ & -3.06485800 & -1.94788300 & -0.54024300 \\
\hline $\mathrm{H}$ & -4.14371600 & -1.72716300 & -0.50902400 \\
\hline $\mathrm{C}$ & -3.32278100 & 1.20329500 & -1.87981500 \\
\hline $\mathrm{C}$ & 3.39896200 & 1.17797400 & -1.82754000 \\
\hline $\mathrm{C}$ & 1.19598800 & -1.15477000 & 2.58663300 \\
\hline $\mathrm{C}$ & 2.43471600 & -0.52352300 & 1.99097300 \\
\hline $\mathrm{C}$ & -2.64389000 & -2.22596900 & -1.97993300 \\
\hline $\mathrm{C}$ & -2.46449700 & -0.49139400 & 1.97035800 \\
\hline $\mathrm{H}$ & -0.00637300 & -1.74327000 & -0.12869400 \\
\hline $\mathrm{H}$ & -2.33664500 & 1.14123000 & -2.35583300 \\
\hline $\mathrm{H}$ & -3.75245400 & 2.18279300 & -2.12221900 \\
\hline $\mathrm{H}$ & -3.96961500 & 0.44572300 & -2.34039400 \\
\hline $\mathrm{H}$ & -5.20171700 & 1.92403100 & -0.07022400 \\
\hline $\mathrm{H}$ & -5.25353200 & 0.16231900 & -0.14322400 \\
\hline $\mathrm{H}$ & -2.79255000 & -1.37440700 & -2.65120700 \\
\hline $\mathrm{H}$ & -2.57130700 & 0.54680700 & 2.31708000 \\
\hline $\mathrm{H}$ & -3.38065700 & -1.02028700 & 2.25942600 \\
\hline $\mathrm{H}$ & -1.24871700 & -1.04133900 & 3.68411500 \\
\hline $\mathrm{H}$ & -1.17494300 & -2.18879100 & 2.33648800 \\
\hline $\mathrm{H}$ & 1.20077200 & -1.09345000 & 3.68452100 \\
\hline $\mathrm{H}$ & 1.12179900 & -2.21431900 & 2.31390700 \\
\hline $\mathrm{H}$ & 2.53371300 & 0.51294000 & 2.34620600 \\
\hline $\mathrm{H}$ & 3.34702500 & -1.05438300 & 2.28819300 \\
\hline $\mathrm{H}$ & 3.12926800 & -3.11810400 & 1.34217600 \\
\hline $\mathrm{H}$ & 1.69549900 & -3.42403600 & 0.32906800 \\
\hline $\mathrm{H}$ & 3.27456700 & -4.06748500 & -0.13871700 \\
\hline $\mathrm{H}$ & 3.22679400 & -3.05859000 & -2.37653000 \\
\hline $\mathrm{H}$ & 4.13562800 & -1.74644900 & -0.48344600 \\
\hline $\mathrm{H}$ & 1.58493700 & -2.49312800 & -2.02556700 \\
\hline $\mathrm{H}$ & 2.80413500 & -1.35924200 & -2.63254000 \\
\hline $\mathrm{H}$ & 4.62840900 & 0.96802900 & 1.41889200 \\
\hline $\mathrm{H}$ & 5.25214500 & 0.12306000 & -0.01111900 \\
\hline $\mathrm{H}$ & 4.07777600 & 0.42957100 & -2.25631100 \\
\hline $\mathrm{H}$ & 5.21804300 & 1.88637700 & 0.02923800 \\
\hline $\mathrm{H}$ & 3.82004600 & 2.16432500 & -2.05683900 \\
\hline $\mathrm{H}$ & 2.43774300 & 1.09422800 & -2.34870300 \\
\hline $\mathrm{H}$ & 2.70576100 & 1.85082200 & 0.09215800 \\
\hline $\mathrm{H}$ & -3.22321900 & -3.06853700 & -2.37623200 \\
\hline $\mathrm{H}$ & -1.58248200 & -2.50384700 & -2.01885300 \\
\hline $\mathrm{O}$ & 0.01320100 & 1.91421900 & 0.21103000 \\
\hline $\mathrm{C}$ & 0.05158500 & 2.77515900 & -0.94525600 \\
\hline $\mathrm{C}$ & -0.09245500 & 2.70495400 & 1.40798700 \\
\hline $\mathrm{C}$ & 0.40503300 & 4.14200400 & -0.40242400 \\
\hline $\mathrm{H}$ & 0.78584600 & 2.36812900 & -1.64793800 \\
\hline $\mathrm{H}$ & -0.93891000 & 2.76762900 & -1.42637100 \\
\hline
\end{tabular}




$\begin{array}{lrrr}\mathrm{C} & -0.31668700 & 4.13142500 & 0.93936300 \\ \mathrm{H} & -0.92466300 & 2.32575100 & 2.01689700 \\ \mathrm{H} & 0.84416100 & 2.60593200 & 1.97981200 \\ \mathrm{H} & 0.08272200 & 4.95004400 & -1.06410100 \\ \mathrm{H} & 1.49018600 & 4.22683700 & -0.25793100 \\ \mathrm{H} & -1.38813000 & 4.32006000 & 0.79591100 \\ \mathrm{H} & 0.06643200 & 4.86514700 & 1.65297100\end{array}$

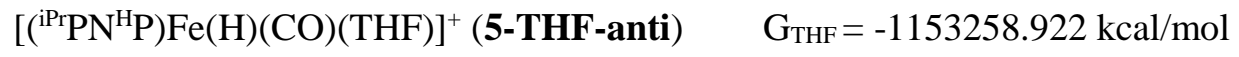

$\begin{array}{llll}\mathrm{Fe} & 0.00675200 & -0.29877500 & 0.04381500\end{array}$

$\begin{array}{llll}\mathrm{P} & -2.20974100 & -0.61255200 & 0.30912400\end{array}$

$\begin{array}{llll}\mathrm{P} & 2.21649600 & -0.62983500 & 0.28852700\end{array}$

$\begin{array}{llll}\mathrm{O} & -0.00359800 & -0.73565300 & -2.81438100\end{array}$

$\begin{array}{llll}\mathrm{N} & 0.00832400 & -0.30254400 & 2.12391500\end{array}$

$\begin{array}{llll}\mathrm{H} & -0.03033800 & -1.30856300 & 2.30595500\end{array}$

$\begin{array}{llll}\mathrm{C} & -3.56106200 & 0.48010700 & -0.36327000\end{array}$

$\begin{array}{llll}\mathrm{C} & 3.33509900 & 1.92327300 & 0.22147900\end{array}$

$\begin{array}{llll}\mathrm{H} & 2.38807300 & 2.33363500 & -0.14564600\end{array}$

$\begin{array}{llll}\mathrm{H} & 4.14286600 & 2.58311400 & -0.11668000\end{array}$

$\begin{array}{llll}\mathrm{H} & 3.32215900 & 1.95786100 & 1.31765900\end{array}$

$\begin{array}{llll}\text { C } & -2.78727700 & -2.36412200 & 0.02109200\end{array}$

$\begin{array}{llll}\mathrm{C} & 2.81180000 & -2.35530300 & -0.10140600\end{array}$

$\begin{array}{llll}\mathrm{H} & 2.24292500 & -2.95201300 & 0.62996900\end{array}$

$\begin{array}{llll}\mathrm{C} & 1.26110100 & 0.17524100 & 2.74674800\end{array}$

$\begin{array}{llll}\text { C } & -3.37273100 & 1.91999800 & 0.09347300\end{array}$

$\begin{array}{llll}\mathrm{C} & 0.00150100 & -0.52935300 & -1.66858600\end{array}$

$\begin{array}{llll}\mathrm{C} & 4.30063100 & -2.55100400 & 0.16040400\end{array}$

$\begin{array}{llll}\mathrm{H} & 4.60856000 & -2.19839800 & 1.15202400\end{array}$

$\begin{array}{llll}\text { C } & -4.27290300 & -2.56364000 & 0.29709200\end{array}$

C $\quad-3.64881500 \quad 0.40107800 \quad-1.88219300$

$\begin{array}{llll}\text { C } & 3.54898900 & 0.51813900 & -0.32415200\end{array}$

$\begin{array}{lllll}\mathrm{H} & 4.49370100 & 0.12235000 & 0.07912000\end{array}$

C $\quad 2.42023100 \quad-2.84441800 \quad-1.49016800$

$\begin{array}{llll}\text { C } & -2.39057500 & -2.92433200 & -1.33908800\end{array}$

$\begin{array}{llll}\text { C } & -1.21352500 & 0.27492400 & 2.72348700\end{array}$

$\begin{array}{llll}\text { C } & -2.41773500 & -0.45094400 & 2.15570500\end{array}$

$\begin{array}{llll}\text { C } & 3.61666700 & 0.53276600 & -1.84607200\end{array}$

$\begin{array}{llll}\mathrm{C} & 2.42694300 & -0.57893700 & 2.13959100\end{array}$

$\begin{array}{llll}\mathrm{H} & 0.01293100 & -1.78426500 & 0.14109800\end{array}$

$\mathrm{H} \quad 1.33517000 \quad-2.83575200 \quad-1.63202500$

$\mathrm{H} \quad 2.76846100 \quad-3.87545100 \quad-1.62652700$

$\mathrm{H} \quad 2.87030900 \quad-2.24154400 \quad-2.28813100$

$\mathrm{H} \quad 4.54929600 \quad-3.61712400 \quad 0.09731000$

$\mathrm{H} \quad 4.91171600 \quad-2.03325300 \quad-0.58953800$

$\mathrm{H} \quad 3.92797000 \quad-0.43045300 \quad-2.26359200$

$\mathrm{H} \quad 2.43043600 \quad-1.61644400 \quad 2.50172700$

$\begin{array}{llll}\mathrm{H} & 3.38632000 & -0.13424900 & 2.42870500\end{array}$

$\begin{array}{llll}\mathrm{H} & 1.21827800 & 0.03714600 & 3.83687600\end{array}$

$\begin{array}{llll}\mathrm{H} & 1.34289300 & 1.25176500 & 2.55824000\end{array}$

$\begin{array}{llll}\mathrm{H} & -1.17607500 & 0.19000100 & 3.81934400\end{array}$

$\begin{array}{llll}\mathrm{H} & -1.23665900 & 1.34326700 & 2.47701000\end{array}$ 


$\begin{array}{rrrr}\mathrm{H} & -2.47513800 & -1.46414800 & 2.57702800 \\ \mathrm{H} & -3.35332500 & 0.05669800 & 2.41661900 \\ \mathrm{H} & -3.32427600 & 2.01892100 & 1.18492900 \\ \mathrm{H} & -2.45223900 & 2.33914100 & -0.32672400 \\ \mathrm{H} & -4.21199800 & 2.53419800 & -0.25352400 \\ \mathrm{H} & -4.39076600 & 1.11878300 & -2.25248700 \\ \mathrm{H} & -4.49401000 & 0.09292300 & 0.07450600 \\ \mathrm{H} & -2.68799800 & 0.65070400 & -2.35278700 \\ \mathrm{H} & -3.94766400 & -0.59072000 & -2.23685200 \\ \mathrm{H} & -4.58413000 & -2.15582800 & 1.26636100 \\ \mathrm{H} & -4.89191500 & -2.09992700 & -0.48116700 \\ \mathrm{H} & -2.85801100 & -2.37871500 & -2.16754600 \\ \mathrm{H} & -4.50771800 & -3.63474200 & 0.29866200 \\ \mathrm{H} & -2.71583500 & -3.96905100 & -1.41417100 \\ \mathrm{H} & -1.30618600 & -2.89857200 & -1.48616300 \\ \mathrm{H} & -2.20954600 & -2.91154800 & 0.78377300 \\ \mathrm{H} & 4.33985900 & 1.28535100 & -2.18275900 \\ \mathrm{H} & 2.64360600 & 0.79130900 & -2.28612600 \\ \mathrm{C} & -0.05615900 & 2.47526500 & -1.48645200 \\ \mathrm{O} & -0.02817300 & 1.94705100 & -0.14368900 \\ \mathrm{C} & -0.01755800 & 3.03055700 & 0.80378500 \\ \mathrm{C} & 0.32180500 & 4.27419300 & 0.00533100 \\ \mathrm{C} & -0.30933000 & 3.96399800 & -1.34646200 \\ \mathrm{H} & 0.91319000 & 2.26214200 & -1.96265900 \\ \mathrm{H} & -0.83934400 & 1.95265900 & -2.04848800 \\ \mathrm{H} & -1.01288100 & 3.11274200 & 1.26698300 \\ \mathrm{H} & 0.71658500 & 2.80768100 & 1.58562300 \\ \mathrm{H} & -0.07152500 & 5.18155900 & 0.47133800 \\ \mathrm{H} & 1.40892500 & 4.38589200 & -0.09195800 \\ \mathrm{H} & -1.38648900 & 4.17217600 & -1.32314900 \\ \mathrm{H} & 0.12628100 & 4.53439000 & -2.17098600\end{array}$

\begin{tabular}{cccc}
$\left.\left[{ }_{\left({ }^{\mathrm{Pr}} \mathrm{PN}\right.}^{\mathrm{H}} \mathrm{P}\right) \mathrm{Fe}(\mathrm{H})(\mathrm{CO})\right]^{+}(\mathbf{5})$ & \multicolumn{2}{c}{$\mathrm{G}_{\mathrm{THF}}=-1007545.198 \mathrm{kcal} / \mathrm{mol}$} \\
$\mathrm{Fe}$ & -0.00001100 & -0.08262000 & -0.30146100 \\
$\mathrm{P}$ & 2.22019600 & 0.12686500 & -0.21261900 \\
$\mathrm{P}$ & -2.22019800 & 0.12686800 & -0.21262400 \\
$\mathrm{O}$ & -0.00003800 & -2.83584300 & 0.57393300 \\
$\mathrm{~N}$ & 0.00000800 & 1.87475400 & -0.90496400 \\
$\mathrm{H}$ & 0.00006600 & 1.78308600 & -1.92757700 \\
$\mathrm{C}$ & 3.02675200 & 0.07139000 & 1.46373100 \\
$\mathrm{C}$ & -2.71319300 & 1.31800800 & 2.28406800 \\
$\mathrm{H}$ & -1.63068600 & 1.42086500 & 2.44493800 \\
$\mathrm{H}$ & -3.18206100 & 1.23102900 & 3.27147300 \\
$\mathrm{H}$ & -3.08806200 & 2.23973500 & 1.82632600 \\
$\mathrm{C}$ & 3.28836200 & -0.87511400 & -1.36359600 \\
$\mathrm{C}$ & -3.28824300 & -0.87528400 & -1.36354200 \\
$\mathrm{H}$ & -2.77527400 & -0.73866100 & -2.32951200 \\
$\mathrm{C}$ & -1.21609400 & 2.64623200 & -0.53865300 \\
$\mathrm{C}$ & 2.71300500 & 1.31775900 & 2.28426200 \\
$\mathrm{C}$ & -0.00002900 & -1.73282800 & 0.20157900 \\
$\mathrm{C}$ & -4.71241200 & -0.34335500 & -1.48353300
\end{tabular}




$\begin{array}{lrrr}\mathrm{H} & -4.75310000 & 0.71009900 & -1.77952900 \\ \mathrm{C} & 4.71250400 & -0.34312200 & -1.48348200 \\ \mathrm{C} & 2.60533000 & -1.17438800 & 2.23712100 \\ \mathrm{C} & -3.02683600 & 0.07152700 & 1.46366400 \\ \mathrm{H} & -4.11101900 & 0.03657100 & 1.27390200 \\ \mathrm{C} & -3.29321400 & -2.36203200 & -1.02890400 \\ \mathrm{C} & 3.29335300 & -2.36189000 & -1.02907700 \\ \mathrm{C} & 1.21604300 & 2.64627000 & -0.53852400 \\ \mathrm{C} & 2.45980500 & 1.84646200 & -0.85717200 \\ \mathrm{C} & -2.60530900 & -1.17415300 & 2.23716200 \\ \mathrm{C} & -2.45978700 & 1.84636800 & -0.85742100 \\ \mathrm{H} & 0.00005800 & 0.25634600 & 1.12219500 \\ \mathrm{H} & -2.28599600 & -2.77198400 & -0.89698500 \\ \mathrm{H} & -3.77833500 & -2.92001200 & -1.83831100 \\ \mathrm{H} & -3.86771600 & -2.55930600 & -0.11504600 \\ \mathrm{H} & -5.25637600 & -0.92000700 & -2.24148500 \\ \mathrm{H} & -5.26195700 & -0.45442000 & -0.54032700 \\ \mathrm{H} & -2.76696400 & -2.10560900 & 1.68510400 \\ \mathrm{H} & -2.58671100 & 1.76164800 & -1.94627600 \\ \mathrm{H} & -3.36117300 & 2.32978400 & -0.46253700 \\ \mathrm{H} & -1.21506700 & 3.61371800 & -1.05995200 \\ \mathrm{H} & -1.14528500 & 2.85041600 & 0.53664400 \\ \mathrm{H} & 1.21502200 & 3.61375800 & -1.05981900 \\ \mathrm{H} & 1.14510700 & 2.85044300 & 0.53676600 \\ \mathrm{H} & 2.58694100 & 1.76189200 & -1.94601200 \\ \mathrm{H} & 3.36111500 & 2.32982700 & -0.46205200 \\ \mathrm{H} & 3.08783600 & 2.23956800 & 1.82665200 \\ \mathrm{H} & 1.63048100 & 1.42053800 & 2.44510600 \\ \mathrm{H} & 3.18184100 & 1.23069800 & 3.27168100 \\ \mathrm{H} & 3.17477200 & -1.23702300 & 3.17195800 \\ \mathrm{H} & 4.11095100 & 0.03654800 & 1.27401600 \\ \mathrm{H} & 1.54037000 & -1.11998400 & 2.49856200 \\ \mathrm{H} & 2.76701600 & -2.10578000 & 1.68497000 \\ \mathrm{H} & 4.75316600 & 0.71035300 & -1.77941800 \\ \mathrm{H} & 5.26201500 & -0.45421500 & -0.54025900 \\ \mathrm{H} & 3.86788800 & -2.55922000 & -0.11525100 \\ \mathrm{H} & 5.25653300 & -0.91970200 & -2.24144400 \\ & 3.77845000 & -2.91982000 & -1.83853300 \\ \mathrm{H} & 2.28614000 & -2.77185500 & -0.89715200 \\ \mathrm{H} & -3.17477100 & -0.73843300 & -2.32957400 \\ \mathrm{H} & -1.23673300 & 3.17202600 \\ \mathrm{H} & & -1.11966400 & 2.49854600\end{array}$

\begin{tabular}{cccc}
$\left({ }^{\mathrm{iPr}} \mathrm{PN}^{\mathrm{H}} \mathrm{P}\right) \mathrm{Fe}(\mathrm{H})(\mathrm{CO})\left(\mathrm{PF}_{6}\right)(\mathbf{6})$ & \multicolumn{2}{c}{$\mathrm{G}_{\mathrm{THF}}=-1597757.482 \mathrm{kca}$} \\
$\mathrm{Fe}$ & 0.00021800 & -0.60452700 & 0.01639100 \\
$\mathrm{P}$ & -2.21162900 & -0.81812400 & -0.13828700 \\
$\mathrm{P}$ & 2.21218000 & -0.81712700 & -0.13820000 \\
$\mathrm{O}$ & -0.00041200 & -0.17390700 & 2.87107900 \\
$\mathrm{~N}$ & 0.00040300 & -0.98000500 & -2.02552000 \\
$\mathrm{H}$ & 0.00052700 & -0.01811200 & -2.37782700 \\
$\mathrm{C}$ & -2.99587600 & -2.32383500 & 0.63107300
\end{tabular}




\begin{tabular}{|c|c|c|c|}
\hline $\mathrm{C}$ & 2.69322100 & -3.59661000 & -0.14776800 \\
\hline $\mathrm{H}$ & 1.61052700 & -3.78278300 & -0.18640700 \\
\hline $\mathrm{H}$ & 3.15362600 & -4.45388100 & 0.35867500 \\
\hline $\mathrm{H}$ & 3.08096800 & -3.57607500 & -1.17208500 \\
\hline $\mathrm{C}$ & -3.34161100 & 0.60688700 & 0.25729100 \\
\hline $\mathrm{C}$ & 3.34179400 & 0.60834000 & 0.25662000 \\
\hline $\mathrm{H}$ & 2.80336500 & 1.45833100 & -0.18937000 \\
\hline $\mathrm{C}$ & 1.21421800 & -1.64334700 & -2.54835200 \\
\hline $\mathrm{C}$ & -2.69200400 & -3.59770500 & -0.14896200 \\
\hline $\mathrm{C}$ & -0.00004400 & -0.32938400 & 1.71613300 \\
\hline $\mathrm{C}$ & 4.72384500 & 0.48848600 & -0.37593900 \\
\hline $\mathrm{H}$ & 4.69097500 & 0.41907700 & -1.46810000 \\
\hline $\mathrm{C}$ & -4.72368200 & 0.48686400 & -0.37529600 \\
\hline $\mathrm{C}$ & -2.54569100 & -2.49289200 & 2.07919300 \\
\hline $\mathrm{C}$ & 2.99691100 & -2.32234200 & 0.63170100 \\
\hline $\mathrm{H}$ & 4.08380300 & -2.14458700 & 0.60525000 \\
\hline $\mathrm{C}$ & 3.45682400 & 0.85702800 & 1.75583500 \\
\hline $\mathrm{C}$ & -3.45676400 & 0.85504200 & 1.75656100 \\
\hline $\mathrm{C}$ & -1.21341200 & -1.64312700 & -2.54866900 \\
\hline $\mathrm{C}$ & -2.44480200 & -0.98530300 & -1.96827500 \\
\hline $\mathrm{C}$ & 2.54713400 & -2.49096300 & 2.07998500 \\
\hline $\mathrm{C}$ & 2.44551300 & -0.98523900 & -1.96808400 \\
\hline $\mathrm{H}$ & 0.00055700 & -2.06056600 & 0.28935800 \\
\hline $\mathrm{H}$ & 2.48091000 & 0.88909100 & 2.25063900 \\
\hline $\mathrm{H}$ & 3.94845400 & 1.82155900 & 1.93184100 \\
\hline $\mathrm{H}$ & 4.07225200 & 0.08659600 & 2.23874200 \\
\hline $\mathrm{H}$ & 5.32029800 & 1.37382400 & -0.12199800 \\
\hline $\mathrm{H}$ & 5.26986600 & -0.38519800 & 0.00381700 \\
\hline $\mathrm{H}$ & 2.72334500 & -1.60264700 & 2.69491600 \\
\hline $\mathrm{H}$ & 2.53738000 & 0.03981900 & -2.35782700 \\
\hline $\mathrm{H}$ & 3.36212000 & -1.52274400 & -2.23943700 \\
\hline $\mathrm{H}$ & 1.21989500 & -1.60767700 & -3.64780500 \\
\hline $\mathrm{H}$ & 1.15339500 & -2.69817700 & -2.25334900 \\
\hline $\mathrm{H}$ & -1.21896400 & -1.60712100 & -3.64810900 \\
\hline $\mathrm{H}$ & -1.15264000 & -2.69805200 & -2.25400300 \\
\hline $\mathrm{H}$ & -2.53675800 & 0.03992900 & -2.35751100 \\
\hline $\mathrm{H}$ & -3.36129800 & -1.52283500 & -2.23996800 \\
\hline $\mathrm{H}$ & -3.07992300 & -3.57686700 & -1.17320900 \\
\hline $\mathrm{H}$ & -1.60926300 & -3.78357400 & -0.18785500 \\
\hline $\mathrm{H}$ & -3.15206800 & -4.45532500 & 0.35720300 \\
\hline $\mathrm{H}$ & -3.08283900 & -3.33151100 & 2.53906700 \\
\hline $\mathrm{H}$ & -4.08280300 & -2.14633000 & 0.60493300 \\
\hline $\mathrm{H}$ & -1.47197400 & -2.71917500 & 2.11767800 \\
\hline $\mathrm{H}$ & -2.72149400 & -1.60469700 & 2.69441400 \\
\hline $\mathrm{H}$ & -4.69084600 & 0.41765900 & -1.46747100 \\
\hline $\mathrm{H}$ & -5.26955400 & -0.38696500 & 0.00432800 \\
\hline $\mathrm{H}$ & -4.07168000 & 0.08408300 & 2.23926500 \\
\hline $\mathrm{H}$ & -5.32030400 & 1.37204900 & -0.12121100 \\
\hline $\mathrm{H}$ & -3.94907400 & 1.81918500 & 1.93281000 \\
\hline $\mathrm{H}$ & -2.48086700 & 0.88766200 & 2.25134900 \\
\hline $\mathrm{H}$ & -2.80352400 & 1.45718600 & -0.18844600 \\
\hline
\end{tabular}




$\begin{array}{lrrr}\text { H } & 3.08428400 & -3.32955400 & 2.53992000 \\ \text { H } & 1.47339800 & -2.71708000 & 2.11886300 \\ \text { P } & -0.00089200 & 3.00656300 & -0.15761200 \\ \text { F } & -0.00075900 & 1.41820300 & -0.74158500 \\ \text { F } & -1.15098200 & 3.33121700 & -1.24543400 \\ \text { F } & -0.00099900 & 4.52469200 & 0.36835500 \\ \text { F } & 1.14741200 & 3.33191500 & -1.24703400 \\ \text { F } & 1.13593200 & 2.58698700 & 0.91401700 \\ \text { F } & -1.13589100 & 2.58625400 & 0.91567800\end{array}$

$\left({ }^{\mathrm{iPr} P N}{ }^{\mathrm{H}} \mathrm{P}\right) \mathrm{Fe}(\mathrm{H})(\mathrm{CO})\left(\mathrm{OCH}_{3}\right)(\mathbf{9}) \mathrm{G}_{\mathrm{THF}}=-1079816.289 \mathrm{kcal} / \mathrm{mol}$ $\begin{array}{llll}\mathrm{Fe} & -0.06006900 & -0.00418600 & 0.09045400\end{array}$

$\begin{array}{llll}\mathrm{H} & -0.07821500 & -1.45543700 & 0.55339000\end{array}$

$\mathrm{P} \quad 2.15217800 \quad-0.08141400 \quad-0.01214200$

$\mathrm{P} \quad-2.25433400 \quad-0.12548500 \quad-0.14722000$

$\begin{array}{llll}\mathrm{O} & -0.08040600 & 0.60335400 & 2.90447900\end{array}$

$\mathrm{N} \quad \begin{array}{llll}0.00948200 & -0.78403500 & -1.85063700\end{array}$

$\begin{array}{llll}\mathrm{H} & 0.02318200 & 0.04844900 & -2.44474000\end{array}$

$\begin{array}{lllll}\mathrm{C} & -0.08363300 & 0.39630600 & 1.75071900\end{array}$

$\begin{array}{llll}\mathrm{C} & 2.45400100 & -0.72303900 & -1.72850000\end{array}$

$\mathrm{H} \quad 2.54511700 \quad 0.14903100 \quad-2.39121500$

$\mathrm{H} \quad 3.38305600 \quad-1.29940600 \quad-1.82232000$

C $\quad 1.24430000 \quad-1.54348400 \quad-2.13320600$

$\mathrm{H} \quad 1.28820800 \quad-1.81773800 \quad-3.19913400$

$\mathrm{H} \quad \begin{array}{llll}\mathrm{H} & 1.18852600 & -2.47334200 & -1.55308900\end{array}$

C $\quad-1.18802700 \quad-1.56617300 \quad-2.22025700$

$\mathrm{H} \quad-1.14235200 \quad-2.50352000 \quad-1.65097900$

$\mathrm{H} \quad-1.15824300 \quad-1.82577100 \quad-3.29028300$

C $\quad-2.44370200 \quad-0.78840700 \quad-1.87624300$

$\mathrm{H} \quad-3.34125800 \quad-1.40882900 \quad-1.99426900$

$\begin{array}{llll}\mathrm{H} & -2.55215700 & 0.07285100 & -2.55089500\end{array}$

C $\quad 3.09426400 \quad-1.21840500 \quad 1.12945100$

$\begin{array}{llll}\mathrm{H} & 2.78179800 & -0.88455700 & 2.13279600\end{array}$

$\begin{array}{llll}\text { C } & 4.61280700 & -1.13393600 & 1.02432400\end{array}$

$\begin{array}{llll}\mathrm{H} & 4.95678000 & -1.33820700 & 0.00114400\end{array}$

$\mathrm{H} \quad 5.07267500 \quad-1.88814700 \quad 1.67588500$

$\begin{array}{llll}\mathrm{H} & 5.00687600 & -0.15831000 & 1.32458700\end{array}$

$\begin{array}{llll}\mathrm{C} & 2.64143700 & -2.66371200 & 0.94729900\end{array}$

$\mathrm{H} \quad \begin{array}{llll}\mathrm{H} & 1.55211500 & -2.76338800 & 1.00481300\end{array}$

$\mathrm{H} \quad 3.09047300 \quad-3.29536500 \quad 1.72361400$

$\begin{array}{llll}\mathrm{H} & 2.97452400 & -3.06019800 & -0.02202600\end{array}$

$\begin{array}{llll}\mathrm{C} & 2.96450000 & 1.58992000 & 0.04125400\end{array}$

$\begin{array}{llll}\mathrm{H} & 2.17299800 & 2.18233100 & -0.44445300\end{array}$

$\begin{array}{lllll}\mathrm{C} & 4.27342400 & 1.76966900 & -0.71789300\end{array}$

$\mathrm{H} \quad 5.10562700 \quad 1.22589500 \quad-0.25708700$

$\mathrm{H} \quad 4.54619700 \quad 2.83333100 \quad-0.72484300$

$\begin{array}{llll}\mathrm{H} & 4.20311400 & 1.44827800 & -1.76336300\end{array}$

$\begin{array}{llll}\text { C } & 3.06915500 & 2.08512500 & 1.48053900\end{array}$

$\mathrm{H} \quad 2.11464200 \quad 1.99624200 \quad 2.01290600$

$\mathrm{H} \quad 3.35918200 \quad 3.14329000 \quad 1.49173800$

$\begin{array}{llll}\mathrm{H} & 3.82819300 & 1.53650600 & 2.05360300\end{array}$ 


$\begin{array}{lrrr}\mathrm{C} & -3.30830600 & -1.29220300 & 0.85759700 \\ \mathrm{H} & -4.32835700 & -1.20056900 & 0.45213100 \\ \mathrm{C} & -2.85462600 & -2.73736900 & 0.69206100 \\ \mathrm{H} & -2.92259100 & -3.08594400 & -0.34508300 \\ \mathrm{H} & -3.48763100 & -3.39620300 & 1.29997400 \\ \mathrm{H} & -1.81622800 & -2.86079900 & 1.02617700 \\ \mathrm{C} & -3.31704300 & -0.90907000 & 2.33252600 \\ \mathrm{H} & -2.30153600 & -0.92781400 & 2.74831600 \\ \mathrm{H} & -3.92274500 & -1.62431100 & 2.90342400 \\ \mathrm{H} & -3.73399600 & 0.08851800 & 2.50921600 \\ \mathrm{C} & -3.20194600 & 1.47721800 & -0.22489000 \\ \mathrm{H} & -2.79058400 & 1.93065700 & -1.14022700 \\ \mathrm{C} & -4.70686900 & 1.31084000 & -0.38832800 \\ \mathrm{H} & -5.17134700 & 2.28360300 & -0.59466200 \\ \mathrm{H} & -5.17092600 & 0.92141300 & 0.52721900 \\ \mathrm{H} & -4.97088500 & 0.63645900 & -1.21293500 \\ \mathrm{C} & -2.83919800 & 2.40514100 & 0.92866100 \\ \mathrm{H} & -3.12218000 & 1.98972500 & 1.90430800 \\ \mathrm{H} & -3.36746800 & 3.36152200 & 0.81837500 \\ \mathrm{H} & -1.76043700 & 2.59146200 & 0.91431200 \\ \mathrm{O} & -0.06845900 & 1.92594000 & -0.59307300 \\ \mathrm{C} & -0.03667000 & 2.24223500 & -1.91336200 \\ \mathrm{H} & -0.09287400 & 3.33746400 & -2.08295600 \\ \mathrm{H} & 0.89645500 & 1.92659600 & -2.45655400 \\ \mathrm{H} & -0.88227800 & 1.82650900 & -2.52550200\end{array}$

$\begin{array}{lrrr}\left({ }^{\text {iPr}} \mathrm{PN}{ }^{\mathrm{H}} \mathrm{P}\right) \mathrm{Fe}(\mathrm{H})(\mathrm{CO})(\mathrm{OC}(\mathrm{H}) \mathrm{O})(\mathbf{1 0}) & \mathrm{G}_{\mathrm{THF}}=-1126319.208 \mathrm{kcal} / \mathrm{mol} \\ \mathrm{Fe} & 0.00122900 & 0.03524100 & -0.07237400 \\ \mathrm{C} & -0.02565100 & 0.85831100 & -1.57508700 \\ \mathrm{O} & -0.04846900 & 1.46733600 & -2.57482000 \\ \mathrm{~N} & 0.02326300 & -0.77184600 & 1.85523300 \\ \mathrm{C} & 1.21049100 & -0.42727700 & 2.65735200 \\ \mathrm{C} & 2.46934700 & -0.62925700 & 1.83671500 \\ \mathrm{P} & 2.20039000 & 0.15981800 & 0.17941200 \\ \mathrm{C} & 3.27533300 & -0.88412900 & -0.93301300 \\ \mathrm{C} & 4.76978300 & -0.73873400 & -0.67047900 \\ \mathrm{C} & 2.94313400 & -0.71515900 & -2.41116600 \\ \mathrm{C} & 3.04881900 & 1.81311500 & 0.32259300 \\ \mathrm{C} & 2.58035500 & 2.59459100 & 1.54501900 \\ \mathrm{C} & 2.85391900 & 2.65029300 & -0.93649400 \\ \mathrm{C} & -1.20760700 & -0.54744700 & 2.63250000 \\ \mathrm{C} & -2.41946200 & -0.86531600 & 1.78014400 \\ \mathrm{P} & -2.21338200 & 0.05795700 & 0.18845100 \\ \mathrm{C} & -3.42584200 & -0.75820000 & -0.96834100 \\ \mathrm{C} & -3.05030000 & -2.20939300 & -1.24945800 \\ \mathrm{C} & -3.53119600 & 0.00801800 & -2.28357300 \\ \mathrm{C} & -2.96910300 & 1.71442900 & 0.61685100 \\ \mathrm{C} & -4.48587400 & 1.68705800 & 0.77560000 \\ \mathrm{C} & -2.52952300 & 2.84245400 & -0.31089200 \\ \mathrm{H} & -1.19706600 & -1.15859100 & 3.54899500 \\ \mathrm{H} & 1.23727800 & -1.03656800 & 3.57496500\end{array}$




$\begin{array}{lrrr}\mathrm{H} & 1.10786200 & 0.62223400 & 2.96587700 \\ \mathrm{H} & 2.79942700 & 2.08089200 & 2.48806400 \\ \mathrm{H} & 3.09177600 & 3.56524600 & 1.57597400 \\ \mathrm{H} & 1.49992400 & 2.78633000 & 1.49854200 \\ \mathrm{H} & -0.05040400 & 1.38350100 & 0.59030300 \\ \mathrm{H} & 1.79434100 & 2.90533600 & -1.07091300 \\ \mathrm{H} & 3.41403200 & 3.59018900 & -0.85091700 \\ \mathrm{H} & 3.19501100 & 2.14376500 & -1.84651300 \\ \mathrm{H} & -1.21581800 & 0.50667100 & 2.94733900 \\ \mathrm{H} & -3.35435300 & -0.61053200 & 2.29543500 \\ \mathrm{H} & -2.44427500 & -1.93941600 & 1.55404900 \\ \mathrm{H} & 0.07821800 & -1.77821700 & 1.61709300 \\ \mathrm{H} & 2.63384800 & -1.70166700 & 1.66017400 \\ \mathrm{H} & 3.35577900 & -0.23901500 & 2.35323800 \\ \mathrm{H} & 4.11896900 & 1.58610200 & 0.44849100 \\ \mathrm{H} & 5.02602200 & -0.84051800 & 0.39157900 \\ \mathrm{H} & 5.14499200 & 0.23275100 & -1.01896800 \\ \mathrm{H} & 5.32115600 & -1.51292400 & -1.21949800 \\ \mathrm{H} & 3.52018600 & -1.43626700 & -3.00479400 \\ \mathrm{H} & 3.20126100 & 0.28557200 & -2.78039400 \\ \mathrm{H} & 1.87890900 & -0.89119400 & -2.59898800 \\ \mathrm{H} & 2.96437600 & -1.90001700 & -0.64143700 \\ \mathrm{H} & -2.10158700 & -2.26029900 & -1.79639400 \\ \mathrm{H} & -2.94466000 & -2.81334900 & -0.34063800 \\ \mathrm{H} & -3.82993200 & -2.67548900 & -1.86556600 \\ \mathrm{H} & -2.55329800 & 0.06623700 & -2.78055000 \\ \mathrm{H} & -4.21544000 & -0.51334400 & -2.96519000 \\ \mathrm{H} & -3.90845900 & 1.02879200 & -2.15815000 \\ \mathrm{H} & -4.39930300 & -0.73373000 & -0.45262500 \\ \mathrm{H} & -2.90320900 & 2.70477800 & -1.33339000 \\ \mathrm{H} & -2.52141700 & 1.91059200 & 1.60529800 \\ \mathrm{H} & -4.99150500 & 1.56789000 & -0.19126300 \\ \mathrm{H} & -4.83029900 & 2.63664100 & 1.20454700 \\ \mathrm{H} & -4.83224200 & 0.88421000 & 1.43763900 \\ \mathrm{H} & -2.92613500 & 3.79837500 & 0.05500700 \\ \mathrm{H} & -1.43756600 & 2.92117200 & -0.35813600 \\ \mathrm{O} & 0.15203900 & -1.87568700 & -0.94667400 \\ \mathrm{C} & 0.21957800 & -3.03680100 & -0.45586000 \\ \mathrm{H} & 0.27808600 & -3.85193700 & -1.21532700 \\ \mathrm{O} & 0.22622700 & -3.37083600 & 0.74895700\end{array}$


CO Bridging Dimers (Figure 8)

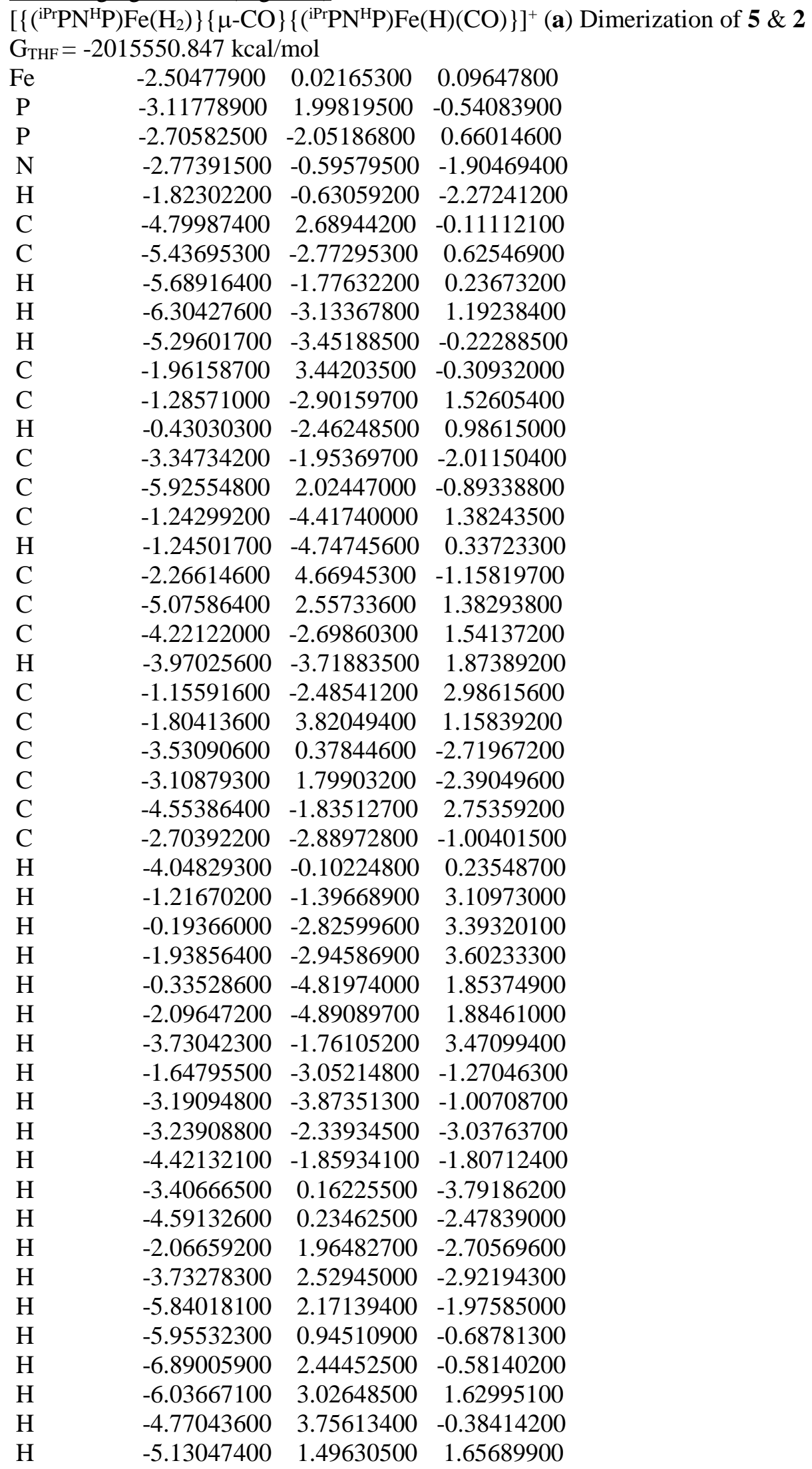




\begin{tabular}{|c|c|c|c|}
\hline $\mathrm{H}$ & -4.30508100 & 3.02011000 & 2.00797800 \\
\hline $\mathrm{H}$ & -2.30454300 & 4.44397500 & -2.22987900 \\
\hline $\mathrm{H}$ & -3.21892400 & 5.13413800 & -0.87381300 \\
\hline $\mathrm{H}$ & -2.70074500 & 4.32941800 & 1.53514400 \\
\hline $\mathrm{H}$ & -1.48744800 & 5.43060800 & -1.00820700 \\
\hline $\mathrm{H}$ & -0.96810900 & 4.52256400 & 1.28321100 \\
\hline $\mathrm{H}$ & -1.61497800 & 2.94287500 & 1.79065200 \\
\hline $\mathrm{H}$ & -1.01226400 & 3.00190500 & -0.65468100 \\
\hline $\mathrm{H}$ & -5.42345700 & -2.24767300 & 3.28059900 \\
\hline $\mathrm{H}$ & -4.79946400 & -0.81721900 & 2.42639200 \\
\hline $\mathrm{Fe}$ & 2.55599800 & 0.04687400 & -0.07030800 \\
\hline$P$ & 2.86955400 & 2.08148300 & 0.75184800 \\
\hline $\mathrm{P}$ & 2.64289400 & -2.12289100 & -0.53173800 \\
\hline $\mathrm{O}$ & 2.94608200 & 0.84131700 & -2.81874400 \\
\hline $\mathrm{N}$ & 2.44218800 & -0.56414600 & 1.91045700 \\
\hline $\mathrm{H}$ & 1.42693900 & -0.64465300 & 2.01989000 \\
\hline $\mathrm{C}$ & 4.57427200 & 2.82595800 & 0.70788800 \\
\hline $\mathrm{C}$ & 5.39950100 & -2.64958800 & -0.34795000 \\
\hline $\mathrm{H}$ & 5.60333900 & -1.58256500 & -0.18608100 \\
\hline $\mathrm{H}$ & 6.28725500 & -3.08974100 & -0.81812200 \\
\hline $\mathrm{H}$ & 5.27808000 & -3.13079100 & 0.62886300 \\
\hline $\mathrm{C}$ & 1.68039800 & 3.43125900 & 0.27152000 \\
\hline $\mathrm{C}$ & 1.21797700 & -2.89789900 & -1.45341200 \\
\hline $\mathrm{H}$ & 0.40904000 & -2.80625300 & -0.71185000 \\
\hline $\mathrm{C}$ & 3.03750400 & -1.89595900 & 2.16799500 \\
\hline $\mathrm{C}$ & 5.57730900 & 2.02258400 & 1.52800600 \\
\hline $\mathrm{C}$ & 2.75432000 & 0.52786000 & -1.71286700 \\
\hline $\mathrm{C}$ & 1.39782300 & -4.37476000 & -1.77854000 \\
\hline $\mathrm{H}$ & 1.68302400 & -4.96425000 & -0.89812900 \\
\hline $\mathrm{C}$ & 1.99524200 & 4.78326800 & 0.89916700 \\
\hline $\mathrm{C}$ & 5.06369900 & 2.96961500 & -0.72862400 \\
\hline $\mathrm{C}$ & 4.19477200 & -2.84716900 & -1.26048100 \\
\hline $\mathrm{H}$ & 3.99734700 & -3.92747800 & -1.34162100 \\
\hline $\mathrm{C}$ & 0.79771900 & -2.08514100 & -2.67292800 \\
\hline $\mathrm{C}$ & 1.47705900 & 3.54777800 & -1.23500200 \\
\hline $\mathrm{C}$ & 2.91493800 & 0.41491200 & 2.91973500 \\
\hline $\mathrm{C}$ & 2.48773100 & 1.82073600 & 2.54655000 \\
\hline $\mathrm{C}$ & 4.48233600 & -2.28009500 & -2.64489400 \\
\hline $\mathrm{C}$ & 2.54008300 & -2.90422200 & 1.15043000 \\
\hline $\mathrm{H}$ & 4.02866100 & -0.06519600 & -0.02714000 \\
\hline $\mathrm{H}$ & 0.59854400 & -1.03881400 & -2.40751900 \\
\hline $\mathrm{H}$ & -0.11409300 & -2.51489200 & -3.11202700 \\
\hline $\mathrm{H}$ & 1.56048200 & -2.08938500 & -3.46100200 \\
\hline $\mathrm{H}$ & 0.45607400 & -4.78835200 & -2.16275100 \\
\hline $\mathrm{H}$ & 2.15744500 & -4.52779200 & -2.55525800 \\
\hline $\mathrm{H}$ & 3.65287200 & -2.42079800 & -3.34698500 \\
\hline $\mathrm{H}$ & 1.48643100 & -3.15145800 & 1.34249400 \\
\hline $\mathrm{H}$ & 3.10366900 & -3.84315400 & 1.21134900 \\
\hline $\mathrm{H}$ & 2.81147000 & -2.22087500 & 3.19464400 \\
\hline $\mathrm{H}$ & 4.12542000 & -1.77075800 & 2.09289800 \\
\hline $\mathrm{H}$ & 2.54389200 & 0.13424500 & 3.91569000 \\
\hline
\end{tabular}




$\begin{array}{lrrr}\mathrm{H} & 4.00809300 & 0.33658100 & 2.94633200 \\ \mathrm{H} & 1.39868200 & 1.93255600 & 2.65709700 \\ \mathrm{H} & 2.96325200 & 2.56470500 & 3.19807700 \\ \mathrm{H} & 5.34373700 & 2.02020900 & 2.59822100 \\ \mathrm{H} & 5.63666900 & 0.98188700 & 1.17906300 \\ \mathrm{H} & 6.57474800 & 2.46489100 & 1.41621900 \\ \mathrm{H} & 6.05154000 & 3.44564400 & -0.73945600 \\ \mathrm{H} & 4.47785900 & 3.82325700 & 1.16346100 \\ \mathrm{H} & 5.16251800 & 1.98455400 & -1.20328900 \\ \mathrm{H} & 4.39851100 & 3.57979000 & -1.34929500 \\ \mathrm{H} & 2.14548900 & 4.72140500 & 1.98373100 \\ \mathrm{H} & 2.89249700 & 5.23173000 & 0.45370400 \\ \mathrm{H} & 2.39403500 & 3.84270700 & -1.75895800 \\ \mathrm{H} & 1.16638400 & 5.48051100 & 0.71741600 \\ \mathrm{H} & 0.72603900 & 4.32058900 & -1.44751800 \\ \mathrm{H} & 1.12478600 & 2.60678800 & -1.67370000 \\ \mathrm{H} & 0.74131800 & 3.04920300 & 0.70405000 \\ \mathrm{H} & 5.36284200 & -2.77415700 & -3.07284500 \\ \mathrm{H} & 4.69985800 & -1.20614900 & -2.58817000 \\ \mathrm{C} & -0.79759000 & 0.16825000 & 0.11835300 \\ \mathrm{O} & 0.39101900 & 0.23760300 & 0.16945500 \\ \mathrm{H} & -2.57732800 & 0.44382700 & 1.54293300\end{array}$

$\left[\left\{\left({ }^{\mathrm{iPr} P N}{ }^{\mathrm{H}} \mathrm{P}\right) \mathrm{Fe}(\mathrm{H})\left(\mathrm{OCH}_{3}\right)\right\}\{\mu-\mathrm{CO}\}\left\{\left({ }^{\mathrm{iPr}} \mathrm{PN}{ }^{\mathrm{H}} \mathrm{P}\right) \mathrm{Fe}(\mathrm{H})(\mathrm{CO})\right\}\right]^{+}(\mathbf{b})$ Dimerization of 5 \& 9 $\mathrm{G}_{\mathrm{THF}}=-2087366.374 \mathrm{kcal} / \mathrm{mol}$

$\begin{array}{lrrr}\mathrm{Fe} & -2.55289900 & -0.01311100 & -0.00813200 \\ \mathrm{H} & -2.46489700 & 0.82990300 & -1.27207100 \\ \mathrm{P} & -2.54119300 & 1.83946500 & 1.21180400 \\ \mathrm{P} & -2.97517000 & -1.75664600 & -1.31071500 \\ \mathrm{O} & 0.31473400 & -0.08666800 & -0.13337300 \\ \mathrm{~N} & -4.61995800 & 0.31507600 & -0.11730400 \\ \mathrm{H} & -4.98303500 & -0.21012700 & 0.68200800 \\ \mathrm{C} & -0.86739500 & -0.09070300 & -0.06370900 \\ \mathrm{C} & -4.33810100 & 2.27899800 & 1.31599100 \\ \mathrm{H} & -4.74764000 & 1.79090300 & 2.21104500 \\ \mathrm{H} & -4.51159300 & 3.35656300 & 1.42631100 \\ \mathrm{C} & -5.01308900 & 1.72670900 & 0.07627200 \\ \mathrm{H} & -6.10829000 & 1.80891400 & 0.14922100 \\ \mathrm{H} & -4.69807200 & 2.27344500 & -0.82130500 \\ \mathrm{C} & -5.25446300 & -0.24386000 & -1.32936700 \\ \mathrm{H} & -4.93108200 & 0.37720200 & -2.17429200 \\ \mathrm{H} & -6.34973800 & -0.16285700 & -1.25625900 \\ \mathrm{C} & -4.82008800 & -1.68314800 & -1.51568300 \\ \mathrm{H} & -5.15422300 & -2.08386800 & -2.48067500 \\ \mathrm{H} & -5.26102700 & -2.31496300 & -0.73150500 \\ \mathrm{C} & -1.68219800 & 3.35101200 & 0.54491900 \\ \mathrm{H} & -0.65348600 & 2.98935600 & 0.37939900 \\ \mathrm{C} & -1.64428000 & 4.54933400 & 1.48710400 \\ \mathrm{H} & -2.65492900 & 4.86263000 & 1.78168900 \\ \mathrm{H} & -1.17877300 & 5.40537400 & 0.98109500 \\ \mathrm{H} & -1.06996100 & 4.35789400 & 2.39851200\end{array}$




\begin{tabular}{|c|c|c|c|}
\hline $\mathrm{C}$ & -2.26390700 & 3.76714800 & -0.80240500 \\
\hline $\mathrm{H}$ & -2.31068200 & 2.93163000 & -1.51000600 \\
\hline $\mathrm{H}$ & -1.64884700 & 4.56260500 & -1.24412400 \\
\hline $\mathrm{H}$ & -3.27521700 & 4.17991400 & -0.68444400 \\
\hline $\mathrm{C}$ & -1.96436300 & 1.57433200 & 2.95545700 \\
\hline $\mathrm{H}$ & -2.29154300 & 0.53178200 & 3.09879900 \\
\hline $\mathrm{C}$ & -2.57871100 & 2.45699200 & 4.03506200 \\
\hline $\mathrm{H}$ & -2.27863800 & 3.50659400 & 3.94160100 \\
\hline $\mathrm{H}$ & -2.24397700 & 2.11005400 & 5.02119600 \\
\hline $\mathrm{H}$ & -3.67389700 & 2.42036500 & 4.03540900 \\
\hline $\mathrm{C}$ & -0.44019200 & 1.57881300 & 3.01072300 \\
\hline $\mathrm{H}$ & -0.00127500 & 0.87543300 & 2.29011700 \\
\hline $\mathrm{H}$ & -0.10257300 & 1.28102100 & 4.01159300 \\
\hline $\mathrm{H}$ & -0.01278400 & 2.57044900 & 2.80998800 \\
\hline $\mathrm{C}$ & -2.35029300 & -1.83820200 & -3.06659100 \\
\hline $\mathrm{H}$ & -2.70732000 & -2.79475400 & -3.47820400 \\
\hline $\mathrm{C}$ & -2.91381200 & -0.70406400 & -3.91470500 \\
\hline $\mathrm{H}$ & -4.00596600 & -0.73792500 & -3.99397600 \\
\hline $\mathrm{H}$ & -2.51135000 & -0.76858200 & -4.93314900 \\
\hline $\mathrm{H}$ & -2.62889500 & 0.27211200 & -3.50009800 \\
\hline $\mathrm{C}$ & -0.82724700 & -1.80498500 & -3.10898200 \\
\hline $\mathrm{H}$ & -0.46788500 & -0.86973700 & -2.65371600 \\
\hline $\mathrm{H}$ & -0.47136600 & -1.82752700 & -4.14697700 \\
\hline $\mathrm{H}$ & -0.36917000 & -2.65480900 & -2.58560000 \\
\hline $\mathrm{C}$ & -2.73913600 & -3.45020000 & -0.57811400 \\
\hline $\mathrm{H}$ & -3.41473100 & -3.39801000 & 0.28907600 \\
\hline $\mathrm{C}$ & -3.16611500 & -4.59152200 & -1.49120500 \\
\hline $\mathrm{H}$ & -3.16301800 & -5.53800000 & -0.93630600 \\
\hline $\mathrm{H}$ & -2.47087000 & -4.71047700 & -2.33282300 \\
\hline $\mathrm{H}$ & -4.17331200 & -4.45222600 & -1.90227300 \\
\hline $\mathrm{C}$ & -1.33281700 & -3.65859000 & -0.03504500 \\
\hline $\mathrm{H}$ & -0.59933900 & -3.75775700 & -0.84730900 \\
\hline $\mathrm{H}$ & -1.28809200 & -4.58923700 & 0.54612100 \\
\hline $\mathrm{H}$ & -1.04951800 & -2.82671300 & 0.62178600 \\
\hline $\mathrm{Fe}$ & 2.47847200 & -0.00709300 & -0.00859300 \\
\hline $\mathrm{H}$ & 3.95580700 & -0.06825700 & -0.07554600 \\
\hline $\mathrm{P}$ & 2.66573000 & 1.53459400 & -1.60061000 \\
\hline $\mathrm{P}$ & 2.67157000 & -1.81289600 & 1.28261900 \\
\hline $\mathrm{O}$ & 2.84186600 & 1.85542600 & 2.17010200 \\
\hline $\mathrm{N}$ & 2.34732700 & -1.35923700 & -1.57530800 \\
\hline $\mathrm{H}$ & 1.32855400 & -1.44180400 & -1.63890300 \\
\hline $\mathrm{C}$ & 2.66597300 & 1.10765500 & 1.29340100 \\
\hline $\mathrm{C}$ & 2.34948500 & 0.53930100 & -3.13075900 \\
\hline $\mathrm{H}$ & 1.25947900 & 0.54638600 & -3.28364500 \\
\hline $\mathrm{H}$ & 2.80456900 & 0.97392700 & -4.02893100 \\
\hline $\mathrm{C}$ & 2.83049300 & -0.87547300 & -2.88824900 \\
\hline $\mathrm{H}$ & 2.49353300 & -1.55558800 & -3.68537600 \\
\hline $\mathrm{H}$ & 3.92612300 & -0.91938300 & -2.86132300 \\
\hline $\mathrm{C}$ & 2.87381800 & -2.71369300 & -1.29520200 \\
\hline $\mathrm{H}$ & 3.96825300 & -2.64750200 & -1.32940400 \\
\hline $\mathrm{H}$ & 2.55872800 & -3.40903400 & -2.08867400 \\
\hline
\end{tabular}




$\begin{array}{lrrr}\mathrm{C} & 2.39091800 & -3.17519100 & 0.06204300 \\ \mathrm{H} & 2.84959600 & -4.12509000 & 0.36111500 \\ \mathrm{H} & 1.30341300 & -3.33312100 & 0.03227000 \\ \mathrm{C} & 4.32041600 & 2.35892300 & -1.83724200 \\ \mathrm{H} & 4.14295200 & 3.20420100 & -2.52098200 \\ \mathrm{C} & 5.34017400 & 1.42191300 & -2.47515900 \\ \mathrm{H} & 5.50822800 & 0.53741500 & -1.84432600 \\ \mathrm{H} & 6.30166100 & 1.94082400 & -2.57024800 \\ \mathrm{H} & 5.05025900 & 1.08799400 & -3.47715100 \\ \mathrm{C} & 4.87009100 & 2.88260500 & -0.51352700 \\ \mathrm{H} & 4.18282300 & 3.55415800 & 0.01061500 \\ \mathrm{H} & 5.80167400 & 3.43249200 & -0.69369400 \\ \mathrm{H} & 5.09898300 & 2.04565700 & 0.15909600 \\ \mathrm{C} & 1.39027200 & 2.88532000 & -1.73427600 \\ \mathrm{H} & 0.44815400 & 2.33514400 & -1.55900900 \\ \mathrm{C} & 1.32996200 & 3.54161800 & -3.10927900 \\ \mathrm{H} & 2.26514900 & 4.06482700 & -3.34679900 \\ \mathrm{H} & 0.52947000 & 4.29219500 & -3.12556900 \\ \mathrm{H} & 1.12609100 & 2.82792700 & -3.91392700 \\ \mathrm{C} & 1.55234500 & 3.93874800 & -0.64391000 \\ \mathrm{H} & 1.61381600 & 3.50667900 & 0.36379900 \\ \mathrm{H} & 0.69839400 & 4.62860000 & -0.66299600 \\ \mathrm{H} & 2.45069400 & 4.54618900 & -0.81186000 \\ \mathrm{C} & 4.31943700 & -2.16359300 & 2.08030300 \\ \mathrm{H} & 4.13407600 & -2.96839300 & 2.80962700 \\ \mathrm{C} & 5.35161900 & -2.64969100 & 1.06852900 \\ \mathrm{H} & 5.06962900 & -3.58910400 & 0.58143200 \\ \mathrm{H} & 6.30767000 & -2.82105300 & 1.57780700 \\ \mathrm{H} & 5.52697600 & -1.89054600 & 0.29307300 \\ \mathrm{H} & -4.70375300 & -1.92399300 & 1.62616600 \\ \mathrm{C} & & & \\ \mathrm{H} & 5.10236700 & -0.14495800 & 2.08192300 \\ \mathrm{H} & 5.78538800 & -1.19751400 & 3.33390600 \\ \mathrm{H} & 4.16409100 & -0.51769700 & 3.53774200 \\ \mathrm{C} & 1.38180300 & -2.15503300 & 2.58179500 \\ \mathrm{H} & 0.44871000 & -1.83686300 & 2.08440400 \\ \mathrm{C} & 1.26508500 & -3.62740400 & 2.96042300 \\ \mathrm{H} & 0.48210400 & -3.75017200 & 3.71914800 \\ \mathrm{H} & 2.19925600 & -4.00631400 & 3.39549300 \\ \mathrm{H} & 1.00215400 & -4.26796400 & 2.11207600 \\ \mathrm{H} & 1.58106000 & -1.29617000 & 3.82568700 \\ \mathrm{H} & 2.43165500 & -1.65408600 & 4.41993800 \\ \mathrm{H} & 1.74749500 & -0.23894300 & 3.58878000 \\ \mathrm{H} & -3.82851700 & -1.18915000 & 1.64964400 \\ \mathrm{H} & & -435600 & 2.26489200 \\ \mathrm{H} & -2.09724200 & 3.13720600 \\ \mathrm{H} & & & \end{array}$

$\left[\left\{\left({ }^{\left({ }^{\mathrm{Pr}} \mathrm{PN}\right.}{ }^{\mathrm{H}} \mathrm{P}\right) \mathrm{Fe}(\mathrm{H})(\mathrm{OC}(\mathrm{H}) \mathrm{O})\right\}\{\mu-\mathrm{CO}\}\left\{\left({ }^{\mathrm{iPr} P N}{ }^{\mathrm{H}} \mathrm{P}\right) \mathrm{Fe}(\mathrm{H})(\mathrm{CO})\right\}\right]^{+}(\mathbf{c})$ Dimerization of 5 \& 10 $\mathrm{G}_{\mathrm{THF}}=-2133849.942 \mathrm{kcal} / \mathrm{mol}$ 


\begin{tabular}{|c|c|c|c|}
\hline $\mathrm{Fe}$ & -2.46099200 & 0.08214500 & -0.04972900 \\
\hline $\mathrm{H}$ & -2.30983800 & 0.94588000 & -1.26184200 \\
\hline $\mathrm{P}$ & -2.41340000 & 1.90865000 & 1.22310900 \\
\hline $\mathrm{P}$ & -2.94463500 & -1.55378800 & -1.48905800 \\
\hline $\mathrm{O}$ & 0.40721700 & -0.05719300 & -0.16981200 \\
\hline $\mathrm{O}$ & -2.69202300 & -1.09243200 & 1.66098500 \\
\hline $\mathrm{O}$ & -4.88927400 & -1.61869900 & 1.66446300 \\
\hline $\mathrm{N}$ & -4.51200700 & 0.47247600 & -0.17924200 \\
\hline $\mathrm{H}$ & -4.84539800 & -0.20681000 & 0.52838400 \\
\hline $\mathrm{C}$ & -0.77260700 & -0.04537100 & -0.09591900 \\
\hline $\mathrm{C}$ & -3.72939800 & -1.66292900 & 2.11174900 \\
\hline $\mathrm{H}$ & -3.54461600 & -2.27800300 & 3.02454800 \\
\hline $\mathrm{C}$ & -4.20960800 & 2.25757400 & 1.46864100 \\
\hline $\mathrm{H}$ & -4.53244900 & 1.63268600 & 2.31433600 \\
\hline $\mathrm{H}$ & -4.41885600 & 3.30283800 & 1.72840300 \\
\hline $\mathrm{C}$ & -4.93335600 & 1.82942600 & 0.20925000 \\
\hline $\mathrm{H}$ & -6.02445300 & 1.86095300 & 0.35036800 \\
\hline $\mathrm{H}$ & -4.69485400 & 2.50188500 & -0.62543200 \\
\hline $\mathrm{C}$ & -5.11610600 & 0.09928400 & -1.47047100 \\
\hline $\mathrm{H}$ & -4.72492800 & 0.79027000 & -2.23012900 \\
\hline $\mathrm{H}$ & -6.20835300 & 0.23369600 & -1.43111000 \\
\hline $\mathrm{C}$ & -4.75967700 & -1.33573500 & -1.79804900 \\
\hline $\mathrm{H}$ & -5.04442400 & -1.60441600 & -2.82230200 \\
\hline $\mathrm{H}$ & -5.28599700 & -2.01480900 & -1.11492200 \\
\hline $\mathrm{C}$ & -1.62743300 & 3.43392700 & 0.50286000 \\
\hline $\mathrm{H}$ & -0.60120200 & 3.08458100 & 0.30240400 \\
\hline $\mathrm{C}$ & -1.57029600 & 4.64582000 & 1.42707700 \\
\hline $\mathrm{H}$ & -2.57104900 & 4.93319300 & 1.77630900 \\
\hline $\mathrm{H}$ & -1.16189000 & 5.50673100 & 0.88166900 \\
\hline $\mathrm{H}$ & -0.93631300 & 4.48637100 & 2.30454900 \\
\hline $\mathrm{C}$ & -2.26014600 & 3.83105800 & -0.82758600 \\
\hline $\mathrm{H}$ & -2.36247700 & 2.98277400 & -1.51415000 \\
\hline $\mathrm{H}$ & -1.63994600 & 4.59468200 & -1.31574000 \\
\hline $\mathrm{H}$ & -3.25218300 & 4.27650200 & -0.67208100 \\
\hline $\mathrm{C}$ & -1.72517100 & 1.67162300 & 2.93276200 \\
\hline $\mathrm{H}$ & -2.03741900 & 0.63526100 & 3.13516500 \\
\hline $\mathrm{C}$ & -2.29230200 & 2.57067700 & 4.02661600 \\
\hline $\mathrm{H}$ & -2.00076200 & 3.61866000 & 3.90150600 \\
\hline $\mathrm{H}$ & -1.90679900 & 2.24017000 & 4.99944500 \\
\hline $\mathrm{H}$ & -3.38547400 & 2.52995900 & 4.08036400 \\
\hline $\mathrm{C}$ & -0.20211600 & 1.70386000 & 2.90314100 \\
\hline $\mathrm{H}$ & 0.21188500 & 0.99794900 & 2.17118400 \\
\hline $\mathrm{H}$ & 0.19915100 & 1.43442000 & 3.88818400 \\
\hline $\mathrm{H}$ & 0.18948700 & 2.70083700 & 2.66086400 \\
\hline $\mathrm{C}$ & -2.21160800 & -1.54528700 & -3.20276300 \\
\hline $\mathrm{H}$ & -2.61924500 & -2.43383800 & -3.70853800 \\
\hline $\mathrm{C}$ & -2.62766500 & -0.30695300 & -3.98792800 \\
\hline $\mathrm{H}$ & -3.71184400 & -0.23950800 & -4.12892200 \\
\hline $\mathrm{H}$ & -2.16976900 & -0.33139300 & -4.98443600 \\
\hline $\mathrm{H}$ & -2.28918700 & 0.60882800 & -3.48444300 \\
\hline $\mathrm{C}$ & -0.69209000 & -1.64013700 & -3.15737200 \\
\hline
\end{tabular}




\begin{tabular}{|c|c|c|c|}
\hline $\mathrm{H}$ & -0.28928800 & -0.73965900 & -2.67072300 \\
\hline $\mathrm{H}$ & -0.27836700 & -1.68196400 & -4.17301900 \\
\hline $\mathrm{H}$ & -0.33620100 & -2.52815000 & -2.61719700 \\
\hline $\mathrm{C}$ & -2.87245500 & -3.31382900 & -0.88059300 \\
\hline $\mathrm{H}$ & -3.64542500 & -3.29436400 & -0.09634700 \\
\hline $\mathrm{C}$ & -3.25826600 & -4.35028800 & -1.92788300 \\
\hline $\mathrm{H}$ & -3.36242900 & -5.33593100 & -1.45781900 \\
\hline $\mathrm{H}$ & -2.48563200 & -4.44250000 & -2.70243800 \\
\hline $\mathrm{H}$ & -4.20911900 & -4.11733500 & -2.42204200 \\
\hline $\mathrm{C}$ & -1.54659200 & -3.65346100 & -0.21376400 \\
\hline $\mathrm{H}$ & -0.74239600 & -3.75524500 & -0.95569000 \\
\hline $\mathrm{H}$ & -1.62189200 & -4.61743100 & 0.30581000 \\
\hline $\mathrm{H}$ & -1.26656400 & -2.88775500 & 0.52108200 \\
\hline $\mathrm{Fe}$ & 2.56879500 & -0.08123900 & 0.02192700 \\
\hline $\mathrm{H}$ & 4.04345100 & -0.21670200 & 0.00310600 \\
\hline $\mathrm{P}$ & 2.86152600 & 1.53651100 & -1.48112900 \\
\hline $\mathrm{P}$ & 2.57625000 & -1.96197500 & 1.22196200 \\
\hline $\mathrm{O}$ & 2.99880900 & 1.63681200 & 2.30404400 \\
\hline $\mathrm{N}$ & 2.44394800 & -1.33890200 & -1.62124500 \\
\hline $\mathrm{H}$ & 1.42820200 & -1.37123900 & -1.74300400 \\
\hline $\mathrm{C}$ & 2.78949100 & 0.94965500 & 1.38616800 \\
\hline $\mathrm{C}$ & 2.58624300 & 0.63041600 & -3.07326900 \\
\hline $\mathrm{H}$ & 1.50581300 & 0.67885900 & -3.27741100 \\
\hline $\mathrm{H}$ & 3.09611300 & 1.09507900 & -3.92560300 \\
\hline $\mathrm{C}$ & 3.01436800 & -0.80890100 & -2.88021700 \\
\hline $\mathrm{H}$ & 2.70013600 & -1.43692800 & -3.72765300 \\
\hline $\mathrm{H}$ & 4.10519200 & -0.88919300 & -2.79746100 \\
\hline $\mathrm{C}$ & 2.89047000 & -2.72968300 & -1.38629400 \\
\hline $\mathrm{H}$ & 3.98648400 & -2.71484600 & -1.34423900 \\
\hline $\mathrm{H}$ & 2.59833100 & -3.36611100 & -2.23570000 \\
\hline $\mathrm{C}$ & 2.29349800 & -3.23519500 & -0.09130800 \\
\hline $\mathrm{H}$ & 2.67239500 & -4.22791900 & 0.17897600 \\
\hline $\mathrm{H}$ & 1.20214700 & -3.32075600 & -0.19851100 \\
\hline $\mathrm{C}$ & 4.53804900 & 2.33880700 & -1.61755700 \\
\hline $\mathrm{H}$ & 4.39957100 & 3.22252300 & -2.26037100 \\
\hline $\mathrm{C}$ & 5.55973500 & 1.41489200 & -2.27156900 \\
\hline $\mathrm{H}$ & 5.69107500 & 0.49667600 & -1.68213900 \\
\hline $\mathrm{H}$ & 6.53309900 & 1.91856300 & -2.31003400 \\
\hline $\mathrm{H}$ & 5.29606000 & 1.13778900 & -3.29777100 \\
\hline $\mathrm{C}$ & 5.05402600 & 2.77879000 & -0.25057200 \\
\hline $\mathrm{H}$ & 4.36386100 & 3.43662000 & 0.28720400 \\
\hline $\mathrm{H}$ & 6.00196500 & 3.31681000 & -0.37129400 \\
\hline $\mathrm{H}$ & 5.24443900 & 1.90247600 & 0.38291700 \\
\hline $\mathrm{C}$ & 1.61062900 & 2.91390700 & -1.58524300 \\
\hline $\mathrm{H}$ & 0.65356900 & 2.36786200 & -1.49327300 \\
\hline $\mathrm{C}$ & 1.62221200 & 3.66141000 & -2.91389700 \\
\hline $\mathrm{H}$ & 2.56670700 & 4.19949700 & -3.06508000 \\
\hline $\mathrm{H}$ & 0.82008700 & 4.41058600 & -2.92046900 \\
\hline $\mathrm{H}$ & 1.46400600 & 3.00350100 & -3.77452500 \\
\hline $\mathrm{C}$ & 1.73527400 & 3.88817300 & -0.41923900 \\
\hline $\mathrm{H}$ & 1.73227100 & 3.38588900 & 0.55749900 \\
\hline
\end{tabular}




$\begin{array}{llrl}\mathrm{H} & 0.89997800 & 4.60091500 & -0.43547200 \\ \mathrm{H} & 2.65528600 & 4.48115300 & -0.49669900 \\ \mathrm{C} & 4.13079000 & -2.47235800 & 2.11222900 \\ \mathrm{H} & 3.83762100 & -3.30643000 & 2.76998500 \\ \mathrm{C} & 5.20378200 & -2.96442900 & 1.14706700 \\ \mathrm{H} & 4.89668000 & -3.84521100 & 0.57331200 \\ \mathrm{H} & 6.10233000 & -3.24053100 & 1.71184600 \\ \mathrm{H} & 5.49174400 & -2.17056100 & 0.44388200 \\ \mathrm{C} & 4.68952500 & -1.33019100 & 2.95527700 \\ \mathrm{H} & 5.01635600 & -0.50522900 & 2.30849000 \\ \mathrm{H} & 5.56398900 & -1.68097100 & 3.51649500 \\ \mathrm{H} & 3.97057200 & -0.92829300 & 3.67593800 \\ \mathrm{C} & 1.16914700 & -2.26911100 & 2.40286000 \\ \mathrm{H} & 0.30166900 & -1.86649200 & 1.85177500 \\ \mathrm{C} & 0.92427200 & -3.74324800 & 2.70486900 \\ \mathrm{H} & 0.05426200 & -3.84166200 & 3.36664400 \\ \mathrm{H} & 1.78005200 & -4.19337100 & 3.22484300 \\ \mathrm{H} & 0.72206100 & -4.33856300 & 1.80820400 \\ \mathrm{C} & 1.32057300 & -1.47689800 & 3.69679700 \\ \mathrm{H} & 2.07273500 & -1.93414800 & 4.35248300 \\ \mathrm{H} & 0.36903000 & -1.47579600 & 4.24374500 \\ \mathrm{H} & 1.60561500 & -0.43310500 & 3.52443900\end{array}$




\begin{tabular}{|c|c|c|c|}
\hline \multicolumn{3}{|c|}{$\frac{\text { CO Loss (Table 1) }}{\left({ }^{\mathrm{PP}} \mathrm{PN}^{\mathrm{H}} \mathrm{P}\right) \mathrm{Fe}(\mathrm{H})_{2}(2 \text { no CO singlet })}$} & \multirow{2}{*}{$\begin{array}{l}\mathrm{G}_{\mathrm{THF}}=-936878.373 \mathrm{kcal} / \mathrm{mol} \\
0.04268600\end{array}$} \\
\hline $\mathrm{Fe}$ & -0.00015100 & 0.14073000 & \\
\hline $\mathrm{H}$ & -0.00044100 & -1.00742100 & 1.16336600 \\
\hline $\mathrm{P}$ & 2.20266200 & 0.06564700 & -0.09756000 \\
\hline $\mathrm{P}$ & -2.20294000 & 0.06499600 & -0.09723700 \\
\hline $\mathrm{N}$ & -0.00022800 & -1.17523700 & -1.51426400 \\
\hline $\mathrm{H}$ & -0.00150200 & -0.53365100 & -2.30913900 \\
\hline $\mathrm{C}$ & 2.44058700 & -1.10085800 & -1.53049700 \\
\hline $\mathrm{H}$ & 2.51287600 & -0.49363000 & -2.44470200 \\
\hline $\mathrm{H}$ & 3.36452000 & -1.68782400 & -1.45394700 \\
\hline $\mathrm{C}$ & 1.21934200 & -1.99793200 & -1.60146900 \\
\hline $\mathrm{H}$ & 1.21053000 & -2.59738800 & -2.52601300 \\
\hline $\mathrm{H}$ & 1.19336600 & -2.69259000 & -0.75138800 \\
\hline $\mathrm{C}$ & -1.21867400 & -1.99985500 & -1.59889900 \\
\hline $\mathrm{H}$ & -1.19067100 & -2.69308600 & -0.74771300 \\
\hline $\mathrm{H}$ & -1.21009100 & -2.60067200 & -2.52257000 \\
\hline $\mathrm{C}$ & -2.44103900 & -1.10432700 & -1.52791300 \\
\hline $\mathrm{H}$ & -3.36411500 & -1.69234300 & -1.44919800 \\
\hline $\mathrm{H}$ & -2.51530500 & -0.49882200 & -2.44310400 \\
\hline $\mathrm{C}$ & 3.32977800 & -0.66698100 & 1.20780200 \\
\hline $\mathrm{H}$ & 4.35134100 & -0.63831400 & 0.79738200 \\
\hline $\mathrm{C}$ & 2.96933300 & -2.11721500 & 1.50161900 \\
\hline $\mathrm{H}$ & 1.92739500 & -2.19515300 & 1.83777500 \\
\hline $\mathrm{H}$ & 3.61752500 & -2.51161000 & 2.29504400 \\
\hline $\mathrm{H}$ & 3.09274100 & -2.76587900 & 0.62597500 \\
\hline $\mathrm{C}$ & 3.27575600 & 0.16069400 & 2.48662700 \\
\hline $\mathrm{H}$ & 3.67389500 & 1.17243100 & 2.35132400 \\
\hline $\mathrm{H}$ & 3.86184400 & -0.31912200 & 3.28115000 \\
\hline $\mathrm{H}$ & 2.24129300 & 0.25080700 & 2.84698300 \\
\hline $\mathrm{C}$ & 3.12134300 & 1.58342900 & -0.69623400 \\
\hline $\mathrm{H}$ & 2.66466900 & 1.72065300 & -1.68985500 \\
\hline $\mathrm{C}$ & 4.62524800 & 1.41880900 & -0.86413400 \\
\hline $\mathrm{H}$ & 5.13146700 & 1.33932300 & 0.10690700 \\
\hline $\mathrm{H}$ & 5.04913900 & 2.29298100 & -1.37540300 \\
\hline $\mathrm{H}$ & 4.88654900 & 0.53093500 & -1.45353400 \\
\hline $\mathrm{C}$ & 2.77918000 & 2.81696300 & 0.13088800 \\
\hline $\mathrm{H}$ & 1.69437100 & 2.91656200 & 0.25992300 \\
\hline $\mathrm{H}$ & 3.14951600 & 3.72419900 & -0.36375000 \\
\hline $\mathrm{H}$ & 3.24051100 & 2.78258600 & 1.12572000 \\
\hline $\mathrm{C}$ & -3.32911300 & -0.66543900 & 1.21010200 \\
\hline $\mathrm{H}$ & -4.35094000 & -0.63790100 & 0.80027600 \\
\hline $\mathrm{C}$ & -2.96788000 & -2.11495500 & 1.50648400 \\
\hline $\mathrm{H}$ & -3.09152900 & -2.76533800 & 0.63214400 \\
\hline $\mathrm{H}$ & -3.61540900 & -2.50811100 & 2.30106800 \\
\hline $\mathrm{H}$ & -1.92565300 & -2.19167700 & 1.84202400 \\
\hline $\mathrm{C}$ & -3.27449900 & 0.16472600 & 2.48729100 \\
\hline $\mathrm{H}$ & -2.23985300 & 0.25557500 & 2.84692900 \\
\hline $\mathrm{H}$ & -3.86014900 & -0.31358000 & 3.28304200 \\
\hline $\mathrm{H}$ & -3.67274000 & 1.17619100 & 2.35023800 \\
\hline $\mathrm{C}$ & -3.12234000 & 1.58126000 & -0.69865200 \\
\hline
\end{tabular}




$\begin{array}{lrrr}\mathrm{H} & -2.66650600 & 1.71629700 & -1.69296100 \\ \mathrm{C} & -4.62635400 & 1.41600600 & -0.86493500 \\ \mathrm{H} & -5.05081600 & 2.28892400 & -1.37786500 \\ \mathrm{H} & -5.13173300 & 1.33868400 & 0.10672000 \\ \mathrm{H} & -4.88801300 & 0.52672800 & -1.45205400 \\ \mathrm{C} & -2.77957100 & 2.81666600 & 0.12536800 \\ \mathrm{H} & -3.23938100 & 2.78417200 & 1.12097600 \\ \mathrm{H} & -3.15100000 & 3.72271900 & -0.37062200 \\ \mathrm{H} & -1.69458600 & 2.91678500 & 0.25246900 \\ \mathrm{H} & 0.00000000 & 1.34964300 & -1.03236000\end{array}$

$\left[\left({ }^{\mathrm{iPr}} \mathrm{PN}{ }^{\mathrm{H}} \mathrm{P}\right) \mathrm{Fe}(\mathrm{H})(\mathrm{THF})\right]^{+}($5-THF no CO singlet $) \mathrm{G}_{\mathrm{THF}}=-1082146.556 \mathrm{kcal} / \mathrm{mol}$ Fe $\quad-0.05185400 \quad-0.23135100 \quad-0.07804800$

$\begin{array}{llll}\mathrm{P} & 2.16795000 & -0.56719500 & 0.01004700\end{array}$

$\begin{array}{llll}\mathrm{P} & -2.29090900 & -0.30028600 & 0.01465300\end{array}$

$\mathrm{N} \quad-0.06997400 \quad-0.66014300 \quad 1.90727600$

$\mathrm{H} \quad 0.03977100 \quad 0.23434600 \quad 2.39346800$

C $\quad 2.86939500 \quad-2.00424700 \quad-0.95290200$

C $\quad-3.05338400 \quad-3.01298200 \quad-0.05846400$

$\mathrm{H} \quad-1.99338400 \quad-3.29959000 \quad-0.02152400$

$\mathrm{H} \quad-3.59026500-3.80805000 \quad-0.59049400$

$\mathrm{H} \quad-3.44312600 \quad-2.98449300 \quad 0.96515400$

C $\quad 3.42844600 \quad 0.79879200 \quad-0.20507100$

$\begin{array}{lllll}\mathrm{C} & -3.28613600 & 1.23837200 & -0.33795500\end{array}$

$\mathrm{H} \quad-2.68470200 \quad 2.01648000 \quad 0.16322400$

$\begin{array}{llll}\mathrm{C} & -1.34227500 & -1.25467000 & 2.38967900\end{array}$

$\begin{array}{llll}\text { C } & 2.52057700 & -3.34855700 & -0.32657300\end{array}$

$\begin{array}{llll}\text { C } & -4.68869000 & 1.23697500 & 0.25725800\end{array}$

$\begin{array}{llll}\mathrm{H} & -4.68793100 & 1.10851600 & 1.34486000\end{array}$

$\begin{array}{llll}\mathrm{C} & 4.80997700 & 0.47858800 & 0.35340500\end{array}$

$\begin{array}{llll}\mathrm{C} & 2.35139900 & -1.95019800 & -2.38815600\end{array}$

$\begin{array}{llll}\text { C } & -3.22783600 & -1.69253500 & -0.79907200\end{array}$

$\mathrm{H} \quad-4.29388900 \quad-1.41613900 \quad-0.78357500$

$\begin{array}{llll}\text { C } & -3.33318300 & 1.55030300 & -1.82997800\end{array}$

C $\quad 3.52971100 \quad 1.26299400 \quad-1.65335600$

$\begin{array}{llll}\mathrm{C} & 1.06427800 & -1.52167000 & 2.32596600\end{array}$

$\begin{array}{llll}\text { C } & 2.37397600 & -0.96484100 & 1.81022600\end{array}$

$\begin{array}{llll}\text { C } & -2.76086800 & -1.84953800 & -2.24404100\end{array}$

$\begin{array}{llll}\text { C } & -2.52729100 & -0.48831000 & 1.84269600\end{array}$

$\mathrm{H} \quad-0.11446900-1.72033200 \quad-0.38051600$

$\begin{array}{lllll}\mathrm{H} & -2.34981700 & 1.46125200 & -2.31039400\end{array}$

$\mathrm{H} \quad-3.69780300 \quad 2.57193700 \quad-1.99401400$

$\mathrm{H} \quad-4.02373400 \quad 0.87449600 \quad-2.35111900$

$\mathrm{H} \quad-5.18914200 \quad 2.18884100 \quad 0.03832300$

$\mathrm{H} \quad-5.30841100 \quad 0.44176500 \quad-0.17704400$

$\mathrm{H} \quad-2.88705400 \quad-0.93855500 \quad-2.83837500$

$\mathrm{H} \quad-2.54613700 \quad 0.52880800 \quad 2.26275600$

$\mathrm{H} \quad-3.47442200 \quad-0.96952000 \quad 2.11565500$

$\mathrm{H} \quad-1.34628200 \quad-1.27981500 \quad 3.48913500$

$\mathrm{H} \quad-1.35752900 \quad-2.29251900 \quad 2.03601500$

$\mathrm{H} \quad 1.07181400 \quad-1.62049800 \quad 3.42158300$ 


$\begin{array}{lrrr}\mathrm{H} & 0.87249400 & -2.51483200 & 1.90233700 \\ \mathrm{H} & 2.60989000 & -0.02004800 & 2.32205400 \\ \mathrm{H} & 3.20405000 & -1.65291600 & 2.01029900 \\ \mathrm{H} & 2.93915600 & -3.47311600 & 0.67834800 \\ \mathrm{H} & 1.43143800 & -3.47830500 & -0.26943300 \\ \mathrm{H} & 2.91832700 & -4.15968600 & -0.94902500 \\ \mathrm{H} & 2.78502600 & -2.76663600 & -2.97894100 \\ \mathrm{H} & 3.96433700 & -1.88851600 & -0.95335900 \\ \mathrm{H} & 1.25940900 & -2.06913900 & -2.39637000 \\ \mathrm{H} & 2.59092000 & -1.00905100 & -2.89542100 \\ \mathrm{H} & 4.78884800 & 0.21838700 & 1.41684300 \\ \mathrm{H} & 5.27976700 & -0.35188300 & -0.18881400 \\ \mathrm{H} & 4.05147500 & 0.51992200 & -2.27006400 \\ \mathrm{H} & 5.46911000 & 1.34854800 & 0.24005400 \\ \mathrm{H} & 4.10799500 & 2.19343300 & -1.71472500 \\ \mathrm{H} & 2.54740500 & 1.44604200 & -2.10838500 \\ \mathrm{H} & 2.99168500 & 1.61910000 & 0.39069700 \\ \mathrm{H} & -3.32463400 & -2.65043900 & -2.73832200 \\ \mathrm{H} & -1.69691600 & -2.12153500 & -2.26542500 \\ \mathrm{O} & -0.04318300 & 1.89209800 & 0.15225500 \\ \mathrm{C} & 0.05004900 & 2.71127900 & -1.02611800 \\ \mathrm{C} & 0.33177500 & 2.64823600 & 1.31326500 \\ \mathrm{C} & 0.93143100 & 3.87253800 & -0.62132600 \\ \mathrm{H} & 0.44898700 & 2.08927700 & -1.83892600 \\ \mathrm{H} & -0.95980900 & 3.04842200 & -1.30635700 \\ \mathrm{C} & 0.50208500 & 4.07740600 & 0.82834800 \\ \mathrm{H} & -0.45195600 & 2.53660400 & 2.07432800 \\ \mathrm{H} & 1.27494300 & 2.23879200 & 1.71006300 \\ \mathrm{H} & 0.78004800 & 4.75389800 & -1.24980200 \\ \mathrm{H} & 1.99104800 & 3.58693300 & -0.67618100 \\ \mathrm{H} & -0.45656400 & 4.60932600 & 0.86720100 \\ \mathrm{H} & 1.22728800 & 4.63445900 & 1.42701100\end{array}$

$\left({ }^{\mathrm{iPr} P N}{ }^{\mathrm{H}} \mathrm{P}\right) \mathrm{Fe}(\mathrm{H})\left(\mathrm{PF}_{6}\right)(6$ no CO singlet $) \mathrm{G}_{\mathrm{THF}}=-1526641.891 \mathrm{kcal} / \mathrm{mol}$

$\begin{array}{lllll}\mathrm{Fe} & 0.00604500 & -0.33442500 & -0.16630100\end{array}$

$\begin{array}{llll}\mathrm{P} & -2.21895200 & -0.71672700 & -0.08708100\end{array}$

$\begin{array}{llll}\mathrm{P} & 2.22972100 & -0.68765700 & -0.09137100\end{array}$

$\begin{array}{llll}\mathrm{N} & 0.01120100 & -1.46059300 & -1.85385800\end{array}$

$\begin{array}{llll}\mathrm{H} & -0.04268500 & -0.73831500 & -2.57922000\end{array}$

$\begin{array}{llll}\text { C } & -2.80787300 & -1.87329600 & 1.26280600\end{array}$

$\begin{array}{llll}\mathrm{C} & 2.48114800 & -3.35518600 & 0.86604600\end{array}$

$\begin{array}{llll}\mathrm{H} & 1.39113600 & -3.47993600 & 0.80337800\end{array}$

$\mathrm{H} \quad 2.84081900-4.01284900 \quad 1.66781100$

$\begin{array}{llll}\mathrm{H} & 2.92861700 & -3.70795500 & -0.07021400\end{array}$

$\begin{array}{lllll}\mathrm{C} & -3.62100800 & 0.52306900 & -0.19353300\end{array}$

$\begin{array}{llll}\mathrm{C} & 3.59172800 & 0.59568500 & -0.11424100\end{array}$

$\begin{array}{llll}\mathrm{H} & 3.20851300 & 1.33944400 & -0.82645500\end{array}$

$\begin{array}{llll}\mathrm{C} & 1.23807900 & -2.25628400 & -2.10993600\end{array}$

$\begin{array}{llll}\text { C } & -2.40643100 & -3.32481000 & 1.03606100\end{array}$

$\begin{array}{llll}\mathrm{C} & 4.93634900 & 0.08002900 & -0.61405200\end{array}$

$\begin{array}{llll}\mathrm{H} & 4.89561500 & -0.28446100 & -1.64586200\end{array}$ 


\begin{tabular}{|c|c|c|c|}
\hline $\mathrm{C}$ & -4.93092900 & -0.05692800 & -0.71595200 \\
\hline $\mathrm{C}$ & -2.28528900 & -1.40086900 & 2.61715600 \\
\hline $\mathrm{C}$ & 2.84096100 & -1.91071100 & 1.18812700 \\
\hline $\mathrm{H}$ & 3.93869700 & -1.82319200 & 1.19836300 \\
\hline $\mathrm{C}$ & 3.74616000 & 1.27360900 & 1.24313200 \\
\hline $\mathrm{C}$ & -3.85201400 & 1.23505900 & 1.13544500 \\
\hline $\mathrm{C}$ & -1.16456600 & -2.34852900 & -2.02216500 \\
\hline $\mathrm{C}$ & -2.44667100 & -1.62352400 & -1.68822900 \\
\hline $\mathrm{C}$ & 2.29851100 & -1.54369100 & 2.56692400 \\
\hline $\mathrm{C}$ & 2.48450800 & -1.48448300 & -1.74518500 \\
\hline $\mathrm{H}$ & 0.00674500 & -1.57223400 & 0.68020700 \\
\hline $\mathrm{H}$ & 2.78257300 & 1.58942200 & 1.65640600 \\
\hline $\mathrm{H}$ & 4.37580800 & 2.16690200 & 1.14566700 \\
\hline $\mathrm{H}$ & 4.23886400 & 0.60795400 & 1.96401700 \\
\hline $\mathrm{H}$ & 5.67622200 & 0.89053900 & -0.58252200 \\
\hline $\mathrm{H}$ & 5.32480300 & -0.73154300 & 0.01548900 \\
\hline $\mathrm{H}$ & 2.49845900 & -0.50344200 & 2.84523800 \\
\hline $\mathrm{H}$ & 2.64378600 & -0.65814200 & -2.45421400 \\
\hline $\mathrm{H}$ & 3.37107300 & -2.12953200 & -1.78971400 \\
\hline $\mathrm{H}$ & 1.25523000 & -2.58272100 & -3.16032100 \\
\hline $\mathrm{H}$ & 1.15681200 & -3.15745500 & -1.49143800 \\
\hline $\mathrm{H}$ & -1.18303800 & -2.75318000 & -3.04537100 \\
\hline $\mathrm{H}$ & -1.01308300 & -3.19167100 & -1.33783100 \\
\hline $\mathrm{H}$ & -2.65415600 & -0.85381100 & -2.44654600 \\
\hline $\mathrm{H}$ & -3.29989700 & -2.31321800 & -1.68274200 \\
\hline $\mathrm{H}$ & -2.82285500 & -3.74345500 & 0.11263600 \\
\hline $\mathrm{H}$ & -1.31274200 & -3.42562700 & 1.00445300 \\
\hline $\mathrm{H}$ & -2.76958400 & -3.94229700 & 1.86763500 \\
\hline $\mathrm{H}$ & -2.69598300 & -2.02569600 & 3.42064400 \\
\hline $\mathrm{H}$ & -3.90777000 & -1.81529500 & 1.26051200 \\
\hline $\mathrm{H}$ & -1.19135400 & -1.48607100 & 2.64615200 \\
\hline $\mathrm{H}$ & -2.54341200 & -0.35950400 & 2.83741400 \\
\hline $\mathrm{H}$ & -4.85079900 & -0.44261200 & -1.73738300 \\
\hline $\mathrm{H}$ & -5.30218600 & -0.86947600 & -0.07705000 \\
\hline $\mathrm{H}$ & -4.34447700 & 0.57177900 & 1.85858600 \\
\hline $\mathrm{H}$ & -5.70301100 & 0.72354400 & -0.72098100 \\
\hline $\mathrm{H}$ & -4.51453000 & 2.09683200 & 0.98567600 \\
\hline $\mathrm{H}$ & -2.92108700 & 1.60517600 & 1.57627300 \\
\hline $\mathrm{H}$ & -3.24196700 & 1.26011100 & -0.91546500 \\
\hline $\mathrm{H}$ & 2.74635600 & -2.18903600 & 3.33340100 \\
\hline $\mathrm{H}$ & 1.21121300 & -1.69132700 & 2.59094300 \\
\hline $\mathrm{P}$ & -0.01798200 & 2.77123400 & -0.07354800 \\
\hline $\mathrm{F}$ & 0.01056000 & 1.57182500 & -1.24406000 \\
\hline $\mathrm{F}$ & -0.02824400 & 3.89265700 & -1.22208200 \\
\hline $\mathrm{F}$ & -0.04500400 & 3.84557400 & 1.11608100 \\
\hline $\mathrm{F}$ & 1.59017400 & 2.76729800 & -0.06855600 \\
\hline $\mathrm{F}$ & -0.00467300 & 1.52836100 & 1.05563300 \\
\hline $\mathrm{F}$ & -1.62504800 & 2.71361600 & -0.09269900 \\
\hline
\end{tabular}

$\left({ }^{\mathrm{Pr}} \mathrm{PN}{ }^{\mathrm{H}} \mathrm{P}\right) \mathrm{Fe}(\mathrm{H})\left(\mathrm{OCH}_{3}\right)(9$ no CO singlet $) \quad \mathrm{G}_{\mathrm{THF}}=-1008703.093 \mathrm{kcal} / \mathrm{mol}$ $\begin{array}{llll}\mathrm{Fe} & -0.05630300 & 0.22232600 & 0.04368300\end{array}$ 


\begin{tabular}{|c|c|c|c|}
\hline $\mathrm{H}$ & -0.09970200 & -0.97622600 & 1.03296200 \\
\hline $\mathrm{P}$ & 2.16726100 & 0.01666100 & 0.03598400 \\
\hline $\mathrm{P}$ & -2.26121900 & -0.03513700 & -0.02752900 \\
\hline $\mathrm{N}$ & -0.01156100 & -0.93018000 & -1.63565900 \\
\hline $\mathrm{H}$ & -0.03027700 & -0.17000200 & -2.32284200 \\
\hline $\mathrm{C}$ & 2.42971400 & -0.82134500 & -1.60018600 \\
\hline $\mathrm{H}$ & 2.46531200 & -0.02355400 & -2.35705100 \\
\hline $\mathrm{H}$ & 3.36825900 & -1.38542900 & -1.67292800 \\
\hline $\mathrm{C}$ & 1.22497100 & -1.70299600 & -1.85897700 \\
\hline $\mathrm{H}$ & 1.23843200 & -2.11331100 & -2.88138300 \\
\hline $\mathrm{H}$ & 1.19925800 & -2.55162700 & -1.16298000 \\
\hline $\mathrm{C}$ & -1.20247500 & -1.76978500 & -1.86275500 \\
\hline $\mathrm{H}$ & -1.14688900 & -2.60180300 & -1.14865900 \\
\hline $\mathrm{H}$ & -1.17955000 & -2.19938500 & -2.87717000 \\
\hline $\mathrm{C}$ & -2.44962700 & -0.94213300 & -1.64031600 \\
\hline $\mathrm{H}$ & -3.36141100 & -1.54901200 & -1.70503800 \\
\hline $\mathrm{H}$ & -2.51398200 & -0.16830700 & -2.42059100 \\
\hline $\mathrm{C}$ & 3.07409200 & -1.05208900 & 1.27912900 \\
\hline $\mathrm{H}$ & 2.82977000 & -0.57834200 & 2.24395600 \\
\hline $\mathrm{C}$ & 4.58989600 & -1.11331800 & 1.12630500 \\
\hline $\mathrm{H}$ & 4.87979500 & -1.46403300 & 0.12632100 \\
\hline $\mathrm{H}$ & 5.00792100 & -1.82554600 & 1.84994400 \\
\hline $\mathrm{H}$ & 5.07715000 & -0.14915900 & 1.29964900 \\
\hline $\mathrm{C}$ & 2.50583000 & -2.46818200 & 1.29283400 \\
\hline $\mathrm{H}$ & 1.41153900 & -2.46729900 & 1.35440800 \\
\hline $\mathrm{H}$ & 2.90555700 & -3.02379700 & 2.15049400 \\
\hline $\mathrm{H}$ & 2.80461900 & -3.01720700 & 0.38870800 \\
\hline $\mathrm{C}$ & 3.14163300 & 1.60467700 & -0.12072700 \\
\hline $\mathrm{H}$ & 2.40348700 & 2.21533900 & -0.66704900 \\
\hline $\mathrm{C}$ & 4.42991600 & 1.58514300 & -0.93640100 \\
\hline $\mathrm{H}$ & 5.21930000 & 0.99581900 & -0.45752400 \\
\hline $\mathrm{H}$ & 4.81042200 & 2.60998100 & -1.04427500 \\
\hline $\mathrm{H}$ & 4.28309600 & 1.18742500 & -1.94652000 \\
\hline $\mathrm{C}$ & 3.36714400 & 2.23584500 & 1.25099400 \\
\hline $\mathrm{H}$ & 2.46333200 & 2.21604500 & 1.87356500 \\
\hline $\mathrm{H}$ & 3.67440900 & 3.28392000 & 1.14278100 \\
\hline $\mathrm{H}$ & 4.16222700 & 1.72134900 & 1.80613700 \\
\hline $\mathrm{C}$ & -3.17283400 & -1.09417200 & 1.21885000 \\
\hline $\mathrm{H}$ & -4.24872000 & -0.94156900 & 1.03379700 \\
\hline $\mathrm{C}$ & -2.85701200 & -2.57590600 & 1.05407500 \\
\hline $\mathrm{H}$ & -3.17332700 & -2.97550700 & 0.08386600 \\
\hline $\mathrm{H}$ & -3.37237500 & -3.15565400 & 1.83079200 \\
\hline $\mathrm{H}$ & -1.77843800 & -2.75180700 & 1.16846100 \\
\hline $\mathrm{C}$ & -2.83753300 & -0.66418300 & 2.64367300 \\
\hline $\mathrm{H}$ & -1.77287800 & -0.83912700 & 2.84298400 \\
\hline $\mathrm{H}$ & -3.41971500 & -1.25409400 & 3.36367000 \\
\hline $\mathrm{H}$ & -3.04350500 & 0.39394300 & 2.83522600 \\
\hline $\mathrm{C}$ & -3.42201400 & 1.41173100 & -0.30909200 \\
\hline $\mathrm{H}$ & -2.82202300 & 2.04824900 & -0.98039400 \\
\hline $\mathrm{C}$ & -4.73572100 & 1.06000400 & -0.99868300 \\
\hline $\mathrm{H}$ & -5.34884300 & 1.96293800 & -1.12045500 \\
\hline
\end{tabular}




$\begin{array}{lrrr}\mathrm{H} & -5.32548100 & 0.35072900 & -0.40209300 \\ \mathrm{H} & -4.59413500 & 0.62499900 & -1.99318100 \\ \mathrm{C} & -3.70624300 & 2.19178900 & 0.97118500 \\ \mathrm{H} & -4.41069200 & 1.64794400 & 1.61449600 \\ \mathrm{H} & -4.17130600 & 3.15618800 & 0.73042600 \\ \mathrm{H} & -2.80182800 & 2.39399000 & 1.55801100 \\ \mathrm{O} & 0.00102200 & 1.92531700 & -0.99030700 \\ \mathrm{C} & -0.09349600 & 2.37562400 & 0.26588500 \\ \mathrm{H} & -1.03306100 & 2.90608700 & 0.52049600 \\ \mathrm{H} & -0.08594500 & 1.51762900 & 1.14039100 \\ \mathrm{H} & 0.75874300 & 2.99037400 & 0.62330000\end{array}$

$\left({ }^{\mathrm{iPr}} \mathrm{PN}{ }^{\mathrm{H}} \mathrm{P}\right) \mathrm{Fe}(\mathrm{H})(\mathrm{OC}(\mathrm{H}) \mathrm{O})(\mathbf{1 0}$ no CO singlet $) \quad \mathrm{G}_{\mathrm{THF}}=-1055185.460 \mathrm{kcal} / \mathrm{mol}$ $\begin{array}{llll}\mathrm{Fe} & 0.00003300 & 0.07044200 & -0.18605600\end{array}$

$\begin{array}{llll}\mathrm{H} & 0.00012400 & 1.61069900 & -0.33618300\end{array}$

$\begin{array}{llll}\mathrm{P} & 2.23048300 & 0.16129700 & -0.03404600\end{array}$

$\mathrm{P} \quad \quad-2.23054100 \quad 0.16111700 \quad-0.03408800$

$\begin{array}{llll}\mathrm{O} & -0.00012300 & -1.94948300 & -0.36933000\end{array}$

$\begin{array}{llll}\mathrm{O} & 0.00067300 & -2.63484700 & 1.78003600\end{array}$

$\begin{array}{llll}\mathrm{N} & 0.00007300 & 0.20977900 & 1.83324900\end{array}$

$\begin{array}{llll}\mathrm{H} & 0.00029100 & -0.80260800 & 2.05408400\end{array}$

$\begin{array}{llll}\mathrm{C} & 0.00029900 & -2.82023900 & 0.55028300\end{array}$

$\begin{array}{llll}\mathrm{H} & 0.00033800 & -3.87358500 & 0.17963400\end{array}$

$\begin{array}{llll}\mathrm{C} & 2.45065500 & 0.19747700 & 1.81002200\end{array}$

$\begin{array}{llll}\mathrm{H} & 2.53847100 & -0.84562400 & 2.14536500\end{array}$

$\begin{array}{llll}\mathrm{H} & 3.35969100 & 0.72631500 & 2.12382100\end{array}$

$\begin{array}{llll}\mathrm{C} & 1.20784800 & 0.82495500 & 2.41032100\end{array}$

$\begin{array}{llll}\mathrm{H} & 1.19829800 & 0.71853100 & 3.50697300\end{array}$

$\begin{array}{llll}\mathrm{H} & 1.16476500 & 1.89914400 & 2.18343600\end{array}$

$\begin{array}{llll}\mathrm{C} & -1.20788100 & 0.82450600 & 2.41040600\end{array}$

$\begin{array}{llll}\mathrm{H} & -1.16511600 & 1.89873900 & 2.18368200\end{array}$

$\begin{array}{llll}\mathrm{H} & -1.19831500 & 0.71793200 & 3.50704200\end{array}$

$\begin{array}{llll}\text { C } & -2.45048900 & 0.19671700 & 1.81001500\end{array}$

$\begin{array}{llll}\mathrm{H} & -3.35971700 & 0.72504400 & 2.12410600\end{array}$

$\begin{array}{llll}\mathrm{H} & -2.53778100 & -0.84654100 & 2.14506000\end{array}$

$\begin{array}{llll}\mathrm{C} & 3.24878600 & 1.61057000 & -0.62420600\end{array}$

$\begin{array}{llll}\mathrm{H} & 4.28807600 & 1.40578200 & -0.32320600\end{array}$

$\begin{array}{llll}\mathrm{C} & 2.80285600 & 2.90901800 & 0.03631100\end{array}$

$\begin{array}{llll}\mathrm{H} & 1.74434200 & 3.10823300 & -0.17582500\end{array}$

$\mathrm{H} \quad 3.39401700 \quad 3.74727400 \quad-0.35422300$

$\begin{array}{llll}\mathrm{H} & 2.93584900 & 2.89408800 & 1.12443900\end{array}$

$\begin{array}{llll}\text { C } & 3.17644600 & 1.73573100 & -2.14153300\end{array}$

$\mathrm{H} \quad 3.61989900 \quad 0.87696300 \quad-2.65705900$

$\mathrm{H} \quad 3.71234000 \quad 2.63288900 \quad-2.47678800$

$\begin{array}{llll}\mathrm{H} & 2.13347900 & 1.82850900 & -2.47442200\end{array}$

C $\quad 3.21635700 \quad-1.35813300 \quad-0.49948000$

$\begin{array}{llll}\mathrm{H} & 2.80708400 & -2.10180800 & 0.20320000\end{array}$

C $\quad 4.71663100 \quad-1.24223700 \quad-0.26832800$

$\mathrm{H} \quad 5.17995800 \quad-0.55373300 \quad-0.98730000$

$\mathrm{H} \quad 5.19773800 \quad-2.21947300 \quad-0.40408800$

$\mathrm{H} \quad 4.96071100 \quad-0.88975500 \quad 0.74155400$ 


\begin{tabular}{|c|c|c|c|}
\hline $\mathrm{C}$ & 2.89467500 & -1.84637600 & -1.90763000 \\
\hline $\mathrm{H}$ & 1.81430400 & -1.96656200 & -2.03987100 \\
\hline $\mathrm{H}$ & 3.37267000 & -2.81843400 & -2.08656300 \\
\hline $\mathrm{H}$ & 3.26926700 & -1.15952800 & -2.67661900 \\
\hline $\mathrm{C}$ & -3.24908100 & 1.61045400 & -0.62363000 \\
\hline $\mathrm{H}$ & -4.28829700 & 1.40552600 & -0.32245700 \\
\hline $\mathrm{C}$ & -2.80306900 & 2.90874800 & 0.03718200 \\
\hline $\mathrm{H}$ & -2.93628800 & 2.89365100 & 1.12527900 \\
\hline $\mathrm{H}$ & -3.39403800 & 3.74715400 & -0.35332200 \\
\hline $\mathrm{H}$ & -1.74447900 & 3.10784400 & -0.17469900 \\
\hline $\mathrm{C}$ & -3.17705000 & 1.73611000 & -2.14092300 \\
\hline $\mathrm{H}$ & -2.13418900 & 1.82958500 & -2.47391900 \\
\hline $\mathrm{H}$ & -3.71349500 & 2.63307200 & -2.47582100 \\
\hline $\mathrm{H}$ & -3.62004600 & 0.87725500 & -2.65668700 \\
\hline $\mathrm{C}$ & -3.21629900 & -1.35827800 & -0.49982000 \\
\hline $\mathrm{H}$ & -2.80689900 & -2.10210900 & 0.20261600 \\
\hline $\mathrm{C}$ & -4.71656700 & -1.24262000 & -0.26846500 \\
\hline $\mathrm{H}$ & -5.19753700 & -2.21990700 & -0.40432700 \\
\hline $\mathrm{H}$ & -5.18010700 & -0.55405300 & -0.98724100 \\
\hline $\mathrm{H}$ & -4.96056600 & -0.89036300 & 0.74151800 \\
\hline $\mathrm{C}$ & -2.89468600 & -1.84611400 & -1.90811500 \\
\hline $\mathrm{H}$ & -3.26925700 & -1.15903400 & -2.67690400 \\
\hline $\mathrm{H}$ & -3.37272200 & -2.81810500 & -2.08730200 \\
\hline $\mathrm{H}$ & -1.81432300 & -1.96628000 & -2.04037900 \\
\hline \multicolumn{3}{|c|}{$\left({ }^{(\mathrm{Pr}} \mathrm{PN}^{\mathrm{H}} \mathrm{P}\right) \mathrm{Fe}(\mathrm{H})_{2}$ (2 no CO triplet) } & $\mathrm{G}_{\mathrm{THF}}=-936877.464 \mathrm{kcal} / \mathrm{mol}$ \\
\hline $\mathrm{Fe}$ & 0.00002200 & 0.20723700 & 0.04366200 \\
\hline $\mathrm{H}$ & 0.00007500 & -0.65402800 & 1.42343400 \\
\hline $\mathrm{P}$ & 2.20268900 & 0.08105600 & -0.09532800 \\
\hline $\mathrm{P}$ & -2.20267000 & 0.08104700 & -0.09521300 \\
\hline $\mathrm{N}$ & -0.00000800 & -1.30646600 & -1.58017100 \\
\hline $\mathrm{H}$ & -0.00014600 & -0.69831700 & -2.40033300 \\
\hline $\mathrm{C}$ & 2.43401600 & -1.15653500 & -1.48344900 \\
\hline $\mathrm{H}$ & 2.51051500 & -0.57758100 & -2.41600300 \\
\hline $\mathrm{H}$ & 3.36875800 & -1.72307000 & -1.37905100 \\
\hline $\mathrm{C}$ & 1.23622800 & -2.09224100 & -1.56591900 \\
\hline $\mathrm{H}$ & 1.31261700 & -2.74855600 & -2.44898400 \\
\hline $\mathrm{H}$ & 1.19172100 & -2.74354100 & -0.68104700 \\
\hline $\mathrm{C}$ & -1.23614400 & -2.09239400 & -1.56561500 \\
\hline $\mathrm{H}$ & -1.19143600 & -2.74357900 & -0.68066300 \\
\hline $\mathrm{H}$ & -1.31260400 & -2.74882800 & -2.44858700 \\
\hline $\mathrm{C}$ & -2.43401900 & -1.15682000 & -1.48310400 \\
\hline $\mathrm{H}$ & -3.36867900 & -1.72344400 & -1.37846900 \\
\hline $\mathrm{H}$ & -2.51073900 & -0.57803400 & -2.41574600 \\
\hline $\mathrm{C}$ & 3.28685200 & -0.63600900 & 1.25077800 \\
\hline $\mathrm{H}$ & 4.30754100 & -0.68174300 & 0.83952700 \\
\hline $\mathrm{C}$ & 2.84759600 & -2.04831600 & 1.61448300 \\
\hline $\mathrm{H}$ & 1.80171800 & -2.05170500 & 1.94928800 \\
\hline $\mathrm{H}$ & 3.46855600 & -2.43428500 & 2.43316200 \\
\hline $\mathrm{H}$ & 2.94187200 & -2.74820700 & 0.77564000 \\
\hline $\mathrm{C}$ & 3.27650200 & 0.25517100 & 2.48630100 \\
\hline
\end{tabular}




$\begin{array}{lrrr}\mathrm{H} & 3.72899000 & 1.23581400 & 2.30298900 \\ \mathrm{H} & 3.83599100 & -0.21753400 & 3.30376100 \\ \mathrm{H} & 2.24760200 & 0.41637500 & 2.83634900 \\ \mathrm{C} & 3.16635800 & 1.54203300 & -0.75723500 \\ \mathrm{H} & 2.70877000 & 1.65760800 & -1.75339000 \\ \mathrm{C} & 4.66187500 & 1.30955200 & -0.92420300 \\ \mathrm{H} & 5.16772600 & 1.24306400 & 0.04788300 \\ \mathrm{H} & 5.11718100 & 2.14906900 & -1.46522300 \\ \mathrm{H} & 4.88603400 & 0.39365200 & -1.48468100 \\ \mathrm{C} & 2.88176400 & 2.81985400 & 0.02241800 \\ \mathrm{H} & 1.80360100 & 2.97112400 & 0.15327100 \\ \mathrm{H} & 3.28836300 & 3.68836600 & -0.51142700 \\ \mathrm{H} & 3.34848800 & 2.80502600 & 1.01502300 \\ \mathrm{C} & -3.28691100 & -0.63579600 & 1.25094000 \\ \mathrm{H} & -4.30758200 & -0.68148500 & 0.83964400 \\ \mathrm{C} & -2.84776900 & -2.04812200 & 1.61472600 \\ \mathrm{H} & -2.94200300 & -2.74801100 & 0.77587600 \\ \mathrm{H} & -3.46883200 & -2.43404000 & 2.43334700 \\ \mathrm{H} & -1.80191500 & -2.05160700 & 1.94959000 \\ \mathrm{C} & -3.27656700 & 0.25545000 & 2.48640400 \\ \mathrm{H} & -2.24769400 & 0.41656600 & 2.83657500 \\ \mathrm{H} & -3.83620200 & -0.21713300 & 3.30383600 \\ \mathrm{H} & -3.72890900 & 1.23614000 & 2.30297100 \\ \mathrm{C} & -3.16628000 & 1.54192600 & -0.75746300 \\ \mathrm{H} & -2.70854600 & 1.65737900 & -1.75356400 \\ \mathrm{C} & -4.66177000 & 1.30944800 & -0.92465300 \\ \mathrm{H} & -5.11697600 & 2.14892100 & -1.46582400 \\ \mathrm{H} & -5.16778600 & 1.24306700 & 0.04735200 \\ \mathrm{H} & -4.88584600 & 0.39349700 & -1.48508400 \\ \mathrm{C} & -2.88180100 & 2.81984600 & 0.02207800 \\ \mathrm{H} & -3.34872400 & 2.80515300 & 1.01459300 \\ \mathrm{H} & -3.28826000 & 3.68831000 & -0.51195100 \\ \mathrm{H} & -1.80366000 & 2.97110000 & 0.15312900 \\ \mathrm{H} & 0.00002600 & 1.48775500 & -0.99203500 \\ & & & \\ & & & \end{array}$

$\begin{array}{lrrr}\left.\left[{ }^{\left({ }^{\mathrm{Pr} P N} \mathrm{P}\right.} \mathrm{P}\right) \mathrm{Fe}(\mathrm{H})(\mathrm{THF})\right]^{+}(\mathbf{5}-\mathbf{T H F} \text { no CO triplet }) \mathrm{G}_{\mathrm{THF}}=-1082174.608 \mathrm{kcal} / \mathrm{mol} \\ \mathrm{Fe} & -0.05233500 & -0.25208000 & -0.09365000 \\ \mathrm{P} & 2.14656700 & -0.64261700 & 0.02868000 \\ \mathrm{P} & -2.28622700 & -0.28978200 & -0.00101500 \\ \mathrm{~N} & -0.08467900 & -0.54103400 & 1.99174500 \\ \mathrm{H} & 0.06220200 & 0.41113800 & 2.33600100 \\ \mathrm{C} & 2.74740300 & -2.23194300 & -0.73459000 \\ \mathrm{C} & -2.65137600 & -3.04758300 & 0.11887900 \\ \mathrm{H} & -1.55499800 & -3.12316700 & 0.04650000 \\ \mathrm{H} & -3.07041100 & -3.95214300 & -0.33830700 \\ \mathrm{H} & -2.92998900 & -3.06077200 & 1.17788000 \\ \mathrm{C} & 3.43390900 & 0.65866700 & -0.32193300 \\ \mathrm{C} & -3.28856900 & 1.18974600 & -0.52187100 \\ \mathrm{H} & -2.79995600 & 1.98954400 & 0.05937900 \\ \mathrm{C} & -1.38676400 & -1.00747300 & 2.52876600 \\ \mathrm{C} & 1.80252500 & -3.36405900 & -0.34449200\end{array}$ 


\begin{tabular}{|c|c|c|c|}
\hline $\mathrm{C}$ & -4.75735000 & 1.11040600 & -0.12463900 \\
\hline $\mathrm{H}$ & -4.90082200 & 0.91975900 & 0.94478000 \\
\hline $\mathrm{C}$ & 4.86176100 & 0.19313400 & -0.06569400 \\
\hline $\mathrm{C}$ & 2.84904100 & -2.12800500 & -2.25126600 \\
\hline $\mathrm{C}$ & -3.16716100 & -1.81120000 & -0.61133600 \\
\hline $\mathrm{H}$ & -4.23598600 & -1.68179100 & -0.38033600 \\
\hline $\mathrm{C}$ & -3.14083300 & 1.52049900 & -2.00404700 \\
\hline $\mathrm{C}$ & 3.28106900 & 1.27664600 & -1.70729000 \\
\hline $\mathrm{C}$ & 1.04195300 & -1.37367200 & 2.47713600 \\
\hline $\mathrm{C}$ & 2.35990000 & -0.92977800 & 1.86285400 \\
\hline $\mathrm{C}$ & -2.98132800 & -1.97962700 & -2.11475700 \\
\hline $\mathrm{C}$ & -2.54329900 & -0.29748300 & 1.84594400 \\
\hline $\mathrm{H}$ & -0.05519000 & -0.52152900 & -1.64349200 \\
\hline $\mathrm{H}$ & -2.10892200 & 1.41137800 & -2.35833200 \\
\hline $\mathrm{H}$ & -3.45992200 & 2.55349100 & -2.19005400 \\
\hline $\mathrm{H}$ & -3.77817000 & 0.87484000 & -2.61972800 \\
\hline $\mathrm{H}$ & -5.25958100 & 2.05635300 & -0.36237000 \\
\hline $\mathrm{H}$ & -5.27483200 & 0.32112900 & -0.68509100 \\
\hline $\mathrm{H}$ & -3.38213100 & -1.14018500 & -2.69134400 \\
\hline $\mathrm{H}$ & -2.57413400 & 0.75745100 & 2.15746300 \\
\hline $\mathrm{H}$ & -3.50008600 & -0.74880700 & 2.13948100 \\
\hline $\mathrm{H}$ & -1.42145200 & -0.86466300 & 3.61832300 \\
\hline $\mathrm{H}$ & -1.43190100 & -2.08723900 & 2.34520300 \\
\hline $\mathrm{H}$ & 1.09030900 & -1.34911800 & 3.57563800 \\
\hline $\mathrm{H}$ & 0.80727100 & -2.40598300 & 2.18752200 \\
\hline $\mathrm{H}$ & 2.68349100 & 0.02257000 & 2.30757300 \\
\hline $\mathrm{H}$ & 3.14690500 & -1.66428200 & 2.07759500 \\
\hline $\mathrm{H}$ & 1.78711000 & -3.55198900 & 0.73467800 \\
\hline $\mathrm{H}$ & 0.77595400 & -3.14512200 & -0.67517900 \\
\hline $\mathrm{H}$ & 2.11292800 & -4.29638900 & -0.83166800 \\
\hline $\mathrm{H}$ & 3.05110900 & -3.11758700 & -2.67900800 \\
\hline $\mathrm{H}$ & 3.74332800 & -2.43402100 & -0.31035800 \\
\hline $\mathrm{H}$ & 1.90747800 & -1.76197200 & -2.68273100 \\
\hline $\mathrm{H}$ & 3.65605500 & -1.46316700 & -2.57506200 \\
\hline $\mathrm{H}$ & 4.99346400 & -0.22803100 & 0.93770600 \\
\hline $\mathrm{H}$ & 5.17021200 & -0.56551700 & -0.79582800 \\
\hline $\mathrm{H}$ & 3.61064800 & 0.59379400 & -2.49785400 \\
\hline $\mathrm{H}$ & 5.55432300 & 1.03791200 & -0.16465100 \\
\hline $\mathrm{H}$ & 3.89771500 & 2.18095100 & -1.78346200 \\
\hline $\mathrm{H}$ & 2.24118300 & 1.55098700 & -1.92170400 \\
\hline $\mathrm{H}$ & 3.17985100 & 1.43544500 & 0.41990900 \\
\hline $\mathrm{H}$ & -3.49224200 & -2.88889800 & -2.45394400 \\
\hline $\mathrm{H}$ & -1.91515300 & -2.07694700 & -2.35958100 \\
\hline $\mathrm{O}$ & -0.06758900 & 2.04958200 & 0.25467300 \\
\hline $\mathrm{C}$ & -0.05512300 & 2.88973100 & -0.91538000 \\
\hline $\mathrm{C}$ & 0.53190500 & 2.74804800 & 1.35779700 \\
\hline $\mathrm{C}$ & 0.94374600 & 3.98542200 & -0.60739400 \\
\hline $\mathrm{H}$ & 0.20358800 & 2.26375900 & -1.77890700 \\
\hline $\mathrm{H}$ & -1.06562200 & 3.29804200 & -1.07017700 \\
\hline $\mathrm{C}$ & 0.72580000 & 4.17856800 & 0.88860200 \\
\hline $\mathrm{H}$ & -0.12696000 & 2.66508500 & 2.23206600 \\
\hline
\end{tabular}




$\begin{array}{rrrr}\mathrm{H} & 1.49690800 & 2.27048200 & 1.59674400 \\ \mathrm{H} & 0.76883900 & 4.88961500 & -1.19633200 \\ \mathrm{H} & 1.96720300 & 3.63781300 & -0.80470900 \\ \mathrm{H} & -0.18279400 & 4.76582600 & 1.06892700 \\ \mathrm{H} & 1.55902600 & 4.67233600 & 1.39542600\end{array}$

$\left({ }^{\mathrm{iPr} P N}{ }^{\mathrm{H}} \mathrm{P}\right) \mathrm{Fe}(\mathrm{H})\left(\mathrm{PF}_{6}\right)(6$ no CO triplet $) \quad \mathrm{G}_{\mathrm{THF}}=-1526647.895 \mathrm{kcal} / \mathrm{mol}$

$\begin{array}{llll}\mathrm{Fe} & -0.00357800 & -0.30282300 & -0.04469700\end{array}$

$\begin{array}{llll}\mathrm{P} & -2.23663800 & -0.80410500 & -0.02503200\end{array}$

$\begin{array}{llll}\mathrm{P} & 2.21378200 & -0.86542600 & -0.02427000\end{array}$

$\begin{array}{llll}\mathrm{N} & -0.01739900 & -1.27474900 & -2.10744900\end{array}$

$\mathrm{H} \quad 0.02174300 \quad-0.48496600 \quad-2.75337200$

$\begin{array}{llll}\text { C } & -2.89779100 & -2.21052500 & 1.00489900\end{array}$

$\begin{array}{llll}\mathrm{C} & 2.36099100 & -3.61565500 & 0.58495300\end{array}$

$\mathrm{H} \quad 1.26313300 \quad-3.66515200 \quad 0.59889400$

$\mathrm{H} \quad 2.73280900 \quad-4.39097000 \quad 1.26629800$

$\mathrm{H} \quad 2.70876500 \quad-3.87012800 \quad-0.42232300$

$\begin{array}{llll}\text { C } & -3.48757400 & 0.56967500 & 0.13797100\end{array}$

$\begin{array}{llll}\mathrm{C} & 3.49896000 & 0.48201800 & 0.07513000\end{array}$

$\mathrm{H} \quad 3.11009300 \quad 1.21048100 \quad-0.65204100$

$\begin{array}{llll}\text { C } & 1.17410500 & -2.11062700 & -2.30552800\end{array}$

$\begin{array}{llll}\text { C } & -2.47801600 & -3.57317900 & 0.46896800\end{array}$

$\begin{array}{lllll}\text { C } & 4.89975600 & 0.05362600 & -0.34312500\end{array}$

$\mathrm{H} \quad 4.93000300 \quad-0.38776700 \quad-1.34537100$

$\begin{array}{lllll}\text { C } & -4.90318200 & 0.19172400 & -0.27882000\end{array}$

$\begin{array}{llll}\text { C } & -2.45146400 & -2.06651300 & 2.45638000\end{array}$

$\begin{array}{llll}\mathrm{C} & 2.84600600 & -2.24950300 & 1.05210800\end{array}$

$\begin{array}{llll}\mathrm{H} & 3.94376800 & -2.22018500 & 0.97077700\end{array}$

$\begin{array}{llll}\text { C } & 3.51082900 & 1.15743200 & 1.44081800\end{array}$

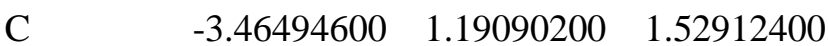

$\begin{array}{llll}\text { C } & -1.25775500 & -2.02472400 & -2.34831100\end{array}$

$\begin{array}{llll}\text { C } & -2.47421400 & -1.29201600 & -1.80530500\end{array}$

$\begin{array}{llll}\mathrm{C} & 2.43809500 & -2.02436400 & 2.50465100\end{array}$

C $\quad 2.42866500 \quad-1.42836400 \quad-1.78513400$

$\mathrm{H} \quad-0.01620200 \quad-1.63277900 \quad 0.74111100$

$\begin{array}{llll}\mathrm{H} & 2.49884700 & 1.41249700 & 1.77445400\end{array}$

$\begin{array}{llll}\mathrm{H} & 4.09064900 & 2.08734900 & 1.39080200\end{array}$

$\begin{array}{llll}\mathrm{H} & 3.98718200 & 0.51824500 & 2.19552100\end{array}$

$\mathrm{H} \quad \begin{array}{llll}\mathrm{H} & 5.56668100 & 0.92524500 & -0.34675000\end{array}$

$\mathrm{H} \quad 5.32699400 \quad-0.67178400 \quad 0.36129500$

$\mathrm{H} \quad 2.75903700 \quad-1.05351500 \quad 2.89584000$

$\mathrm{H} \quad 2.62337200 \quad-0.51383500 \quad-2.36620400$

$\mathrm{H} \quad 3.30441500 \quad-2.07940300 \quad-1.90964100$

$\mathrm{H} \quad 1.30354600 \quad-2.38949400 \quad-3.36446200$

$\mathrm{H} \quad 1.00113700 \quad-3.04290300 \quad-1.75166500$

$\mathrm{H} \quad-1.39456200 \quad-2.24834700 \quad-3.41900000$

$\mathrm{H} \quad-1.14829200 \quad-2.98987200 \quad-1.83735600$

$\mathrm{H} \quad-2.61562600 \quad-0.34652600 \quad-2.35140800$

$\mathrm{H} \quad-3.38376900 \quad-1.88887000 \quad-1.95656000$

$\mathrm{H} \quad-2.87120800 \quad-3.77682100 \quad-0.53309300$

$\mathrm{H} \quad-1.38276100 \quad-3.66092300 \quad 0.43953300$ 


$\begin{array}{crrr}\mathrm{H} & -2.85179800 & -4.36132400 & 1.13437700 \\ \mathrm{H} & -2.92168400 & -2.84383500 & 3.07146200 \\ \mathrm{H} & -3.99497800 & -2.13573600 & 0.95096600 \\ \mathrm{H} & -1.36260800 & -2.18834600 & 2.52951500 \\ \mathrm{H} & -2.70639600 & -1.09422600 & 2.89052000 \\ \mathrm{H} & -4.95461900 & -0.20943400 & -1.29698500 \\ \mathrm{H} & -5.34136100 & -0.54978400 & 0.40167300 \\ \mathrm{H} & -3.93866200 & 0.53081700 & 2.26749600 \\ \mathrm{H} & -5.54818600 & 1.07888900 & -0.24150500 \\ \mathrm{H} & -4.02907300 & 2.13176900 & 1.52580000 \\ \mathrm{H} & -2.44288300 & 1.41593500 & 1.85438600 \\ \mathrm{H} & -3.09130100 & 1.31738400 & -0.56498100 \\ \mathrm{H} & 2.87394600 & -2.80427000 & 3.14142600 \\ \mathrm{H} & 1.34569400 & -2.07800600 & 2.60262300 \\ \mathrm{P} & 0.04014100 & 2.97398600 & -0.06735000 \\ \mathrm{~F} & 0.00211900 & 1.56689500 & -1.02124400 \\ \mathrm{~F} & -0.00105900 & 3.84014900 & -1.42153400 \\ \mathrm{~F} & 0.07670100 & 4.27973900 & 0.86177700 \\ \mathrm{~F} & 1.65092700 & 2.92381500 & -0.13887500 \\ \mathrm{~F} & 0.07763800 & 1.99369100 & 1.24449200 \\ \mathrm{~F} & -1.57244500 & 2.93804000 & -0.03135800\end{array}$

\begin{tabular}{cccc}
$\left({ }^{\mathrm{iPr}} \mathrm{PN}^{\mathrm{H}} \mathrm{P}\right) \mathrm{Fe}(\mathrm{H})\left(\mathrm{OCH}_{3}\right)(\mathbf{9}$ no CO triplet $)$ & \multicolumn{1}{c}{$\mathrm{G}_{\mathrm{THF}}=-1008724.848 \mathrm{kcal} / \mathrm{mol}$} \\
$\mathrm{Fe}$ & 0.05768000 & 0.18762400 & -0.18994600 \\
$\mathrm{H}$ & 0.09471600 & -0.45482200 & -1.64857900 \\
$\mathrm{P}$ & -2.15884600 & 0.01932900 & -0.13967600 \\
$\mathrm{P}$ & 2.25437700 & -0.10244400 & 0.01939900 \\
$\mathrm{~N}$ & -0.02650800 & -0.43231100 & 1.88765300 \\
$\mathrm{H}$ & 0.07617300 & 0.50536900 & 2.28517800 \\
$\mathrm{C}$ & -2.45882100 & -0.17319400 & 1.68928800 \\
$\mathrm{H}$ & -2.44873300 & 0.85195500 & 2.09022000 \\
$\mathrm{H}$ & -3.43438000 & -0.61222300 & 1.93638800 \\
$\mathrm{C}$ & -1.32605300 & -0.97035000 & 2.32088000 \\
$\mathrm{H}$ & -1.40884500 & -0.96470800 & 3.41971900 \\
$\mathrm{H}$ & -1.36327700 & -2.02058100 & 2.00363600 \\
$\mathrm{C}$ & 1.12366500 & -1.24893300 & 2.30323800 \\
$\mathrm{H}$ & 0.97985800 & -2.24526600 & 1.86179200 \\
$\mathrm{H}$ & 1.14402800 & -1.38029200 & 3.39770800 \\
$\mathrm{C}$ & 2.42171000 & -0.62202700 & 1.81146300 \\
$\mathrm{H}$ & 3.26820900 & -1.30235800 & 1.97465700 \\
$\mathrm{H}$ & 2.62811600 & 0.29276300 & 2.38655000 \\
$\mathrm{C}$ & -2.95584800 & -1.45191100 & -0.96087300 \\
$\mathrm{H}$ & -2.71278400 & -1.29439000 & -2.02389100 \\
$\mathrm{C}$ & -4.46504100 & -1.58659800 & -0.80721600 \\
$\mathrm{H}$ & -4.76546000 & -1.58735200 & 0.24941400 \\
$\mathrm{H}$ & -4.80279200 & -2.53770100 & -1.23973400 \\
$\mathrm{H}$ & -5.01212100 & -0.78488500 & -1.31346100 \\
$\mathrm{C}$ & -2.25768800 & -2.73077800 & -0.50475600 \\
$\mathrm{H}$ & -1.16342800 & -2.63182100 & -0.51765700 \\
$\mathrm{H}$ & -2.53155700 & -3.56853700 & -1.15772200 \\
$\mathrm{H}$ & -2.56814300 & -3.00241700 & 0.51338000 \\
& & &
\end{tabular}




$\begin{array}{lrrr}\mathrm{C} & -3.11112800 & 1.54240000 & -0.60292900 \\ \mathrm{H} & -2.41175800 & 2.30031500 & -0.21508700 \\ \mathrm{C} & -4.47769800 & 1.74431700 & 0.03968600 \\ \mathrm{H} & -5.22600300 & 1.03863800 & -0.33829900 \\ \mathrm{H} & -4.84326800 & 2.75459700 & -0.18764000 \\ \mathrm{H} & -4.44802100 & 1.64760200 & 1.13090100 \\ \mathrm{C} & -3.16798600 & 1.67706500 & -2.12029500 \\ \mathrm{H} & -2.17455100 & 1.56484400 & -2.57365500 \\ \mathrm{H} & -3.55558500 & 2.66457200 & -2.40038300 \\ \mathrm{H} & -3.83202800 & 0.92760000 & -2.57243900 \\ \mathrm{C} & 3.04792500 & -1.53021600 & -0.89048100 \\ \mathrm{H} & 4.06337500 & -1.64337400 & -0.47958900 \\ \mathrm{C} & 2.27230100 & -2.81715600 & -0.63752400 \\ \mathrm{H} & 2.30593200 & -3.12857100 & 0.41288300 \\ \mathrm{H} & 2.69468500 & -3.63617600 & -1.23387700 \\ \mathrm{H} & 1.21964700 & -2.69811700 & -0.93066300 \\ \mathrm{C} & 3.13459800 & -1.25037200 & -2.38524400 \\ \mathrm{H} & 2.13635800 & -1.04383600 & -2.79417300 \\ \mathrm{H} & 3.54220800 & -2.12331900 & -2.91110300 \\ \mathrm{H} & 3.77907800 & -0.39526100 & -2.61931800 \\ \mathrm{C} & 3.50265200 & 1.28752300 & -0.10444000 \\ \mathrm{H} & 3.32087100 & 1.85031500 & 0.82418700 \\ \mathrm{C} & 4.96311600 & 0.85668300 & -0.11320400 \\ \mathrm{H} & 5.61334700 & 1.73944100 & -0.06092700 \\ \mathrm{H} & 5.22543200 & 0.31702300 & -1.03202100 \\ \mathrm{H} & 5.21175200 & 0.21280300 & 0.73967800 \\ \mathrm{C} & 3.15477200 & 2.20817400 & -1.26996200 \\ \mathrm{H} & 3.26292200 & 1.70037800 & -2.23705500 \\ \mathrm{H} & 3.82161200 & 3.08009700 & -1.28137300 \\ \mathrm{H} & 2.11927100 & 2.56030700 & -1.18904000 \\ \mathrm{O} & -0.20902400 & 2.11492600 & 0.28944200 \\ \mathrm{C} & 0.45447300 & 2.80228800 & 1.26235200 \\ \mathrm{H} & 0.22441900 & 3.88786000 & 1.25277000 \\ \mathrm{H} & 0.20090100 & 2.47635900 & 2.30576600 \\ \mathrm{H} & 1.56524100 & 2.73694500 & 1.20661500 \\ & & & \\ & & \end{array}$

$\begin{array}{lrrr}{ }_{\left({ }^{\mathrm{Pr}} \mathrm{PN}^{\mathrm{H}} \mathrm{P}\right) \mathrm{Fe}(\mathrm{H})(\mathrm{OC}(\mathrm{H}) \mathrm{O})} & (\mathbf{1 0} \text { no CO triplet }) & \mathrm{G}_{\mathrm{THF}}=-1055211.410 \mathrm{kcal} / \mathrm{mol} \\ \mathrm{Fe} & 0.00004200 & 0.04983500 & -0.18336400 \\ \mathrm{H} & 0.00011000 & 0.77652200 & -1.60080800 \\ \mathrm{P} & 2.21333800 & 0.15471000 & -0.02104500 \\ \mathrm{P} & -2.21327400 & 0.15486500 & -0.02109900 \\ \mathrm{O} & 0.00007100 & -2.07032300 & -0.42588100 \\ \mathrm{O} & -0.00051400 & -2.75663300 & 1.72332000 \\ \mathrm{~N} & -0.00000700 & 0.07337400 & 1.91652600 \\ \mathrm{H} & -0.00023500 & -0.96171400 & 2.02044000 \\ \mathrm{C} & -0.00016100 & -2.94054300 & 0.49063800 \\ \mathrm{H} & -0.00003900 & -3.99752500 & 0.12865100 \\ \mathrm{C} & 2.45335900 & 0.05195300 & 1.82844400 \\ \mathrm{H} & 2.55618100 & -1.01544900 & 2.07074200 \\ \mathrm{H} & 3.36748700 & 0.55775600 & 2.16617000 \\ \mathrm{C} & 1.22513900 & 0.61290900 & 2.52876700\end{array}$




\begin{tabular}{|c|c|c|c|}
\hline $\mathrm{H}$ & 1.25280500 & 0.38448300 & 3.60641200 \\
\hline $\mathrm{H}$ & 1.18536800 & 1.70747400 & 2.43445100 \\
\hline $\mathrm{C}$ & -1.22499100 & 0.61345400 & 2.52860500 \\
\hline $\mathrm{H}$ & -1.18488700 & 1.70798500 & 2.43397100 \\
\hline $\mathrm{H}$ & -1.25274400 & 0.38533900 & 3.60631500 \\
\hline $\mathrm{C}$ & -2.45335600 & 0.05265600 & 1.82841700 \\
\hline $\mathrm{H}$ & -3.36734600 & 0.55881300 & 2.16598100 \\
\hline $\mathrm{H}$ & -2.55648700 & -1.01464900 & 2.07100900 \\
\hline $\mathrm{C}$ & 3.13335800 & 1.70617400 & -0.48839300 \\
\hline $\mathrm{H}$ & 4.16243400 & 1.59554200 & -0.11179400 \\
\hline $\mathrm{C}$ & 2.48603400 & 2.90655100 & 0.19466200 \\
\hline $\mathrm{H}$ & 1.41495200 & 2.96879200 & -0.04935400 \\
\hline $\mathrm{H}$ & 2.95793400 & 3.83609200 & -0.14759300 \\
\hline $\mathrm{H}$ & 2.58623800 & 2.87226500 & 1.28526200 \\
\hline $\mathrm{C}$ & 3.16309900 & 1.90271300 & -1.99863800 \\
\hline $\mathrm{H}$ & 3.74235100 & 1.12760000 & -2.51250700 \\
\hline $\mathrm{H}$ & 3.61846600 & 2.87046700 & -2.24394400 \\
\hline $\mathrm{H}$ & 2.14469000 & 1.89436100 & -2.41000300 \\
\hline $\mathrm{C}$ & 3.22957500 & -1.28064900 & -0.63604500 \\
\hline $\mathrm{H}$ & 2.88623600 & -2.09501200 & 0.02161800 \\
\hline $\mathrm{C}$ & 4.73058100 & -1.10138600 & -0.45235500 \\
\hline $\mathrm{H}$ & 5.12690000 & -0.32218200 & -1.11619000 \\
\hline $\mathrm{H}$ & 5.25423400 & -2.03332500 & -0.70031500 \\
\hline $\mathrm{H}$ & 4.99759900 & -0.83510800 & 0.57782400 \\
\hline $\mathrm{C}$ & 2.85890100 & -1.66584500 & -2.06420600 \\
\hline $\mathrm{H}$ & 1.78933600 & -1.89028900 & -2.13571900 \\
\hline $\mathrm{H}$ & 3.42169000 & -2.55793000 & -2.36816400 \\
\hline $\mathrm{H}$ & 3.09705100 & -0.87077400 & -2.78136500 \\
\hline $\mathrm{C}$ & -3.13324100 & 1.70623400 & -0.48887200 \\
\hline $\mathrm{H}$ & -4.16234300 & 1.59569200 & -0.11231600 \\
\hline $\mathrm{C}$ & -2.48596600 & 2.90675700 & 0.19396900 \\
\hline $\mathrm{H}$ & -2.58604200 & 2.87260100 & 1.28458600 \\
\hline $\mathrm{H}$ & -2.95799800 & 3.83620800 & -0.14835200 \\
\hline $\mathrm{H}$ & -1.41492400 & 2.96907200 & -0.05018300 \\
\hline $\mathrm{C}$ & -3.16288300 & 1.90247400 & -1.99915700 \\
\hline $\mathrm{H}$ & -2.14444200 & 1.89409400 & -2.41043900 \\
\hline $\mathrm{H}$ & -3.61827300 & 2.87016300 & -2.24467900 \\
\hline $\mathrm{H}$ & -3.74206100 & 1.12724200 & -2.51292700 \\
\hline $\mathrm{C}$ & -3.22960000 & -1.28060700 & -0.63569800 \\
\hline $\mathrm{H}$ & -2.88619900 & -2.09485200 & 0.02207900 \\
\hline $\mathrm{C}$ & -4.73058200 & -1.10129100 & -0.45185100 \\
\hline $\mathrm{H}$ & -5.25427200 & -2.03328100 & -0.69954200 \\
\hline $\mathrm{H}$ & -5.12698600 & -0.32222600 & -1.11579800 \\
\hline $\mathrm{H}$ & -4.99746100 & -0.83479100 & 0.57830700 \\
\hline $\mathrm{C}$ & -2.85909900 & -1.66605000 & -2.06383700 \\
\hline $\mathrm{H}$ & -3.09725600 & -0.87106800 & -2.78109300 \\
\hline $\mathrm{H}$ & -3.42198300 & -2.55813800 & -2.36761200 \\
\hline $\mathrm{H}$ & -1.78955600 & -1.89057200 & -2.13540800 \\
\hline
\end{tabular}

$\left[\left({ }^{\mathrm{iPr} P N}{ }^{\mathrm{H}} \mathrm{P}\right) \mathrm{Fe}(\mathrm{H})(\mathrm{THF})\right]^{+}$(5-THF no CO quintet) $\quad \mathrm{G}_{\mathrm{THF}}=-1082185.125 \mathrm{kcal} / \mathrm{mol}$ $\begin{array}{llll}\mathrm{Fe} & 0.07924800 & -0.31447600 & 0.30564300\end{array}$ 


\begin{tabular}{|c|c|c|c|}
\hline $\mathrm{P}$ & -2.48210900 & -0.45422000 & -0.09583400 \\
\hline $\mathrm{P}$ & 2.61147700 & -0.38813600 & -0.09995900 \\
\hline $\mathrm{N}$ & 0.11239000 & -1.56455300 & -1.51978300 \\
\hline $\mathrm{H}$ & 0.14552100 & -0.90727300 & -2.30418900 \\
\hline $\mathrm{C}$ & -3.45243200 & -1.46258700 & 1.14593900 \\
\hline $\mathrm{C}$ & 3.17485500 & -2.60887400 & 1.49138700 \\
\hline $\mathrm{H}$ & 2.15619900 & -2.53878800 & 1.89666600 \\
\hline $\mathrm{H}$ & 3.81071600 & -3.07177300 & 2.25644900 \\
\hline $\mathrm{H}$ & 3.15861100 & -3.28762900 & 0.63051700 \\
\hline $\mathrm{C}$ & -3.68315300 & 0.86483500 & -0.67346000 \\
\hline $\mathrm{C}$ & 3.58156900 & 1.04369900 & -0.80921700 \\
\hline $\mathrm{H}$ & 3.02963200 & 1.24123800 & -1.74407700 \\
\hline $\mathrm{C}$ & 1.32453200 & -2.40623700 & -1.56827800 \\
\hline $\mathrm{C}$ & -3.03612700 & -2.92941000 & 1.15646600 \\
\hline $\mathrm{C}$ & 5.02640300 & 0.71589800 & -1.16419100 \\
\hline $\mathrm{H}$ & 5.11361600 & -0.17079900 & -1.80360500 \\
\hline $\mathrm{C}$ & -4.88899900 & 0.33542900 & -1.44258600 \\
\hline $\mathrm{C}$ & -3.26739900 & -0.86650500 & 2.54064800 \\
\hline $\mathrm{C}$ & 3.71887700 & -1.22714900 & 1.14091100 \\
\hline $\mathrm{H}$ & 4.70864300 & -1.34365300 & 0.67237700 \\
\hline $\mathrm{C}$ & 3.48767300 & 2.29542500 & 0.05921200 \\
\hline $\mathrm{C}$ & -4.13956600 & 1.75506200 & 0.47826800 \\
\hline $\mathrm{C}$ & -1.11307500 & -2.37533600 & -1.64987600 \\
\hline $\mathrm{C}$ & -2.36280800 & -1.50995200 & -1.62380400 \\
\hline $\mathrm{C}$ & 3.83969300 & -0.36691800 & 2.39469800 \\
\hline $\mathrm{C}$ & 2.59055100 & -1.56338200 & -1.54430700 \\
\hline $\mathrm{H}$ & 0.04758500 & -1.19728300 & 1.72392900 \\
\hline $\mathrm{H}$ & 2.46253600 & 2.47515000 & 0.40673800 \\
\hline $\mathrm{H}$ & 3.81695100 & 3.17441100 & -0.50977300 \\
\hline $\mathrm{H}$ & 4.13352200 & 2.22317200 & 0.94241300 \\
\hline $\mathrm{H}$ & 5.48138500 & 1.55858500 & -1.70046300 \\
\hline $\mathrm{H}$ & 5.62782300 & 0.54463300 & -0.26198800 \\
\hline $\mathrm{H}$ & 4.35303300 & 0.58259300 & 2.20824300 \\
\hline $\mathrm{H}$ & 2.64086500 & -0.95365100 & -2.45870200 \\
\hline $\mathrm{H}$ & 3.47518200 & -2.21370200 & -1.54996800 \\
\hline $\mathrm{H}$ & 1.30888000 & -3.04196400 & -2.46722400 \\
\hline $\mathrm{H}$ & 1.27991300 & -3.07858200 & -0.69920100 \\
\hline $\mathrm{H}$ & -1.08175200 & -2.96212300 & -2.58122000 \\
\hline $\mathrm{H}$ & -1.10975600 & -3.09449300 & -0.81930700 \\
\hline $\mathrm{H}$ & -2.33316300 & -0.80935900 & -2.47335000 \\
\hline $\mathrm{H}$ & -3.25561200 & -2.13402600 & -1.76127200 \\
\hline $\mathrm{H}$ & -3.22102400 & -3.43367700 & 0.20138300 \\
\hline $\mathrm{H}$ & -1.97265200 & -3.03417600 & 1.41149300 \\
\hline $\mathrm{H}$ & -3.60955600 & -3.46540200 & 1.92340200 \\
\hline $\mathrm{H}$ & -3.86633800 & -1.42580000 & 3.27069700 \\
\hline $\mathrm{H}$ & -4.51278000 & -1.40067700 & 0.85384700 \\
\hline $\mathrm{H}$ & -2.21323900 & -0.93534100 & 2.84140000 \\
\hline $\mathrm{H}$ & -3.56696800 & 0.18504500 & 2.60293600 \\
\hline $\mathrm{H}$ & -4.61148700 & -0.19352200 & -2.36007500 \\
\hline $\mathrm{H}$ & -5.49333200 & -0.34420100 & -0.82741600 \\
\hline $\mathrm{H}$ & -4.86429200 & 1.23368600 & 1.11680400 \\
\hline
\end{tabular}




$\begin{array}{lrrr}\mathrm{H} & -5.53857100 & 1.17218700 & -1.73060500 \\ \mathrm{H} & -4.64047100 & 2.64843800 & 0.08484900 \\ \mathrm{H} & -3.31065400 & 2.08801300 & 1.11623200 \\ \mathrm{H} & -3.07259300 & 1.47586600 & -1.35953200 \\ \mathrm{H} & 4.40815500 & -0.90116200 & 3.16631600 \\ \mathrm{H} & 2.84691400 & -0.14049600 & 2.80961000 \\ \mathrm{O} & 0.06638600 & 1.79644100 & 0.20287400 \\ \mathrm{C} & -0.37862100 & 2.63415100 & 1.29661900 \\ \mathrm{C} & -0.01355000 & 2.50745700 & -1.05246400 \\ \mathrm{C} & -0.93518800 & 3.88056700 & 0.63222900 \\ \mathrm{H} & -1.11133200 & 2.06434300 & 1.88421200 \\ \mathrm{H} & 0.49444600 & 2.84614400 & 1.92897300 \\ \mathrm{C} & -0.11669700 & 3.96427400 & -0.65395200 \\ \mathrm{H} & 0.87891500 & 2.25332900 & -1.63784000 \\ \mathrm{H} & -0.90570400 & 2.15879100 & -1.59739200 \\ \mathrm{H} & -0.83762000 & 4.76491500 & 1.26758300 \\ \mathrm{H} & -1.99887500 & 3.74869300 & 0.39230300 \\ \mathrm{H} & 0.88075000 & 4.37619900 & -0.45332000 \\ \mathrm{H} & -0.59005200 & 4.57352200 & -1.42866100\end{array}$

$\left({ }^{\mathrm{iPr}} \mathrm{PN}{ }^{\mathrm{H}} \mathrm{P}\right) \mathrm{Fe}(\mathrm{H})\left(\mathrm{OCH}_{3}\right)(9$ no CO quintet $) \quad \mathrm{G}_{\mathrm{THF}}=-1008749.054 \mathrm{kcal} / \mathrm{mol}$ $\mathrm{Fe}$

$\mathrm{H}$

\section{$\mathrm{P}$}

$\mathrm{P}$

$\mathrm{N}$

$\mathrm{H}$

C

$\mathrm{H}$

$\mathrm{H}$

C

$\mathrm{H}$

$\mathrm{H}$

C

$\mathrm{H}$

$\mathrm{H}$

C

$\mathrm{H}$

H

C

$\mathrm{H}$

C

$\mathrm{H}$

H

H

C

$\mathrm{H}$

$\mathrm{H}$

$\mathrm{H}$

C

H

$\begin{array}{lll}-0.04042500 & -0.34655700 & -0.47554700\end{array}$

$\begin{array}{lll}-0.03802100 & 0.13535000 & -2.14079900\end{array}$

$\begin{array}{llll}2.41265400 & 0.02301900 & -0.09953900\end{array}$

$\begin{array}{lll}-2.49562200 & 0.16393800 & 0.03866300\end{array}$

$\begin{array}{lll}0.03825000 & 0.63251500 & 1.74922200\end{array}$

$\begin{array}{lll}-0.06094800 & -0.22627800 & 2.29620500\end{array}$

$\begin{array}{lll}2.51674800 & 0.44610300 & 1.70305400\end{array}$

$\begin{array}{lll}2.51738800 & -0.51219700 & 2.24532500\end{array}$

$\begin{array}{lll}3.44481700 & 0.96588400 & 1.97783700\end{array}$

$\begin{array}{lll}1.30831700 & 1.27051500 & 2.12749900\end{array}$

$\begin{array}{lll}1.34144400 & 1.45833300 & 3.21401900\end{array}$

$\begin{array}{lll}1.32725700 & 2.25531400 & 1.64188200\end{array}$

$\begin{array}{lll}-1.09888700 & 1.51137500 & 2.05458500\end{array}$

$\begin{array}{lll}-0.98268600 & 2.40837300 & 1.42795600\end{array}$

$\begin{array}{lll}-1.06240800 & 1.85241000 & 3.10379300\end{array}$

$\begin{array}{lll}-2.43098400 & 0.83181300 & 1.77644300\end{array}$

$\begin{array}{lll}-3.25772300 & 1.52662100 & 1.97850900\end{array}$

$\begin{array}{lll}-2.55939100 & -0.01992000 & 2.46147000\end{array}$

$\begin{array}{llll}3.27766800 & 1.39324400 & -1.02304900\end{array}$

$\begin{array}{lll}3.15451900 & 1.08667400 & -2.07489800\end{array}$

$\begin{array}{lll}4.75801300 & 1.61013900 & -0.73628900\end{array}$

$\begin{array}{lll}4.94440800 & 1.76799900 & 0.33503200\end{array}$

$\begin{array}{llll}5.11403900 & 2.50631000 & -1.26267000\end{array}$

$\begin{array}{llll}5.37656200 & 0.76972300 & -1.06753600\end{array}$

$\begin{array}{llll}2.49691800 & 2.69245100 & -0.82321500\end{array}$

$\begin{array}{llll}1.41246700 & 2.55393800 & -0.94349000\end{array}$

$\begin{array}{llll}2.82267200 & 3.44570800 & -1.55136000\end{array}$

$\begin{array}{lll}2.68186500 & 3.11081600 & 0.17573800\end{array}$

$3.42298500 \quad-1.53223500 \quad-0.26528900$

$\begin{array}{lll}2.72428900 & -2.28231900 & 0.14128900\end{array}$ 


$\begin{array}{lrrr}\mathrm{C} & 4.72795300 & -1.61583100 & 0.51783000 \\ \mathrm{H} & 5.48412600 & -0.92141700 & 0.13480200 \\ \mathrm{H} & 5.14339300 & -2.62906700 & 0.43233600 \\ \mathrm{H} & 4.59177600 & -1.40784200 & 1.58541000 \\ \mathrm{C} & 3.62506900 & -1.84521400 & -1.74528900 \\ \mathrm{H} & 2.68104800 & -1.80046100 & -2.30391600 \\ \mathrm{H} & 4.04258100 & -2.85253300 & -1.86760900 \\ \mathrm{H} & 4.32844400 & -1.14207000 & -2.21184900 \\ \mathrm{C} & -3.50259000 & 1.45713500 & -0.85527900 \\ \mathrm{H} & -4.44493000 & 1.59315700 & -0.30081300 \\ \mathrm{C} & -2.73768200 & 2.77822500 & -0.85706200 \\ \mathrm{H} & -2.61416700 & 3.19384600 & 0.14982900 \\ \mathrm{H} & -3.27807700 & 3.52522900 & -1.45270100 \\ \mathrm{H} & -1.73906600 & 2.65741300 & -1.30275700 \\ \mathrm{C} & -3.81045700 & 1.01747400 & -2.28260800 \\ \mathrm{H} & -2.88846200 & 0.77175700 & -2.82722000 \\ \mathrm{H} & -4.31195300 & 1.82886100 & -2.82606600 \\ \mathrm{H} & -4.46807100 & 0.14185000 & -2.32158200 \\ \mathrm{C} & -3.60566200 & -1.32468300 & 0.24830500 \\ \mathrm{H} & -3.15892100 & -1.81863000 & 1.12723500 \\ \mathrm{C} & -5.05809000 & -0.99649400 & 0.56938600 \\ \mathrm{H} & -5.60774300 & -1.91659500 & 0.80801700 \\ \mathrm{H} & -5.56450600 & -0.53072600 & -0.28617500 \\ \mathrm{H} & -5.15519700 & -0.31973700 & 1.42773700 \\ \mathrm{C} & -3.47159300 & -2.28882200 & -0.92716800 \\ \mathrm{H} & -3.87457800 & -1.86236000 & -1.85467600 \\ \mathrm{H} & -4.03262400 & -3.21047500 & -0.72285300 \\ \mathrm{H} & -2.41963600 & -2.55092400 & -1.09776500 \\ \mathrm{O} & -0.05270400 & -2.22700700 & -0.24694300 \\ \mathrm{C} & -0.17292200 & -2.86479200 & 0.97204000 \\ \mathrm{H} & -0.27426500 & -3.95872300 & 0.85173200 \\ \mathrm{H} & 0.70480500 & -2.70575500 & 1.63521000 \\ \mathrm{H} & -1.06388700 & -2.53539300 & 1.55035900 \\ & & & \\ & & & \end{array}$

$\left({ }^{\mathrm{iPr}} \mathrm{PN}^{\mathrm{H}} \mathrm{P}\right) \mathrm{Fe}(\mathrm{H})(\mathrm{OC}(\mathrm{H}) \mathrm{O})(\mathbf{1 0}$ no CO quintet $) \mathrm{G}_{\mathrm{THF}}=-1055229.122 \mathrm{kcal} / \mathrm{mol}$

$\begin{array}{lllll}\mathrm{Fe} & & -0.00002000 & 0.17818500 & -0.51507400\end{array}$

$\mathrm{H} \quad-0.00004700 \quad 1.41566500 \quad-1.67371500$

$\begin{array}{llll}\mathrm{P} & 2.56861000 & 0.13548900 & -0.01619900\end{array}$

$\mathrm{P} \quad-2.56861800 \quad 0.13512800 \quad-0.01600300$

O $\quad 0.00059500 \quad-1.83051300-0.81370600$

$\begin{array}{llll}\mathrm{O} & -0.00090100 & -2.19494700 & 1.40584900\end{array}$

$\begin{array}{llll}\mathrm{N} & 0.00009000 & 0.82254800 & 1.60780400\end{array}$

$\begin{array}{llll}\mathrm{H} & 0.00075000 & -0.11445500 & 2.02818300\end{array}$

$\begin{array}{llll}\mathrm{C} & 0.00059000 & -2.57457800 & 0.22499200\end{array}$

$\begin{array}{llll}\mathrm{H} & 0.00219700 & -3.66552600 & 0.00978600\end{array}$

$\begin{array}{llll}\mathrm{C} & 2.46501900 & 0.71215200 & 1.75341600\end{array}$

$\mathrm{H} \quad 2.43288300 \quad-0.18759300 \quad 2.38573400$

$\begin{array}{llll}\mathrm{H} & 3.36072200 & 1.27587800 & 2.04715600\end{array}$

$\begin{array}{llll}\mathrm{C} & 1.21670400 & 1.54432700 & 2.00648000\end{array}$

$\mathrm{H} \quad 1.16415600 \quad 1.82389500 \quad 3.07187900$

$\begin{array}{llll}\mathrm{H} & 1.24115200 & 2.48309600 & 1.43242600\end{array}$ 


\begin{tabular}{|c|c|c|c|}
\hline $\mathrm{C}$ & -1.21691000 & 1.54318600 & 2.00740200 \\
\hline $\mathrm{H}$ & -1.24197800 & 2.48240700 & 1.43413600 \\
\hline $\mathrm{H}$ & -1.16421600 & 1.82189200 & 3.07301300 \\
\hline $\mathrm{C}$ & -2.46486400 & 0.71057700 & 1.75396500 \\
\hline $\mathrm{H}$ & -3.36074100 & 1.27365600 & 2.04842700 \\
\hline $\mathrm{H}$ & -2.43218900 & -0.18963600 & 2.38559100 \\
\hline $\mathrm{C}$ & 3.79019900 & 1.33023700 & -0.76759500 \\
\hline $\mathrm{H}$ & 4.73200000 & 1.24779600 & -0.20200700 \\
\hline $\mathrm{C}$ & 3.26703800 & 2.75852500 & -0.64518100 \\
\hline $\mathrm{H}$ & 2.28684000 & 2.86202200 & -1.13109400 \\
\hline $\mathrm{H}$ & 3.95971200 & 3.45204000 & -1.13926400 \\
\hline $\mathrm{H}$ & 3.16940900 & 3.08486300 & 0.39684100 \\
\hline $\mathrm{C}$ & 4.03744200 & 0.98187000 & -2.23151000 \\
\hline $\mathrm{H}$ & 4.53759300 & 0.01537800 & -2.35641000 \\
\hline $\mathrm{H}$ & 4.67251300 & 1.74414300 & -2.70113400 \\
\hline $\mathrm{H}$ & 3.09047500 & 0.94742400 & -2.78888000 \\
\hline $\mathrm{C}$ & 3.46969700 & -1.49040500 & 0.18858400 \\
\hline $\mathrm{H}$ & 2.84320200 & -1.99102700 & 0.94540700 \\
\hline $\mathrm{C}$ & 4.88820700 & -1.36771600 & 0.72995900 \\
\hline $\mathrm{H}$ & 5.55657800 & -0.90471600 & -0.00825200 \\
\hline $\mathrm{H}$ & 5.29404400 & -2.36332800 & 0.95297300 \\
\hline $\mathrm{H}$ & 4.93920100 & -0.77454100 & 1.65130800 \\
\hline $\mathrm{C}$ & 3.42522200 & -2.34026500 & -1.07886000 \\
\hline $\mathrm{H}$ & 2.41364300 & -2.39093500 & -1.49878100 \\
\hline $\mathrm{H}$ & 3.75512900 & -3.36313800 & -0.85458400 \\
\hline $\mathrm{H}$ & 4.09720100 & -1.94954300 & -1.85294100 \\
\hline $\mathrm{C}$ & -3.78992500 & 1.33080900 & -0.76650700 \\
\hline $\mathrm{H}$ & -4.73156100 & 1.24841200 & -0.20063100 \\
\hline $\mathrm{C}$ & -3.26627800 & 2.75885900 & -0.64350200 \\
\hline $\mathrm{H}$ & -3.16860600 & 3.08470000 & 0.39866800 \\
\hline $\mathrm{H}$ & -3.95873800 & 3.45279700 & -1.13729500 \\
\hline $\mathrm{H}$ & -2.28605000 & 2.86230100 & -1.12936200 \\
\hline $\mathrm{C}$ & -4.03785100 & 0.98319400 & -2.23048000 \\
\hline $\mathrm{H}$ & -3.09105300 & 0.94759700 & -2.78807600 \\
\hline $\mathrm{H}$ & -4.67199400 & 1.74641900 & -2.69981000 \\
\hline $\mathrm{H}$ & -4.53937100 & 0.01741900 & -2.35547600 \\
\hline $\mathrm{C}$ & -3.47021500 & -1.49064500 & 0.18742100 \\
\hline $\mathrm{H}$ & -2.84421100 & -1.99191100 & 0.94422100 \\
\hline $\mathrm{C}$ & -4.88895000 & -1.36799500 & 0.72813900 \\
\hline $\mathrm{H}$ & -5.29505900 & -2.36363600 & 0.95052100 \\
\hline $\mathrm{H}$ & -5.55698900 & -0.90453500 & -0.01008700 \\
\hline $\mathrm{H}$ & -4.94024700 & -0.77523500 & 1.64974800 \\
\hline $\mathrm{C}$ & -3.42500700 & -2.33965900 & -1.08057800 \\
\hline $\mathrm{H}$ & -4.09499600 & -1.94736400 & -1.85558500 \\
\hline $\mathrm{H}$ & -3.75684200 & -3.36218700 & -0.85756500 \\
\hline $\mathrm{H}$ & -2.41277700 & -2.39153300 & -1.49876300 \\
\hline
\end{tabular}

Evaluating Different Functionals for CO Loss from 5-THF and 9

\begin{tabular}{llrr} 
CO M06L & \multicolumn{3}{c}{$\mathrm{G}_{\mathrm{THF}}=-71103.67418 \mathrm{kcal} / \mathrm{mol}$} \\
$\mathrm{O}$ & 0.00000000 & 0.00000000 & 0.48898900 \\
$\mathrm{C}$ & 0.00000000 & 0.00000000 & -0.65198500
\end{tabular}




\begin{tabular}{|c|c|c|c|}
\hline \multicolumn{4}{|c|}{$\left[\left({ }^{\left({ }^{\mathrm{Pr}} \mathrm{PN}\right.}{ }^{\mathrm{H}} \mathrm{P}\right) \mathrm{Fe}(\mathrm{H})(\mathrm{CO})(\mathrm{THF})\right]^{+}(\mathbf{5}-\mathbf{T H F}) \mathbf{M 0 6 L} \quad \mathrm{G}_{\mathrm{THF}}=-1153719.326 \mathrm{kcal} / \mathrm{mol}$} \\
\hline $\mathrm{Fe}$ & 0.03354800 & -0.23564200 & -0.03941700 \\
\hline $\mathrm{P}$ & 2.25982400 & -0.32572800 & 0.16911300 \\
\hline $\mathrm{P}$ & -2.17606100 & -0.51357300 & 0.12440100 \\
\hline $\mathrm{O}$ & 0.06109800 & -0.12631700 & -2.92702500 \\
\hline $\mathrm{N}$ & 0.02263000 & -0.49680400 & 2.06119000 \\
\hline $\mathrm{H}$ & -0.03235100 & 0.44402500 & 2.45369900 \\
\hline $\mathrm{C}$ & 3.13753100 & -1.81097700 & -0.52441200 \\
\hline $\mathrm{C}$ & -2.60282700 & -3.28855100 & 0.21943900 \\
\hline $\mathrm{H}$ & -1.51950500 & -3.44413300 & 0.29527000 \\
\hline $\mathrm{H}$ & -3.02601800 & -4.17511900 & -0.26265300 \\
\hline $\mathrm{H}$ & -3.01660300 & -3.23865600 & 1.23009200 \\
\hline $\mathrm{C}$ & 3.29566100 & 1.14221800 & -0.30525000 \\
\hline $\mathrm{C}$ & -3.32610800 & 0.87048400 & -0.34449100 \\
\hline $\mathrm{H}$ & -2.83190000 & 1.75478000 & 0.08688900 \\
\hline $\mathrm{C}$ & -1.16348600 & -1.23990100 & 2.55376700 \\
\hline $\mathrm{C}$ & 2.93098500 & -3.04885400 & 0.34044400 \\
\hline $\mathrm{C}$ & 0.04779300 & -0.16049300 & -1.75428400 \\
\hline $\mathrm{C}$ & -4.71780500 & 0.74553300 & 0.26542200 \\
\hline $\mathrm{H}$ & -4.69898400 & 0.69966000 & 1.35727800 \\
\hline $\mathrm{C}$ & 4.66636800 & 1.16149800 & 0.36294000 \\
\hline $\mathrm{C}$ & 2.67364400 & -2.09983200 & -1.94888900 \\
\hline $\mathrm{C}$ & -2.90923000 & -2.05309000 & -0.61917600 \\
\hline $\mathrm{H}$ & -3.99747800 & -1.89499100 & -0.63463900 \\
\hline $\mathrm{C}$ & -3.40379400 & 1.05795500 & -1.85591700 \\
\hline $\mathrm{C}$ & 3.42795800 & 1.28003000 & -1.81846600 \\
\hline $\mathrm{C}$ & 1.26889900 & -1.10310400 & 2.59064300 \\
\hline $\mathrm{C}$ & 2.47181600 & -0.40006500 & 2.00123800 \\
\hline $\mathrm{C}$ & -2.40755200 & -2.26836200 & -2.04373500 \\
\hline $\mathrm{C}$ & -2.42569900 & -0.66288600 & 1.94930500 \\
\hline $\mathrm{H}$ & 0.09411800 & -1.73674800 & -0.13176800 \\
\hline $\mathrm{H}$ & -2.41800500 & 1.06801800 & -2.33269100 \\
\hline $\mathrm{H}$ & -3.90011100 & 2.00383900 & -2.09312700 \\
\hline $\mathrm{H}$ & -3.99195100 & 0.26002500 & -2.32118700 \\
\hline $\mathrm{H}$ & -5.32764400 & 1.60958200 & -0.01676900 \\
\hline $\mathrm{H}$ & -5.23681700 & -0.14701400 & -0.10011900 \\
\hline $\mathrm{H}$ & -2.54786800 & -1.40051700 & -2.69246300 \\
\hline $\mathrm{H}$ & -2.60965700 & 0.34489600 & 2.34340500 \\
\hline $\mathrm{H}$ & -3.30358400 & -1.26281400 & 2.20922300 \\
\hline $\mathrm{H}$ & -1.19609300 & -1.21875300 & 3.65054400 \\
\hline $\mathrm{H}$ & -1.02589300 & -2.28174600 & 2.24665300 \\
\hline $\mathrm{H}$ & 1.27394100 & -1.06171900 & 3.68730000 \\
\hline $\mathrm{H}$ & 1.25041600 & -2.15832900 & 2.30001700 \\
\hline $\mathrm{H}$ & 2.51961100 & 0.63546000 & 2.36178200 \\
\hline $\mathrm{H}$ & 3.40654300 & -0.88346100 & 2.30256600 \\
\hline $\mathrm{H}$ & 3.31843500 & -2.93434700 & 1.35640300 \\
\hline $\mathrm{H}$ & 1.86557000 & -3.30340900 & 0.40184200 \\
\hline $\mathrm{H}$ & 3.44403800 & -3.90397400 & -0.11022300 \\
\hline $\mathrm{H}$ & 3.26531800 & -2.91596900 & -2.37511600 \\
\hline $\mathrm{H}$ & 4.20791500 & -1.55798300 & -0.53222300 \\
\hline
\end{tabular}




$\begin{array}{lrrr}\mathrm{H} & 1.62340200 & -2.41175500 & -1.94491400 \\ \mathrm{H} & 2.76001100 & -1.24033400 & -2.61795200 \\ \mathrm{H} & 4.60611000 & 1.16500700 & 1.45414700 \\ \mathrm{H} & 5.27253700 & 0.30003300 & 0.06192500 \\ \mathrm{H} & 4.11000400 & 0.52448300 & -2.22289500 \\ \mathrm{H} & 5.21437300 & 2.06005100 & 0.06190300 \\ \mathrm{H} & 3.84484800 & 2.25907700 & -2.07349200 \\ \mathrm{H} & 2.47149600 & 1.17654700 & -2.34164800 \\ \mathrm{H} & 2.70348000 & 1.98735700 & 0.07723100 \\ \mathrm{H} & -2.93259400 & -3.11416600 & -2.49839200 \\ \mathrm{H} & -1.33787800 & -2.50423400 & -2.03331500 \\ \mathrm{O} & 0.01732300 & 1.91248000 & 0.27340800 \\ \mathrm{C} & 0.00983600 & 2.76331100 & -0.89743200 \\ \mathrm{C} & -0.47798000 & 2.65354800 & 1.41317800 \\ \mathrm{C} & 0.01309500 & 4.16919400 & -0.34670400 \\ \mathrm{H} & 0.88704700 & 2.49752100 & -1.49409900 \\ \mathrm{H} & -0.89412200 & 2.54957300 & -1.48668700 \\ \mathrm{C} & -0.87846700 & 4.01752700 & 0.88059300 \\ \mathrm{H} & -1.31805900 & 2.10158200 & 1.85457000 \\ \mathrm{H} & 0.33304600 & 2.71715100 & 2.15075000 \\ \mathrm{H} & -0.36225200 & 4.90036100 & -1.06430700 \\ \mathrm{H} & 1.02772700 & 4.46213600 & -0.05626400 \\ \mathrm{H} & -1.93307300 & 4.01750300 & 0.58394200 \\ \mathrm{H} & -0.73984000 & 4.80492600 & 1.62299200\end{array}$

\footnotetext{
$\left[\left({ }^{\mathrm{iPr} P N}{ }^{\mathrm{H}} \mathrm{P}\right) \mathrm{Fe}(\mathrm{H})(\mathrm{THF})\right]^{+}($5-THF no CO singlet $)$M06L G $\mathrm{THF}_{\mathrm{THF}}=-1082570.244 \mathrm{kcal} / \mathrm{mol}$

$\mathrm{Fe} \quad 0.01638500 \quad-0.25084900-0.10745600$

$\mathrm{P} \quad 2.25351300 \quad-0.40287700 \quad 0.01715100$

$\mathrm{P} \quad-2.21521300 \quad-0.44456300 \quad-0.00670300$

$\begin{array}{llll}\mathrm{N} & 0.01065200 & -0.62225600 & 1.90957700\end{array}$

$\begin{array}{llll}\mathrm{H} & 0.00105600 & 0.27766600 & 2.39463800\end{array}$

C $\quad 3.10151500 \quad-1.82889900-0.82791700$

C $\quad-2.75509600 \quad-3.20470900-0.11362000$

$\mathrm{H} \quad-1.67881800 \quad-3.40140600-0.03711200$

$\mathrm{H} \quad-3.20483400-4.04063000-0.65901600$

$\mathrm{H} \quad-3.17819800 \quad-3.20658000 \quad 0.89501200$

$\begin{array}{lllll}\text { C } & 3.36004500 & 1.06551000 & -0.29248900\end{array}$

$\begin{array}{lllll}\mathrm{C} & & -3.38917700 & 0.96821800 & -0.34329400\end{array}$

$\begin{array}{llll}\mathrm{H} & -2.87680400 & 1.83275300 & 0.10688500\end{array}$

$\begin{array}{llll}\text { C } & -1.19802000 & -1.36540800 & 2.35096000\end{array}$

$\begin{array}{llll}\text { C } & 2.86080200 & -3.14295000 & -0.09544300\end{array}$

$\begin{array}{llll}\text { C } & -4.75272700 & 0.81336200 & 0.32042300\end{array}$

$\begin{array}{llll}\mathrm{H} & -4.68609500 & 0.73466100 & 1.40852300\end{array}$

$\begin{array}{llll}\mathrm{C} & 4.73375100 & 0.95588900 & 0.35881600\end{array}$

$\begin{array}{llll}\mathrm{C} & 2.59938700 & -1.94020400 & -2.26533700\end{array}$

C $\quad-3.00360500 \quad-1.90141000 \quad-0.86208800$

$\mathrm{H} \quad-4.08638400 \quad-1.71071800 \quad-0.89579600$

$\begin{array}{lllll}\mathrm{C} & -3.54295900 & 1.22690600 & -1.83819000\end{array}$

$\begin{array}{llll}\mathrm{C} & 3.49147300 & 1.37570900 & -1.77952800\end{array}$

$\begin{array}{llll}\text { C } & 1.22842100 & -1.34387100 & 2.36193400\end{array}$

$\begin{array}{llll}\text { C } & 2.47031400 & -0.65942900 & 1.83423800\end{array}$
} 


\begin{tabular}{|c|c|c|c|}
\hline $\mathrm{C}$ & -2.46188500 & -2.01442000 & -2.28490500 \\
\hline $\mathrm{C}$ & -2.44836200 & -0.70872500 & 1.80777700 \\
\hline $\mathrm{H}$ & 0.02398700 & -1.76363800 & -0.35236200 \\
\hline $\mathrm{H}$ & -2.58186700 & 1.26366200 & -2.36258100 \\
\hline $\mathrm{H}$ & -4.05522600 & 2.17863000 & -2.01087600 \\
\hline $\mathrm{H}$ & -4.14831900 & 0.44552900 & -2.31044200 \\
\hline $\mathrm{H}$ & -5.38449200 & 1.67804000 & 0.09159800 \\
\hline $\mathrm{H}$ & -5.27841300 & -0.07476600 & -0.04768700 \\
\hline $\mathrm{H}$ & -2.62668200 & -1.11308700 & -2.88091400 \\
\hline $\mathrm{H}$ & -2.58785200 & 0.27923700 & 2.26608300 \\
\hline $\mathrm{H}$ & -3.34050300 & -1.29514200 & 2.05026500 \\
\hline $\mathrm{H}$ & -1.21629300 & -1.43396700 & 3.44666300 \\
\hline $\mathrm{H}$ & -1.09313200 & -2.38069300 & 1.95479100 \\
\hline $\mathrm{H}$ & 1.23551500 & -1.41564800 & 3.45760600 \\
\hline $\mathrm{H}$ & 1.14718900 & -2.35976800 & 1.96127800 \\
\hline $\mathrm{H}$ & 2.57905700 & 0.33283500 & 2.29085400 \\
\hline $\mathrm{H}$ & 3.37258700 & -1.22483300 & 2.08853800 \\
\hline $\mathrm{H}$ & 3.26040600 & -3.14413500 & 0.92275000 \\
\hline $\mathrm{H}$ & 1.78687100 & -3.36019000 & -0.04451100 \\
\hline $\mathrm{H}$ & 3.33857000 & -3.96634600 & -0.63603400 \\
\hline $\mathrm{H}$ & 3.10220500 & -2.76393800 & -2.78265500 \\
\hline $\mathrm{H}$ & 4.18007900 & -1.61360800 & -0.83075800 \\
\hline $\mathrm{H}$ & 1.52263600 & -2.14712500 & -2.26633200 \\
\hline $\mathrm{H}$ & 2.76545900 & -1.03149000 & -2.84978100 \\
\hline $\mathrm{H}$ & 4.67826500 & 0.82953100 & 1.44314100 \\
\hline $\mathrm{H}$ & 5.30378400 & 0.11292600 & -0.04753800 \\
\hline $\mathrm{H}$ & 4.14489700 & 0.65016700 & -2.27647500 \\
\hline $\mathrm{H}$ & 5.31792900 & 1.86144100 & 0.16350000 \\
\hline $\mathrm{H}$ & 3.93784600 & 2.36441900 & -1.92646000 \\
\hline $\mathrm{H}$ & 2.52854200 & 1.36298700 & -2.30124700 \\
\hline $\mathrm{H}$ & 2.80432900 & 1.88627700 & 0.18502700 \\
\hline $\mathrm{H}$ & -2.93789000 & -2.85007400 & -2.80847200 \\
\hline $\mathrm{H}$ & -1.38250800 & -2.20380100 & -2.25538200 \\
\hline $\mathrm{O}$ & 0.07655800 & 1.87813800 & 0.08761400 \\
\hline $\mathrm{C}$ & -0.04993600 & 2.72885600 & -1.06794800 \\
\hline $\mathrm{C}$ & -0.22184800 & 2.63459300 & 1.28015400 \\
\hline $\mathrm{C}$ & 0.24644300 & 4.11122700 & -0.53621300 \\
\hline $\mathrm{H}$ & 0.65177400 & 2.35579900 & -1.81923600 \\
\hline $\mathrm{H}$ & -1.07149100 & 2.65505100 & -1.47017300 \\
\hline $\mathrm{C}$ & -0.45287000 & 4.06729600 & 0.82005100 \\
\hline $\mathrm{H}$ & -1.10119300 & 2.19393000 & 1.77089900 \\
\hline $\mathrm{H}$ & 0.64089800 & 2.54005300 & 1.95234700 \\
\hline $\mathrm{H}$ & -0.12829700 & 4.90355400 & -1.18621900 \\
\hline $\mathrm{H}$ & 1.32716000 & 4.24569700 & -0.41700800 \\
\hline $\mathrm{H}$ & -1.52348600 & 4.25985900 & 0.69671100 \\
\hline $\mathrm{H}$ & -0.06378300 & 4.79597800 & 1.53287300 \\
\hline
\end{tabular}

$\left[\left({ }^{i \mathrm{Pr}} \mathrm{PN}{ }^{\mathrm{H}} \mathrm{P}\right) \mathrm{Fe}(\mathrm{H})(\mathrm{THF})\right]^{+}\left(\right.$5-THF no CO triplet) $\mathbf{M 0 6 L} \mathrm{G}_{\mathrm{THF}}=-1082578.516 \mathrm{kcal} / \mathrm{mol}$ $\begin{array}{cccc}\mathrm{Fe} & 0.01566700 & -0.17574000 & -0.13749900 \\ \mathrm{P} & 2.26970800 & -0.44021000 & 0.01450200 \\ \mathrm{P} & -2.21991800 & -0.41544000 & -0.00412400\end{array}$ 


\begin{tabular}{|c|c|c|c|}
\hline $\mathrm{N}$ & 0.02113300 & -0.78734100 & 2.08097000 \\
\hline $\mathrm{H}$ & 0.05913500 & 0.01227200 & 2.71133500 \\
\hline $\mathrm{C}$ & 3.05390700 & -1.80350100 & -0.97927200 \\
\hline $\mathrm{C}$ & -2.77409800 & -3.17155400 & -0.23374000 \\
\hline $\mathrm{H}$ & -1.69901500 & -3.38512800 & -0.18668600 \\
\hline $\mathrm{H}$ & -3.24151600 & -3.97473400 & -0.81224300 \\
\hline $\mathrm{H}$ & -3.17925000 & -3.21981100 & 0.78091700 \\
\hline $\mathrm{C}$ & 3.41263500 & 1.02232600 & -0.12675900 \\
\hline $\mathrm{C}$ & -3.41069500 & 1.00475500 & -0.24508600 \\
\hline $\mathrm{H}$ & -2.88833300 & 1.85627800 & 0.21835500 \\
\hline $\mathrm{C}$ & -1.22334400 & -1.53008500 & 2.34902000 \\
\hline $\mathrm{C}$ & 2.72859500 & -3.17462300 & -0.40005900 \\
\hline $\mathrm{C}$ & -4.75052100 & 0.81866900 & 0.45833100 \\
\hline $\mathrm{H}$ & -4.64870200 & 0.71451400 & 1.54129200 \\
\hline $\mathrm{C}$ & 4.80327700 & 0.78114400 & 0.44817000 \\
\hline $\mathrm{C}$ & 2.56517400 & -1.72188400 & -2.42330000 \\
\hline $\mathrm{C}$ & -3.02381800 & -1.83159000 & -0.91328300 \\
\hline $\mathrm{H}$ & -4.10530900 & -1.63095200 & -0.91305300 \\
\hline $\mathrm{C}$ & -3.61775700 & 1.31391800 & -1.72407800 \\
\hline $\mathrm{C}$ & 3.49122700 & 1.54213600 & -1.55709900 \\
\hline $\mathrm{C}$ & 1.22266100 & -1.61021700 & 2.31205600 \\
\hline $\mathrm{C}$ & 2.46679100 & -0.90441400 & 1.79808600 \\
\hline $\mathrm{C}$ & -2.51832400 & -1.88188200 & -2.35208900 \\
\hline $\mathrm{C}$ & -2.42721300 & -0.77987200 & 1.80377300 \\
\hline $\mathrm{H}$ & -0.09172000 & -1.70400500 & -0.41984000 \\
\hline $\mathrm{H}$ & -2.67643500 & 1.37472300 & -2.28098600 \\
\hline $\mathrm{H}$ & -4.14105000 & 2.26760200 & -1.84436700 \\
\hline $\mathrm{H}$ & -4.23554200 & 0.54565500 & -2.20165700 \\
\hline $\mathrm{H}$ & -5.39599600 & 1.68300600 & 0.27067500 \\
\hline $\mathrm{H}$ & -5.28029800 & -0.06472000 & 0.08459200 \\
\hline $\mathrm{H}$ & -2.67897600 & -0.94873500 & -2.89798100 \\
\hline $\mathrm{H}$ & -2.52396000 & 0.18901500 & 2.31183700 \\
\hline $\mathrm{H}$ & -3.35357900 & -1.32858100 & 2.00790700 \\
\hline $\mathrm{H}$ & -1.34756700 & -1.73575100 & 3.42158900 \\
\hline $\mathrm{H}$ & -1.12334600 & -2.49795700 & 1.84560500 \\
\hline $\mathrm{H}$ & 1.33473500 & -1.87029300 & 3.37436600 \\
\hline $\mathrm{H}$ & 1.06715600 & -2.54705800 & 1.76429100 \\
\hline $\mathrm{H}$ & 2.61834000 & 0.03201600 & 2.35097400 \\
\hline $\mathrm{H}$ & 3.35981400 & -1.51489500 & 1.97175900 \\
\hline $\mathrm{H}$ & 3.12069100 & -3.31538100 & 0.61112000 \\
\hline $\mathrm{H}$ & 1.64299500 & -3.33263900 & -0.37317000 \\
\hline $\mathrm{H}$ & 3.15898400 & -3.95851000 & -1.03125400 \\
\hline $\mathrm{H}$ & 3.03054900 & -2.50636400 & -3.02891100 \\
\hline $\mathrm{H}$ & 4.14237900 & -1.65134400 & -0.94886300 \\
\hline $\mathrm{H}$ & 1.47861600 & -1.86928800 & -2.45763100 \\
\hline $\mathrm{H}$ & 2.78433000 & -0.76160700 & -2.89721000 \\
\hline $\mathrm{H}$ & 4.78010600 & 0.48825400 & 1.50116600 \\
\hline $\mathrm{H}$ & 5.33650100 & 0.00057200 & -0.10534800 \\
\hline $\mathrm{H}$ & 4.09121600 & 0.87774400 & -2.18810800 \\
\hline $\mathrm{H}$ & 5.40430200 & 1.69352300 & 0.37458200 \\
\hline $\mathrm{H}$ & 3.96989700 & 2.52618700 & -1.58022000 \\
\hline
\end{tabular}




$\begin{array}{lrrr}\mathrm{H} & 2.50284300 & 1.63801900 & -2.01895000 \\ \mathrm{H} & 2.90171000 & 1.78096700 & 0.48378200 \\ \mathrm{H} & -3.02324300 & -2.68180500 & -2.90346900 \\ \mathrm{H} & -1.44234400 & -2.09172300 & -2.36159600 \\ \mathrm{O} & 0.19709000 & 1.92238400 & 0.03815700 \\ \mathrm{C} & -0.12398600 & 2.80052200 & -1.05978600 \\ \mathrm{C} & -0.06614800 & 2.61046200 & 1.28464600 \\ \mathrm{C} & 0.22436600 & 4.16623200 & -0.51921600 \\ \mathrm{H} & 0.46251700 & 2.46312400 & -1.91840000 \\ \mathrm{H} & -1.19337700 & 2.71528000 & -1.30328800 \\ \mathrm{C} & -0.30510600 & 4.07049000 & 0.91105400 \\ \mathrm{H} & -0.93317200 & 2.14468800 & 1.77375500 \\ \mathrm{H} & 0.81472400 & 2.46170600 & 1.91928700 \\ \mathrm{H} & -0.23186400 & 4.97693600 & -1.08946100 \\ \mathrm{H} & 1.31076500 & 4.30514300 & -0.52858100 \\ \mathrm{H} & -1.37506400 & 4.29869100 & 0.93211300 \\ \mathrm{H} & 0.19275000 & 4.75547500 & 1.59902200\end{array}$

$\left[\left({ }^{\mathrm{iPr} P N}{ }^{\mathrm{H}} \mathrm{P}\right) \mathrm{Fe}(\mathrm{H})(\mathrm{THF})\right]^{+}($5-THF no CO quintet $)$M06L $\mathrm{G}_{\mathrm{THF}}=-1082577.445 \mathrm{kcal} / \mathrm{mol}$ $\mathrm{Fe} \quad-0.08991000 \quad-0.27893100 \quad-0.32697600$

$\begin{array}{llll}\mathrm{P} & 2.47508900 & -0.46982100 & 0.13105900\end{array}$

$\begin{array}{llll}\mathrm{P} & -2.62759000 & -0.34974800 & 0.11855300\end{array}$

$\mathrm{N} \quad-0.13758300 \quad-1.63740400 \quad 1.44180200$

$\mathrm{H} \quad-0.12074100-1.03861400 \quad 2.26889000$

C $\quad 3.41627900-1.36513400-1.21097600$

C $\quad-3.25168600 \quad-2.56306200-1.46125300$

$\mathrm{H} \quad-2.21487600-2.54708200 \quad-1.81752500$

$\mathrm{H} \quad-3.86977800 \quad-2.99710100 \quad-2.25388300$

$\mathrm{H} \quad-3.30951800 \quad-3.23724300 \quad-0.60159500$

$\begin{array}{llll}\mathrm{C} & 3.73040300 & 0.73226400 & 0.82647100\end{array}$

$\begin{array}{llll}\text { C } & -3.60163600 & 1.05992300 & 0.85727300\end{array}$

$\begin{array}{llll}\mathrm{H} & -3.04513800 & 1.24941300 & 1.78772800\end{array}$

$\begin{array}{llll}\text { C } & -1.37649800 & -2.44292200 & 1.48616500\end{array}$

$\begin{array}{llll}\text { C } & 2.98353000 & -2.82092800 & -1.34015000\end{array}$

$\begin{array}{llll}\text { C } & -5.03662500 & 0.70492500 & 1.22780800\end{array}$

$\begin{array}{llll}\mathrm{H} & -5.10105000 & -0.19538700 & 1.84669500\end{array}$

$\begin{array}{llll}\mathrm{C} & 4.89079500 & 0.06519400 & 1.55793300\end{array}$

$\begin{array}{llll}\text { C } & 3.21140100 & -0.64641600 & -2.54323000\end{array}$

$\begin{array}{llll}\mathrm{C} & -3.74250400 & -1.15602200 & -1.13505100\end{array}$

$\begin{array}{llll}\mathrm{H} & -4.74063600 & -1.23035900 & -0.68109600\end{array}$

$\begin{array}{llll}\text { C } & -3.53867600 & 2.32727400 & 0.00763500\end{array}$

$\begin{array}{llll}\text { C } & 4.25968300 & 1.66937600 & -0.25390400\end{array}$

$\begin{array}{llll}\mathrm{C} & 1.06092100 & -2.50147100 & 1.47961900\end{array}$

$\begin{array}{llll}\mathrm{C} & 2.33572400 & -1.67843900 & 1.53012800\end{array}$

$\begin{array}{llll}\text { C } & -3.82392400 & -0.30686100 & -2.39898900\end{array}$

$\begin{array}{llll}\mathrm{C} & -2.61316700 & -1.55983000 & 1.52241200\end{array}$

$\mathrm{H} \quad-0.05674300 \quad-1.14377300 \quad-1.75811100$

$\begin{array}{llll}\mathrm{H} & -2.53122100 & 2.52062900 & -0.37385300\end{array}$

$\begin{array}{llll}\mathrm{H} & -3.85285700 & 3.19465500 & 0.59765900\end{array}$

$\mathrm{H} \quad-4.21193700 \quad 2.26548800 \quad-0.85260100$

$\mathrm{H} \quad \begin{array}{llll}\mathrm{H} & -5.49564000 & 1.52547100 & 1.78926300\end{array}$ 


$\begin{array}{lrrr}\mathrm{H} & -5.64925500 & 0.54472900 & 0.33423600 \\ \mathrm{H} & -4.25664600 & 0.68032100 & -2.21677400 \\ \mathrm{H} & -2.62508100 & -0.97979500 & 2.45393700 \\ \mathrm{H} & -3.51514000 & -2.18180600 & 1.53209000 \\ \mathrm{H} & -1.35869000 & -3.11452000 & 2.35553400 \\ \mathrm{H} & -1.36991700 & -3.07739100 & 0.59186100 \\ \mathrm{H} & 1.01205300 & -3.17645700 & 2.34548500 \\ \mathrm{H} & 1.02772200 & -3.12986500 & 0.58208500 \\ \mathrm{H} & 2.34676800 & -1.08475700 & 2.45359700 \\ \mathrm{H} & 3.20672300 & -2.34066400 & 1.58021600 \\ \mathrm{H} & 3.17813900 & -3.40657800 & -0.43706200 \\ \mathrm{H} & 1.91434600 & -2.88621400 & -1.57444300 \\ \mathrm{H} & 3.52798600 & -3.29775000 & -2.16173700 \\ \mathrm{H} & 3.79101900 & -1.13784000 & -3.33187400 \\ \mathrm{H} & 4.48122200 & -1.33428700 & -0.93651900 \\ \mathrm{H} & 2.15346000 & -0.68268500 & -2.82751300 \\ \mathrm{H} & 3.51557500 & 0.40344600 & -2.51647200 \\ \mathrm{H} & 4.56873900 & -0.52131700 & 2.42163100 \\ \mathrm{H} & 5.45645600 & -0.59714800 & 0.89268700 \\ \mathrm{H} & 4.94004900 & 1.14172400 & -0.93107900 \\ \mathrm{H} & 5.58831100 & 0.82749200 & 1.92105900 \\ \mathrm{H} & 4.82631400 & 2.48807800 & 0.20051200 \\ \mathrm{H} & 3.46473500 & 2.11152700 & -0.86277800 \\ \mathrm{H} & 3.15347200 & 1.32569400 & 1.55077800 \\ \mathrm{H} & -4.44712200 & -0.80447700 & -3.14906400 \\ \mathrm{H} & -2.82971100 & -0.16247700 & -2.83788400 \\ \mathrm{O} & -0.06915600 & 1.85040300 & -0.29686400 \\ \mathrm{C} & 0.62110700 & 2.66690200 & -1.28634500 \\ \mathrm{C} & -0.05138800 & 2.51865500 & 0.99028400 \\ \mathrm{C} & 1.11936700 & 3.88512700 & -0.52907000 \\ \mathrm{H} & 1.41570000 & 2.05702300 & -1.73408800 \\ \mathrm{H} & -0.11191300 & 2.91488500 & -2.06132600 \\ \mathrm{C} & 0.15463500 & 3.97543400 & 0.64966900 \\ \mathrm{H} & -0.99983000 & 2.28613200 & 1.48487600 \\ \mathrm{H} & 0.77404900 & 2.10758200 & 1.59076800 \\ \mathrm{H} & 1.12481100 & 4.78081000 & -1.15252200 \\ \mathrm{H} & 2.14007400 & 3.72319600 & -0.16539100 \\ \mathrm{H} & -0.79382500 & 4.43095100 & 0.34533700 \\ \mathrm{H} & 0.55459500 & 4.54676300 & 1.48916700 \\ & & & \end{array}$

$\left({ }^{(\mathrm{PP} P N}{ }^{\mathrm{H}} \mathrm{P}\right) \mathrm{Fe}(\mathrm{H})(\mathrm{CO})\left(\mathrm{OCH}_{3}\right)(\mathbf{9}) \mathbf{M 0 6 L} \quad \mathrm{G}_{\mathrm{THF}}=-1080223.904 \mathrm{kcal} / \mathrm{mol}$ Fe $\quad-0.06502800 \quad-0.00591500 \quad 0.12408600$

$\begin{array}{llll}\mathrm{H} & -0.08481400 & -1.45361100 & 0.63554900\end{array}$

$\begin{array}{llll}\mathrm{P} & 2.16051800 & -0.08190600 & -0.00110100\end{array}$

$\begin{array}{llll}\mathrm{P} & -2.26551000 & -0.12356800 & -0.14905300\end{array}$

$\begin{array}{llll}\mathrm{O} & -0.09555100 & 0.81413600 & 2.88713300\end{array}$

$\mathrm{N} \quad \begin{array}{llll}0.01463500 & -0.92478500 & -1.79571500\end{array}$

$\mathrm{H} \quad 0.05327400 \quad-0.15603000 \quad-2.46632400$

$\begin{array}{llll}\text { C } & -0.09520600 & 0.51249400 & 1.74729300\end{array}$

$\begin{array}{llll}\mathrm{C} & 2.45293000 & -0.87439500 & -1.64781600\end{array}$

$\begin{array}{llll}\mathrm{H} & 2.55389300 & -0.07511400 & -2.39224700\end{array}$ 


$\begin{array}{lrrr}\mathrm{H} & 3.37771500 & -1.46147000 & -1.68210300 \\ \mathrm{C} & 1.24208200 & -1.72642600 & -1.97743600 \\ \mathrm{H} & 1.29807400 & -2.12082800 & -3.00243100 \\ \mathrm{H} & 1.16443200 & -2.58001200 & -1.29460400 \\ \mathrm{C} & -1.19698400 & -1.71262900 & -2.10246800 \\ \mathrm{H} & -1.17328100 & -2.59039300 & -1.44684200 \\ \mathrm{H} & -1.17046100 & -2.07196300 & -3.14137500 \\ \mathrm{C} & -2.43220600 & -0.87371400 & -1.83636100 \\ \mathrm{H} & -3.34585600 & -1.46899000 & -1.94374500 \\ \mathrm{H} & -2.49447000 & -0.05336500 & -2.56290600 \\ \mathrm{C} & 3.12198300 & -1.12035500 & 1.20940200 \\ \mathrm{H} & 2.82407400 & -0.72238100 & 2.19051900 \\ \mathrm{C} & 4.63786000 & -1.02751800 & 1.07752700 \\ \mathrm{H} & 4.97155800 & -1.29143300 & 0.06690100 \\ \mathrm{H} & 5.11657100 & -1.73088700 & 1.76761600 \\ \mathrm{H} & 5.02297800 & -0.03171800 & 1.30751100 \\ \mathrm{C} & 2.67534500 & -2.57659800 & 1.12805200 \\ \mathrm{H} & 1.58736500 & -2.67374900 & 1.18374500 \\ \mathrm{H} & 3.12043200 & -3.15406100 & 1.94467000 \\ \mathrm{H} & 3.01119600 & -3.03662200 & 0.19061000 \\ \mathrm{C} & 2.97095200 & 1.58422500 & -0.09229000 \\ \mathrm{H} & 2.17948000 & 2.14183400 & -0.61199800 \\ \mathrm{C} & 4.26684800 & 1.70159300 & -0.88544400 \\ \mathrm{H} & 5.11078600 & 1.20871600 & -0.39536400 \\ \mathrm{H} & 4.53245700 & 2.75894800 & -0.99681700 \\ \mathrm{H} & 4.18075800 & 1.28538400 & -1.89359500 \\ \mathrm{C} & 3.08842900 & 2.18654500 & 1.30445000 \\ \mathrm{H} & 2.13321900 & 2.15452000 & 1.83780400 \\ \mathrm{H} & 3.39798700 & 3.23486900 & 1.23995300 \\ \mathrm{H} & -3.83267500 & 1.66785800 & 1.91936800 \\ \mathrm{H} & -3.34149300 & -1.22886300 & 0.89268700 \\ \mathrm{C} & -1.73461100 & 2.5971500 \\ \mathrm{H} & -4.35763900 & -1.13306700 & 0.48346400 \\ \mathrm{C} & -2.91446900 & -2.68665200 & 0.77187000 \\ \mathrm{H} & -3.03425000 & -3.07437300 & -0.24433600 \\ \mathrm{H} & -3.52531900 & -3.31184000 & 1.43179600 \\ \mathrm{H} & -1.86477700 & -2.81288000 & 1.06045700 \\ \mathrm{C} & -3.34995100 & -0.78686400 & 2.35056200 \\ \mathrm{H} & -2.34085400 & -0.81209900 & 2.77508700 \\ \mathrm{H} & -3.97737900 & -1.45812400 & 2.94658000 \\ \mathrm{H} & -3.74054300 & 0.22673400 & 2.47934600 \\ \mathrm{H} & -3.18566900 & 1.48348700 & -0.30740700 \\ \mathrm{H} & -2.76190400 & 1.88778800 & -1.23766300 \\ \mathrm{H} & -5.14714000 & 1.32848300 & -0.47320600 \\ \mathrm{H} & 2.29216300 & -0.72546200 \\ \mathrm{H} & -2.95855400 & 0.62010200 & -1.26498700 \\ \mathrm{H} & & 1.89157100 & -0.68859900\end{array}$




$\begin{array}{lrrr}\mathrm{C} & -0.02591300 & 2.07593900 & -2.03380800 \\ \mathrm{H} & -0.05761000 & 3.15021800 & -2.30673900 \\ \mathrm{H} & 0.90542100 & 1.68854700 & -2.53231200 \\ \mathrm{H} & -0.87196800 & 1.61614600 & -2.61181800\end{array}$

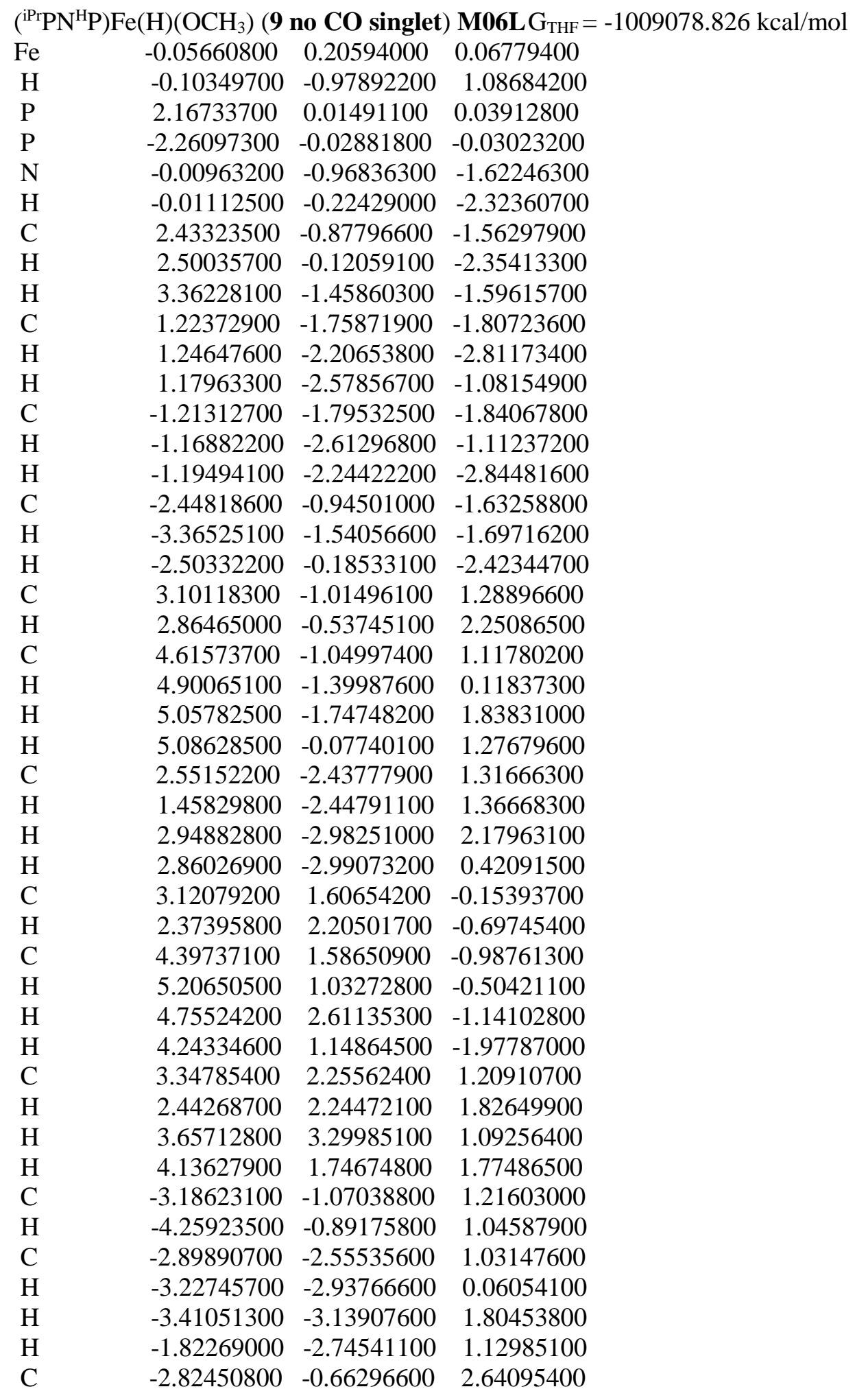




$\begin{array}{lrrr}\mathrm{H} & -1.76293700 & -0.86271500 & 2.82118200 \\ \mathrm{H} & -3.40820800 & -1.24534400 & 3.36278700 \\ \mathrm{H} & -3.00132100 & 0.39553200 & 2.84682500 \\ \mathrm{C} & -3.40534500 & 1.42502400 & -0.31159400 \\ \mathrm{H} & -2.79547300 & 2.07806400 & -0.95362100 \\ \mathrm{C} & -4.70236200 & 1.08118700 & -1.03543100 \\ \mathrm{H} & -5.31800700 & 1.97941000 & -1.15947000 \\ \mathrm{H} & -5.29991200 & 0.36088300 & -0.46368700 \\ \mathrm{H} & -4.53653700 & 0.65952500 & -2.02986300 \\ \mathrm{C} & -3.71427400 & 2.17074900 & 0.98271100 \\ \mathrm{H} & -4.41612200 & 1.60305400 & 1.60450100 \\ \mathrm{H} & -4.18685200 & 3.13443200 & 0.76454600 \\ \mathrm{H} & -2.81985700 & 2.36670200 & 1.58332700 \\ \mathrm{O} & -0.01638100 & 1.91059300 & -1.00840600 \\ \mathrm{C} & -0.10212200 & 2.39520100 & 0.23890600 \\ \mathrm{H} & -1.04598100 & 2.92162000 & 0.48734400 \\ \mathrm{H} & -0.07316900 & 1.57076400 & 1.12758100 \\ \mathrm{H} & 0.74717600 & 3.03047400 & 0.56601000\end{array}$

$\left({ }^{\mathrm{iPr}} \mathrm{PN}{ }^{\mathrm{H}} \mathrm{P}\right) \mathrm{Fe}(\mathrm{H})\left(\mathrm{OCH}_{3}\right)(9$ no CO triplet $)$ M06L G $\mathrm{GHF}_{\mathrm{THF}}=-1009086.614 \mathrm{kcal} / \mathrm{mol}$ $\begin{array}{lllll}\mathrm{Fe} & 0.05254600 & 0.08106900 & -0.31133200\end{array}$

$\mathrm{H} \quad-0.02081700 \quad-1.19039400 \quad-1.27441700$

$\begin{array}{llll}\mathrm{P} & -2.17103200 & -0.03014500 & -0.16450800\end{array}$

$\begin{array}{llll}\mathrm{P} & 2.32099300 & -0.08801800 & -0.03104800\end{array}$

$\begin{array}{llll}\mathrm{N} & -0.03782200 & -0.65306000 & 1.84522900\end{array}$

$\begin{array}{llll}\mathrm{H} & -0.01837800 & 0.20103900 & 2.40187300\end{array}$

$\begin{array}{llll}\text { C } & -2.46979500 & -0.52759500 & 1.60588000\end{array}$

$\begin{array}{llll}\mathrm{H} & -2.55105500 & 0.38860700 & 2.20361200\end{array}$

$\mathrm{H} \quad-3.41421800-1.07032300 \quad 1.73600500$

$\begin{array}{llll}\text { C } & -1.29657300 & -1.35744600 & 2.11204600\end{array}$

$\begin{array}{llll}\mathrm{H} & -1.41893700 & -1.59028200 & 3.18159800\end{array}$

$\begin{array}{llll}\mathrm{H} & -1.24357400 & -2.31539000 & 1.58067500\end{array}$

$\begin{array}{llll}\text { C } & 1.16722900 & -1.43262000 & 2.14803500\end{array}$

$\begin{array}{llll}\mathrm{H} & 1.09442500 & -2.36535900 & 1.57355100\end{array}$

$\begin{array}{llll}\mathrm{H} & 1.21824500 & -1.71600000 & 3.21132000\end{array}$

C $\quad 2.40939600 \quad-0.64792200 \quad 1.74613300$

$\mathrm{H} \quad 3.31411200 \quad-1.23595000 \quad 1.94132000$

$\begin{array}{llll}\mathrm{H} & 2.48304500 & 0.25670300 & 2.36440200\end{array}$

C $\quad-3.14669100 \quad-1.30224300 \quad-1.12732000$

$\mathrm{H} \quad-2.89727100 \quad-1.08253500 \quad-2.17523400$

C $\quad-4.66073700 \quad-1.24866500 \quad-0.95830900$

$\mathrm{H} \quad-4.95408900 \quad-1.33956700 \quad 0.09434800$

$\mathrm{H} \quad-5.12723300 \quad-2.08421400 \quad-1.49241200$

$\mathrm{H} \quad-5.10078700 \quad-0.32820600 \quad-1.34823500$

$\begin{array}{lllll}\text { C } & -2.63679200 & -2.70245700 & -0.80152700\end{array}$

$\mathrm{H} \quad-1.54500700 \quad-2.76015400 \quad-0.85786000$

$\mathrm{H} \quad-3.05893100 \quad-3.43341000 \quad-1.49905500$

$\mathrm{H} \quad-2.94715400 \quad-3.00635600 \quad 0.20563700$

C $\quad-3.05968600 \quad 1.59521800 \quad-0.39207800$

$\begin{array}{llll}\mathrm{H} & -2.29207600 & 2.29723600 & -0.04127600\end{array}$

$\begin{array}{llll}\text { C } & -4.32758800 & 1.83998900 & 0.41713400\end{array}$ 


$\begin{array}{lrrr}\mathrm{H} & -5.15378700 & 1.19025100 & 0.11668900 \\ \mathrm{H} & -4.66264700 & 2.87427800 & 0.27747900 \\ \mathrm{H} & -4.16717300 & 1.69637900 & 1.48987600 \\ \mathrm{C} & -3.25592100 & 1.86926100 & -1.88077000 \\ \mathrm{H} & -2.32449800 & 1.73246300 & -2.44118900 \\ \mathrm{H} & -3.59042900 & 2.89990900 & -2.03844900 \\ \mathrm{H} & -4.01011300 & 1.21221900 & -2.32718000 \\ \mathrm{C} & 3.41044100 & -1.34324500 & -0.87350000 \\ \mathrm{H} & 4.39264100 & -1.29539200 & -0.38102500 \\ \mathrm{C} & 2.84090500 & -2.74401600 & -0.68095800 \\ \mathrm{H} & 2.84628600 & -3.05352700 & 0.36867800 \\ \mathrm{H} & 3.43493000 & -3.47583600 & -1.23888500 \\ \mathrm{H} & 1.80756300 & -2.79892200 & -1.04498600 \\ \mathrm{C} & 3.58103300 & -1.02405500 & -2.35327800 \\ \mathrm{H} & 2.60909000 & -0.94095900 & -2.85397900 \\ \mathrm{H} & 4.14291600 & -1.82006400 & -2.85372700 \\ \mathrm{H} & 4.12255000 & -0.08824400 & -2.51816000 \\ \mathrm{C} & 3.30095700 & 1.49203800 & 0.02039800 \\ \mathrm{H} & 2.81335800 & 2.02054000 & 0.85061700 \\ \mathrm{C} & 4.77812000 & 1.30207700 & 0.33551600 \\ \mathrm{H} & 5.26218900 & 2.27169900 & 0.49598100 \\ \mathrm{H} & 5.30539300 & 0.81476200 & -0.49279300 \\ \mathrm{H} & 4.94273600 & 0.69859400 & 1.23453200 \\ \mathrm{C} & 3.07726200 & 2.33575800 & -1.22918800 \\ \mathrm{H} & 3.50540300 & 1.87381800 & -2.12464200 \\ \mathrm{H} & 3.55646200 & 3.31450900 & -1.11345800 \\ \mathrm{H} & 2.00775900 & 2.49245700 & -1.38816000 \\ \mathrm{O} & 0.25008600 & 1.96658500 & 0.22188900 \\ \mathrm{C} & -0.17656100 & 2.45930000 & 1.42302000 \\ \mathrm{H} & -0.25935800 & 3.56420800 & 1.41970300 \\ \mathrm{H} & -1.17694300 & 2.09008100 & 1.75518700 \\ \mathrm{H} & 0.51383000 & 2.22446100 & 2.27087900\end{array}$

( $\left.{ }^{\mathrm{PPr} P N}{ }^{\mathrm{H}} \mathrm{P}\right) \mathrm{Fe}(\mathrm{H})\left(\mathrm{OCH}_{3}\right)($ 9 no CO quintet $)$ M06L $\quad \mathrm{G}_{\mathrm{THF}}=-1009097.027 \mathrm{kcal} / \mathrm{mol}$

$\begin{array}{llll}\mathrm{Fe} & 0.05994200 & 0.04403900 & -0.60014700\end{array}$

$\mathrm{H} \quad 0.07837600-1.26706000-1.71534100$

$\begin{array}{llll}\mathrm{P} & -2.52940000 & -0.03304900 & -0.13558100\end{array}$

$\begin{array}{llll}\mathrm{P} & 2.60945200 & -0.11137600 & 0.04758900\end{array}$

$\begin{array}{llll}\mathrm{N} & -0.03977400 & -0.97634800 & 1.49154100\end{array}$

$\begin{array}{llll}\mathrm{H} & -0.08120100 & -0.22837700 & 2.18488700\end{array}$

$\begin{array}{llll}\text { C } & -2.50720900 & -0.91833300 & 1.49441600\end{array}$

$\begin{array}{llll}\mathrm{H} & -2.50425300 & -0.15679000 & 2.28541300\end{array}$

$\begin{array}{llll}\mathrm{H} & -3.40821900 & -1.52303500 & 1.65367100\end{array}$

$\begin{array}{llll}\mathrm{C} & -1.26409400 & -1.78355800 & 1.63492600\end{array}$

$\begin{array}{llll}\mathrm{H} & -1.27146900 & -2.30601800 & 2.60424400\end{array}$

$\begin{array}{llll}\mathrm{H} & -1.23094700 & -2.55651800 & 0.85625600\end{array}$

$\begin{array}{llll}\mathrm{C} & 1.16492200 & -1.77518600 & 1.77268600\end{array}$

$\begin{array}{llll}\mathrm{H} & 1.19860300 & -2.57429000 & 1.02077800\end{array}$

$\begin{array}{llll}\mathrm{H} & 1.08380500 & -2.26601100 & 2.75508700\end{array}$

$\begin{array}{llll}\mathrm{C} & 2.41914500 & -0.91780700 & 1.71151000\end{array}$

$\mathrm{H} \quad 3.29747900 \quad-1.52003700 \quad 1.97259800$ 


$\begin{array}{lrrr}\mathrm{H} & 2.35309200 & -0.12170100 & 2.46514600 \\ \mathrm{C} & -3.70213100 & -1.04715200 & -1.17676600 \\ \mathrm{H} & -3.62469100 & -0.59284000 & -2.17470500 \\ \mathrm{C} & -5.16741800 & -1.05681800 & -0.75988600 \\ \mathrm{H} & -5.29164800 & -1.34891100 & 0.28975800 \\ \mathrm{H} & -5.72383800 & -1.78233500 & -1.36490500 \\ \mathrm{H} & -5.64647300 & -0.08432900 & -0.89657100 \\ \mathrm{C} & -3.15866900 & -2.47198800 & -1.26642300 \\ \mathrm{H} & -2.09714900 & -2.49021900 & -1.53591500 \\ \mathrm{H} & -3.71457900 & -3.04361600 & -2.01684400 \\ \mathrm{H} & -3.27716600 & -2.99762300 & -0.31093400 \\ \mathrm{C} & -3.36822700 & 1.58053200 & 0.27152800 \\ \mathrm{H} & -2.55623700 & 2.11858500 & 0.78183600 \\ \mathrm{C} & -4.56494100 & 1.56043300 & 1.21824100 \\ \mathrm{H} & -5.46479100 & 1.16487100 & 0.74165200 \\ \mathrm{H} & -4.79446400 & 2.58261900 & 1.54036000 \\ \mathrm{H} & -4.38110800 & 0.97041100 & 2.12112900 \\ \mathrm{C} & -3.67719100 & 2.33428300 & -1.01803400 \\ \mathrm{H} & -2.79751400 & 2.40280200 & -1.66600000 \\ \mathrm{H} & -4.01376800 & 3.35287400 & -0.79736000 \\ \mathrm{H} & -4.47763600 & 1.84419500 & -1.58513800 \\ \mathrm{C} & 3.91150300 & -1.19845900 & -0.73306800 \\ \mathrm{H} & 4.78912100 & -1.19235800 & -0.06986300 \\ \mathrm{C} & 3.39832200 & -2.63117000 & -0.84098900 \\ \mathrm{H} & 3.21950900 & -3.08518000 & 0.13860000 \\ \mathrm{H} & 4.13396700 & -3.25672600 & -1.35819200 \\ \mathrm{H} & 2.46198600 & -2.67611200 & -1.40964700 \\ \mathrm{C} & 4.31639700 & -0.66424800 & -2.10186100 \\ \mathrm{H} & 3.44415400 & -0.55535600 & -2.75740500 \\ \mathrm{H} & 5.01303200 & -1.35432400 & -2.59027200 \\ \mathrm{H} & 4.81049400 & 0.30958000 & -2.03993100 \\ \mathrm{C} & 3.48848100 & 1.46985100 & 0.50656700 \\ \mathrm{H} & 2.84310000 & 1.85976800 & 1.30868000 \\ \mathrm{C} & 4.89284900 & 1.28149000 & 1.06562200 \\ \mathrm{H} & 5.28649900 & 2.23280100 & 1.44071400 \\ \mathrm{H} & 5.58435300 & 0.93131400 & 0.29069600 \\ \mathrm{H} & 4.92396500 & 0.56150100 & 1.89025300 \\ \mathrm{C} & 3.45845000 & 2.48503100 & -0.63295600 \\ \mathrm{H} & 4.13906900 & 2.20396400 & -1.44330900 \\ \mathrm{H} & 3.77943900 & 3.46884500 & -0.27228100 \\ \mathrm{H} & 2.45135700 & 2.57856700 & -1.05210400 \\ \mathrm{C} & 0.09514700 & 1.94990700 & -0.77002200 \\ \mathrm{H} & 0.04754000 & 2.71709500 & 0.38060400 \\ -0.74711300 & 3.48556600 & 0.33294100 \\ \mathrm{H} & 0.15200400 & 2.12651800 & 1.30258600 \\ \mathrm{H} & & 3.25754800 & 0.56582200\end{array}$

CO B3LYP* $\quad \mathrm{G}_{\mathrm{THF}}=-71110.80645 \mathrm{kcal} / \mathrm{mol}$ $\begin{array}{llll}\mathrm{O} & 0.00000000 & 0.00000000 & 0.48754900\end{array}$ $\begin{array}{llll}\mathrm{C} & 0.00000000 & 0.00000000 & -0.65006500\end{array}$ 


\begin{tabular}{|c|c|c|c|}
\hline \multicolumn{4}{|c|}{ 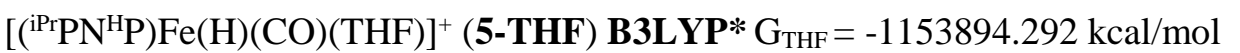 } \\
\hline $\mathrm{Fe}$ & 0.00628600 & -0.25547500 & -0.03095400 \\
\hline $\mathrm{P}$ & 2.24476300 & -0.39849500 & 0.16228600 \\
\hline $\mathrm{P}$ & -2.22783500 & -0.45119900 & 0.13212400 \\
\hline $\mathrm{O}$ & 0.02955300 & -0.26445700 & -2.93113400 \\
\hline $\mathrm{N}$ & -0.00439900 & -0.48418400 & 2.05497900 \\
\hline $\mathrm{H}$ & -0.02319600 & 0.46812700 & 2.41802400 \\
\hline $\mathrm{C}$ & 3.11078300 & -1.91582700 & -0.50262400 \\
\hline $\mathrm{C}$ & -2.75361800 & -3.22557800 & 0.27488100 \\
\hline $\mathrm{H}$ & -1.67699500 & -3.41735600 & 0.32184800 \\
\hline $\mathrm{H}$ & -3.22791500 & -4.09607000 & -0.18976200 \\
\hline $\mathrm{H}$ & -3.14072500 & -3.14647900 & 1.29344700 \\
\hline $\mathrm{C}$ & 3.30167100 & 1.05845300 & -0.33698700 \\
\hline $\mathrm{C}$ & -3.31207100 & 0.99087500 & -0.35331800 \\
\hline $\mathrm{H}$ & -2.79000900 & 1.84294100 & 0.09994700 \\
\hline $\mathrm{C}$ & -1.21813700 & -1.16519100 & 2.58113400 \\
\hline $\mathrm{C}$ & 2.86239000 & -3.15233600 & 0.37151400 \\
\hline $\mathrm{C}$ & 0.01774500 & -0.23425100 & -1.76906800 \\
\hline $\mathrm{C}$ & -4.73192500 & 0.92674000 & 0.22466300 \\
\hline $\mathrm{H}$ & -4.73617800 & 0.84709000 & 1.31441400 \\
\hline $\mathrm{C}$ & 4.68917800 & 1.07385900 & 0.31857100 \\
\hline $\mathrm{C}$ & 2.67944300 & -2.21216700 & -1.94622900 \\
\hline $\mathrm{C}$ & -3.04526300 & -1.97843700 & -0.57049300 \\
\hline $\mathrm{H}$ & -4.12432300 & -1.78526500 & -0.54585200 \\
\hline $\mathrm{C}$ & -3.34710100 & 1.20957300 & -1.87237900 \\
\hline $\mathrm{C}$ & 3.42211800 & 1.19686700 & -1.86152400 \\
\hline $\mathrm{C}$ & 1.22568500 & -1.11517300 & 2.60398900 \\
\hline $\mathrm{C}$ & 2.45749800 & -0.45033000 & 2.00571800 \\
\hline $\mathrm{C}$ & -2.60860800 & -2.22661800 & -2.02129100 \\
\hline $\mathrm{C}$ & -2.47045000 & -0.54890000 & 1.97135000 \\
\hline $\mathrm{H}$ & 0.02243300 & -1.74845700 & -0.12926100 \\
\hline $\mathrm{H}$ & -2.35182300 & 1.18215400 & -2.32233100 \\
\hline $\mathrm{H}$ & -3.79233700 & 2.18457500 & -2.09459700 \\
\hline $\mathrm{H}$ & -3.96168800 & 0.45047900 & -2.36452400 \\
\hline $\mathrm{H}$ & -5.27977400 & 1.83603000 & -0.04443700 \\
\hline $\mathrm{H}$ & -5.28967800 & 0.07724800 & -0.18137300 \\
\hline $\mathrm{H}$ & -2.76135300 & -1.36232200 & -2.66932500 \\
\hline $\mathrm{H}$ & -2.60765100 & 0.47276300 & 2.34193300 \\
\hline $\mathrm{H}$ & -3.36333900 & -1.11296300 & 2.25147300 \\
\hline $\mathrm{H}$ & -1.24132100 & -1.10123200 & 3.67573500 \\
\hline $\mathrm{H}$ & -1.13330800 & -2.21758700 & 2.30621700 \\
\hline $\mathrm{H}$ & 1.23011300 & -1.04122900 & 3.69824300 \\
\hline $\mathrm{H}$ & 1.18657200 & -2.17228700 & 2.33764300 \\
\hline $\mathrm{H}$ & 2.52990600 & 0.58636200 & 2.35243100 \\
\hline $\mathrm{H}$ & 3.37315300 & -0.96000800 & 2.31493400 \\
\hline $\mathrm{H}$ & 3.24282000 & -3.03484800 & 1.38889300 \\
\hline $\mathrm{H}$ & 1.79341800 & -3.38302800 & 0.42002800 \\
\hline $\mathrm{H}$ & 3.36941800 & -4.01589200 & -0.07101400 \\
\hline $\mathrm{H}$ & 3.27170300 & -3.04470500 & -2.33995200 \\
\hline $\mathrm{H}$ & 4.18316800 & -1.68674600 & -0.48556800 \\
\hline
\end{tabular}




$\begin{array}{lrrr}\mathrm{H} & 1.62604200 & -2.50312600 & -1.97168500 \\ \mathrm{H} & 2.81129200 & -1.36164700 & -2.61656600 \\ \mathrm{H} & 4.63622800 & 1.07082700 & 1.40973000 \\ \mathrm{H} & 5.28897600 & 0.21395200 & 0.00405700 \\ \mathrm{H} & 4.09432500 & 0.43737700 & -2.27130200 \\ \mathrm{H} & 5.22872000 & 1.97726600 & 0.01485500 \\ \mathrm{H} & 3.84370300 & 2.17567200 & -2.11108600 \\ \mathrm{H} & 2.46080300 & 1.10344100 & -2.37274900 \\ \mathrm{H} & 2.72325300 & 1.90934400 & 0.04430200 \\ \mathrm{H} & -3.18145500 & -3.06252500 & -2.43590600 \\ \mathrm{H} & -1.54891300 & -2.49221700 & -2.05560900 \\ \mathrm{O} & 0.02126600 & 1.88867400 & 0.21855100 \\ \mathrm{C} & 0.07489100 & 2.76042500 & -0.94163100 \\ \mathrm{C} & -0.26516700 & 2.66545600 & 1.41012700 \\ \mathrm{C} & 0.31472300 & 4.14997700 & -0.37170300 \\ \mathrm{H} & 0.87314900 & 2.39845700 & -1.58758900 \\ \mathrm{H} & -0.87866000 & 2.69478900 & -1.47512600 \\ \mathrm{C} & -0.49658700 & 4.09853500 & 0.92978800 \\ \mathrm{H} & -1.14372900 & 2.24281000 & 1.90475600 \\ \mathrm{H} & 0.59937700 & 2.59311500 & 2.07919600 \\ \mathrm{H} & -0.01490100 & 4.93798100 & -1.05177200 \\ \mathrm{H} & 1.37883700 & 4.29614300 & -0.15960800 \\ \mathrm{H} & -1.55833400 & 4.26192900 & 0.72111700 \\ \mathrm{H} & -0.17609600 & 4.83271000 & 1.67130200\end{array}$

\footnotetext{
$\left[\left({ }^{i \mathrm{Pr}} \mathrm{PN}{ }^{\mathrm{H}} \mathrm{P}\right) \mathrm{Fe}(\mathrm{H})(\mathrm{THF})\right]^{+}\left(\right.$5-THF no CO singlet) $\mathbf{B 3 L Y P} * \mathrm{G}_{\mathrm{THF}}=-1082750.974 \mathrm{kcal} / \mathrm{mol}$

$\mathrm{Fe} \quad-0.06446400-0.23169700 \quad-0.07230800$

$\mathrm{P} \quad 2.17430900 \quad-0.56684500 \quad 0.00830700$

$\mathrm{P} \quad-2.32052700 \quad-0.27503400 \quad 0.01673500$

$\mathrm{N} \quad-0.08462500 \quad-0.64927700 \quad 1.93421200$

$\begin{array}{llll}\mathrm{H} & 0.00238800 & 0.24108300 & 2.42661300\end{array}$

C $\quad 2.84396100 \quad-2.03809600 \quad-0.93404700$

C $\quad-3.07827100-2.99648900-0.10450600$

$\mathrm{H} \quad-2.02147300 \quad-3.27282400 \quad-0.03565100$

$\mathrm{H} \quad-3.59621000-3.78541500-0.66017600$

$\mathrm{H} \quad-3.50000900 \quad-2.97262500 \quad 0.90367400$

$\begin{array}{lllll}\text { C } & 3.44706400 & 0.78385200 & -0.25496900\end{array}$

$\begin{array}{lllll}\mathrm{C} & & -3.31748400 & 1.27067800 & -0.31996400\end{array}$

$\begin{array}{llll}\mathrm{H} & -2.72410100 & 2.04222900 & 0.18736300\end{array}$

$\begin{array}{llll}\text { C } & -1.35865600 & -1.27257300 & 2.38945900\end{array}$

$\begin{array}{llll}\text { C } & 2.49167600 & -3.36870600 & -0.25823900\end{array}$

$\begin{array}{llll}\text { C } & -4.72945100 & 1.25739800 & 0.27825100\end{array}$

$\begin{array}{llll}\mathrm{H} & -4.72083700 & 1.10461900 & 1.36032200\end{array}$

$\begin{array}{llll}\mathrm{C} & 4.83923400 & 0.45867500 & 0.30127600\end{array}$

$\begin{array}{llll}\mathrm{C} & 2.29261500 & -2.01317700 & -2.36827700\end{array}$

C $\quad-3.23660200 \quad-1.66036900 \quad-0.84090700$

$\mathrm{H} \quad-4.29961300 \quad-1.39148700 \quad-0.85683200$

$\begin{array}{llll}\mathrm{C} & -3.35944200 & 1.60508700 & -1.81762500\end{array}$

$\begin{array}{llll}\mathrm{C} & 3.53116700 & 1.21362300 & -1.72560600\end{array}$

$\begin{array}{llll}\mathrm{C} & 1.06731900 & -1.49523900 & 2.35317300\end{array}$

$\begin{array}{llll}\mathrm{C} & 2.37737500 & -0.92764800 & 1.82054800\end{array}$
} 


$\begin{array}{lrrr}\mathrm{C} & -2.72248400 & -1.79516000 & -2.28293200 \\ \mathrm{C} & -2.55766900 & -0.50605700 & 1.84459700 \\ \mathrm{H} & -0.14161100 & -1.72220700 & -0.37280400 \\ \mathrm{H} & -2.37298100 & 1.53775400 & -2.28566300 \\ \mathrm{H} & -3.73540800 & 2.62298900 & -1.96462300 \\ \mathrm{H} & -4.03277000 & 0.92835100 & -2.35226600 \\ \mathrm{H} & -5.22704900 & 2.21351000 & 0.08154300 \\ \mathrm{H} & -5.34502400 & 0.47088900 & -0.17007800 \\ \mathrm{H} & -2.84390400 & -0.87732800 & -2.86193300 \\ \mathrm{H} & -2.59810900 & 0.49442700 & 2.28987300 \\ \mathrm{H} & -3.49134500 & -1.01313700 & 2.10070800 \\ \mathrm{H} & -1.38186400 & -1.31779400 & 3.48524200 \\ \mathrm{H} & -1.35739200 & -2.29558800 & 2.01013200 \\ \mathrm{H} & 1.09105300 & -1.58098700 & 3.44663100 \\ \mathrm{H} & 0.88874500 & -2.48856000 & 1.93885500 \\ \mathrm{H} & 2.60313600 & 0.02453700 & 2.31439200 \\ \mathrm{H} & 3.20751800 & -1.60514000 & 2.03542600 \\ \mathrm{H} & 2.92999300 & -3.46093700 & 0.73898400 \\ \mathrm{H} & 1.40631000 & -3.47976300 & -0.17543500 \\ \mathrm{H} & 2.87110800 & -4.19900800 & -0.86337000 \\ \mathrm{H} & 2.69834700 & -2.85457500 & -2.94042000 \\ \mathrm{H} & 3.93519700 & -1.93876700 & -0.96356400 \\ \mathrm{H} & 1.20210400 & -2.10449800 & -2.34767600 \\ \mathrm{H} & 2.54650700 & -1.09404800 & -2.90124000 \\ \mathrm{H} & 4.81533200 & 0.22300700 & 1.36804300 \\ \mathrm{H} & 5.29131400 & -0.38884000 & -0.22323900 \\ \mathrm{H} & 4.03718700 & 0.45369900 & -2.32822500 \\ \mathrm{H} & 5.50395400 & 1.31881300 & 0.16547700 \\ \mathrm{H} & 4.10992400 & 2.13884000 & -1.81465000 \\ \mathrm{H} & 2.54476800 & 1.38813200 & -2.16465000 \\ \mathrm{H} & 3.03510600 & 1.62196200 & 0.32113100 \\ \mathrm{H} & -3.26650700 & -2.59225700 & -2.80122800 \\ \mathrm{H} & -1.65883600 & -2.05319200 & -2.27408200 \\ \mathrm{O} & -0.03403700 & 1.88184600 & 0.15595500 \\ \mathrm{C} & 0.07521000 & 2.71807800 & -1.02481900 \\ \mathrm{C} & 0.40215600 & 2.60867900 & 1.32995000 \\ \mathrm{C} & 0.99925600 & 3.85784200 & -0.61780400 \\ \mathrm{H} & 0.45440900 & 2.09671800 & -1.83944600 \\ \mathrm{H} & -0.92418900 & 3.07966500 & -1.28612600 \\ \mathrm{C} & 0.63304700 & 4.04537200 & 0.86217300 \\ \mathrm{H} & -0.37437300 & 2.52363800 & 2.09485600 \\ \mathrm{H} & 1.32493500 & 2.14680200 & 1.69813200 \\ & 0.83503000 & 4.75536100 & -1.21752900 \\ \mathrm{H} & 2.04639900 & 3.55930400 & -0.72301000 \\ \mathrm{H} & 1.41476000 & 4.54201000 & 1.44034000\end{array}$

\footnotetext{
$\left({ }^{(\mathrm{Pr} P N}{ }^{\mathrm{H}} \mathrm{P}\right) \mathrm{Fe}(\mathrm{H})(\mathrm{CO})\left(\mathrm{OCH}_{3}\right)\left(\right.$ 9) $\mathbf{B 3 L} \mathbf{L P} * \quad \mathrm{G}_{\mathrm{THF}}=-1080374.72 \mathrm{kcal} / \mathrm{mol}$

$\mathrm{Fe} \quad-0.06222000 \quad-0.01046000 \quad 0.10229300$

$\mathrm{H} \quad-0.08296700 \quad-1.44897600 \quad 0.61144200$

$\mathrm{P} \quad 2.17637900 \quad-0.07325900 \quad-0.00428700$
} 


\begin{tabular}{|c|c|c|c|}
\hline $\mathrm{P}$ & -2.27823900 & -0.13685800 & -0.15448800 \\
\hline $\mathrm{O}$ & -0.09851800 & 0.68703900 & 2.90939800 \\
\hline $\mathrm{N}$ & 0.01279600 & -0.84664200 & -1.82795900 \\
\hline $\mathrm{H}$ & 0.00714100 & -0.03161800 & -2.44054400 \\
\hline $\mathrm{C}$ & -0.09652100 & 0.45182400 & 1.76452400 \\
\hline $\mathrm{C}$ & 2.46805100 & -0.72861200 & -1.71968400 \\
\hline $\mathrm{H}$ & 2.53490300 & 0.12840300 & -2.39714800 \\
\hline $\mathrm{H}$ & 3.40125900 & -1.29147000 & -1.81155300 \\
\hline $\mathrm{C}$ & 1.26620600 & -1.58926700 & -2.09943000 \\
\hline $\mathrm{H}$ & 1.31547400 & -1.88354400 & -3.15679500 \\
\hline $\mathrm{H}$ & 1.23558500 & -2.49932200 & -1.49670100 \\
\hline $\mathrm{C}$ & -1.17973700 & -1.65946400 & -2.16627300 \\
\hline $\mathrm{H}$ & -1.13014000 & -2.56360200 & -1.55576700 \\
\hline $\mathrm{H}$ & -1.15065600 & -1.96040200 & -3.22249000 \\
\hline $\mathrm{C}$ & -2.45064600 & -0.87238400 & -1.85884100 \\
\hline $\mathrm{H}$ & -3.33627400 & -1.50725800 & -1.95492300 \\
\hline $\mathrm{H}$ & -2.56084200 & -0.04604300 & -2.56902800 \\
\hline $\mathrm{C}$ & 3.14716500 & -1.20104800 & 1.12920100 \\
\hline $\mathrm{H}$ & 2.88101500 & -0.84669800 & 2.13327400 \\
\hline $\mathrm{C}$ & 4.67129400 & -1.13155200 & 0.96842500 \\
\hline $\mathrm{H}$ & 4.97650300 & -1.36259000 & -0.05771700 \\
\hline $\mathrm{H}$ & 5.14614000 & -1.86964100 & 1.62466700 \\
\hline $\mathrm{H}$ & 5.07376200 & -0.15157100 & 1.22878200 \\
\hline $\mathrm{C}$ & 2.66187200 & -2.65182700 & 0.99480300 \\
\hline $\mathrm{H}$ & 1.57468900 & -2.71822600 & 1.07399200 \\
\hline $\mathrm{H}$ & 3.11344700 & -3.26802500 & 1.77971500 \\
\hline $\mathrm{H}$ & 2.96494000 & -3.07814300 & 0.03203100 \\
\hline $\mathrm{C}$ & 2.96451100 & 1.61422800 & 0.04661000 \\
\hline $\mathrm{H}$ & 2.14924500 & 2.19612600 & -0.40084900 \\
\hline $\mathrm{C}$ & 4.24847700 & 1.82207400 & -0.76472200 \\
\hline $\mathrm{H}$ & 5.09877400 & 1.27448300 & -0.35141400 \\
\hline $\mathrm{H}$ & 4.51058600 & 2.88668200 & -0.76187500 \\
\hline $\mathrm{H}$ & 4.13129700 & 1.51918000 & -1.80861500 \\
\hline $\mathrm{C}$ & 3.11510700 & 2.09416100 & 1.49797300 \\
\hline $\mathrm{H}$ & 2.18068600 & 1.99177500 & 2.05582500 \\
\hline $\mathrm{H}$ & 3.39701500 & 3.15276700 & 1.50964400 \\
\hline $\mathrm{H}$ & 3.89273300 & 1.54302500 & 2.03637600 \\
\hline $\mathrm{C}$ & -3.32999300 & -1.27016400 & 0.89747700 \\
\hline $\mathrm{H}$ & -4.34414300 & -1.21634200 & 0.48359900 \\
\hline $\mathrm{C}$ & -2.85003800 & -2.72396700 & 0.80215400 \\
\hline $\mathrm{H}$ & -2.92172600 & -3.11667600 & -0.21593100 \\
\hline $\mathrm{H}$ & -3.47039100 & -3.35936600 & 1.44397700 \\
\hline $\mathrm{H}$ & -1.80975300 & -2.81063300 & 1.12819900 \\
\hline $\mathrm{C}$ & -3.36720700 & -0.80757100 & 2.35947400 \\
\hline $\mathrm{H}$ & -2.36339500 & -0.79159400 & 2.79244100 \\
\hline $\mathrm{H}$ & -3.97882100 & -1.49688600 & 2.95211400 \\
\hline $\mathrm{H}$ & -3.79686600 & 0.19123600 & 2.46661400 \\
\hline $\mathrm{C}$ & -3.23186300 & 1.46401400 & -0.29731100 \\
\hline $\mathrm{H}$ & -2.84736300 & 1.87243500 & -1.23915300 \\
\hline $\mathrm{C}$ & -4.74894700 & 1.28853400 & -0.42532200 \\
\hline $\mathrm{H}$ & -5.21697500 & 2.25049800 & -0.66254900 \\
\hline
\end{tabular}




$\begin{array}{lrrr}\mathrm{H} & -5.19264400 & 0.93233800 & 0.50973900 \\ \mathrm{H} & -5.01876800 & 0.58252100 & -1.21750900 \\ \mathrm{C} & -2.83634400 & 2.45369500 & 0.80655300 \\ \mathrm{H} & -3.11244400 & 2.09547700 & 1.80269700 \\ \mathrm{H} & -3.34980400 & 3.40951500 & 0.64792900 \\ \mathrm{H} & -1.75752800 & 2.61508000 & 0.76200800 \\ \mathrm{O} & -0.04150600 & 1.89848600 & -0.63211800 \\ \mathrm{C} & -0.07173500 & 2.18851300 & -1.97355200 \\ \mathrm{H} & -0.13434000 & 3.27886700 & -2.15628100 \\ \mathrm{H} & 0.83181900 & 1.85735500 & -2.54423900 \\ \mathrm{H} & -0.94284000 & 1.75976500 & -2.52685700\end{array}$

$\begin{array}{cccc}\left(\mathrm{Pr}^{\mathrm{Pr}} \mathrm{H}^{\mathrm{H}} \mathrm{P}\right) \mathrm{Fe}(\mathrm{H})\left(\mathrm{OCH}_{3}\right)(\mathbf{9} \text { no CO singlet }) & \mathbf{B 3 L} \mathbf{L P} * \\ \mathrm{Fe} & -0.05685000 & 0.17523000 & 0.08162300 \\ \mathrm{H} & -0.10296400 & -1.01254400 & 1.09028700 \\ \mathrm{P} & 2.20587900 & 0.01218200 & 0.03700900 \\ \mathrm{P} & -2.29877700 & -0.03714700 & -0.03681300 \\ \mathrm{~N} & -0.00574100 & -0.97915300 & -1.61539000 \\ \mathrm{H} & 0.00092400 & -0.22670400 & -2.30790500 \\ \mathrm{C} & 2.45014300 & -0.89254700 & -1.57143200 \\ \mathrm{H} & 2.51057800 & -0.14128100 & -2.36611300 \\ \mathrm{H} & 3.37217400 & -1.47944600 & -1.60673500 \\ \mathrm{C} & 1.22822500 & -1.77508300 & -1.80330400 \\ \mathrm{H} & 1.24937700 & -2.21800800 & -2.80873300 \\ \mathrm{H} & 1.19273000 & -2.59042400 & -1.07745100 \\ \mathrm{C} & -1.21361200 & -1.80087600 & -1.85376000 \\ \mathrm{H} & -1.18653600 & -2.62305000 & -1.13553600 \\ \mathrm{H} & -1.19038600 & -2.23326700 & -2.86374700 \\ \mathrm{C} & -2.45844000 & -0.94554900 & -1.65609200 \\ \mathrm{H} & -3.36973800 & -1.54404200 & -1.73596700 \\ \mathrm{H} & -2.49859500 & -0.18173100 & -2.44121600 \\ \mathrm{C} & 3.15910500 & -1.00418700 & 1.29488700 \\ \mathrm{H} & 2.95939700 & -0.49110800 & 2.24457800 \\ \mathrm{C} & 4.67720400 & -1.07500400 & 1.08461500 \\ \mathrm{H} & 4.92657800 & -1.47570400 & 0.09632200 \\ \mathrm{H} & 5.12264700 & -1.74503400 & 1.82904200 \\ \mathrm{H} & 5.16118000 & -0.10278300 & 1.18671000 \\ \mathrm{C} & 2.57456200 & -2.42113500 & 1.39274700 \\ \mathrm{H} & 1.48697500 & -2.39355000 & 1.48893900 \\ \mathrm{H} & 2.99822500 & -2.94009300 & 2.25970000 \\ \mathrm{H} & 2.83068300 & -3.01054100 & 0.50512100 \\ \mathrm{C} & 3.13984600 & 1.62243900 & -0.17869400 \\ \mathrm{H} & 2.37394800 & 2.21261600 & -0.69741400 \\ \mathrm{C} & 4.40104000 & 1.61027100 & -1.05226400 \\ \mathrm{H} & 5.21153700 & 1.02991400 & -0.60611800 \\ \mathrm{H} & 4.76414200 & 2.63681500 & -1.18277000 \\ \mathrm{H} & 4.20808300 & 1.20462600 & -2.04868100 \\ \mathrm{C} & 3.40790100 & 2.27645800 & 1.18598300 \\ \mathrm{H} & 2.52117700 & 2.26637500 & 1.82667200 \\ \mathrm{H} & 3.71040000 & 3.32058200 & 1.05003400 \\ \mathrm{H} & 4.21408000 & 1.76941300 & 1.72486400 \\ & & & \\ \mathrm{H} & & & \end{array}$




$\begin{array}{lrrr}\mathrm{C} & -3.24465900 & -1.08178000 & 1.20243800 \\ \mathrm{H} & -4.31306900 & -0.90406500 & 1.02467200 \\ \mathrm{C} & -2.96181100 & -2.57907200 & 1.02535200 \\ \mathrm{H} & -3.29016300 & -2.95688700 & 0.05352900 \\ \mathrm{H} & -3.49075600 & -3.14993500 & 1.79683900 \\ \mathrm{H} & -1.89079300 & -2.77742400 & 1.13364400 \\ \mathrm{C} & -2.89296900 & -0.66209800 & 2.63739800 \\ \mathrm{H} & -1.83025100 & -0.84180800 & 2.82274900 \\ \mathrm{H} & -3.47507400 & -1.25352700 & 3.35360300 \\ \mathrm{H} & -3.09561900 & 0.39254200 & 2.83253300 \\ \mathrm{C} & -3.41587900 & 1.44438800 & -0.33156300 \\ \mathrm{H} & -2.78296400 & 2.07740200 & -0.96657800 \\ \mathrm{C} & -4.72020000 & 1.12648300 & -1.07475200 \\ \mathrm{H} & -5.30288700 & 2.04414300 & -1.21675500 \\ \mathrm{H} & -5.34401400 & 0.43012000 & -0.50358900 \\ \mathrm{H} & -4.54620100 & 0.69108500 & -2.06123900 \\ \mathrm{C} & -3.72598400 & 2.21362400 & 0.96101500 \\ \mathrm{H} & -4.44625800 & 1.66796700 & 1.57878700 \\ \mathrm{H} & -4.17364000 & 3.18377400 & 0.71882700 \\ \mathrm{H} & -2.83366200 & 2.39766300 & 1.56467500 \\ \mathrm{O} & -0.02499700 & 1.91344800 & -0.92424200 \\ \mathrm{C} & -0.10032800 & 2.40764600 & 0.33744700 \\ \mathrm{H} & -1.03006400 & 2.95077200 & 0.57696000 \\ \mathrm{H} & -0.09127200 & 1.57076000 & 1.19074400 \\ \mathrm{H} & 0.75697500 & 3.02751000 & 0.65310400\end{array}$

$\begin{array}{lrrrr}\left.{ }^{\left(\mathrm{Pr} P N^{\mathrm{H}} \mathrm{P}\right) \mathrm{Fe}(\mathrm{H})\left(\mathrm{OCH}_{3}\right)(\mathbf{9}} \text { no CO triplet }\right) & \mathbf{B 3 L Y P} * & \mathrm{G}_{\mathrm{THF}}=-1009244.074 \mathrm{kcal} / \mathrm{mol} \\ \mathrm{Fe} & 0.05717500 & 0.07158100 & -0.30069400 \\ \mathrm{H} & 0.00842700 & -1.28354600 & -1.13071400 \\ \mathrm{P} & -2.20016900 & -0.03492900 & -0.15216200 \\ \mathrm{P} & 2.33801800 & -0.10488100 & -0.02696600 \\ \mathrm{~N} & -0.02940900 & -0.67507600 & 1.85712600 \\ \mathrm{H} & 0.01663700 & 0.18560300 & 2.40069000 \\ \mathrm{C} & -2.47420600 & -0.49634800 & 1.63861600 \\ \mathrm{H} & -2.51781000 & 0.43417500 & 2.21391600 \\ \mathrm{H} & -3.42431500 & -1.01569700 & 1.79684000 \\ \mathrm{C} & -1.30442200 & -1.34893600 & 2.14457800 \\ \mathrm{H} & -1.42333500 & -1.55456600 & 3.21908300 \\ \mathrm{H} & -1.28415900 & -2.31227900 & 1.62847000 \\ \mathrm{C} & 1.16779700 & -1.47883100 & 2.14733400 \\ \mathrm{H} & 1.08396900 & -2.40357100 & 1.56894000 \\ \mathrm{H} & 1.22211000 & -1.75987400 & 3.21013400 \\ \mathrm{C} & 2.43056900 & -0.70858700 & 1.74588800 \\ \mathrm{H} & 3.31984600 & -1.32292700 & 1.91768800 \\ \mathrm{H} & 2.52757200 & 0.18045700 & 2.37965300 \\ \mathrm{C} & -3.19083700 & -1.30920800 & -1.10971600 \\ \mathrm{H} & -2.95417300 & -1.08154600 & -2.15674900 \\ \mathrm{C} & -4.71246500 & -1.25052300 & -0.92442500 \\ \mathrm{H} & -4.99380700 & -1.34737700 & 0.12955500 \\ \mathrm{H} & -5.18312600 & -2.07987200 & -1.46482600 \\ \mathrm{H} & -5.14330100 & -0.32359300 & -1.30570800\end{array}$




$\begin{array}{lrrr}\mathrm{C} & -2.67391300 & -2.72319200 & -0.80736600 \\ \mathrm{H} & -1.58699700 & -2.77723200 & -0.90224400 \\ \mathrm{H} & -3.12383000 & -3.44002300 & -1.50294300 \\ \mathrm{H} & -2.95334300 & -3.03464500 & 0.20505800 \\ \mathrm{C} & -3.05260300 & 1.61429200 & -0.38554000 \\ \mathrm{H} & -2.27180900 & 2.29013800 & -0.02240800 \\ \mathrm{C} & -4.33586400 & 1.88580500 & 0.40803200 \\ \mathrm{H} & -5.17013700 & 1.26236800 & 0.08004800 \\ \mathrm{H} & -4.63398200 & 2.93241200 & 0.27364800 \\ \mathrm{H} & -4.19639600 & 1.72159500 & 1.48001000 \\ \mathrm{C} & -3.22187600 & 1.90046400 & -1.88531700 \\ \mathrm{H} & -2.28417300 & 1.74238100 & -2.42827200 \\ \mathrm{H} & -3.52638600 & 2.94181800 & -2.03641900 \\ \mathrm{H} & -3.98688600 & 1.26448700 & -2.34121900 \\ \mathrm{C} & 3.40681600 & -1.34423100 & -0.93310700 \\ \mathrm{H} & 4.40620500 & -1.30256800 & -0.48336200 \\ \mathrm{C} & 2.85150300 & -2.76339800 & -0.75382200 \\ \mathrm{H} & 2.88170800 & -3.08817500 & 0.28997700 \\ \mathrm{H} & 3.44960300 & -3.47299200 & -1.33643500 \\ \mathrm{H} & 1.81482400 & -2.81888700 & -1.09992800 \\ \mathrm{C} & 3.51274800 & -0.98667800 & -2.42093800 \\ \mathrm{H} & 2.51892300 & -0.91552200 & -2.87620900 \\ \mathrm{H} & 4.07303200 & -1.76168700 & -2.95575400 \\ \mathrm{H} & 4.02709000 & -0.03614300 & -2.58091500 \\ \mathrm{C} & 3.33072200 & 1.47711600 & 0.07047000 \\ \mathrm{H} & 2.86671200 & 1.97512100 & 0.93003600 \\ \mathrm{C} & 4.82137300 & 1.27183900 & 0.35813900 \\ \mathrm{H} & 5.30353100 & 2.23764400 & 0.54735600 \\ \mathrm{H} & 5.33354500 & 0.81381600 & -0.49418600 \\ \mathrm{H} & 4.99110800 & 0.63736900 & 1.23383900 \\ \mathrm{C} & 3.08212500 & 2.37730800 & -1.14664400 \\ \mathrm{H} & 3.46124300 & 1.93494400 & -2.07248700 \\ \mathrm{H} & 3.59558300 & 3.33647500 & -1.00927700 \\ \mathrm{H} & 2.01008400 & 2.56115500 & -1.24082300 \\ \mathrm{O} & 0.19383300 & 1.97306500 & 0.13189900 \\ \mathrm{C} & -0.08206800 & 2.51287400 & 1.37040000 \\ \mathrm{H} & -0.05979800 & 3.61880400 & 1.35060600 \\ \mathrm{H} & -1.07941900 & 2.24296400 & 1.78215500 \\ \mathrm{H} & 0.65396200 & 2.21745500 & 2.15357700\end{array}$

$\left({ }^{\mathrm{PP}}{ }^{\mathrm{PN}}{ }^{\mathrm{H}} \mathrm{P}\right) \mathrm{Fe}(\mathrm{H})\left(\mathrm{OCH}_{3}\right)(9$ no CO quintet $)$ B3LYP* $\quad \mathrm{G}_{\mathrm{THF}}=-1009176.291 \mathrm{kcal} / \mathrm{mol}$ $\begin{array}{llll}\mathrm{Fe} & 0.03705100 & 0.10314800 & -0.63429900\end{array}$

$\mathrm{H} \quad 0.07737300 \quad-1.06796600 \quad-1.89136400$

$\begin{array}{llll}\mathrm{P} & -2.68031800 & -0.04172900 & -0.15489100\end{array}$

$\begin{array}{llll}\mathrm{P} & 2.75591700 & -0.12297400 & 0.01582800\end{array}$

$\mathrm{N} \quad-0.02784500-0.83036100 \quad 1.49465700$

$\mathrm{H} \quad-0.00687300 \quad-0.01186200 \quad 2.10648600$

$\begin{array}{llll}\mathrm{C} & -2.52909700 & -0.69472900 & 1.59417100\end{array}$

$\mathrm{H} \quad-2.46182700 \quad 0.17086600 \quad 2.26471400$

$\mathrm{H} \quad-3.41417000 \quad-1.26009600 \quad 1.90548000$

C $\quad-1.28227500-1.56855300 \quad 1.78166100$ 


\begin{tabular}{|c|c|c|c|}
\hline $\mathrm{H}$ & -1.26423500 & -1.95482800 & 2.81221000 \\
\hline $\mathrm{H}$ & -1.30800300 & -2.43606700 & 1.11507000 \\
\hline $\mathrm{C}$ & 1.16036000 & -1.65934700 & 1.81315100 \\
\hline $\mathrm{H}$ & 1.16194900 & -2.50348100 & 1.11614400 \\
\hline $\mathrm{H}$ & 1.06666900 & -2.07860900 & 2.82669600 \\
\hline $\mathrm{C}$ & 2.46878700 & -0.86651000 & 1.71774600 \\
\hline $\mathrm{H}$ & 3.30093200 & -1.51341500 & 2.01795000 \\
\hline $\mathrm{H}$ & 2.44050000 & -0.04053900 & 2.43958200 \\
\hline $\mathrm{C}$ & -3.86133100 & -1.23011300 & -1.03011100 \\
\hline $\mathrm{H}$ & -3.93403100 & -0.79936800 & -2.03786900 \\
\hline $\mathrm{C}$ & -5.28434800 & -1.37329800 & -0.46646900 \\
\hline $\mathrm{H}$ & -5.28002500 & -1.69106700 & 0.58241600 \\
\hline $\mathrm{H}$ & -5.82919600 & -2.13767300 & -1.03514600 \\
\hline $\mathrm{H}$ & -5.85525700 & -0.44510900 & -0.53805000 \\
\hline $\mathrm{C}$ & -3.19628300 & -2.61360100 & -1.17061200 \\
\hline $\mathrm{H}$ & -2.17819100 & -2.54194500 & -1.56385400 \\
\hline $\mathrm{H}$ & -3.78405000 & -3.23854000 & -1.85340400 \\
\hline $\mathrm{H}$ & -3.15773300 & -3.13652100 & -0.20776300 \\
\hline $\mathrm{C}$ & -3.57855300 & 1.60518500 & 0.05551900 \\
\hline $\mathrm{H}$ & -2.75844500 & 2.24905500 & 0.39852500 \\
\hline $\mathrm{C}$ & -4.70651400 & 1.70467500 & 1.09740300 \\
\hline $\mathrm{H}$ & -5.59931700 & 1.14957300 & 0.79876100 \\
\hline $\mathrm{H}$ & -4.99848600 & 2.75611000 & 1.21449600 \\
\hline $\mathrm{H}$ & -4.39873300 & 1.34152100 & 2.08249100 \\
\hline $\mathrm{C}$ & -4.02954600 & 2.13828100 & -1.31669400 \\
\hline $\mathrm{H}$ & -3.21619200 & 2.11576300 & -2.04960700 \\
\hline $\mathrm{H}$ & -4.36681400 & 3.17716000 & -1.22223000 \\
\hline $\mathrm{H}$ & -4.86663800 & 1.55790000 & -1.72065500 \\
\hline $\mathrm{C}$ & 4.02659400 & -1.30857200 & -0.72566000 \\
\hline $\mathrm{H}$ & 4.89775900 & -1.32083400 & -0.05772700 \\
\hline $\mathrm{C}$ & 3.46420100 & -2.73920400 & -0.80445600 \\
\hline $\mathrm{H}$ & 3.22733700 & -3.15059100 & 0.18134700 \\
\hline $\mathrm{H}$ & 4.20909300 & -3.40145800 & -1.26197000 \\
\hline $\mathrm{H}$ & 2.55864200 & -2.78023400 & -1.41942400 \\
\hline $\mathrm{C}$ & 4.47644400 & -0.83708400 & -2.11917200 \\
\hline $\mathrm{H}$ & 3.62267400 & -0.74572200 & -2.80048400 \\
\hline $\mathrm{H}$ & 5.17297900 & -1.56530800 & -2.55215400 \\
\hline $\mathrm{H}$ & 4.98865500 & 0.12816900 & -2.08852000 \\
\hline $\mathrm{C}$ & 3.71546300 & 1.43899900 & 0.48235800 \\
\hline $\mathrm{H}$ & 3.06550300 & 1.87134300 & 1.25557400 \\
\hline $\mathrm{C}$ & 5.10232900 & 1.20949100 & 1.10354000 \\
\hline $\mathrm{H}$ & 5.50896600 & 2.16028700 & 1.47005800 \\
\hline $\mathrm{H}$ & 5.81252600 & 0.81402800 & 0.36923200 \\
\hline $\mathrm{H}$ & 5.06992700 & 0.51556700 & 1.95014300 \\
\hline $\mathrm{C}$ & 3.76765000 & 2.45340100 & -0.67406500 \\
\hline $\mathrm{H}$ & 4.42618400 & 2.11956200 & -1.48224300 \\
\hline $\mathrm{H}$ & 4.15968700 & 3.41128800 & -0.31040900 \\
\hline $\mathrm{H}$ & 2.77215100 & 2.62628000 & -1.09317900 \\
\hline $\mathrm{O}$ & 0.05697500 & 2.00572600 & -0.70310400 \\
\hline $\mathrm{C}$ & 0.05570700 & 2.93424400 & 0.34095100 \\
\hline $\mathrm{H}$ & -0.45672700 & 3.86632600 & 0.04418200 \\
\hline
\end{tabular}




$\begin{array}{lrrr}\mathrm{H} & -0.45838400 & 2.56715100 & 1.24967500 \\ \mathrm{H} & 1.07811900 & 3.21910200 & 0.64920200\end{array}$

\begin{tabular}{llrr} 
CO BP86* & \multicolumn{3}{c}{$\mathrm{G}_{\mathrm{THF}}=-71109.77608 \mathrm{kcal} / \mathrm{mol}$} \\
$\mathrm{O}$ & 0.00000000 & 0.00000000 & 0.49268700 \\
$\mathrm{C}$ & 0.00000000 & 0.00000000 & -0.65691600
\end{tabular}

$\left[\left({ }^{\mathrm{iPr} P N}{ }^{\mathrm{H} P}\right) \mathrm{Fe}(\mathrm{H})(\mathrm{CO})(\mathrm{THF})\right]^{+}($5-THF $)$BP86* $^{*} \quad \mathrm{G}_{\mathrm{THF}}=-1153971.987 \mathrm{kcal} / \mathrm{mol}$

$\begin{array}{llll}\mathrm{Fe} & 0.02790000 & -0.22942300 & -0.01011900\end{array}$

$\begin{array}{llll}\mathrm{P} & 2.23082200 & -0.34384800 & 0.16587300\end{array}$

$\begin{array}{llll}\mathrm{P} & -2.16100300 & -0.50423400 & 0.12534000\end{array}$

$\begin{array}{llll}\mathrm{O} & 0.05562800 & -0.14609000 & -2.90447900\end{array}$

$\begin{array}{llll}\mathrm{N} & 0.01769100 & -0.47140100 & 2.05870700\end{array}$

$\mathrm{H} \quad-0.03228400 \quad 0.49396900 \quad 2.41461600$

C $\quad 3.10280400 \quad-1.86285400 \quad-0.50810300$

$\begin{array}{llll}\text { C } & -2.55576100 & -3.30505500 & 0.25047900\end{array}$

$\mathrm{H} \quad-1.46137000 \quad-3.43703800 \quad 0.31681000$

$\mathrm{H} \quad-2.97320000 \quad-4.20760700 \quad-0.22799400$

$\mathrm{H} \quad-2.96845600 \quad-3.25138400 \quad 1.27024600$

C $\quad 3.26796000 \quad 1.12821800 \quad-0.36209400$

$\begin{array}{llll}\text { C } & -3.31300900 & 0.89010700 & -0.38443300\end{array}$

$\begin{array}{llll}\mathrm{H} & -2.83250300 & 1.77525500 & 0.07582500\end{array}$

$\begin{array}{llll}\text { C } & -1.18146400 & -1.19113800 & 2.59218300\end{array}$

$\begin{array}{llll}\text { C } & 2.86767100 & -3.09583200 & 0.38081400\end{array}$

$\begin{array}{llll}\text { C } & 0.04198800 & -0.17067000 & -1.72060600\end{array}$

$\begin{array}{llll}\text { C } & -4.73682400 & 0.75374700 & 0.18186200\end{array}$

$\begin{array}{llll}\mathrm{H} & -4.75017600 & 0.68052500 & 1.28064600\end{array}$

$\begin{array}{llll}\text { C } & 4.66762100 & 1.15489800 & 0.27633600\end{array}$

C $\quad 2.64628400 \quad-2.16509400 \quad-1.94617400$

C $\quad-2.89797000 \quad-2.07111300-0.60165300$

$\mathrm{H} \quad-3.99435700 \quad-1.92268800 \quad-0.59320100$

$\begin{array}{lllll}\text { C } & & -3.33891200 & 1.09506700 & -1.90922100\end{array}$

$\begin{array}{llll}\text { C } & 3.36049900 & 1.25714500 & -1.89288100\end{array}$

$\begin{array}{llll}\text { C } & 1.26885300 & -1.06437400 & 2.62649100\end{array}$

$\begin{array}{llll}\text { C } & 2.48467800 & -0.37904800 & 2.01344200\end{array}$

$\begin{array}{llll}\text { C } & -2.41913600 & -2.29181300 & -2.04686200\end{array}$

$\begin{array}{llll}\text { C } & -2.45262900 & -0.62603900 & 1.96607200\end{array}$

$\mathrm{H} \quad 0.07867200 \quad-1.71490800 \quad-0.10028500$

$\mathrm{H} \quad-2.32984500 \quad 1.11033200 \quad-2.35059400$

$\mathrm{H} \quad-3.83265300 \quad 2.05216800 \quad-2.14866700$

$\mathrm{H} \quad-3.91427600 \quad 0.29560600 \quad-2.40489500$

$\mathrm{H} \quad-5.33456000 \quad 1.63725400 \quad-0.10197500$

$\mathrm{H} \quad-5.24795700 \quad-0.13382800 \quad-0.22809900$

$\mathrm{H} \quad-2.60275900 \quad-1.42759100 \quad-2.70146500$

$\mathrm{H} \quad-2.65183800 \quad 0.39239000 \quad 2.34492200$

$\mathrm{H} \quad-3.33067700 \quad-1.24234700 \quad 2.21787900$

$\mathrm{H} \quad-1.20663400 \quad-1.11473100 \quad 3.69492800$

$\mathrm{H} \quad-1.05400200 \quad-2.25125800 \quad 2.32480700$

$\mathrm{H} \quad 1.26335300 \quad-0.96941700 \quad 3.72809500$

$\mathrm{H} \quad 1.25321000 \quad-2.13572500 \quad 2.37515100$ 


$\begin{array}{rrrr}\mathrm{H} & 2.54599700 & 0.66996700 & 2.35405100 \\ \mathrm{H} & 3.42169800 & -0.87766400 & 2.30913600 \\ \mathrm{H} & 3.26528100 & -2.97201700 & 1.40049900 \\ \mathrm{H} & 1.78956700 & -3.32632300 & 0.44518300 \\ \mathrm{H} & 3.36958500 & -3.97106600 & -0.06620000 \\ \mathrm{H} & 3.23257300 & -3.00864500 & -2.34949100 \\ \mathrm{H} & 4.18254300 & -1.62003800 & -0.50538000 \\ \mathrm{H} & 1.58211000 & -2.45287600 & -1.94997900 \\ \mathrm{H} & 2.76785400 & -1.31062800 & -2.62758700 \\ \mathrm{H} & 4.63166800 & 1.15354000 & 1.37690600 \\ \mathrm{H} & 5.27429500 & 0.29233100 & -0.04877100 \\ \mathrm{H} & 4.03523200 & 0.49207700 & -2.31229300 \\ \mathrm{H} & 5.20056600 & 2.06870700 & -0.03925900 \\ \mathrm{H} & 3.77649100 & 2.24354900 & -2.15972900 \\ \mathrm{H} & 2.38271700 & 1.15254200 & -2.38921800 \\ \mathrm{H} & 2.67591000 & 1.97653300 & 0.03227600 \\ \mathrm{H} & -2.94090100 & -3.16334300 & -2.47825300 \\ \mathrm{H} & -1.33710100 & -2.50074000 & -2.05677600 \\ \mathrm{O} & 0.04271500 & 1.90441800 & 0.27247200 \\ \mathrm{C} & 0.01260800 & 2.76949600 & -0.90548400 \\ \mathrm{C} & -0.42748900 & 2.65284000 & 1.43820000 \\ \mathrm{C} & 0.07070000 & 4.18430100 & -0.34200100 \\ \mathrm{H} & 0.87084600 & 2.48854800 & -1.53118800 \\ \mathrm{H} & -0.92214900 & 2.58278000 & -1.46333600 \\ \mathrm{C} & -0.80033800 & 4.04826100 & 0.92136900 \\ \mathrm{H} & -1.28928800 & 2.12412600 & 1.88015700 \\ \mathrm{H} & 0.39979500 & 2.68692000 & 2.16971500 \\ \mathrm{H} & -0.31492700 & 4.93208000 & -1.05147800 \\ \mathrm{H} & 1.10801700 & 4.45142900 & -0.07721500 \\ \mathrm{H} & -1.86974700 & 4.08374200 & 0.65209900 \\ \mathrm{H} & -0.60838800 & 4.82862500 & 1.67296200\end{array}$

$\begin{array}{lrrr}\left.\left[{ }^{\left({ }^{\mathrm{Pr}} \mathrm{PN}\right.}{ }^{\mathrm{H}} \mathrm{P}\right) \mathrm{Fe}(\mathrm{H})(\mathrm{THF})\right]^{+}(\mathbf{5}-\mathrm{THF} \text { no CO } & \text { singlet }) \mathbf{B P 8 6}^{*} \mathrm{G}_{\mathrm{THF}}=-1082811.88 \mathrm{kcal} / \mathrm{mol} \\ \mathrm{Fe} & 0.01065500 & -0.22380900 & -0.04767600 \\ \mathrm{P} & 2.20698500 & -0.41464900 & 0.03137700 \\ \mathrm{P} & -2.18265900 & -0.44458300 & 0.00701000 \\ \mathrm{~N} & 0.00133800 & -0.56327600 & 1.92098000 \\ \mathrm{H} & -0.02185400 & 0.37057600 & 2.36058900 \\ \mathrm{C} & 3.00404900 & -1.89617400 & -0.80612000 \\ \mathrm{C} & -2.64758400 & -3.24014800 & -0.10802700 \\ \mathrm{H} & -1.56158500 & -3.39545800 & 0.01766100 \\ \mathrm{H} & -3.04782600 & -4.09760400 & -0.67668400 \\ \mathrm{H} & -3.12256000 & -3.24995500 & 0.88632500 \\ \mathrm{C} & 3.32083900 & 1.04513600 & -0.38672600 \\ \mathrm{C} & -3.37394600 & 0.96104500 & -0.39852300 \\ \mathrm{H} & -2.89686900 & 1.83277700 & 0.09109800 \\ \mathrm{C} & -1.21057500 & -1.30302200 & 2.41220400 \\ \mathrm{C} & 2.75480700 & -3.19199800 & -0.01763000 \\ \mathrm{C} & -4.78463300 & 0.77837900 & 0.18541100 \\ \mathrm{H} & -4.77552600 & 0.67332300 & 1.28177200 \\ \mathrm{C} & 4.73242900 & 0.95089700 & 0.21506900\end{array}$ 


\begin{tabular}{|c|c|c|c|}
\hline $\mathrm{C}$ & 2.43277600 & -2.02973300 & -2.23064900 \\
\hline $\mathrm{C}$ & -2.91157300 & -1.93692100 & -0.87866900 \\
\hline $\mathrm{H}$ & -4.00373600 & -1.77721500 & -0.95481300 \\
\hline $\mathrm{C}$ & -3.43395000 & 1.22925000 & -1.91247700 \\
\hline $\mathrm{C}$ & 3.38617100 & 1.29502400 & -1.90359300 \\
\hline $\mathrm{C}$ & 1.23134100 & -1.25318000 & 2.43947000 \\
\hline $\mathrm{C}$ & 2.48648400 & -0.60390500 & 1.86669400 \\
\hline $\mathrm{C}$ & -2.29799300 & -2.02622400 & -2.28886000 \\
\hline $\mathrm{C}$ & -2.48123900 & -0.68992400 & 1.83333600 \\
\hline $\mathrm{H}$ & 0.01292200 & -1.71200100 & -0.27868200 \\
\hline $\mathrm{H}$ & -2.43157300 & 1.27221800 & -2.37138900 \\
\hline $\mathrm{H}$ & -3.94190000 & 2.18875300 & -2.11056000 \\
\hline $\mathrm{H}$ & -4.00712000 & 0.44095500 & -2.42907200 \\
\hline $\mathrm{H}$ & -5.41171900 & 1.65328600 & -0.06163200 \\
\hline $\mathrm{H}$ & -5.28113200 & -0.11147200 & -0.23863000 \\
\hline $\mathrm{H}$ & -2.50064000 & -1.13348900 & -2.90014500 \\
\hline $\mathrm{H}$ & -2.66624500 & 0.30648600 & 2.27388900 \\
\hline $\mathrm{H}$ & -3.36009800 & -1.31598100 & 2.05682900 \\
\hline $\mathrm{H}$ & -1.22030900 & -1.29952600 & 3.51811500 \\
\hline $\mathrm{H}$ & -1.09437400 & -2.34278400 & 2.07023000 \\
\hline $\mathrm{H}$ & 1.22547000 & -1.23254400 & 3.54517400 \\
\hline $\mathrm{H}$ & 1.15595000 & -2.30180600 & 2.11312000 \\
\hline $\mathrm{H}$ & 2.62150000 & 0.41057000 & 2.28300300 \\
\hline $\mathrm{H}$ & 3.38594900 & -1.18827200 & 2.11946700 \\
\hline $\mathrm{H}$ & 3.20384200 & -3.17036900 & 0.98850200 \\
\hline $\mathrm{H}$ & 1.67042300 & -3.37474200 & 0.08347800 \\
\hline $\mathrm{H}$ & 3.19226300 & -4.04879300 & -0.55916500 \\
\hline $\mathrm{H}$ & 2.87633200 & -2.90409300 & -2.73860800 \\
\hline $\mathrm{H}$ & 4.09291400 & -1.70541900 & -0.85494600 \\
\hline $\mathrm{H}$ & 1.33954500 & -2.17648400 & -2.17635900 \\
\hline $\mathrm{H}$ & 2.62684200 & -1.14305400 & -2.85330300 \\
\hline $\mathrm{H}$ & 4.71723900 & 0.85790800 & 1.31250600 \\
\hline $\mathrm{H}$ & 5.28454300 & 0.08645200 & -0.19298300 \\
\hline $\mathrm{H}$ & 4.02184400 & 0.54252300 & -2.40045900 \\
\hline $\mathrm{H}$ & 5.31112800 & 1.85773700 & -0.03542100 \\
\hline $\mathrm{H}$ & 3.82670700 & 2.28572900 & -2.10878800 \\
\hline $\mathrm{H}$ & 2.39162200 & 1.25952100 & -2.37962800 \\
\hline $\mathrm{H}$ & 2.77843100 & 1.88822100 & 0.08377500 \\
\hline $\mathrm{H}$ & -2.70132400 & -2.90306900 & -2.82531100 \\
\hline $\mathrm{H}$ & -1.20283400 & -2.14200000 & -2.20592600 \\
\hline $\mathrm{O}$ & 0.10891400 & 1.88405200 & 0.12022000 \\
\hline $\mathrm{C}$ & -0.03003600 & 2.72666700 & -1.05718700 \\
\hline $\mathrm{C}$ & -0.23556700 & 2.65784400 & 1.30794100 \\
\hline $\mathrm{C}$ & 0.30301700 & 4.12203900 & -0.54134200 \\
\hline $\mathrm{H}$ & 0.66230700 & 2.32995300 & -1.81450200 \\
\hline $\mathrm{H}$ & -1.06589800 & 2.66670100 & -1.43962700 \\
\hline $\mathrm{C}$ & -0.40025800 & 4.11417100 & 0.83286800 \\
\hline $\mathrm{H}$ & -1.16338800 & 2.24925900 & 1.74858500 \\
\hline $\mathrm{H}$ & 0.59511800 & 2.53523900 & 2.02462900 \\
\hline $\mathrm{H}$ & -0.06656600 & 4.91788200 & -1.20571300 \\
\hline $\mathrm{H}$ & 1.39466300 & 4.23400500 & -0.42777900 \\
\hline
\end{tabular}




\begin{tabular}{|c|c|c|c|c|}
\hline $\mathrm{H}$ & -1.46882800 & 4.35794700 & 0.71294300 & \\
\hline $\mathrm{H}$ & 0.03639700 & 4.83080700 & 1.54443700 & \\
\hline \multicolumn{5}{|c|}{$\left.\left[{ }^{\left({ }^{\mathrm{Pr}} \mathrm{PN}\right.}{ }^{\mathrm{H}} \mathrm{P}\right) \mathrm{Fe}(\mathrm{H})(\mathrm{THF})\right]^{+}($5-THF no CO triplet $) \mathbf{B P 8 6}^{*} \mathrm{G}_{\mathrm{THF}}=-1082816.78 \mathrm{kcal} / \mathrm{mo}$} \\
\hline $\mathrm{Fe}$ & 0.03575500 & -0.15570000 & -0.07395300 & \\
\hline $\mathrm{P}$ & 2.26312100 & -0.31327600 & 0.02151700 & \\
\hline $\mathrm{P}$ & -2.15265800 & -0.53059000 & -0.01507100 & \\
\hline $\mathrm{N}$ & 0.03198400 & -0.68977000 & 2.06441900 & \\
\hline $\mathrm{H}$ & -0.03389600 & 0.18804900 & 2.59794900 & \\
\hline $\mathrm{C}$ & 3.11289800 & -1.74398200 & -0.85003500 & \\
\hline $\mathrm{C}$ & -2.41917400 & -3.33719500 & -0.31442200 & \\
\hline $\mathrm{H}$ & -1.32027400 & -3.41869100 & -0.23582900 & \\
\hline $\mathrm{H}$ & -2.77484900 & -4.18002600 & -0.93218300 & \\
\hline $\mathrm{H}$ & -2.85346300 & -3.45549200 & 0.69129200 & \\
\hline $\mathrm{C}$ & 3.35776900 & 1.18451800 & -0.29579600 & \\
\hline $\mathrm{C}$ & -3.43340400 & 0.82627700 & -0.29964400 & \\
\hline $\mathrm{H}$ & -3.02774800 & 1.67077600 & 0.28995000 & \\
\hline $\mathrm{C}$ & -1.15257300 & -1.52933300 & 2.39353600 & \\
\hline $\mathrm{C}$ & 2.86362500 & -3.07626400 & -0.12486400 & \\
\hline $\mathrm{C}$ & -4.83660000 & 0.49274500 & 0.23375600 & \\
\hline $\mathrm{H}$ & -4.83313400 & 0.25931600 & 1.31008400 & \\
\hline $\mathrm{C}$ & 4.73497400 & 1.10826800 & 0.38432100 & \\
\hline $\mathrm{C}$ & 2.60348300 & -1.83425800 & -2.30060300 & \\
\hline $\mathrm{C}$ & -2.81157400 & -2.00737300 & -0.97757700 & \\
\hline $\mathrm{H}$ & -3.91434000 & -1.92266900 & -0.98731900 & \\
\hline $\mathrm{C}$ & -3.48763400 & 1.25632200 & -1.77525900 & \\
\hline $\mathrm{C}$ & 3.50765800 & 1.46522900 & -1.80160000 & \\
\hline $\mathrm{C}$ & 1.31123300 & -1.35409100 & 2.43696900 & \\
\hline $\mathrm{C}$ & 2.50425900 & -0.58625200 & 1.85960500 & \\
\hline $\mathrm{C}$ & -2.27607700 & -1.95925800 & -2.42015900 & \\
\hline $\mathrm{C}$ & -2.42833700 & -0.92641500 & 1.79795300 & \\
\hline $\mathrm{H}$ & 0.05873200 & -1.64027600 & -0.46085300 & \\
\hline $\mathrm{H}$ & -2.48207100 & 1.40298200 & -2.20431600 & \\
\hline $\mathrm{H}$ & -4.04449800 & 2.20362100 & -1.87553400 & \\
\hline $\mathrm{H}$ & -4.00857300 & 0.50144700 & -2.38772100 & \\
\hline $\mathrm{H}$ & -5.51009300 & 1.35431000 & 0.08048100 & \\
\hline $\mathrm{H}$ & -5.27636500 & -0.36614100 & -0.30137800 & \\
\hline $\mathrm{H}$ & -2.55881800 & -1.03721300 & -2.95061900 & \\
\hline $\mathrm{H}$ & -2.66914500 & 0.02769800 & 2.30209900 & \\
\hline $\mathrm{H}$ & -3.28746300 & -1.59876700 & 1.95921800 & \\
\hline $\mathrm{H}$ & -1.25448200 & -1.66083400 & 3.48801800 & \\
\hline $\mathrm{H}$ & -0.96360300 & -2.52105300 & 1.95249800 & \\
\hline $\mathrm{H}$ & 1.40286400 & -1.44904700 & 3.53611100 & \\
\hline $\mathrm{H}$ & 1.27152400 & -2.37148700 & 2.01674300 & \\
\hline $\mathrm{H}$ & 2.55587200 & 0.41979400 & 2.31494300 & \\
\hline $\mathrm{H}$ & 3.45107700 & -1.10055400 & 2.09457700 & \\
\hline $\mathrm{H}$ & 3.28444400 & -3.09199000 & 0.89319400 & \\
\hline $\mathrm{H}$ & 1.78040300 & -3.28432100 & -0.06335600 & \\
\hline $\mathrm{H}$ & 3.33025700 & -3.90067300 & -0.69142500 & \\
\hline $\mathrm{H}$ & 3.10540700 & -2.66564200 & -2.82590100 & \\
\hline $\mathrm{H}$ & 4.19848300 & -1.52922800 & -0.84793100 & \\
\hline
\end{tabular}




$\begin{array}{lrrr}\mathrm{H} & 1.51651400 & -2.02925400 & -2.30150300 \\ \mathrm{H} & 2.78263700 & -0.91318000 & -2.87549200 \\ \mathrm{H} & 4.66037100 & 1.01063800 & 1.47848900 \\ \mathrm{H} & 5.32317600 & 0.25530400 & 0.00366100 \\ \mathrm{H} & 4.18801800 & 0.73543000 & -2.27227800 \\ \mathrm{H} & 5.31004300 & 2.02615400 & 0.16916800 \\ \mathrm{H} & 3.94031500 & 2.46800400 & -1.95908700 \\ \mathrm{H} & 2.54505900 & 1.41916300 & -2.33841100 \\ \mathrm{H} & 2.77076800 & 2.00431100 & 0.16196700 \\ \mathrm{H} & -2.66596900 & -2.81623900 & -2.99692700 \\ \mathrm{H} & -1.17350900 & -2.02044100 & -2.41093700 \\ \mathrm{O} & 0.08744100 & 1.92704200 & 0.16630000 \\ \mathrm{C} & 0.06447200 & 2.79831900 & -1.00861800 \\ \mathrm{C} & -0.54370800 & 2.60549000 & 1.30172700 \\ \mathrm{C} & -0.09002300 & 4.20257700 & -0.43288000 \\ \mathrm{H} & 1.00186100 & 2.62433800 & -1.55513400 \\ \mathrm{H} & -0.79166300 & 2.51567600 & -1.64718700 \\ \mathrm{C} & -1.03535900 & 3.95136900 & 0.75861500 \\ \mathrm{H} & -1.35735000 & 1.96476200 & 1.68024800 \\ \mathrm{H} & 0.22813500 & 2.71675500 & 2.08265600 \\ \mathrm{H} & -0.50396100 & 4.90942200 & -1.16782400 \\ \mathrm{H} & 0.88528600 & 4.58453800 & -0.08643200 \\ \mathrm{H} & -2.07722200 & 3.86580400 & 0.40508600 \\ \mathrm{H} & -0.99416100 & 4.74300300 & 1.52177500\end{array}$

$\begin{array}{crrr}\left.\left[{ }^{\text {iPrPN }}{ }^{H} \mathrm{P}\right) \mathrm{Fe}(\mathrm{H})(\mathrm{THF})\right]^{+}(\mathbf{5}-\mathbf{T H F} \text { no CO } \\ \mathrm{Fe} & -0.00164900 & -0.26700100 & -0.15894100 \\ \mathrm{P} & 2.53380900 & -0.46868200 & 0.15330700 \\ \mathrm{P} & -2.53976600 & -0.46741200 & 0.14194600 \\ \mathrm{~N} & -0.00839300 & -1.97935500 & 1.26246600 \\ \mathrm{H} & -0.01641300 & -1.57914400 & 2.21309500 \\ \mathrm{C} & 3.56882900 & -1.00682800 & -1.34255200 \\ \mathrm{C} & -3.21503300 & -2.40477600 & -1.85596600 \\ \mathrm{H} & -2.14737900 & -2.47251000 & -2.12967000 \\ \mathrm{H} & -3.81150700 & -2.63892400 & -2.75631200 \\ \mathrm{H} & -3.43615300 & -3.18216200 & -1.10599300 \\ \mathrm{C} & 3.66244900 & 0.69367300 & 1.14911000 \\ \mathrm{C} & -3.66861600 & 0.68626900 & 1.14741900 \\ \mathrm{H} & -3.05449000 & 0.86804800 & 2.05234500 \\ \mathrm{C} & -1.23564900 & -2.80755700 & 1.09700300 \\ \mathrm{C} & 3.22343500 & -2.43273000 & -1.81542800 \\ \mathrm{C} & -5.00894700 & 0.06627900 & 1.59013100 \\ \mathrm{H} & -4.87917500 & -0.86834300 & 2.16005000 \\ \mathrm{C} & 4.98671900 & 0.06625700 & 1.62843900 \\ \mathrm{C} & 3.38152500 & -0.00359700 & -2.50082500 \\ \mathrm{C} & -3.56732300 & -0.98658900 & -1.36532500 \\ \mathrm{H} & -4.62666000 & -0.97777200 & -1.04484700 \\ \mathrm{C} & -3.89294800 & 2.04027500 & 0.44578800 \\ \mathrm{C} & 3.91925700 & 2.02500700 & 0.41578900 \\ \mathrm{C} & 1.22421000 & -2.80298700 & 1.11634300 \\ \mathrm{C} & 2.49145100 & -1.95711700 & 1.30039200\end{array}$ 


$\begin{array}{lrrr}\mathrm{C} & -3.37688000 & 0.03385300 & -2.50786800 \\ \mathrm{C} & -2.50851100 & -1.96850500 & 1.27301000 \\ \mathrm{H} & 0.00064100 & -1.29324600 & -1.46407500 \\ \mathrm{H} & -2.95122600 & 2.47745700 & 0.07468100 \\ \mathrm{H} & -4.34781800 & 2.75788700 & 1.15170400 \\ \mathrm{H} & -4.58436300 & 1.94093400 & -0.40861300 \\ \mathrm{H} & -5.54781600 & 0.77893100 & 2.24114600 \\ \mathrm{H} & -5.66404600 & -0.14550900 & 0.72705200 \\ \mathrm{H} & -3.63192500 & 1.06349300 & -2.20987300 \\ \mathrm{H} & -2.55315000 & -1.58097400 & 2.30857700 \\ \mathrm{H} & -3.39756700 & -2.60769700 & 1.13548900 \\ \mathrm{H} & -1.23443400 & -3.64384100 & 1.82510400 \\ \mathrm{H} & -1.18925900 & -3.24531000 & 0.08558200 \\ \mathrm{H} & 1.21874400 & -3.63413600 & 1.85027200 \\ \mathrm{H} & 1.19085300 & -3.24842800 & 0.10782800 \\ \mathrm{H} & 2.51991000 & -1.55728600 & 2.33186800 \\ \mathrm{H} & 3.38470500 & -2.59452100 & 1.18315300 \\ \mathrm{H} & 3.44145200 & -3.19907500 & -1.05330700 \\ \mathrm{H} & 2.15788100 & -2.50688800 & -2.09567200 \\ \mathrm{H} & 3.82637500 & -2.67785200 & -2.70851100 \\ \mathrm{H} & 4.03521700 & -0.28372100 & -3.34669200 \\ \mathrm{H} & 4.62664500 & -0.99030200 & -1.01710300 \\ \mathrm{H} & 2.33794800 & -0.01720100 & -2.86183500 \\ \mathrm{H} & 3.62962900 & 1.03144300 & -2.21625600 \\ \mathrm{H} & 4.83428400 & -0.84743200 & 2.22586000 \\ \mathrm{H} & 5.64896800 & -0.18345800 & 0.78103000 \\ \mathrm{H} & 4.62451300 & 1.89205900 & -0.42256100 \\ \mathrm{H} & 5.52914700 & 0.79036800 & 2.26364600 \\ \mathrm{H} & 4.37217400 & 2.75465900 & 1.11048900 \\ \mathrm{H} & 2.99153100 & 2.46620600 & 0.01488100 \\ \mathrm{H} & 3.03720100 & 0.90769500 & 2.03925900 \\ \mathrm{H} & -4.02364300 & -0.23687600 & -3.36206600 \\ \mathrm{H} & -2.33079800 & 0.03082300 & -2.86174300 \\ \mathrm{O} & -0.00793200 & 1.88515200 & -0.10905200 \\ \mathrm{C} & -0.03430900 & 2.72152400 & -1.31957200 \\ \mathrm{C} & 0.01847600 & 2.73021700 & 1.09464100 \\ \mathrm{H} & 0.32390400 & 4.12910100 & -0.83562100 \\ \mathrm{H} & 0.68336000 & 2.28897300 & -2.03450000 \\ \mathrm{H} & -1.05262200 & 2.67148800 & -1.74525400 \\ -0.26087500 & 4.15127500 & 0.59335300 \\ \mathrm{H} & -0.73889700 & 2.34145900 & 1.79419300 \\ \mathrm{H} & 1.01973300 & 2.63745400 & 1.55171100 \\ \mathrm{H} & -1.318918600 & 4.90796700 & -1.48584800 \\ \mathrm{H} & 4.26551200 & -0.81059000 \\ \mathrm{H} & & 4.34747000 & 0.56418300 \\ \mathrm{H} & 4.91171100 & 1.23738100\end{array}$

\footnotetext{
$\left({ }^{\mathrm{iPr} P N}{ }^{\mathrm{H}} \mathrm{P}\right) \mathrm{Fe}(\mathrm{H})(\mathrm{CO})\left(\mathrm{OCH}_{3}\right)(\mathbf{9}) \mathbf{B P 8 6}^{*} \mathrm{G}_{\mathrm{THF}}=-1080459.9 \mathrm{kcal} / \mathrm{mol}$ $\begin{array}{llll}\mathrm{Fe} & -0.06122200 & -0.01447300 & 0.07318200\end{array}$

$\mathrm{H} \quad-0.07736400 \quad-1.47459900 \quad 0.47155100$

$\mathrm{P} \quad 2.13676400 \quad-0.07029000 \quad-0.01659300$
} 


\begin{tabular}{|c|c|c|c|}
\hline $\mathrm{P}$ & -2.24053900 & -0.12684100 & -0.15999500 \\
\hline $\mathrm{O}$ & -0.06010100 & 0.50204200 & 2.91720600 \\
\hline $\mathrm{N}$ & 0.01109300 & -0.76545000 & -1.87193700 \\
\hline $\mathrm{H}$ & 0.00699500 & 0.08371400 & -2.45760200 \\
\hline $\mathrm{C}$ & -0.07827800 & 0.33824400 & 1.73738900 \\
\hline $\mathrm{C}$ & 2.47380600 & -0.66731600 & -1.75465200 \\
\hline $\mathrm{H}$ & 2.56314800 & 0.22057000 & -2.40471400 \\
\hline $\mathrm{H}$ & 3.41260000 & -1.23930700 & -1.84242100 \\
\hline $\mathrm{C}$ & 1.26845900 & -1.50569900 & -2.17976500 \\
\hline $\mathrm{H}$ & 1.31247200 & -1.75254800 & -3.25872400 \\
\hline $\mathrm{H}$ & 1.22837700 & -2.44882800 & -1.61167200 \\
\hline $\mathrm{C}$ & -1.18687700 & -1.56990800 & -2.24960600 \\
\hline $\mathrm{H}$ & -1.12702600 & -2.50925300 & -1.67666400 \\
\hline $\mathrm{H}$ & -1.15456000 & -1.81980600 & -3.32826800 \\
\hline $\mathrm{C}$ & -2.45993900 & -0.80225700 & -1.89469600 \\
\hline $\mathrm{H}$ & -3.35141100 & -1.44477800 & -1.98996100 \\
\hline $\mathrm{H}$ & -2.59282500 & 0.05697600 & -2.57611700 \\
\hline $\mathrm{C}$ & 3.08727900 & -1.23835900 & 1.10518900 \\
\hline $\mathrm{H}$ & 2.80692900 & -0.89789000 & 2.12042600 \\
\hline $\mathrm{C}$ & 4.61619100 & -1.16897800 & 0.95522100 \\
\hline $\mathrm{H}$ & 4.92999600 & -1.38917800 & -0.08025800 \\
\hline $\mathrm{H}$ & 5.09217500 & -1.92106200 & 1.60945000 \\
\hline $\mathrm{H}$ & 5.02088300 & -0.18371400 & 1.23091900 \\
\hline $\mathrm{C}$ & 2.58556100 & -2.68196300 & 0.92653500 \\
\hline $\mathrm{H}$ & 1.48583400 & -2.73121100 & 0.98262600 \\
\hline $\mathrm{H}$ & 3.01501400 & -3.33119800 & 1.70935800 \\
\hline $\mathrm{H}$ & 2.90174800 & -3.09127300 & -0.04956700 \\
\hline $\mathrm{C}$ & 2.92126300 & 1.62319300 & 0.11842700 \\
\hline $\mathrm{H}$ & 2.08281500 & 2.21574400 & -0.30386000 \\
\hline $\mathrm{C}$ & 4.20598600 & 1.87400400 & -0.68553500 \\
\hline $\mathrm{H}$ & 5.06504000 & 1.30382000 & -0.29628700 \\
\hline $\mathrm{H}$ & 4.46933700 & 2.94607900 & -0.63164000 \\
\hline $\mathrm{H}$ & 4.08954800 & 1.62023100 & -1.75168500 \\
\hline $\mathrm{C}$ & 3.06595100 & 2.03095000 & 1.59597000 \\
\hline $\mathrm{H}$ & 2.12718400 & 1.87981700 & 2.15259400 \\
\hline $\mathrm{H}$ & 3.33060800 & 3.10101600 & 1.66350700 \\
\hline $\mathrm{H}$ & 3.86168100 & 1.46290800 & 2.10860400 \\
\hline $\mathrm{C}$ & -3.28095000 & -1.30146500 & 0.87303100 \\
\hline $\mathrm{H}$ & -4.30444400 & -1.24134700 & 0.45613100 \\
\hline $\mathrm{C}$ & -2.77942100 & -2.74749100 & 0.73042600 \\
\hline $\mathrm{H}$ & -2.85516000 & -3.11524600 & -0.30625300 \\
\hline $\mathrm{H}$ & -3.38475400 & -3.41817900 & 1.36567800 \\
\hline $\mathrm{H}$ & -1.72444000 & -2.82443100 & 1.04418000 \\
\hline $\mathrm{C}$ & -3.31398400 & -0.87446200 & 2.34950700 \\
\hline $\mathrm{H}$ & -2.29862200 & -0.84997700 & 2.77667400 \\
\hline $\mathrm{H}$ & -3.91399400 & -1.59304100 & 2.93563000 \\
\hline $\mathrm{H}$ & -3.76209900 & 0.12284000 & 2.48479600 \\
\hline $\mathrm{C}$ & -3.20206900 & 1.48520800 & -0.22284300 \\
\hline $\mathrm{H}$ & -2.83121300 & 1.92686100 & -1.16729900 \\
\hline $\mathrm{C}$ & -4.72496500 & 1.30917800 & -0.32395600 \\
\hline $\mathrm{H}$ & -5.20612000 & 2.28589400 & -0.51023600 \\
\hline
\end{tabular}




$\begin{array}{lrrr}\mathrm{H} & -5.14893000 & 0.90912700 & 0.61298700 \\ \mathrm{H} & -5.01481500 & 0.63109700 & -1.14509400 \\ \mathrm{C} & -2.77053000 & 2.43048400 & 0.91115200 \\ \mathrm{H} & -3.03135800 & 2.03430200 & 1.90669300 \\ \mathrm{H} & -3.27721800 & 3.40634300 & 0.79916000 \\ \mathrm{H} & -1.68034700 & 2.57531800 & 0.84308100 \\ \mathrm{O} & -0.03759600 & 1.93962100 & -0.58125400 \\ \mathrm{C} & -0.08164700 & 2.23421700 & -1.92853800 \\ \mathrm{H} & -0.13021300 & 3.33513200 & -2.10254100 \\ \mathrm{H} & 0.81800700 & 1.89263300 & -2.52248600 \\ \mathrm{H} & -0.97617900 & 1.81908400 & -2.47820000\end{array}$

$\left({ }^{\mathrm{iPr} P N}{ }^{\mathrm{H}} \mathrm{P}\right) \mathrm{Fe}(\mathrm{H})\left(\mathrm{OCH}_{3}\right)(9$ no CO singlet $) \mathbf{B P 8 6}^{*} \mathrm{G}_{\mathrm{THF}}=-1009310.485 \mathrm{kcal} / \mathrm{mol}$ $\begin{array}{llll}\mathrm{Fe} & -0.06201500 & 0.25517200 & 0.02637600\end{array}$

$\begin{array}{llll}\mathrm{H} & -0.11243300 & -1.07573500 & 0.72516900\end{array}$

$\begin{array}{llll}\mathrm{P} & 2.12774100 & 0.03553400 & 0.03244100\end{array}$

$\mathrm{P} \quad-2.23066000 \quad 0.00303400 \quad-0.03134200$

$\mathrm{N} \quad-0.01764000 \quad-0.82183600 \quad-1.74050900$

$\mathrm{H} \quad 0.01177700 \quad-0.02013800 \quad-2.38843500$

C $\quad 2.44955400 \quad-0.81064400 \quad-1.60937600$

$\mathrm{H} \quad 2.58175300 \quad-0.01652000 \quad-2.36531100$

$\mathrm{H} \quad 3.36077400 \quad-1.43204100 \quad-1.62048500$

C $\quad 1.21051300 \quad-1.63837400 \quad-1.94749200$

$\mathrm{H} \quad 1.25210400 \quad-2.01561000 \quad-2.98872600$

$\mathrm{H} \quad \begin{array}{llll}\mathrm{H} & 1.12620900 & -2.50741000 & -1.27464800\end{array}$

C $\quad-1.24253500 \quad-1.61706200 \quad-2.03223800$

$\mathrm{H} \quad-1.19519700 \quad-2.51422600 \quad-1.39433800$

$\mathrm{H} \quad-1.24197400 \quad-1.95095800 \quad-3.08878600$

C $\quad \begin{array}{llll}-2.48781100 & -0.79441100 & -1.71093900\end{array}$

$\mathrm{H} \quad \begin{array}{llll}\mathrm{H} & -3.40239800 & -1.40633800 & -1.78436100\end{array}$

$\begin{array}{llll}\mathrm{H} & -2.58346600 & 0.03500500 & -2.43546600\end{array}$

$\begin{array}{llll}\mathrm{C} & 2.98145600 & -1.06248000 & 1.30700600\end{array}$

$\begin{array}{llll}\mathrm{H} & 2.75950100 & -0.55587400 & 2.26602300\end{array}$

C $\quad 4.50625100 \quad-1.19300300 \quad 1.15351000$

$\mathrm{H} \quad 4.77938000 \quad-1.58428600 \quad 0.15779400$

$\mathrm{H} \quad 4.89952100-1.90327600 \quad 1.90302400$

$\begin{array}{llll}\mathrm{H} & 5.02937100 & -0.23609800 & 1.29787900\end{array}$

$\begin{array}{llll}\text { C } & 2.32984800 & -2.45653800 & 1.34096300\end{array}$

$\begin{array}{llll}\mathrm{H} & 1.23196400 & -2.38381400 & 1.40225000\end{array}$

$\mathrm{H} \quad 2.70224200 \quad-3.02810800 \quad 2.20933900$

$\begin{array}{llll}\mathrm{H} & 2.58728300 & -3.03285100 & 0.43426100\end{array}$

C $\quad 3.14793400 \quad 1.61835900 \quad-0.06921400$

$\begin{array}{llll}\mathrm{H} & 2.43090400 & 2.26895500 & -0.60771300\end{array}$

$\begin{array}{lllll}\mathrm{C} & 4.45177500 & 1.58248500 & -0.88536100\end{array}$

$\begin{array}{lllll}\mathrm{H} & 5.21980200 & 0.94391000 & -0.42174600\end{array}$

$\mathrm{H} \quad 4.86947500 \quad 2.60354300 \quad-0.95741700$

$\mathrm{H} \quad 4.29092800 \quad 1.22225000 \quad-1.91399300$

$\begin{array}{llll}\text { C } & 3.37404700 & 2.20418200 & 1.33702000\end{array}$

$\begin{array}{llll}\mathrm{H} & 2.44575400 & 2.21311800 & 1.93262000\end{array}$

$\begin{array}{llll}\mathrm{H} & 3.74033200 & 3.24335700 & 1.26350600\end{array}$

$\begin{array}{llll}\mathrm{H} & 4.12871900 & 1.62803500 & 1.89944300\end{array}$ 


$\begin{array}{lrrr}\mathrm{C} & -3.07147900 & -1.15899000 & 1.19395700 \\ \mathrm{H} & -4.16150600 & -0.98842700 & 1.09892600 \\ \mathrm{C} & -2.77448100 & -2.63425200 & 0.87881200 \\ \mathrm{H} & -3.16407500 & -2.94587000 & -0.10388600 \\ \mathrm{H} & -3.23944100 & -3.28315400 & 1.64230900 \\ \mathrm{H} & -1.68559700 & -2.81774000 & 0.89821700 \\ \mathrm{C} & -2.62530700 & -0.83664600 & 2.63109200 \\ \mathrm{H} & -1.53619600 & -0.98260800 & 2.72119000 \\ \mathrm{H} & -3.13425400 & -1.50855400 & 3.34558600 \\ \mathrm{H} & -2.84683000 & 0.20111800 & 2.92267100 \\ \mathrm{C} & -3.42770600 & 1.46286700 & -0.14514400 \\ \mathrm{H} & -2.87444200 & 2.16229900 & -0.80229900 \\ \mathrm{C} & -4.78063400 & 1.13006700 & -0.79714400 \\ \mathrm{H} & -5.41039100 & 2.03696200 & -0.84670700 \\ \mathrm{H} & -5.33603200 & 0.37904700 & -0.20776200 \\ \mathrm{H} & -4.67312700 & 0.74400800 & -1.82280200 \\ \mathrm{C} & -3.64490000 & 2.14209500 & 1.21868800 \\ \mathrm{H} & -4.28540300 & 1.52227900 & 1.86951400 \\ \mathrm{H} & -4.15630100 & 3.11151300 & 1.08306400 \\ \mathrm{H} & -2.69717600 & 2.32811400 & 1.75016900 \\ \mathrm{O} & 0.01525600 & 1.89406100 & -1.12947900 \\ \mathrm{C} & -0.09648700 & 2.24047600 & 0.14860200 \\ \mathrm{H} & -1.05754500 & 2.67173000 & 0.49163100 \\ \mathrm{H} & -0.07762000 & 0.49312100 & 1.50482300 \\ \mathrm{H} & 0.78097200 & 2.69985000 & 0.64615000\end{array}$

$\begin{array}{cccc}\left({ }^{\mathrm{iPr} P N}{ }^{\mathrm{H}} \mathrm{P}\right) \mathrm{Fe}(\mathrm{H})\left(\mathrm{OCH}_{3}\right)(\mathbf{9} \text { no CO triplet }) & \mathbf{B P 8 6} * \mathrm{G}_{\mathrm{THF}}=-1009310.143 \mathrm{kcal} / \mathrm{mol} \\ \mathrm{Fe} & 0.08233600 & 0.24666700 & -0.15328500 \\ \mathrm{H} & 0.07873700 & -0.01031600 & -1.69772500 \\ \mathrm{P} & -2.11274800 & 0.04988100 & -0.12214000 \\ \mathrm{P} & 2.25457000 & -0.09356300 & 0.02217400 \\ \mathrm{~N} & -0.00497800 & -0.40080900 & 1.86183700 \\ \mathrm{H} & 0.13156900 & 0.59595800 & 2.12096700 \\ \mathrm{C} & -2.47460300 & -0.14456100 & 1.71172500 \\ \mathrm{H} & -2.54731900 & 0.88158700 & 2.11639000 \\ \mathrm{H} & -3.43217100 & -0.64953900 & 1.92448900 \\ \mathrm{C} & -1.30963100 & -0.88733800 & 2.37962500 \\ \mathrm{H} & -1.35713900 & -0.78055500 & 3.48178300 \\ \mathrm{H} & -1.36331600 & -1.96504400 & 2.15480000 \\ \mathrm{C} & 1.14995400 & -1.20227400 & 2.34028300 \\ \mathrm{H} & 1.01382600 & -2.22519500 & 1.94818300 \\ \mathrm{H} & 1.15368500 & -1.26788800 & 3.44734200 \\ \mathrm{C} & 2.46197500 & -0.59460900 & 1.82920700 \\ \mathrm{H} & 3.30226200 & -1.29236200 & 1.98501200 \\ \mathrm{H} & 2.68998800 & 0.32963200 & 2.38961000 \\ \mathrm{C} & -2.68470900 & -1.55763600 & -0.92758700 \\ \mathrm{H} & -2.54915500 & -1.33997100 & -2.00398600 \\ \mathrm{C} & -4.14049100 & -1.98035600 & -0.68175500 \\ \mathrm{H} & -4.35995500 & -2.07228800 & 0.39620700 \\ \mathrm{H} & -4.32886400 & -2.96823400 & -1.13984600 \\ \mathrm{H} & -4.86095900 & -1.27172800 & -1.11786600 \\ & & & \end{array}$




$\begin{array}{lrrr}\mathrm{C} & -1.70691200 & -2.68929800 & -0.55910300 \\ \mathrm{H} & -0.65936100 & -2.34303600 & -0.62191100 \\ \mathrm{H} & -1.83429600 & -3.54725100 & -1.24236100 \\ \mathrm{H} & -1.88623200 & -3.05538500 & 0.46604100 \\ \mathrm{C} & -3.33317800 & 1.37011600 & -0.69571900 \\ \mathrm{H} & -2.79745000 & 2.29889000 & -0.43111700 \\ \mathrm{C} & -4.69893600 & 1.40148700 & 0.01163600 \\ \mathrm{H} & -5.29975000 & 0.50233300 & -0.19568700 \\ \mathrm{H} & -5.27685800 & 2.27469600 & -0.34123900 \\ \mathrm{H} & -4.59508000 & 1.49452200 & 1.10465400 \\ \mathrm{C} & -3.46735200 & 1.33045500 & -2.22791000 \\ \mathrm{H} & -2.47973200 & 1.31493300 & -2.71975000 \\ \mathrm{H} & -4.01207100 & 2.22209400 & -2.58409600 \\ \mathrm{H} & -4.03020500 & 0.44283500 & -2.56422600 \\ \mathrm{C} & 3.15438700 & -1.46342200 & -0.89495600 \\ \mathrm{H} & 4.18011700 & -1.50727200 & -0.48183200 \\ \mathrm{C} & 2.45841200 & -2.80964600 & -0.63579900 \\ \mathrm{H} & 2.45087200 & -3.07850200 & 0.43327900 \\ \mathrm{H} & 2.97816500 & -3.61836200 & -1.17970400 \\ \mathrm{H} & 1.41313200 & -2.78296500 & -0.98901700 \\ \mathrm{C} & 3.22315200 & -1.16302900 & -2.40063300 \\ \mathrm{H} & 2.21217900 & -0.97534100 & -2.80306800 \\ \mathrm{H} & 3.65739200 & -2.02211900 & -2.94246100 \\ \mathrm{H} & 3.84526900 & -0.28038900 & -2.61898500 \\ \mathrm{C} & 3.37066100 & 1.41633200 & -0.07382000 \\ \mathrm{H} & 3.01742000 & 1.98817900 & 0.80430400 \\ \mathrm{C} & 4.86683000 & 1.10814300 & 0.07663200 \\ \mathrm{H} & 5.44374200 & 2.04697600 & 0.15801300 \\ \mathrm{H} & 5.25693500 & 0.55942900 & -0.79810000 \\ \mathrm{H} & 5.07899900 & 0.50564100 & 0.97640000 \\ \mathrm{C} & 3.04804300 & 2.27077500 & -1.31076800 \\ \mathrm{H} & 3.27793500 & 1.74821600 & -2.25413800 \\ \mathrm{H} & 3.64407600 & 3.20137800 & -1.29234800 \\ \mathrm{H} & 1.97886100 & 2.53396600 & -1.29746600 \\ \mathrm{O} & 0.39757200 & 2.05244800 & 0.62948700 \\ \mathrm{C} & -0.57400600 & 3.04029300 & 0.78043600 \\ \mathrm{H} & -0.16787900 & 3.93361200 & 1.31365700 \\ \mathrm{H} & -0.97578300 & 3.41967300 & -0.19178900 \\ \mathrm{H} & -1.46694300 & 2.71457100 & 1.37478400\end{array}$

$\left({ }^{\mathrm{iPr} P N}{ }^{\mathrm{H}} \mathrm{P}\right) \mathrm{Fe}(\mathrm{H})\left(\mathrm{OCH}_{3}\right)(9$ no CO quintet $)$ BP86* $^{*} \quad \mathrm{G}_{\mathrm{THF}}=-1009222.875 \mathrm{kcal} / \mathrm{mol}$

$\begin{array}{lllll}\mathrm{Fe} & 0.05532800 & 0.20692700 & -0.49284200\end{array}$

$\mathrm{H} \quad 0.07030500 \quad-0.59882900-1.97930200$

$\begin{array}{llll}\mathrm{P} & -2.51201300 & -0.02925300 & -0.11901300\end{array}$

$\begin{array}{llll}\mathrm{P} & 2.59482600 & -0.13463800 & 0.03942600\end{array}$

$\begin{array}{llll}\mathrm{N} & -0.02504400 & -0.79386900 & 1.62431000\end{array}$

$\begin{array}{llll}\mathrm{H} & 0.01025700 & 0.05246400 & 2.21386700\end{array}$

$\begin{array}{llll}\mathrm{C} & -2.53016700 & -0.64885900 & 1.65340300\end{array}$

$\mathrm{H} \quad-2.52064900 \quad 0.24210200 \quad 2.30923000$

$\begin{array}{llll}\mathrm{H} & -3.44349500 & -1.21754000 & 1.90428900\end{array}$

C $\quad-1.29016500 \quad-1.50924000 \quad 1.94770500$ 


\begin{tabular}{|c|c|c|c|}
\hline $\mathrm{H}$ & -1.29708100 & -1.81949600 & 3.01403100 \\
\hline $\mathrm{H}$ & -1.30164600 & -2.43261600 & 1.34353600 \\
\hline $\mathrm{C}$ & 1.15814500 & -1.62965700 & 1.96808400 \\
\hline $\mathrm{H}$ & 1.12123400 & -2.52168900 & 1.31834400 \\
\hline $\mathrm{H}$ & 1.08797700 & -1.98833600 & 3.01692700 \\
\hline $\mathrm{C}$ & 2.47638700 & -0.86546100 & 1.77184300 \\
\hline $\mathrm{H}$ & 3.32736200 & -1.53120300 & 2.00335400 \\
\hline $\mathrm{H}$ & 2.52464700 & -0.02471400 & 2.48951300 \\
\hline $\mathrm{C}$ & -3.54416100 & -1.28659000 & -1.09567900 \\
\hline $\mathrm{H}$ & -3.52810200 & -0.86382900 & -2.11971500 \\
\hline $\mathrm{C}$ & -5.01113200 & -1.49048100 & -0.67243200 \\
\hline $\mathrm{H}$ & -5.09473800 & -1.80051800 & 0.38468900 \\
\hline $\mathrm{H}$ & -5.46763200 & -2.29137200 & -1.28432800 \\
\hline $\mathrm{H}$ & -5.61921900 & -0.58299200 & -0.81177500 \\
\hline $\mathrm{C}$ & -2.79624100 & -2.63768300 & -1.14143200 \\
\hline $\mathrm{H}$ & -1.73377500 & -2.50907900 & -1.41136300 \\
\hline $\mathrm{H}$ & -3.26534400 & -3.30140400 & -1.89036600 \\
\hline $\mathrm{H}$ & -2.85049500 & -3.15784200 & -0.16804600 \\
\hline $\mathrm{C}$ & -3.50607200 & 1.58349100 & -0.04734000 \\
\hline $\mathrm{H}$ & -2.74219700 & 2.28345000 & 0.34373400 \\
\hline $\mathrm{C}$ & -4.72696600 & 1.65111300 & 0.89210000 \\
\hline $\mathrm{H}$ & -5.55889100 & 1.01864900 & 0.54263600 \\
\hline $\mathrm{H}$ & -5.09886200 & 2.69220300 & 0.93441600 \\
\hline $\mathrm{H}$ & -4.48234100 & 1.34933000 & 1.92428100 \\
\hline $\mathrm{C}$ & -3.85985400 & 2.04183300 & -1.47800200 \\
\hline $\mathrm{H}$ & -2.98014600 & 2.02615600 & -2.14411200 \\
\hline $\mathrm{H}$ & -4.25119700 & 3.07498700 & -1.45802500 \\
\hline $\mathrm{H}$ & -4.64064100 & 1.40276000 & -1.92738000 \\
\hline $\mathrm{C}$ & 3.75501800 & -1.35769300 & -0.83177400 \\
\hline $\mathrm{H}$ & 4.70200300 & -1.38294100 & -0.25789300 \\
\hline $\mathrm{C}$ & 3.14881800 & -2.77615800 & -0.83137300 \\
\hline $\mathrm{H}$ & 3.03286600 & -3.18498800 & 0.18647000 \\
\hline $\mathrm{H}$ & 3.81271700 & -3.46431500 & -1.38619500 \\
\hline $\mathrm{H}$ & 2.16114100 & -2.79126600 & -1.32572900 \\
\hline $\mathrm{C}$ & 4.05000900 & -0.89760500 & -2.27341800 \\
\hline $\mathrm{H}$ & 3.11627800 & -0.79103900 & -2.85400600 \\
\hline $\mathrm{H}$ & 4.68334700 & -1.64535900 & -2.78536700 \\
\hline $\mathrm{H}$ & 4.58353500 & 0.06634200 & -2.30667900 \\
\hline $\mathrm{C}$ & 3.64045500 & 1.41448600 & 0.37779700 \\
\hline $\mathrm{H}$ & 3.09656200 & 1.86059700 & 1.23468700 \\
\hline $\mathrm{C}$ & 5.09319200 & 1.15176400 & 0.81675900 \\
\hline $\mathrm{H}$ & 5.57161500 & 2.10119000 & 1.12135600 \\
\hline $\mathrm{H}$ & 5.69630400 & 0.73284500 & -0.00802600 \\
\hline $\mathrm{H}$ & 5.15610300 & 0.45742900 & 1.67263700 \\
\hline $\mathrm{C}$ & 3.55663100 & 2.42359000 & -0.78637800 \\
\hline $\mathrm{H}$ & 4.10310200 & 2.06931900 & -1.67748800 \\
\hline $\mathrm{H}$ & 4.01269100 & 3.38447600 & -0.48398500 \\
\hline $\mathrm{H}$ & 2.50651800 & 2.60528700 & -1.07237400 \\
\hline $\mathrm{O}$ & 0.09292300 & 2.09656200 & -0.50710600 \\
\hline $\mathrm{C}$ & 0.06578200 & 2.95137500 & 0.61025900 \\
\hline $\mathrm{H}$ & -0.51697600 & 3.87366000 & 0.39081000 \\
\hline
\end{tabular}


$\begin{array}{llll}\mathrm{H} & -0.39864000 & 2.48313800 & 1.50974500\end{array}$

$\begin{array}{llll}\mathrm{H} & 1.08863200 & 3.27846800 & 0.90728200\end{array}$ 
$X V$. Discussion on Dissociative CO Loss from ${ }^{i P r} P N^{H} P$ Supported Fe complexes

In Table S8 below we report the free energies of $\mathrm{Fe}-\mathrm{CO}$ bond cleavage from $\mathbf{2}, \mathbf{5 - T H F}, \mathbf{6}, \mathbf{9}$, and 10 to give free $\mathrm{CO}$ and the resulting coordinatively unsaturated complex in the singlet, triplet, and quintet states. The results reveal large differences in the relative energies for $\mathrm{CO}$ dissociation for the triplet and quintet states for similar compounds. For example, for 5-THF the formation of a CO dissociated complex in the triplet state is $28 \mathrm{kcal} / \mathrm{mol}$ more favorable than the formation of a complex in the singlet state, whereas for $\mathbf{2}$ the formation of a $\mathrm{CO}$ dissociated complex in the singlet state is $0.9 \mathrm{kcal} / \mathrm{mol}$ more favorable. Hence, between the complexes that arise from CO dissociation of $\mathbf{2}$ and $\mathbf{5}$ there is a $29 \mathrm{kcal} / \mathrm{mol}$ relative difference in energy between the singlet and triplet states, which is chemically unreasonable. Given the disparity in the free energy change observed for similar compounds, we selected 5-THF and $\mathbf{9}$ for further investigation. Specifically, we evaluated different functionals for the dissociation of CO. The functionals M06, M06L, ${ }^{21}$ B3LYP*,22 and BP86*23 (*denotes the use of an empirical dispersion correction ${ }^{24}$ ) were utilized. The functional identity was found to have a large impact on the difference between the singlet, triplet, and quintet states for the free energy of CO loss (Table S9). For instance, there was a staggering $147 \mathrm{kcal} / \mathrm{mol}$ in energy between functionals for the quintet states for $\mathbf{5 - T H F}$ and $135 \mathrm{kcal} / \mathrm{mol}$ for $\mathbf{9}$. For triplet states the energy differences were smaller but still approximately $25-30 \mathrm{kcal} / \mathrm{mol}$. We note that this problem of different functionals giving large differences in energy is not a unique problem for the present case, as accurate computation of spin state splitting energies for iron complexes has been shown to be challenging for approximate density functionals and even for higher level of theories such as multiconfigurational approaches (e.g. CASSCF, CASPT2, NEVPT2). ${ }^{25}$ 


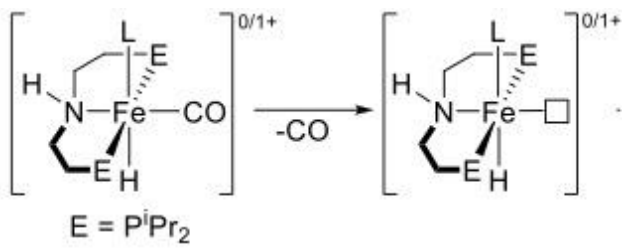

\begin{tabular}{ccccc} 
& & \multicolumn{3}{c}{ Free Energy Change $(\Delta \mathbf{G}, \mathbf{k c a l} / \mathbf{m o l})$} \\
Complex & $\mathbf{L}$ & Singlet & Triplet & Quintet \\
\hline $\mathbf{2}$ & $\mathrm{H}$ & +57.8 & +58.7 & -- \\
$\mathbf{5 - T H F}$ & $\mathrm{THF}$ & +41.8 & +13.8 & +3.2 \\
$\mathbf{6}$ & $\mathrm{PF}_{6}$ & +39.8 & +33.8 & -- \\
$\mathbf{9}$ & $\mathrm{OMe}$ & +37.4 & +15.7 & -8.5 \\
$\mathbf{1 0}$ & $\mathrm{OC}(\mathrm{H}) \mathrm{O}$ & +57.9 & +32.0 & +14.3 \\
\hline
\end{tabular}

Table S8: Free energies of $\mathrm{Fe}-\mathrm{CO}$ bond cleavage to give a coordinatively unsaturated complex singlet, triplet, and quintet states and free CO. A converged quintet state for the products of $\mathbf{2}$ and $\mathbf{6}$ could not be found.

\begin{tabular}{ccccc} 
& & \multicolumn{3}{c}{ Free Energy Change $(\Delta \mathbf{G}, \mathbf{k c a l} / \mathbf{m o l})$} \\
Complex & Functional & Singlet & Triplet & Quintet \\
\hline \multirow{5}{*}{5 5-THF } & M06 & +41.8 & +13.8 & +3.2 \\
& M06L & +45.4 & +37.1 & +38.2 \\
& B3LYP* & +32.5 & -- & - \\
& BP86* & +50.3 & +45.4 & +150.0 \\
& M06 & +37.4 & +15.7 & -8.5 \\
9 & M06L & +41.4 & +33.6 & +23.2 \\
& B3LYP* & +36.1 & +19.8 & +87.6 \\
& BP86* & +39.6 & +40.0 & +127.2 \\
\hline
\end{tabular}

Table S9: Free energies of $\mathrm{Fe}-\mathrm{CO}$ bond cleavage from 5-THF or 9 to give free $\mathrm{CO}$ and a coordinatively unsaturated complex in either the singlet, triplet, or quintet state using various functionals. A converged triplet or quintet state for the product of 5-THF with the BP86* functional could not be found.

One explanation for the large differences in functional is that multiconfiguration states are present. To address this issue, we performed CASSCF calculations to investigate the nature of the singlet, triplet and quintet wavefunctions of CO dissociation product complexes of 5-THF using a 10 electron 7 orbital $(10,7)$ active space featuring Fe 3d and relevant ligand orbitals (Figures S67-S69). The weights of the largest CI coefficients in $(10,7)$ calculations (Figure S67-S69, Table S10-S12) indicate no significant multiconfigurational character (except for singlet wavefunction on quintet geometry, Table S12) and expanding the active space to $(10,12)$ to include a second d-shell $(4 d)$ orbitals did not lead to any significant changes. 
Figure S67. Plots of molecular orbitals (top and side views) in active space of CAS $(10,7)$ calculation on singlet $(S=0)$ geometry of the product complex formed upon $\mathrm{CO}$ dissociation from 5-THF. Color code: $\mathrm{Fe}$, violet; $\mathrm{C}$, gray; $\mathrm{N}$, blue; $\mathrm{O}$, red; $\mathrm{P}$, orange; $\mathrm{H}$, white.

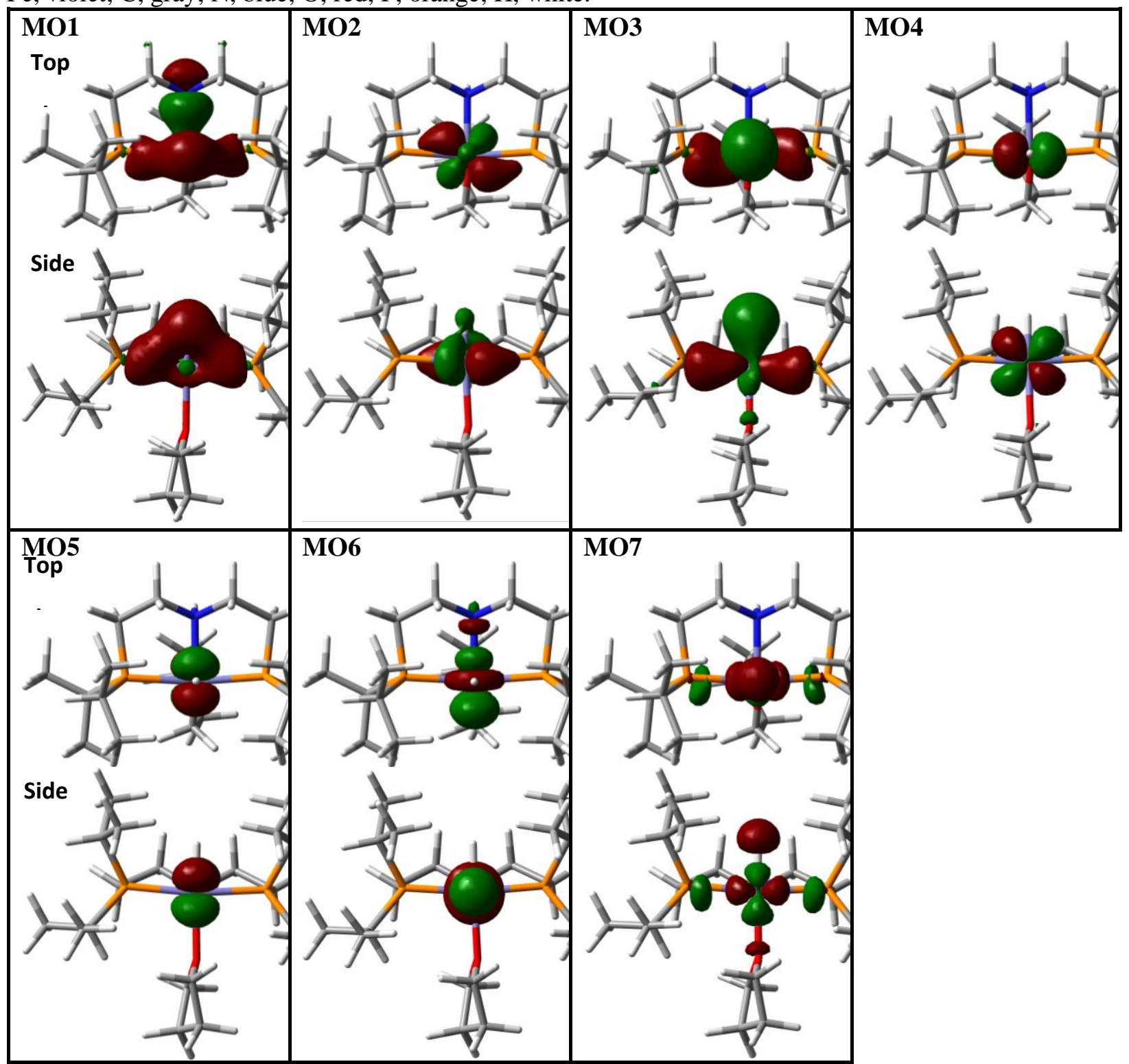

Table S10. Weights of contributing configurations and active space occupation patterns for CAS $(10,7)$ calculation on singlet $(S=0)$ geometry of the product complex formed upon CO dissociation from 5-THF.

\begin{tabular}{|l|l|l|}
\hline Singlet $(\mathbf{S}=\mathbf{0})$ & Triplet $(\mathbf{S}=\mathbf{1})$ & Quintet $(\mathbf{S}=\mathbf{2})$ \\
\hline $0.94152: 2222200$ & $0.93559: 2222110$ & $0.99766: 2221111$ \\
$0.01591: 2222020$ & $0.03252: 2211220$ & \\
$0.01209: 2220220$ & $0.00812: 2211211$ & \\
$0.00831: 2202220$ & $0.00674: 2122111$ & \\
$0.00480: 2222002$ & $0.00543: 2202112$ & \\
$0.00382: 2022202$ & $0.00501: 2022112$ & \\
$0.00358: 2202202$ & $0.00341: 2220112$ & \\
$0.00252: 1122211$ & & \\
\hline
\end{tabular}


Figure S68. Plots of molecular orbitals (top and side views) in active space of CAS $(10,7)$ calculation on triplet $(\mathrm{S}=1)$ geometry of the product complex formed upon $\mathrm{CO}$ dissociation from 5-THF. Color code: Fe, violet; $\mathrm{C}$, gray; $\mathrm{N}$, blue; $\mathrm{O}$, red; $\mathrm{P}$, orange; $\mathrm{H}$, white.

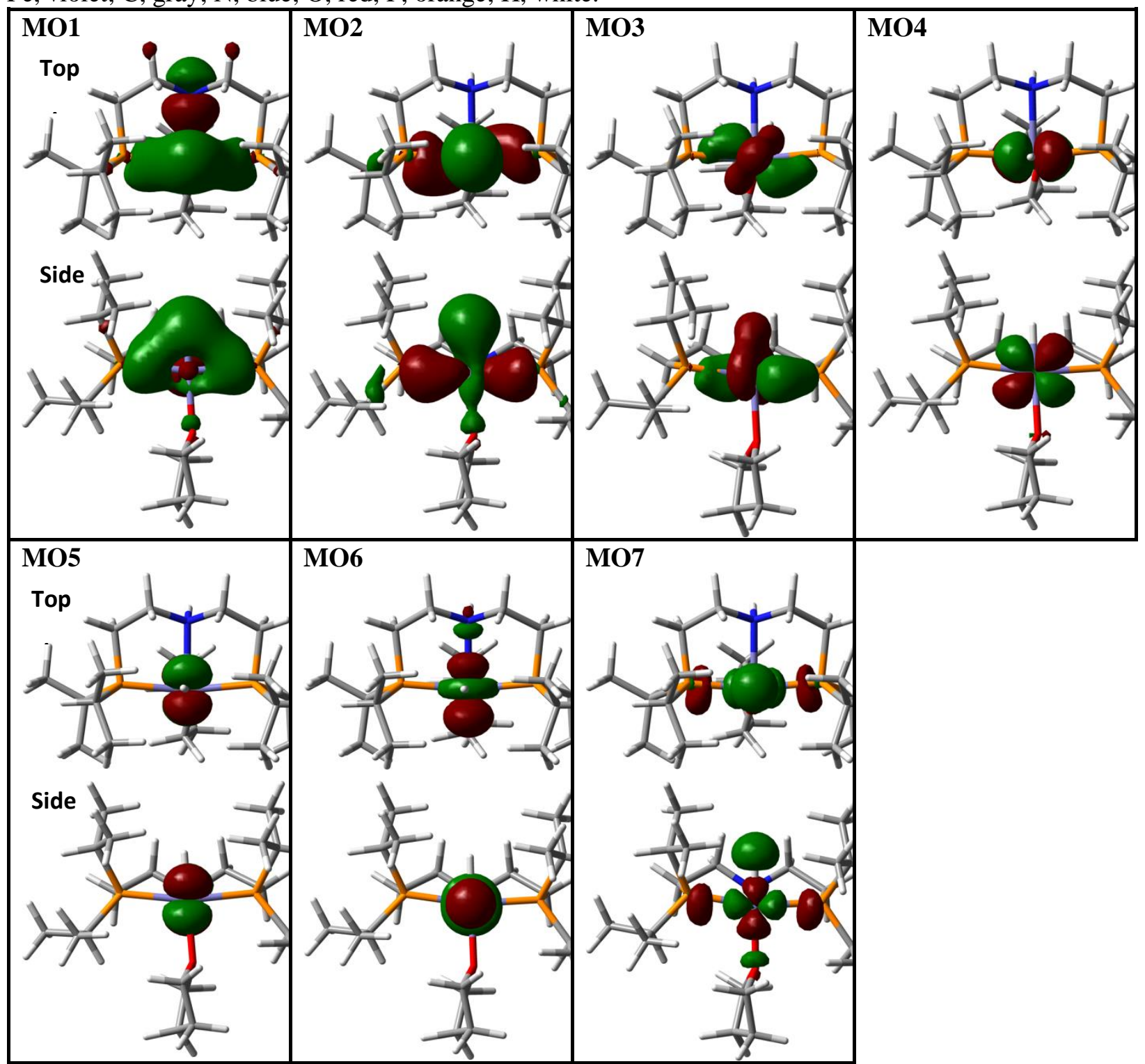

Table S11. Weights of contributing configurations and active space occupation patterns for CAS $(10,7)$ calculation on triplet $(\mathrm{S}=0)$ geometry of the product complex formed upon $\mathrm{CO}$ dissociation from 5-THF.

\begin{tabular}{|c|c|c|}
\hline Singlet $(\mathbf{S}=\mathbf{0})$ & Triplet $(\mathbf{S}=\mathbf{1})$ & Quintet $(\mathbf{S}=\mathbf{2})$ \\
\hline $0.92739: 2222200$ & $0.92525: 2222110$ & $0.99687: 2221111$ \\
$0.02486: 2222020$ & $0.04154: 2211220$ & \\
$0.01509: 2220220$ & $0.00847: 2211211$ & \\
$0.01063: 2202220$ & $0.00601: 2122111$ & \\
$0.00415: 2222002$ & $0.00548: 2202112$ & \\
$0.00403: 2022202$ & $0.00483: 2022112$ & \\
$0.00340: 2202202$ & $0.00312: 2220112$ & \\
$0.00339: 2211121$ & & \\
\hline
\end{tabular}


Figure S69. Plots of molecular orbitals (top and side views) in active space of CAS (10,7) calculation on quintet $(S=2)$ geometry of the product complex formed upon $\mathrm{CO}$ dissociation from 5-THF. Color code: Fe, violet; $\mathrm{C}$, gray; $\mathrm{N}$, blue; $\mathrm{O}$, red; $\mathrm{P}$, orange; $\mathrm{H}$, white.

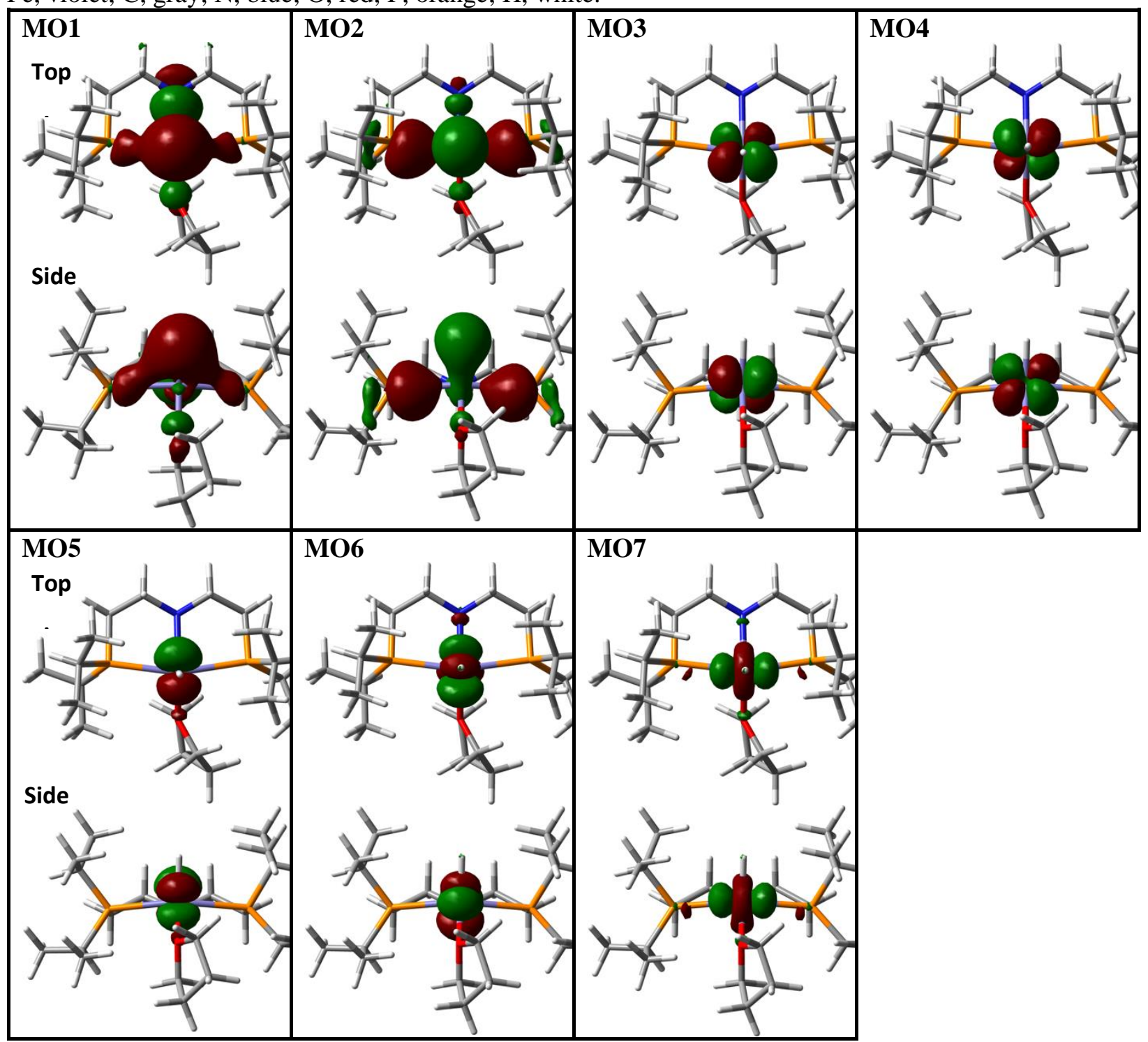

Table S12. Weights of contributing configurations and active space occupation patterns for CAS $(10,7)$ calculation on quintet $(S=2)$ geometry of the product complex formed upon CO dissociation from 5-THF.

\begin{tabular}{|c|c|c|}
\hline Singlet $(\mathbf{S}=\mathbf{0})$ & Triplet $(\mathbf{S}=\mathbf{1})$ & Quintet $(\mathbf{S}=\mathbf{2})$ \\
\hline $0.8554: 2222200$ & $0.92694: 2222110$ & $0.99920: 2221111$ \\
$0.09110: 2222020$ & $0.03972: 2211220$ & \\
$0.00941: 2220202$ & $0.01219: 2220112$ & \\
$0.00862: 2202220$ & $0.01059: 2202112$ & \\
$0.00802: 2202202$ & $0.00391: 2122111$ & \\
$0.00696: 2222002$ & & \\
$0.00662: 2220220$ & & \\
$0.00306: 2220022$ & & \\
$0.00265: 2202121$ & & \\
\hline
\end{tabular}


Given the mostly single configurational character of the wavefunctions, we next performed DLPNO$\operatorname{CCD}\left(\mathrm{T}_{1}\right)$ (DLPNO-CCSD(T) with full iterative triples scheme) calculations using second-order DouglasKroll-Hess Hamiltonian (DKH2) to include scalar relativistic effects, which has recently been shown to be as effective an approach in reproducing spin-state splittings quite accurately for iron complexes compared to the canonical $\operatorname{CCSD}(\mathrm{T})$ results. $^{25 c}$ Only the triple- $\zeta$ DKH-def2-TZVPP basis sets are reasonable for DLPNO-CCD $\left(\mathrm{T}_{1}\right)$ calculations due to the size of the systems investigated in the present work and basis set convergence could not be probed. However, this is not expected to affect our conclusions since triple- $\zeta$ basis sets seem to lie on average within $4-5 \mathrm{kcal} / \mathrm{mol}$ of the converged results. Only the singlet and quintet states for CO dissociation from 5-THF were calculated due to the high computational cost and the fact that at the lower level of theory the quintet state is the ground state. The computed energetics indicate that $\mathrm{CO}$ dissociation from $\mathbf{5 - T H F}$ is quite unlikely $(\Delta \mathrm{G}=27.6 \mathrm{kcal} / \mathrm{mol})$ at this higher level of theory. Interestingly, with this new computational procedure the hybrid B3LYP and meta-hybrid M06 functional exhibit relatively similar energetics compared to DLPNO-CCD $\left(\mathrm{T}_{1}\right)$ level. Overall, although there is significant variation in the computed energetics for the $\mathrm{CO}$ dissociation step depending on the choice of different approximate density functional, the calculations at the DLPNO-CCD $\left(\mathrm{T}_{1}\right)$ level of theory (along with hybrid functionals) suggest that $\mathrm{CO}$ dissociation is unlikely for 5-THF. Given the high energy for CO dissociation from 5-THF, this is also probably translatable to the other intermediates that could potentially form in catalysis.

Table S13. Computed free energy changes $(\Delta \mathrm{G})$ in $\mathrm{kcal} / \mathrm{mol}$ at different level of theories for $\mathrm{CO}$ dissociation from 5-THF to generate closed-shell singlet and quintet product complexes. The structures are optimized at M06-L level of theory and single point calculations were performed at different levels of theory using DKH2 approach and DKH-def2-TZVPP basis set (see below for further details).

\begin{tabular}{|c|c|c|}
\hline & \multicolumn{2}{|c|}{$\Delta \mathbf{G ~ ( k c a l / m o l )}$} \\
\hline Level of Theory & Singlet Product & Quintet Product \\
\hline BP86-D3BJ & 57.5 & 71.6 \\
\hline M06-L & 49.7 & 44.1 \\
\hline B3LYP-D3BJ & 37.3 & 30.5 \\
\hline M06 & 40.3 & 18.7 \\
\hline DLPNO-CCSD(T $\left.{ }_{1}\right)$ & 41.0 & 27.6 \\
\hline
\end{tabular}


Procedure for Multiconfigurational calculations. Multireference calculations based on the $\mathrm{CASSCF}^{26}$ methods were performed for product complexes formed upon CO dissociation from 5-THF to inspect the nature of the singlet, triplet, and quintet wavefunctions. The calculations were performed at the M06-L optimized geometries for singlet, triplet, and quintet structures using the ORCA program package. ${ }^{27}$ Triple- $\zeta$ quality basis sets (def2TZVP for all atoms ${ }^{28}$ ) with [17s11p7d1f $\left.\mid 6 s 4 p 4 d 1 f\right]$ contraction for Ru, [14s9p3d1f | 5s5p2d1f] contraction for $\mathrm{P},[11 \mathrm{~s} 6 \mathrm{p} 2 \mathrm{~d} 1 \mathrm{f} \mid 5 \mathrm{~s} 3 \mathrm{p} 2 \mathrm{~d} 1 \mathrm{f}]$ contraction for $\mathrm{C}, \mathrm{N}$ and $\mathrm{O}$, and [5s1p | 3s1] contraction for $\mathrm{H}$ have been employed together with the RIJK ${ }^{29}$ approximation in CASSCF calculations. We chose an active space containing ten electrons in seven orbitals corresponding to linear combinations of five of the $3 \mathrm{~d}$ orbitals of Fe and the valence orbitals of the selected set of ligand atoms.

Procedure for Coupled-cluster and DFT benchmark calculations. Domain-based pair natural orbital coupled cluster with singles, doubles, and perturbative triples (DLPNO-CCSD $(\mathrm{T}))^{30}$ method has been employed to study the energetics associated with CO dissociation from 5-THF complex. A recent implementation of full iterative triples (denoted DLPNO-CCSD $\left(\mathrm{T}_{1}\right)$ ) of this approach which was shown to mirror the accuracy of canonical CCSD $(\mathrm{T})$ has been utilized in the present study. All DLPNO-CCSD $\left(\mathrm{T}_{1}\right)$ and DFT single point calculations utilized the second-order Douglas-Kroll-Hess Hamiltonian (DKH2) ${ }^{31}$ to include scalar relativistic effects, SMD solvation model for THF as the solvent and the DKH-def2-TZVPP ${ }^{28 b}$ basis set. The $\mathrm{RI}^{32}$ (for BP86 and M06-L) and RIJCOSX ${ }^{33}$ (for B3LYP, M06 and DLPNO-CCSD(T 1 )) approximations were used together with relevant fitting basis sets. ${ }^{34}$ Atom-pairwise dispersion correction to the DFT energies with Becke-Johnson damping has been applied for BP86 and B3LYP density functionals. ${ }^{35}$ 
Given the ambiguity in the calculations several experiments were performed to further investigate $\mathrm{CO}$ dissociation.

Initially, in a glovebox, to a J. Young NMR tube were added $\mathbf{1}(1.4 \mathrm{mg}, 3.6 \mu \mathrm{mol})$, toluene- $\mathrm{d}_{8}(0.600 \mathrm{~mL})$, and formic acid ( $14 \mu \mathrm{L}, 0.36 \mathrm{mmol})$. The reaction color turned bright yellow upon addition of formic acid, and gas formation was observed. The reaction mixture was frozen in liquid $\mathrm{N}_{2}$, degassed, and sealed under vacuum. The solution color quickly bleached to colorless and an off-white precipitate formed. Spectroscopic data taken after thirty minutes is shown in Figure S70. Only decomposition product $\mathbf{4}$ is observed. This indicates that under these conditions, the pathway for CO ligand transfer must be easily accessible and occur rapidly at room temperature.

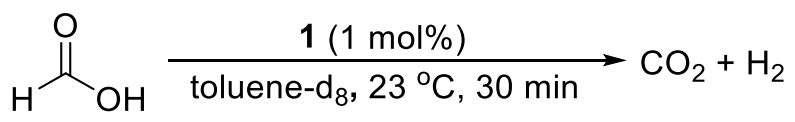

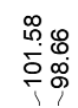

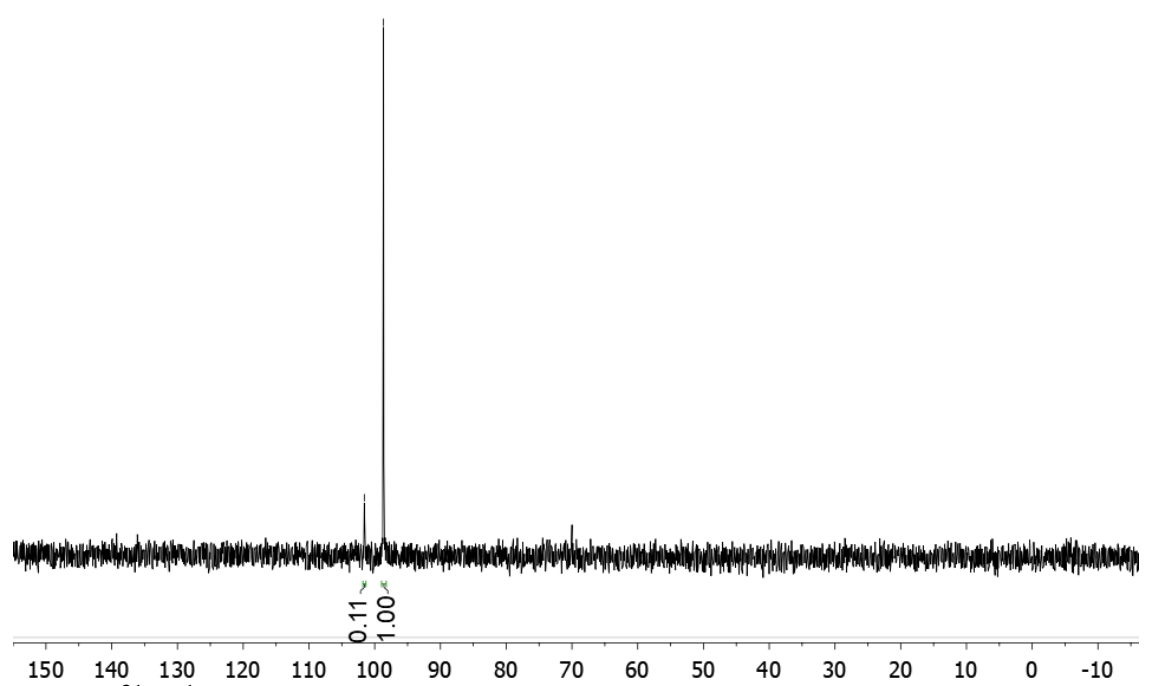

Figure S70. In situ ${ }^{31} \mathrm{P}\left\{{ }^{1} \mathrm{H}\right\}$ NMR of formic acid dehydrogenation using 1 in toluene- $\mathrm{d}_{8}$ after thirty minutes at room temperature. 4 is present as two isomers at 98.66 and $101.58 \mathrm{ppm}$.

To further understand the tendency of ${ }^{\mathrm{iPr}} \mathrm{PN}^{\mathrm{H}} \mathrm{P}$ supported $\mathrm{Fe}$ complexes to dissociate $\mathrm{CO}$, we studied the rate at which the $\mathrm{CO}$ ligand in $\left[\left({ }^{\mathrm{iPr}} \mathrm{PN}{ }^{\mathrm{H}} \mathrm{P}\right) \mathrm{Fe}(\mathrm{CO})_{2} \mathrm{H}\right]^{+}$(4) undergoes exchange with ${ }^{13} \mathrm{CO}$ using NMR spectroscopy. The reason this compound was selected is because it is rare example of a stable cationic Fe 
complex supported by the ${ }^{\mathrm{iPr}} \mathrm{PN}^{\mathrm{H}} \mathrm{P}$ and the presence of two $\mathrm{CO}$ ligands presumably means that it is much more likely to lose $\mathrm{CO}$ than catalytically relevant intermediates such as $\mathbf{2}, \mathbf{5}-\mathbf{T H F}, \mathbf{6}, \mathbf{9}$, and 10, which are not stable. To a J. Young tube were added $\left.\left[{ }^{\mathrm{iPr} P N}{ }^{\mathrm{H} P}\right) \mathrm{Fe}(\mathrm{CO}){ }_{2} \mathrm{H}\right][\mathrm{OTf}]($ 4-OTf $)(6.2 \mathrm{mg}, 0.011 \mathrm{mmol})$ and $500 \mu \mathrm{L}$ of benzene- $d_{6}$. The sample was analyzed by ${ }^{1} \mathrm{H},{ }^{31} \mathrm{P}\left\{{ }^{1} \mathrm{H}\right\}$, and ${ }^{13} \mathrm{C}\left\{{ }^{1} \mathrm{H}\right\}$ NMR spectroscopy and the integration of the natural abundance $\mathrm{Fe}^{13}{ }^{13} \mathrm{CO}$ resonances determined versus an internal standard of mesitylene. The sample was then degassed and treated with 400 torr of ${ }^{13} \mathrm{CO}$ and allowed to stand at ambient temperature for 24 hours. The sample was again analyzed by ${ }^{1} \mathrm{H},{ }^{31} \mathrm{P}\left\{{ }^{1} \mathrm{H}\right\}$, and ${ }^{13} \mathrm{C}\left\{{ }^{1} \mathrm{H}\right\}$ NMR spectroscopy. Minor ${ }^{13} \mathrm{CO}$ incorporation was evident in two resonances at 208.3 and $211.3 \mathrm{ppm}$ in the $13 \mathrm{C}$ NMR spectrum, indicating an approximately $7 \mathrm{x}$ signal growth in the peak at $208.3 \mathrm{ppm}$ and a 2x signal growth at 211.3 over the 24 hour period. Small peaks corresponding to the minor isomer of $\mathbf{4}$ also began to grow in. Spectra for this experiment are shown in Figures S71-S74.

Incorporation of ${ }^{13} \mathrm{CO}$ over this period is very minor, particularly given the high concentration of ${ }^{13} \mathrm{CO}$ relative to 4-OTf. Given the rapid rate of decomposition in the experiment shown in Figure S70 compared to the slow observed exchange of $\mathrm{CO}$, we propose that dissociative $\mathrm{CO}$ loss, while a possible mechanism for decomposition, is not the most likely pathway. We believe dimer formation, as discussed in the main text, is more plausible. 


\begin{tabular}{ll}
$\stackrel{\infty}{\infty}$ & \multirow{N}{\infty}{} \\
$\stackrel{\infty}{N}$ & $\stackrel{\sim}{1}$
\end{tabular}

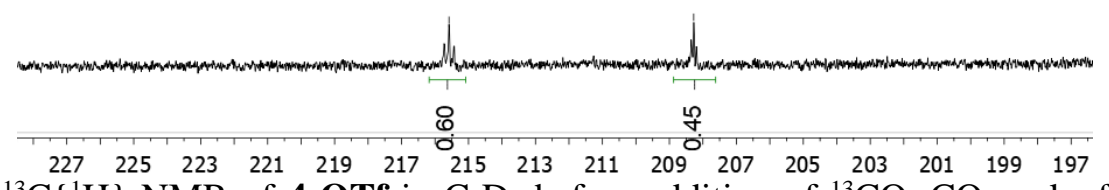

Figure S71. ${ }^{13} \mathrm{C}\left\{{ }^{1} \mathrm{H}\right\}$ NMR of 4-OTf in $\mathrm{C}_{6} \mathrm{D}_{6}$ before addition of ${ }^{13} \mathrm{CO}$. $\mathrm{CO}$ peaks for the major isomer of 4-OTf present at 215.58 and $208.27 \mathrm{ppm}$, CO peaks for the minor isomer not observed.

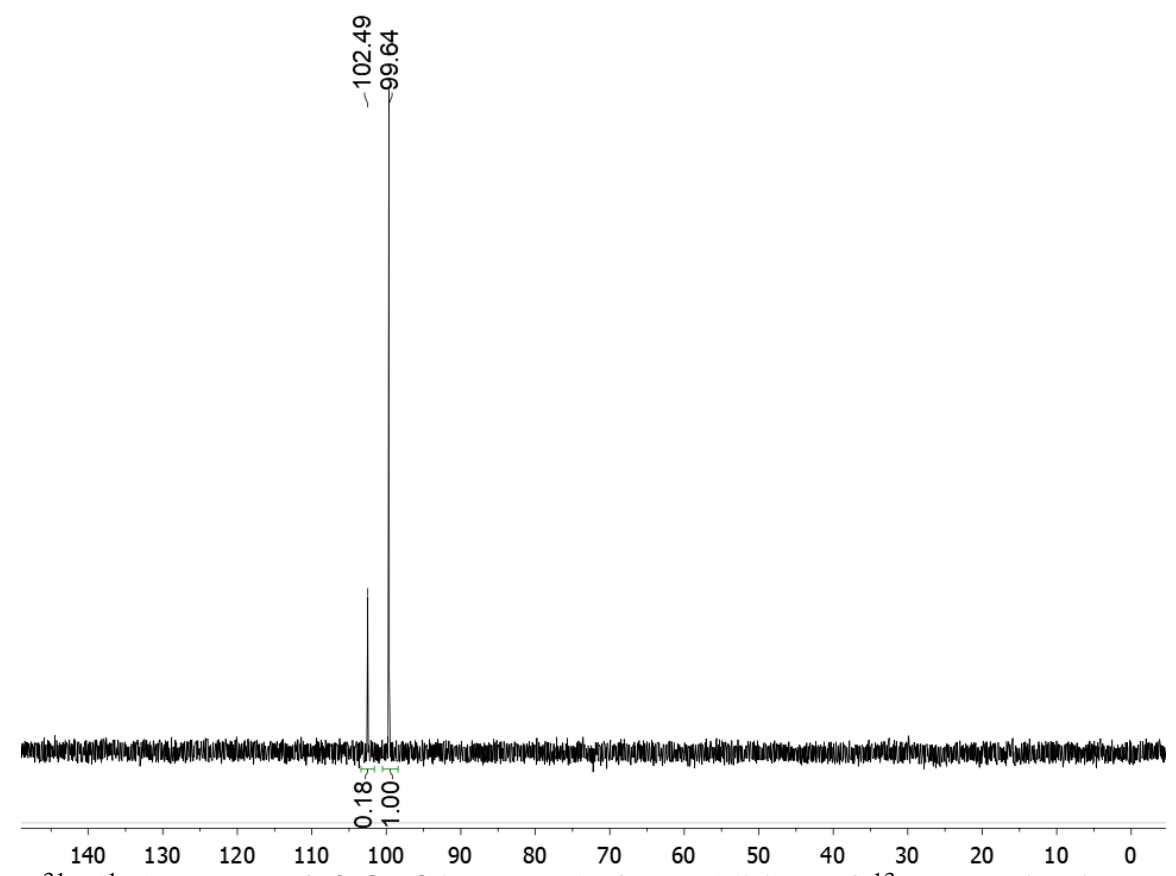

Figure S72. ${ }^{31} \mathrm{P}\left\{{ }^{1} \mathrm{H}\right\}$ NMR of 4-OTf in $\mathrm{C}_{6} \mathrm{D}_{6}$ before addition of ${ }^{13} \mathrm{CO}$. Major isomer of 4-OTf present at $99.64 \mathrm{ppm}$, minor isomer at $102.49 \mathrm{ppm}$. 


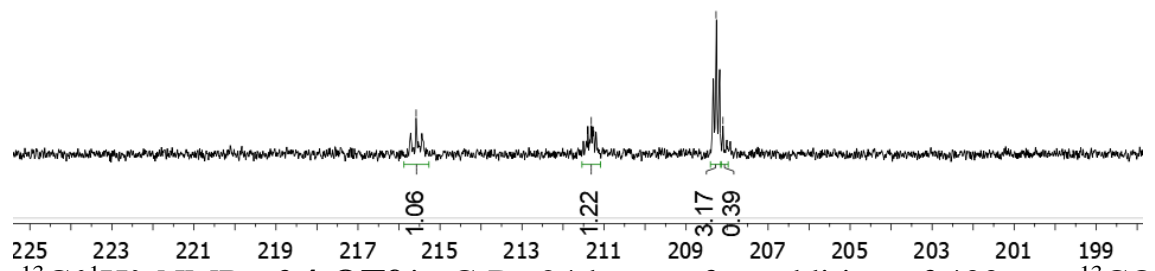

Figure S73. ${ }^{13} \mathrm{C}\left\{{ }^{12} \mathrm{H}\right\}$ NMR of 4-OTf in $\mathrm{C}_{6} \mathrm{D}_{6} 24$ hours after addition of 400 torr ${ }^{13} \mathrm{CO}$. CO peaks for the major isomer of 4-OTf present at 215.58 and 208.27 ppm, CO peaks for the minor isomer present at 211.3 and $208.1 \mathrm{ppm}$.

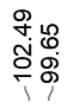

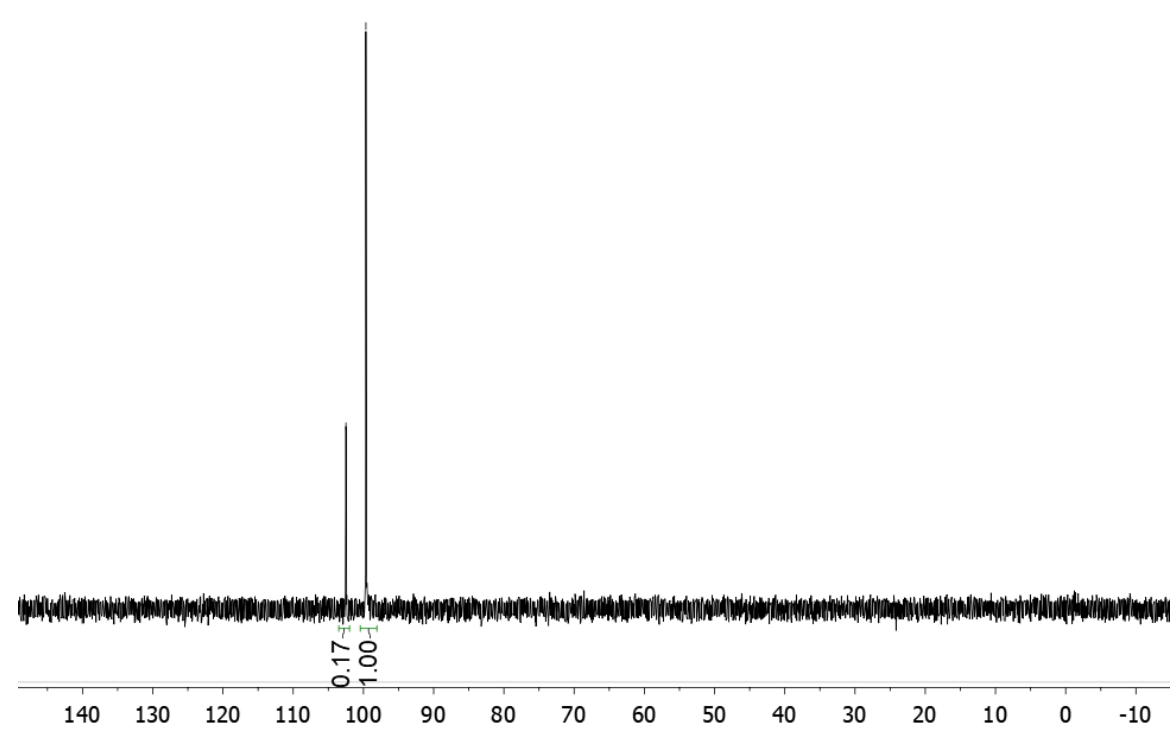

Figure S74. ${ }^{31} \mathrm{P}\left\{{ }^{1} \mathrm{H}\right\}$ NMR of 4-OTf in $\mathrm{C}_{6} \mathrm{D}_{6} 24$ hours after addition of 400 torr ${ }^{13} \mathrm{CO}$. Two isomers are still present in the same ratio, and no decomposition is observed. 
XVI. References

1. Bielinski, E. A.; Lagaditis, P. O.; Zhang, Y.; Mercado, B. Q.; Würtele, C.; Bernskoetter, W. H.; Hazari, N.; Schneider, S. Lewis Acid-Assisted Formic Acid Dehydrogenation Using a Pincer-Supported Iron Catalyst. J. Am. Chem. Soc. 2014, 136, 10234-10237.

2. Laughlin, L. J.; Coucouvanis, D. Use of $\left[\mathrm{MoFe}_{3} \mathrm{~S}_{4}\right]^{3+}$ Single Cubanes in the Catalytic Reduction of Acetylene to Ethylene and Ethane. Identification of Molybdenum and Iron Atoms as Catalytic Sites during Substrate Reduction and Implications for Nitrogenase Action. J. Am. Chem. Soc. 1995, 117, 3118-3125.

3. Brookhart, M.; Grant, B.; Volpe, A. F. $\left[\left(3,5-\left(\mathrm{CF}_{3}\right)_{2} \mathrm{C}_{6} \mathrm{H}_{3}\right)_{4} \mathrm{~B}\right]-\left[\mathrm{H}\left(\mathrm{OEt}_{2}\right)_{2}\right]^{+}$: A Convenient Reagent for Generation and Stabilization of Cationic, Highly Electrophilic Organometallic Complexes. Organometallics 1992, 11, 3920-3922.

4. Harris, R. K.; Becker, E. D.; Cabral De Menezes, S. M.; Granger, P.; Hoffman, R. E.; Zilm, K. W. Further Conventions for NMR Shielding and Chemical Shifts: (IUPAC recommendations 2008). Pure Appl. Chem. 2008, 80, 59-84.

5. Koehne, I.; Schmeier, T. J.; Bielinski, E. A.; Pan, C. J.; Lagaditis, P. O.; Bernskoetter, W. H.; Takase, M. K.; Wurtele, C.; Hazari, N.; Schneider, S. Synthesis and structure of six-coordinate iron borohydride complexes supported by PNP ligands. Inorg Chem 2014, 53, 2133-2143.

6. Morris, R. H. Dihydrogen, Dihydride and in Between: NMR and Structural Properties of Iron Group Complexes. Coord. Chem. Rev. 2008, 252, 2381-2394.

7. Smith, N. E.; Bernskoetter, W. H.; Hazari, N. The Role of Proton Shuttles in the Reversible Activation of Hydrogen via Metal-Ligand Cooperation. J. Am. Chem. Soc. 2019, 141, 17350-17360.

8. Tshepelevitsh, S.; Kütt, A.; Lõkov, M.; Kaljurand, I.; Saame, J.; Heering, A.; Plieger, P. G.; Vianello, R.; Leito, I. On the Basicity of Organic Bases in Different Media. Eur. J. Org. Chem. 2019, 2019, 67356748.

9. Bielinski, E. A.; Förster, M.; Zhang, Y.; Bernskoetter, W. H.; Hazari, N.; Holthausen, M. C. Base-Free Methanol Dehydrogenation Using a Pincer-Supported Iron Compound and Lewis Acid Co-catalyst. ACS Catal. 2015, 5, 2404-2415.

10. Sheldrick, G. M. A Short History of SHELX. Acta Cryst. 2008, A64, 112-122.

11. Coates, L.; Cao, H.; Chakoumakos, B. C.; Frontzek, M. D.; Hoffmann, C.; Kovalevsky, A. Y.; Liu, Y.; Meilleur, F.; dos Santos, A. M.; Myles, D. A. A Suite-Level Review of the Neutron Single-Crystal Diffraction Instruments at Oak Ridge National Laboratory. Rev. Sci. Instrum. 2018, 89, 092802.

12. Zikovsky, J.; Peterson, P. F.; Wang, X. P.; Frost, M.; Hoffmann, C. CrystalPlan: An ExperimentPlanning Tool for Crystallography. J. Appl. Crystallogr. 2011, 44, 418-423.

13. Schultz, A. J.; Jørgensen, M. R. V.; Wang, X.; Mikkelson, R. L.; Mikkelson, D. J.; Lynch, V. E.; Peterson, P. F.; Green, M. L.; Hoffmann, C. M. Integration of Neutron Time-of-Flight Single-Crystal Bragg Peaks in Reciprocal Space. J. Appl. Crystallogr. 2014, 47, 915-921.

14. Schultz, A. J.; Srinivasan, K.; Teller, R. G.; Williams, J. M.; Lukehart, C. Single-Crystal, Time-ofFlight, Neutron-Diffraction Structure of Hydrogen cis-Diacetyltetracarbonylrhenate, [cis$\left.(\mathrm{OC})_{4} \mathrm{Re}\left(\mathrm{CH}_{3} \mathrm{CO}\right)_{2}\right] \mathrm{H}$ : A metallaacetylacetone Molecule. J. Am. Chem. Soc. 1984, 106, 999-1003.

15. Sheldrick, G. M. SHELXT-Integrated Space-Group and Crystal-Structure Determination. Acta Crystallogr. A 2015, 71, 3-8.

16. Frisch, M. J.; Trucks, G. W.; Schlegel, H. B.; Scuseria, G. E.; Robb, M. A.; Cheeseman, J. R.; Scalmani, G.; Barone, V.; Petersson, G. A.; Nakatsuji, H.; Li, X.; Caricato, M.; Marenich, A. V.; Bloino, J.; Janesko, B. G.; Gomperts, R.; Mennucci, B.; Hratchian, H. P.; Ortiz, J. V.; Izmaylov, A. F.; Sonnenberg, J. L.; Williams; Ding, F.; Lipparini, F.; Egidi, F.; Goings, J.; Peng, B.; Petrone, A.; Henderson, T.; Ranasinghe, D.; Zakrzewski, V. G.; Gao, J.; Rega, N.; Zheng, G.; Liang, W.; Hada, M.; Ehara, M.; Toyota, K.; Fukuda, R.; Hasegawa, J.; Ishida, M.; Nakajima, T.; Honda, Y.; Kitao, O.; Nakai, H.; Vreven, T.; Throssell, K.; Montgomery Jr., J. A.; Peralta, J. E.; Ogliaro, F.; Bearpark, M. J.; Heyd, J. J.; Brothers, E. N.; Kudin, K. N.; Staroverov, V. N.; Keith, T. A.; Kobayashi, R.; Normand, J.; Raghavachari, K.; Rendell, A. P.; Burant, J. C.; Iyengar, S. S.; Tomasi, J.; Cossi, M.; Millam, J. M.; Klene, M.; Adamo, C.; Cammi, R.; Ochterski, J. W.; Martin, R. L.; Morokuma, K.; Farkas, O.; Foresman, J. B.; Fox, D. J. Wallingford, CT, 2016. 
17. Zhao, Y.; Truhlar, D. G. The M06 Suite of Density Functionals for Main Group Thermochemistry, Thermochemical Kinetics, Noncovalent Interactions, Excited States, and Transition Elements: Two New Functionals and Systematic Testing of Four M06-Class Functionals and 12 Other Functionals. Theor. Chem. Acc. 2008, 120, 215-241.

18. Artús Suàrez, L.; Culakova, Z.; Balcells, D.; Bernskoetter, W. H.; Eisenstein, O.; Goldberg, K. I.; Hazari, N.; Tilset, M.; Nova, A. The Key Role of the Hemiaminal Intermediate in the Iron-Catalyzed Deaminative Hydrogenation of Amides. ACS Catal. 2018, 8, 8751-8762.

19. Hay, P. J.; Wadt, W. R. Ab Initio Effective Core Potentials for Molecular Calculations. Potentials for the Transition Metal Atoms Sc to Hg. J. Chem. Phys. 1985, 82, 270-283.

20. Francl, M. M.; Pietro, W. J.; Hehre, W. J.; Binkley, J. S.; Gordon, M. S.; DeFrees, D. J.; Pople, J. A. Self-Consistent Molecular Orbital Methods. XXIII. A Polarization-Type Basis Set for Second-Row Elements. J. Chem. Phys. 1982, 77, 3654-3665.

21. Zhao, Y.; Truhlar, D. G. A New Local Density Functional for Main-Group Thermochemistry, Transition Metal Bonding, Thermochemical Kinetics, and Noncovalent Interactions. J. Chem. Phys. 2006, 125, 194101.

22. Becke, A. D. Density-Functional Thermochemistry. III. The Role of Exact Exchange. J. Chem. Phys. 1993, 98, 5648-5652.

23. Perdew, J. P. Density-Functional Approximation for the Correlation Energy of the Inhomogeneous Electron Gas. Phys. Rev. B 1986, 33, 8822-8824.

24. Wu, Q.; Yang, W. Empirical Correction to Density Functional Theory for van der Waals Interactions. J. Chem. Phys. 2001, 116, 515-524.

25. (a) Ye, S.; Neese, F. Accurate Modeling of Spin-State Energetics in Spin-Crossover Systems with Modern Density Functional Theory. Inorg. Chem. 2010, 49, 772-774; (b) Radoń, M. Benchmarking Quantum Chemistry Methods for Spin-State Energetics of Iron Complexes Against Quantitative Experimental Data. Phys. Chem. Chem. Phys. 2019, 21, 4854-4870; (c) Flöser, B. M.; Guo, Y.; Riplinger, C.; Tuczek, F.; Neese, F. Detailed Pair Natural Orbital-Based Coupled Cluster Studies of Spin Crossover Energetics. J. Chem. Theory Comput. 2020, 16, 2224-2235.

26. Roos, B. O.; Taylor, P. R.; Sigbahn, P. E. A Complete Active Space SCF Method (CASSCF) Using a Density Matrix Formulated Super-CI Approach. Chem. Phys. 1980, 48, 157-173.

27. (a) Neese, F. The ORCA Program System. Wiley Interdiscip. Rev.: Comput. Mol. Sci. 2012, 2, 73-78; (b) Neese, F. Software Update: The ORCA Program System, Version 4.0. Wiley Interdiscip. Rev.: Comput. Mol. Sci. 2018, 8, e1327.

28. (a) Weigend, F.; Häser, M.; Patzelt, H.; Ahlrichs, R. RI-MP2: Optimized Auxiliary Basis Sets and Demonstration of Efficiency. Chem. Phys. Lett. 1998, 294, 143-152; (b) Weigend, F.; Ahlrichs, R. Balanced Basis Sets of Split Valence, Triple Zeta Valence and Quadruple Zeta Valence Quality for H to Rn: Design and Assessment of Accuracy. Phys. Chem. Chem. Phys. 2005, 7, 3297-3305.

29. (a) Weigend, F. A Fully Direct RI-HF Algorithm: Implementation, Optimised Auxiliary Basis Sets, Demonstration of Accuracy and Efficiency. Phys. Chem. Chem. Phys. 2002, 4, 4285-4291; (b) Weigend, F.; Kattannek, M.; Ahlrichs, R. Approximated Electron Repulsion Integrals: Cholesky Decomposition Versus Resolution of the Identity Methods. J. Chem. Phys. 2009, 130, 164106.

30. (a) Riplinger, C.; Sandhoefer, B.; Hansen, A.; Neese, F. Natural Triple Excitations in Local Coupled Cluster Calculations with Pair Natural Orbitals. J. Chem. Phys. 2013, 139, 134101; (b) Riplinger, C.; Neese, F. An Efficient and Near Linear Scaling Pair Natural Orbital Based Local Coupled Cluster Method. $J$. Chem. Phys. 2013, 138, 034106; (c) Saitow, M.; Becker, U.; Riplinger, C.; Valeev, E. F.; Neese, F. A New Near-Linear Scaling, Efficient and Accurate, Open-Shell Domain-Based Local Pair Natural Orbital Coupled Cluster Singles and Doubles Theory. J. Chem. Phys. 2017, 146, 164105; (d) Guo, Y.; Riplinger, C.; Becker, U.; Liakos, D. G.; Minenkov, Y.; Cavallo, L.; Neese, F. Communication: An Improved Linear Scaling Perturbative Triples Correction for the Domain Based Local Pair-Natural Orbital Based Singles and Doubles Coupled Cluster Method [DLPNO-CCSD (T)]. J. Chem. Phys. 2018, 148, 011101. 
31. (a) Heß, B. A. Relativistic Effects in Heavy-Element Chemistry. Ber. Bunsenges. Phys. Chem. 1997, 101, 1-10; (b) Wolf, A.; Reiher, M.; Hess, B. A. The Generalized Douglas-Kroll Transformation. J. Chem. Phys. 2002, 117, 9215-9226.

32. (a) Eichkorn, K.; Treutler, O.; Öhm, H.; Häser, M.; Ahlrichs, R. Auxiliary Basis Sets to Approximate Coulomb Potentials. Chem. Phys. Lett. 1995, 240, 283-290; (b) Eichkorn, K.; Weigend, F.; Treutler, O.; Ahlrichs, R. Auxiliary Basis Sets for Main Row Atoms and Transition Metals and their use to Approximate Coulomb Potentials. Theor. Chem. Acc. 1997, 97, 119-124.

33. Neese, F.; Wennmohs, F.; Hansen, A.; Becker, U. Efficient, Approximate and Parallel Hartree-Fock and Hybrid DFT Calculations. A 'Chain-of-Spheres' Algorithm for the Hartree-Fock Exchange. Chem. Phys. 2009, 356, 98-109.

34. (a) Hättig, C. Optimization of Auxiliary Basis Sets for RI-MP2 and RI-CC2 Calculations: Core-Valence and Quintuple- $\zeta$ Basis Sets for H to Ar and QZVPP Basis Sets for Li to Kr. Phys. Chem. Chem. Phys. 2005, 7, 59-66; (b) Weigend, F. Accurate Coulomb-Fitting Basis Sets for H to Rn. Phys. Chem. Chem. Phys. 2006, 8, 1057-1065.

35. Grimme, S.; Ehrlich, S.; Goerigk, L. Effect of the Damping Function in Dispersion Corrected Density Functional Theory. J. Comput. Chem. 2011, 32, 1456-1465. 